\title{
GESTÃO ESTRATÉGICA DAS INFORMAÇÕES INTERNAS NA PEQUENA EMPRESA:

\author{
ESTUDO COMPARATIVO DE CASOS EM EMPRESAS DO SETOR DE \\ SERVIÇOS (HOTELEIRO) DA REGIÃO DE BROTAS-SP
}

\begin{abstract}
Dissertação apresentada à Escola de Engenharia de São Carlos da Universidade de São Paulo, como parte dos requisitos para obtenção do título de mestre em Engenharia de Produção.
\end{abstract}

Orientador: Prof. Dr. Edmundo Escrivão Filho

\section{SÃO CARLOS}




\section{DEDICATÓRIA}

Aos meus pais Jarbas e Margarida, exemplos para minha vida.

A minha esposa Ana Cláudia, pelo amor, paciência e compreensão. Aos meus sogros Antonieta e Gilberto pelo apoio moral, financeiro e logístico. 


\section{AGRADECIMENTOS}

A Deus pela sabedoria e alento nos momentos difíceis.

Ao amigo e Prof ${ }^{\circ}$ Edmundo Escrivão Filho, pela sua humildade, pela seriedade e excelência na orientação da pesquisa e pela compreensão e dedicação demonstrada durante esses anos de convivência.

À Prof $f^{a}$ Terezinha das Graças Coletta pelas sugestões para definição do processo de gestão da informação.

Aos Professores Martinho e Cazarini pelas considerações que contribuíram para o resultado final deste trabalho.

Ao amigo e Prof ${ }^{o}$ Paulo Miranda pelo incentivo a minha carreira de pesquisador.

Ao Prof ${ }^{o}$ Aragão e ao Marco Leite pela receptividade em São Carlos e incentivo.

À FAPESP, pelo apoio financeiro e técnico para realização da pesquisa.

Aos meus amigos e companheiros de todos os momentos: Antônio, Kris, Rachel e José Henrique.

Aos amigos da república: Marco Antônio, Cloves, Guilherme e Marcelo, pelo incentivo e convivência.

Aos meus colegas de GEOPE: Carlos Alberto, Ana Cláudia Terence, Ana Cláudia Vicente, Giseli, Joseane, Rodrigo, Ana Laura, Marcos, Flávio, Sérgio, Alexandre Duarte e Mário, pela amizade e incentivo.

Ao Ricardo Kabbach, Evandro, Eloísa, Paulo, Karina, Sr. Fernando, Márcia e Mônica pela colaboração dispensada ao trabalho de campo.

Aos colegas de departamento, Silvana, Luiz Fernando, Ruth, Sueli e José Luiz pelo suporte para o desenvolvimento desse trabalho. 


\section{RESUMO}

ALBUQUERQUE, A. F. (2004). Gestão Estratégica das informações internas na pequena empresa: estudo comparativo de casos em empresas do setor de serviços (hoteleiro) da Região de Brotas - SP. 209f. Dissertação (Mestrado) - Escola de Engenharia de São Carlos, Universidade de São Paulo, São Carlos, 2004.

Este trabalho teve por objetivo apresentar propostas de melhoria no gerenciamento da informação interna visando à administração estratégica das pequenas empresas. Apresenta uma revisão bibliográfica sobre o processo de gestão da informação, as informações necessárias ao processo estratégico e as especificidades das pequenas empresas, o que permite definir as variáveis de pesquisa. No trabalho de campo foram estudadas quatro empresas hoteleiras de porte micro e pequeno, instaladas na cidade de Brotas/SP e uma média empresa sediada na cidade de Águas de São Pedro. A pesquisa de campo permitiu identificar as informações que são utilizadas para analisar os aspectos internos do hotel, como também a maneira que essas empresas coletam, processam e distribuem dados e informações aos tomadores de decisão. Verificou-se que os hotéis pesquisados apresentam mais facilidades do que dificuldades para o aprimoramento do processo de gestão estratégica da informação. Os dirigentes dos hotéis de pequeno porte não têm plena consciência dos benefícios que o gerenciamento da informação pode trazer. Alguns dados e informações relevantes para o hotel estão dispersos dentro da empresa e circulam de forma desestruturada, dificultando a recuperação pelos dirigentes na hora da tomada de decisão. Para melhoria do gerenciamento estratégico da informação foram apresentadas cinco propostas adequadas às especificidades da pequena empresa: conscientização dos dirigentes da relevância do processo de gerenciamento da informação; identificação das informações estratégicas a partir da compreensão do funcionamento do hotel; aperfeiçoamento dos instrumentos de coleta de dados; tratamento dos dados dispersos e ampliação da memória organizacional; exibição das informações em relatórios, formulários ou gráficos visualizados na tela do computador ou impressos em papel.

Palavras-chave: gestão da informação, informação estratégica, especificidades da pequena empresa, estratégia. 


\begin{abstract}
ALBUQUERQUE, A. F. (2004). Strategic management of inner information in small enterprises: comparative studies of cases in the hotel sector of Brotas-SP. Master dissertation - São Carlos Engineering School at São Paulo University, São Carlos, 2004.

This dissertation presents proposals for the management improvement of inner information aiming at the strategic management of small enterprises. It presents a bibliographical revision of the process of information management, the information necessary to the strategic process and the specific characteristics of small companies that permit defining the variable of the research. In the fieldwork four small hotel enterprises settled in Brotas city and a medium enterprise settled in Águas de São Pedro city were studied. Both cities are located in São Paulo region. This fieldwork allowed identifying the process of strategic decision-making, the information utilized in this activity as well as the way these companies collect, process and distribute the data and information to the people who make decisions. In a final evaluation it was possible to observe that the organizations analysed presented more facilities than difficulties to the improvement of the information management process. Managers of small hotel are not completely conscious of the benefits that information management can bring. Significant hotel data and information are scattered and flowing without control in the organizations, which hampers their recovery in the decision-making process. Aiming at the improvement of strategic information management five proposals were presented: making managers conscious of the importance of information management process; identification of strategic information by the comprehension of the hotel operation; improvement of data collecting tools; collection and analyses of scattered data and extension of organizational memory; exhibition of reports, graphs or formularies of information either printed or on computer screen.
\end{abstract}

Key words: information management, strategic information, characteristics of small companies, strategic. 


\section{LISTA DE FIGURAS}

Figura 01 - Informação e estratégia competitiva 18

Figura 02 - Escolas do pensamento estratégico 20

Figura 03 - Etapas da administração estratégica 22

Figura 04-Passos para análise dos aspectos internos 23

Figura 05 - Conceito de dados e informação 25

Figura 06 - Características da boa informação 26

\begin{tabular}{|lr}
\hline Figura 07 - Os componentes de um sistema de informação & 26 \\
\hline
\end{tabular}

Figura 08 - Relacionamento entre níveis hierárquicos, tipos de problemas, tipos de decisões e tipos de

sistemas de informações 28

Figura 09 - Etapas do processo de gerenciamento estratégico da informação 35

Figura 10 - Informações estratégicas disponíveis internamente na empresa 37

\begin{tabular}{|lc|}
\hline Figura 11 - Modelo de representação organizacional & 43 \\
\hline
\end{tabular}

Figura 12 - Especificidades ambientais da pequena empresa 44

Figura 13 - Especificidades estruturais da pequena empresa 46

Figura 14 - Especificidades comportamentais do dirigente da pequena empresa $\quad 50$

Figura 15 - Especificidades estratégicas da pequena empresa 53

Figura 16 - Especificidades tecnológicas da pequena empresa 55

Figura 17 - Quatro características que distinguem os serviços dos bens $\quad 61$

\begin{tabular}{|ll}
\hline Figura 18 - Tamanho do hotel & 63 \\
\hline
\end{tabular}

Figura 19-Classificação dos municípios pelo Ministério do Esporte e Turismo 65

Figura 20 - Esquema geral de orientação do trabalho de campo 73

\begin{tabular}{ll}
\hline Figura 21 - Detalhamento do esquema geral & 74 \\
\hline
\end{tabular}

Figura 22 - Etapas do processo de gerenciamento estratégico da informação

Figura 23 - Informações sobre os recursos e capacidades organizacionais $\quad 76$

\begin{tabular}{ll}
\hline Figura 24 - Informações de resultados & 77 \\
\hline
\end{tabular}

\begin{tabular}{|ll|}
\hline Figura 25 - Organograma do hotel A & 79 \\
\hline
\end{tabular}

Figura 26 - Organograma do hotel B. 81

Figura 27 - Organograma do hotel C 82

Figura 28 - Organograma do hotel D. $\quad 83$ 
Figura 29 - Organograma do hotel E

Figura 30 - Caracterização dos empreendimentos hoteleiros

Figura 31 - Dados coletados nas entrevistas 93

\begin{tabular}{|ll|}
\hline Figura 32 - Propostas de melhoria para o gerenciamento estratégico da informação & 104 \\
\hline
\end{tabular}

\begin{tabular}{|lc|}
\hline Figura 33 - Características dos indicadores de desempenho & 106 \\
\hline
\end{tabular}

Figura 34 - Dados coletados nas entrevistas (Hotel A) 148

Figura 35 - Dados coletados nas entrevistas (Hotel B) 153

Figura 36 - Dados coletados nas entrevistas (Hotel C) 158

\begin{tabular}{|lc|}
\hline Figura 37 - Dados coletados nas entrevistas (Hotel D) & 163 \\
\hline
\end{tabular}

\begin{tabular}{|lc|}
\hline Figura 38 - Dados coletados nas entrevistas (Hotel E) & 168 \\
\hline
\end{tabular} 


\section{LISTA DE TABELAS}

Tabela 1 - Importância sócio-econômica das MPEs 39

Tabela 2 - Representatividade das MPEs nos setores de atividades $\quad 40$

Tabela 3 - Formas de financiamento utilizados pelas MPEs $\quad 45$

Tabela 4 - Distribuição das empresas por cidade $\quad 66$ 


\section{LISTA DE ABREVIATURAS E SIGLAS}

CODETUR - Conselho de Desenvolvimento Turístico

COMTUR - Conselho Municipal de Turismo

FAPESP - Fundação de Amparo à Pesquisa do Estado de São Paulo

FCS - Fatores críticos de sucesso

FIPE - Fundação Instituto de Pesquisas Econômicas

GEOPE - Grupo de Estudos Organizacionais na Pequena Empresa

IBGE - Instituto Brasileiro de Geografia e Estatística

MPEs - Micro e pequenas empresas

MPMEs - Micro, pequenas e médias empresas

PMEs - Pequenas e médias empresas

SEBRAE - Serviço Brasileiro de Apoio às Micro e Pequenas Empresas

SEBRAE/SP - Serviço Brasileiro de Apoio às Micro e Pequenas Empresas do Estado de São Paulo

SEP-EESC-USP - Departamento de Engenharia de Produção da Escola de Engenharia de São Carlos da Universidade de São Paulo

SIE - Sistema de informações executivas

SIG - Sistema de informações gerenciais

SPT - Sistema de processamento de transações

TI - Tecnologia da informação 


\section{SUMÁRIO}

\section{RESUMO}

\section{ABSTRACT}

\section{LISTA DE FIGURAS}

\section{LISTA DE TABELAS}

\section{LISTA DE ABREVIATURAS E SIGLAS}

\begin{tabular}{|llr|}
\hline 1 & INTRODUÇÃO & 12 \\
\hline 1.1 & Caracterização do tema da pesquisa & 13 \\
\hline 1.2 & Formulação do problema da pesquisa & 14 \\
\hline 1.3 & Declaracão do objetivo da pesquisa & 15 \\
\hline 1.4 & Justificativa da pesquisa & 15 \\
\hline 1.5 & Motivação pela pesquisa & 16 \\
\hline 1.6 & Estrutura dos capítulos & 16 \\
\hline
\end{tabular}

\begin{tabular}{l}
\hline \begin{tabular}{llr}
\hline $\mathbf{2}$ & GESTÃO ESTRATÉGICA DA INFORMAÇÃO & $\mathbf{1 8}$ \\
\hline 2.1 & Caracterização do planejamento estratégico & $\mathbf{1 9}$ \\
\hline 2.1 .1 & Conceito de planejamento estratégico & 20 \\
\hline 2.1 .2 & Metodologias de planejamento estratégico & 21 \\
\hline 2.1 .3 & Análise interna & 22 \\
\hline 2.2 & Caracterização da informação & $\mathbf{2 4}$ \\
\hline $2.2 .1 \quad$ Conceito de informação & 25 \\
\hline 2.2 .2 & Sistema de informações & 26 \\
\hline 2.2 .3 & Gerenciamento estratégico da informação & 30 \\
\hline 2.2 .4 & Informação interna para decisão estratégica & 36 \\
\hline
\end{tabular}
\end{tabular}

\begin{tabular}{|l}
\hline \begin{tabular}{llr}
\hline $\mathbf{3}$ & GESTÃO DA PEQUENA EMPRESA & $\mathbf{3 9}$ \\
\hline $\mathbf{3 . 1}$ & Critérios para definicão das pequenas empresas & $\mathbf{4 0}$ \\
\hline $\mathbf{3 . 2}$ & Especificidades da pequena empresa & $\mathbf{4 2}$ \\
\hline 3.2 .1 & Dimensão ambiental & 43 \\
\hline 3.2 .2 & Dimensão organizacional: componente estrutura & 46 \\
\hline 3.2 .3 & Dimensão organizacional: componente comportamento & 48 \\
\hline 3.2 .4 & Dimensão organizacional: componente estratégia & 52 \\
\hline 3.2 .5 & Dimensão organizacional: componente tecnologia & 55 \\
\hline $\mathbf{3 . 3} \quad$ Gerenciamento estratégico da informação na pequena empresa & $\mathbf{5 7}$ \\
\hline 3.3 .1 & Proposta apresentada por MORAIS (1999) & 57 \\
\hline 3.3 .2 & Proposta apresentada por DALFOVO e RODRIGUES (1998) & 58 \\
\hline
\end{tabular}
\end{tabular}

\begin{tabular}{|lll|}
\hline 4 & TRABALHO DE CAMPO & $\mathbf{6 1}$ \\
\hline 4.1 & Caracterização do setor pesquisado & $\mathbf{6 1}$ \\
\hline 4.1 .1 & Operaçoses de serviços & 61 \\
\hline 4.1 .2 & Hotelaria & 62 \\
\hline
\end{tabular}




\begin{tabular}{|c|c|c|}
\hline 4.1 .3 & Setor turístico e hoteleiro da região de Brotas $-\mathrm{SP}$ & 64 \\
\hline 4.1 .4 & Caracterização das pequenas empresas hoteleiras da Região de Brotas & 67 \\
\hline 4.2 & Caracterização da metodologia da pesquisa & 69 \\
\hline 4.2 .1 & Tipo da pesquisa & 69 \\
\hline$\overline{4.2 .2}$ & Questões da pesquisa & 70 \\
\hline 4.2 .3 & Variáveis da pesquisa & 70 \\
\hline 4.2 .4 & Técnica de coleta e análise dos dados & 71 \\
\hline $\begin{array}{rr}4.3 & 1 \\
\end{array}$ & Fundamento conceitual & 72 \\
\hline 4.4 & Descrição das empresas estudadas & 78 \\
\hline 4.4 .1 & Hotel A & 78 \\
\hline 4.4 .2 & Hotel B & 80 \\
\hline 4.4 .3 & Hotel C & 81 \\
\hline 4.4 .4 & Hotel D & 82 \\
\hline 4.4 .5 & Hotel E & 83 \\
\hline
\end{tabular}

5 APRESENTAÇÃO E ANÁLISE DOS DADOS E PROPOSTAS DE MELHORIA

\begin{tabular}{llr}
\hline 5.1 & Apresentação dos dados & 86 \\
\hline
\end{tabular}

\begin{tabular}{llr}
\hline 5.2 & Análise comparativa dos dados & 95 \\
\hline
\end{tabular}

\begin{tabular}{llr}
5.3 & Propostas de melhoria no gerenciamento da informação interna & 104 \\
\hline
\end{tabular}

6 CONSIDERAÇÕES FINAIS 110

\begin{tabular}{|lr}
\hline REFERÉNCIA BIBLIOGRÁFICA & 120
\end{tabular}

\begin{tabular}{|lr|}
\hline APÊNDICES & 126 \\
\hline APÊNDICE A - Caracterização das empresas & 126 \\
\hline APÊNDICE B - Temas específicos de pesquisa & 130 \\
\hline APÊNDICE C - Roteiro de entrevista & 137 \\
\hline APÊNDICE D - Apresentação dos dados & 144 \\
\hline APÊNDICE E - Análise dos dados & 170 \\
\hline
\end{tabular}




\section{INTRODUÇÃO}

Desde a década de 70 a sociedade vem passando por transformações profundas. As mudanças de comportamento das variáveis sociais, econômicas e tecnológicas culminaram na decadência do modelo de produção em massa e ascensão do modelo japonês de produção enxuta. A partir desse período floresceu o movimento de reestruturação industrial, mudando a forma de produzir, distribuir e administrar das organizações, e alterou as relações entre os agentes econômicos.

Essa reformulação da estrutura produtiva, conduzida pelos grandes conglomerados, obrigou as empresas de grande porte a mudarem suas estratégias empresariais, o que veio possibilitar a abertura de novos espaços para inserção das pequenas empresas no mercado produtivo.

A partir dessa nova configuração da estrutura produtiva, Souza (1995) aponta quatro trajetórias de inserção para as pequenas e médias empresas (PMEs):

1) PMEs competindo em setores tradicionais da economia, com estratégia competitiva baseada em menores custos de mão-de-obra;

2) PMEs independentes em estruturas industriais dinâmicas, explorando nichos de mercado;

3) PMEs inseridas no mercado em forma de organizações coletivas e cooperativas, desenvolvendo ações conjuntas e coordenadas que permitam obter ganhos e vantagens decorrentes dessa estrutura organizativa;

4) PMEs vinculadas a grandes empresas, como fornecedoras ou distribuidoras, com maior ou menor grau de dependência e autonomia, como numa relação mais ou menos simbiótica.

Qualquer que seja a trajetória escolhida pela pequena empresa, ela não terá tarefa fácil para sobreviver. Precisará, pelo menos, de utilizar ferramentas gerenciais adequadas às suas características, que a ajudem a se preparar, hoje, para competir e ter sucesso no futuro. A administração estratégica do negócio apoiada por um sistema de 
informações executivas (SIE) é uma metodologia gerencial que pode contribuir para esse fim.

Através do SIE, que é desenvolvido para gerenciar estrategicamente a informação, a pequena empresa poderá: monitorar o comportamento das variáveis do ambiente, identificando possíveis oportunidades e ameaças; refletir sobre as suas capacidades organizacionais e recursos internos; analisar seu desempenho por meio do acompanhamento dos indicadores dos fatores críticos para o sucesso da organização e identificar suas forças e fraquezas, para que possa escolher o caminho que aproveite o que a empresa faz de melhor e atenda as demandas do ambiente.

\subsection{Caracterização do tema da pesquisa}

Gerenciar estrategicamente a informação interna significa utilizar as informações disponíveis dentro da empresa nas atividades de elaboração, execução e avaliação da estratégia, visando a obtenção de vantagem competitiva e o sucesso empresarial.

Através da informação a empresa poderá administrar estrategicamente seu negócio, ajudando os gerentes a decidir questões como: Onde investir? Que necessidade atender? De que forma? Qual a capacidade da empresa em atender melhor que o concorrente? Ou, no máximo, igualar-se a ele? Qual será a possível reação dos funcionários em relação ao novo caminho escolhido? A lucratividade continuará acima da média no novo negócio?

Para que essas informações sejam disponibilizadas à pessoa certa, no formato desejado e no momento oportuno, a empresa precisa desenvolver um sistema de informações executivas, que reúna, processe e distribua os dados e informações, necessários à administração estratégica.

Pozzebon e Freitas (1996, p. 20) definem sistema de informação executiva sob dois pontos de vista: o tecnológico e o filosófico.

Do ponto de vista filosófico, "trata-se do conceito de como administrar o negócio da empresa com base na administração das informações". As escolhas gerenciais serão apoiadas pelas informações provenientes do sistema de informações e não em pressentimentos ou intuição.

Do ponto de vista tecnológico, é considerado uma "ferramenta de pesquisa a bases de dados para a apresentação de informações de forma simples e amigável, atendendo às necessidades dos executivos". Fica claro que, para o SIE ser uma 
ferramenta útil aos tomadores de decisão, é preciso reconhecer que o gerenciamento da informação contribui para a boa administração da empresa e auxilia na descoberta e manutenção das vantagens competitivas.

Assim, esta filosofia precisa estar presente na vida das empresas e de seus dirigentes (inclusive as de pequeno porte) para que através do gerenciamento estratégico da informação interna, a empresa consiga minimizar as adversidades impostas pelo ambiente, tomando melhores decisões e aplicando os seus recursos escassos naquilo que traz resultados satisfatórios.

\subsection{Formulação do problema da pesquisa}

Basicamente, toda teoria administrativa - do movimento da administração científica ao movimento da contingência - foi desenvolvida através de estudos nas grandes corporações (impessoais, formais e profissionais predominantemente) para atender as suas demandas. "A aplicação desses modelos à gestão das micro, pequenas e médias empresas (MPMEs) é sempre inadequada", em função das especificidades dessas empresas (PINHEIRO, 1996, p.234).

Segundo Bortoli Neto (1980), a PME tem uma estrutura diferente e, dessa forma, a maneira de resolver seus problemas é específica. As PMEs não são "miniatura de uma grande empresa e que, portanto, uma uniformidade de tratamento para os problemas das PMEs e para as grandes seria inadequado" (COSTA GOMES ${ }^{\square}$ apud BORTOLI NETO, 1980, p.3).

Por isso, existe a resistência dos dirigentes dessas empresas em relação à aplicação das técnicas de gestão na condução do seu negócio.

Dessa forma, a essência da pesquisa está no seguinte questionamento:

Como a informação interna pode ser gerenciada pela pequena empresa, considerando suas especificidades de gestão, de modo que contribua à sua administração estratégica?

${ }^{1}$ COSTA GOMES, Oswaldo da. Manual de diagnóstico. - $3^{\mathrm{a}}$ ed. - São Paulo: desenvolvido para treinamento no CONPEC - Curso de Especialização em Consultoria a PMEs Comerciais, 1976. 


\subsection{Declaração do objetivo da pesquisa}

O objetivo geral desta pesquisa é apresentar propostas de melhoria no gerenciamento da informação interna visando à administração estratégica das pequenas empresas.

Como objetivos específicos:

1) Revisar a literatura sobre administração estratégica, gestão da informação e administração de pequenas empresas;

2) Identificar empiricamente as fontes internas e os tipos de informações estratégicas utilizadas pelas empresas de pequeno porte;

3) Identificar empiricamente os mecanismos de coleta, tratamento e distribuição das informações estratégicas utilizadas na pequena empresa;

4) Confrontar a teoria e a prática de gestão estratégica da informação.

\subsection{Justificativa da pesquisa}

A indústria de viagens e turismo tem sido considerada a maior do mundo e todos os estudos e projeções feitos para os próximos vinte anos apontam sua crescente consolidação (CARVALHO, 1998).

Dentro dessa indústria está a hotelaria, um setor baseado em capital intensivo e management (BENI, 1998), que tem por missão responder às carências de seus clientes com excelência, que julga os serviços prestados pelo detalhe (YÁZIGI, 2000). Entretanto, a falta de profissionalismo na gestão tem sido apontada como um dos problemas do turismo que precisam ser resolvidos no Brasil (BENI, 1998; YÁZIGI, 2000).

Nesse contexto do setor hoteleiro e com dificuldades em gerir, profissionalmente, o negócio, estão as pequenas empresas, reconhecidamente, grandes geradoras de riquezas e empregos para a sociedade, mas que apresentam um alto índice de mortalidade.

Dessa forma, para que a pequena empresa possa participar do crescimento dessa indústria, ela necessita se preparar para o futuro, num ambiente instável e com aumento crescente da concorrência. Ou seja, ela precisa criar as condições mínimas hoje, para competir e sobreviver no futuro. 
Para criar essas condições mínimas, é necessário administrar, estrategicamente, o negócio, apoiado no gerenciamento da informação. Mas, como foi mencionado, na formulação do problema da pesquisa, essas empresas não dispõem de ferramentas adequadas de gestão, conforme tem sido verificado pelos estudiosos da pequena empresa em várias partes do país.

Dessa forma, este trabalho visa contribuir com a diminuição do índice de mortalidade da pequena empresa, a partir do entendimento de suas especificidades, para que se possa propor melhorias no processo de gerenciamento estratégico das informações internas e este venha a apoiar as escolhas estratégicas dos dirigentes dessas empresas, colaborando para a consolidação desses empreendimentos na indústria promissora do turismo.

\subsection{Motivação pela pesquisa}

Desde a época de estudante em Administração, o pesquisador procura entender por que tantas empresas de pequeno porte abrem e fecham suas portas num período de tempo tão curto. Além dessa inquietação inicial, outros quatro motivos contribuíram para o estudo da pequena empresa: a oportunidade de realizar o mestrado e participar do grupo de estudos organizacionais na pequena empresa (GEOPE); o papel social e econômico que ela exerce para o desenvolvimento do Brasil; a opressão imposta pelo modelo econômico que beneficia as grandes empresas que concentram tecnologia e capital; a possibilidade de desenvolver ferramentas de gestão adequada a essa categoria de empresas, contribuindo para a sua sobrevivência e conseqüentemente, para uma sociedade mais justa e igualitária.

\subsection{Estrutura dos capítulos}

O texto está dividido em quatro capítulos. O capítulo 1 apresenta o propósito da pesquisa e sua relevância e as motivações do pesquisador para o desenvolvimento do tema de pesquisa.

O capítulo 2, gestão estratégica da informação demonstra as atividades da administração estratégica, reconhecendo as informações úteis ao processo de gestão, e 
as atividades do gerenciamento estratégico da informação proposta por cinco autores, identificando as etapas necessárias ao gerenciamento da informação.

O capítulo 3, gestão da pequena empresa, apresenta as especificidades de gestão da pequena empresa, identificando as limitações dessas empresas ao gerenciamento estratégico da informação.

No capítulo 4, é apresentada a caracterização do setor de pesquisa, abordando as características das operações em serviços, os processos organizacionais nos hotéis e o potencial turístico de algumas cidades da Região de Brotas. Descrevem-se também, as características da metodologia de pesquisa e apresenta-se a proposta teórica que será confrontada com a prática de gestão da informação dos hotéis de pequeno porte.

No capítulo 5 apresentam-se os dados coletados nas entrevistas com os dirigentes e durante a hospedagem do pesquisador nos hotéis, possibilitando a compreensão das especificidades da pequena empresa, do processo estratégico e do gerenciamento da informação. Apresenta-se, também, a análise dos dados e identificamse os aspectos semelhantes dos hotéis pesquisados, bem como, cinco propostas para melhoria do processo de gestão da informação estratégica baseada nesses aspectos.

No capítulo 6, são realizadas as considerações finais sobre o processo estratégico, as especificidades da pequena empresa e o aperfeiçoamento do processo de gerenciamento estratégico da informação interna. Descrevem-se, também, as limitações da pesquisa e as sugestões para realização de trabalhos futuros. 


\section{GESTÃO ESTRATÉGICA DA INFORMAÇÃO}

O gerenciamento estratégico da informação visa à obtenção de vantagem competitiva pela empresa através da utilização da informação com orientação estratégica (LESCA e ALMEIDA, 1994).

A orientação estratégica sugere três perspectivas relativas à utilização da informação (McGEE e PRUSAK, 1994) (figura 1):

- A informação utilizada para elaborar a estratégia;

- A informação necessária para implementar a estratégia;

- A informação usada para avaliar a estratégia.

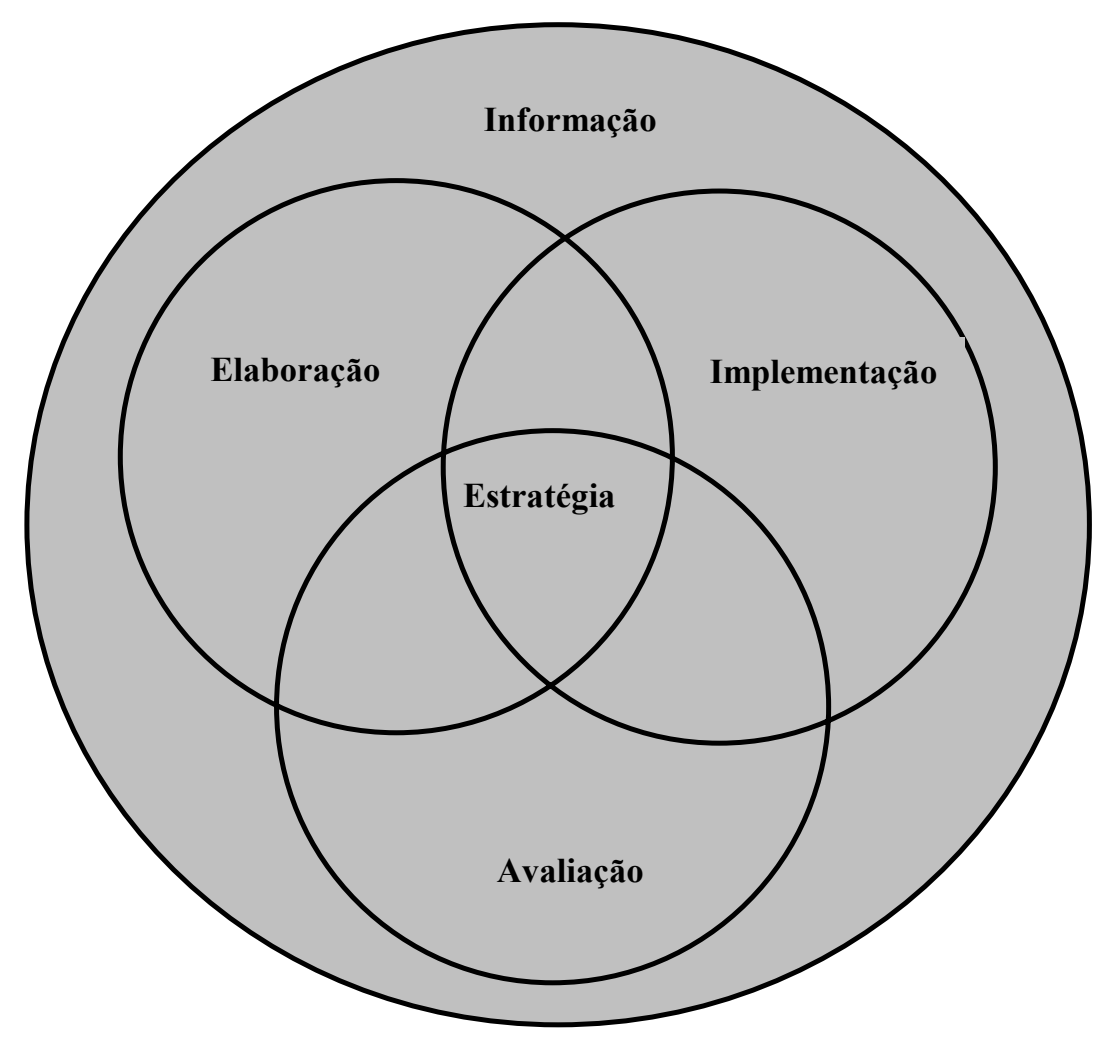

Figura 1 - Informação e Estratégia Competitiva

Fonte: Adaptado de McGEE e Prusak (1994, p.10) 
Dessa forma, a informação é imprescindível em todas as etapas do processo de gestão da estratégia empresarial.

\subsection{Caracterização do planejamento estratégico}

O conceito de estratégia teve origem no âmbito militar e significa a função do general de exército que se traduz em um plano com a finalidade de vencer as tropas inimigas (FREIRE, 1997). No meio empresarial o propósito da estratégia também é proporcionar a vitória, criando uma vantagem competitiva sustentável ${ }^{\text {Q }}$ que se traduza na preferência do consumidor pelos produtos da empresa.

O uso do conceito de estratégia em administração se deu a partir da década de 50 , em virtude das rápidas mudanças sociais, econômicas e políticas que moldavam o ambiente empresarial, exigindo das empresas uma adaptação a novos desafios (HAYASHI, NAKAMURA e ESCRIVÃO FILHO, 1995). Até esse período o ambiente industrial foi seqüencial, mas, entre 1950 e 1970, houve uma aceleração na turbulência ambiental, representando para a empresa a passagem de um mundo conhecido e de mudanças lentas para outro desconhecido e de mudanças repentinas (ANSOFF e McDONELL, 1993). O mapeamento desse ambiente desconhecido, encontrando o melhor caminho para a eficácia organizacional, é possível por meio do planejamento estratégico.

Em seus estudos, Mintzberg, Ahsltrand e Lampel (2000) apresentaram dez pontos de vista distintos sobre a formulação da estratégia, a maioria dos quais refletidos na prática gerencial e representados por dez escolas do pensamento estratégico (figura 2).

Para os autores da Escola do Planejamento como Ansoff e McDonell (1993), Almeida (2001), Betlhem (2002), Fischmann e Almeida (1991), Oliveira (2002a), Terence (2002), Thompson Jr e Strickland III (2000), a estratégia é um plano que mostrará o caminho que a organização deve seguir para sobreviver e ter sucesso no futuro. Representa a trajetória que indica como levar a empresa da situação atual para onde ela pretende chegar, escolhendo o que ser e fazer e o que não ser ou fazer, ou seja, concentrando-se só no que faz a diferença em determinado momento histórico.

\footnotetext{
${ }^{2}$ Sempre que a empresa tiver vantagem sobre as concorrentes para atrair os clientes e defender-se contra forças competitivas.
} 


\begin{tabular}{|l|l|}
\hline \multicolumn{1}{|c|}{ ESCOLA } & \multicolumn{1}{c|}{ FORMULAÇÃO DA ESTRATÉGIA } \\
\hline Design & Processo de Concepção \\
\hline Planejamento & Processo Formal \\
\hline Posicionamento & Processo Analítico \\
\hline Empreendedora & Processo Visionário \\
\hline Cognitiva & Processo Mental \\
\hline Aprendizado & Processo Emergente \\
\hline Poder & Processo de Negociação \\
\hline Cultural & Processo Coletivo \\
\hline Ambiental & Processo Reativo \\
\hline De configuração & Processo de Transformação \\
\hline
\end{tabular}

Figura 2 - Escolas do Pensamento Estratégico

Fonte: Mintzberg, Ahsltrand e Lampel (2000).

A escola do planejamento apóia-se em três premissas básicas (MINTZBERG, AHSLTRAND e LAMPEL, 2000, p.52):

- A estratégia é produto do planejamento formal, constituído por etapas distintas;

- Na teoria, a responsabilidade por todo o processo é do executivo principal; "na prática, a responsabilidade pela execução está com os planejadores";

- As estratégias devem ser explicitadas, para que possam ser implantadas.

Dessa forma, a estratégia será o resultado do processo de planejamento estratégico, que deverá ser fomentado e liderado pelo principal administrador, analisando e decidindo as principais ações que começarão a ser colocadas em prática hoje, para um desempenho eficaz da organização no futuro, perante seu ambiente ${ }^{\underline{B}}$.

\subsubsection{Conceito de planejamento estratégico}

O planejamento estratégico é uma técnica administrativa que procura ordenar as idéias das pessoas, mostrando o caminho que se deve seguir, como também as ações, para que, sem desperdício de recursos, se caminhe na direção almejada (ALMEIDA, 2001).

\footnotetext{
${ }^{3}$ Ambiente é tudo aquilo que tem influência no desempenho da organização e que ela nada ou muito pouco pode fazer (FISCHMANN e ALMEIDA, 1991).
} 
Kotler $^{1}$ (apud VASCONCELLOS FILHO, 1982, p.3) define o planejamento estratégico como sendo uma "metodologia gerencial que permite estabelecer a direção a ser seguida pela organização, visando maior grau de interação com o ambiente".

O planejamento estratégico é um exercício de reflexão sobre o que a empresa fez, está fazendo e pretende realizar, conhecendo suas potencialidades e dificuldades, bem como o comportamento das forças ambientais e sua influência positiva ou negativa no futuro da empresa. O produto desse pensamento sistematizado irá possibilitar que a alta administração decida o rumo que toda organização deverá seguir e comprometer-se com ele. Este rumo (estratégia) poderá ser: a penetração em novos mercados, a integração horizontal de produtos ou o caminho da inovação, entre outros.

Com o planejamento estratégico a empresa espera (OLIVEIRA, 2002a):

- Conhecer e melhor utilizar seus pontos fortes;

- Conhecer e eliminar ou adequar seus pontos fracos;

- Conhecer e usufruir as oportunidades externas;

- Conhecer e evitar as ameaças externas;

- Ter um efetivo plano de trabalho para a realização de todo processo.

\subsubsection{Metodologias de planejamento estratégico}

O número de metodologias disponíveis para a estruturação do planejamento estratégico é grande, mesmo assim, essas abordagens, normalmente, apresentam pontos semelhantes nas atividades que a empresa deve empreender para formular e implementar a estratégia (MINTZBERG, AHSLTRAND e LAMPEL, 2000).

Em sua dissertação de mestrado, Terence (2002) do GEOPE/EESC/USP estudou cinco metodologias: Fischmann ${ }^{5}$ (1987), Oliveira ${ }^{6}$ (1998), Certo e Peter (1993), Bethlem $^{\text {日 }}$ (1998), Thompson Jr. e Strickland III (2000), e sintetizou as principais etapas do processo estratégico. Sua proposta foi adaptada e descrita abaixo (figura 3):

- Análise externa e interna;

- Definição da missão e dos objetivos empresariais;

\footnotetext{
${ }^{4}$ KOTLER, P. (1975). Administração de marketing. São Paulo: Atlas.

${ }^{5}$ FISCHMANN, A. A. (1987). Implementação de estratégias: identificação e análise de problemas. Tese (Livre Docência). São Paulo, FEA-USP.

${ }^{6}$ OLIVEIRA, D. P. R. (1998). Planejamento estratégico: conceitos, metodologia e práticas. São Paulo: Atlas.

${ }^{7}$ BETHLEM, A. (1998). Estratégia empresarial: conceitos, processos e administração estratégica. São Paulo: Atlas.
} 
- Identificação da estratégia atual e estabelecimento da estratégia futura;

- Implementação da estratégia;

- Controle e avaliação da estratégia

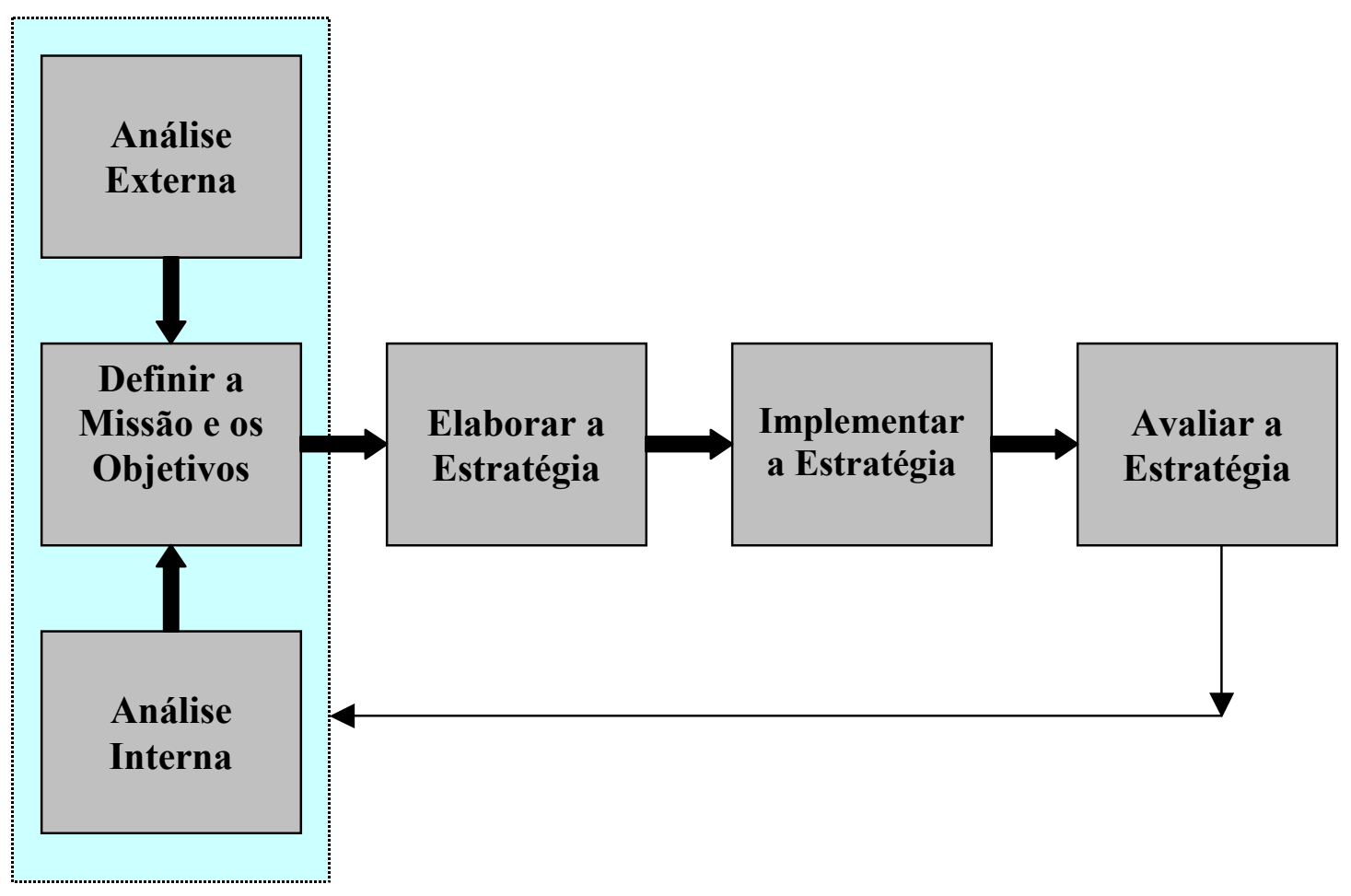

Figura 3 - Etapas da Administração estratégica

Fonte: Adaptado de Terence (2002)

\subsubsection{Análise interna}

O objetivo da presente pesquisa é a "Gestão Estratégica da Informação Interna", desta forma, esta seção destaca a etapa da "Análise Interna" da metodologia de planejamento estratégico em detrimento da análise das outras etapas.

A análise interna corresponde ao diagnóstico da situação atual da empresa, com o propósito de conhecer seus pontos fortes e fracos por meio da avaliação dos recursos e capacidades da empresa e dos resultados do seu desempenho atual.

$\mathrm{Na}$ análise dos aspectos internos (figura 4), Almeida propõe quatro passos. $\mathrm{O}$ primeiro passo é identificar os fatores que levam a empresa a cumprir sua missão ou vocação. Segundo Rockart (1979), esses fatores, considerados chave ou críticos para o sucesso da organização, representam um número limitado de áreas de atividades em que 
os resultados devem ser satisfatórios para que a organização seja competitiva, isto é, se destaque em relação aos seus concorrentes.

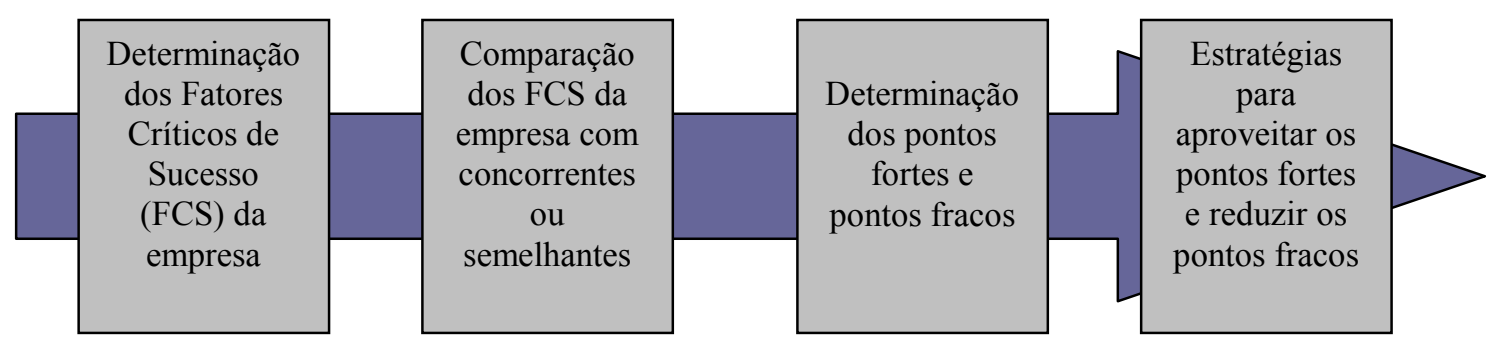

Figura 4 - Passos para análise dos aspectos internos

Fonte: Adaptado de Almeida (2001, p.18).

O segundo passo é comparar os FCS com os dos concorrentes e organizações afins, verificando aqueles que são superiores, inferiores ou semelhantes aos das empresas comparadas. Essa análise leva ao terceiro passo que é a identificação dos pontos fortes e fracos da organização. Em seguida, definem-se as estratégias, de forma a aproveitar os pontos fortes e minimizar os pontos fracos. Sendo este o último passo da análise dos fatores internos.

Bethlem (2002) propõe que sejam examinadas as principais áreas da empresa: recursos humanos, produção, finanças e marketing, para que sejam identificadas as vantagens competitivas da empresa que serão uma medida de sua capacidade competitiva expressa em termos de forças, ou as suas desvantagens expressa em termos de fraqueza.

$\mathrm{Na}$ análise dos recursos humanos, serão observados os conhecimentos sobre ambiente externo, recursos da empresa e de administração dos dirigentes de topo e se o clima da empresa e atitude do pessoal permitem a implementação de estratégias.

$\mathrm{Na}$ área de produção, a administração, ao formular uma estratégia, preocupa-se com a capacidade de a empresa produzir produtos na quantidade e qualidade desejadas e os custos necessários à implementação da estratégia formulada. Os dilemas mais comuns são: comprar ou fabricar? Equipamento especializado ou flexível? Estoques elevados ou menores? E muitos outros.

$\mathrm{Na}$ análise financeira, serão estabelecidos índices financeiros tirados dos balanços das empresas para comparação com os resultados da própria empresa e de outras empresas. Será necessário também analisar o próprio sistema de controle 
financeiro e contábil, sua organização e se os relatórios e demonstrativos estão aferindo o desempenho da empresa de forma a contribuir para a tomada de decisão.

A área de marketing requer dois tipos de análise: das estratégias de marketing (interação com o mercado) e do funcionamento da área. É preciso conhecer os recursos de marketing - a qualidade da gerência de marketing, sua capacidade de projetar um mix de marketing adequado e administrar a imagem da organização, bem como determinar a disponibilidade desses recursos no interior da empresa.

Pela explicação dos autores de como é realizada a análise interna, pode-se concluir que a identificação das forças (vantagens) e fraquezas (desvantagens) da empresa é produto das informações sobre os recursos e capacidades da empresa (que são críticos para o cumprimento da missão e objetivos empresariais), para desempenhar as atividades de marketing, de finanças, de produção e de recursos humanos, como também, do desempenho da estratégia atual, que serão comparados aos de outras empresas, concorrentes ou não.

As informações internas devem mostrar uma radiografia de suas capacidades e dos recursos disponíveis, expressando suas vantagens (melhor capacidade de fabricação, melhores campanhas de propaganda) ou desvantagens competitivas (falta de clareza na direção estratégica, instalações em mau estado, lucratividade abaixo da média, incapacidade de financiamento, habilidade deficiente da equipe de vendas).

\subsection{Caracterização da informação}

Desde a década de sessenta, com o impacto das transformações sociais, políticas, econômicas e tecnológicas nas organizações, mudando-se as formas de produzir, distribuir e administrar, a informação vem crescendo em importância e abrangência. Essas forças tornaram o ambiente mais instável, acirrando a concorrência e aumentando o grau de incerteza nas decisões. Esse cenário mais competitivo $\square_{\text {vem impondo às }}$ empresas novos desafios, exigindo o melhor conhecimento do comportamento das variáveis ambientais e da própria empresa. Tudo isso fez aumentar a demanda dos administradores por informações que ajudem as empresas a minimizar o risco e garantir a sobrevivência e o bom desempenho no futuro.

\footnotetext{
${ }^{8}$ Aumento acentuado da concorrência.
} 
$\mathrm{Na}$ empresa, o gerente poderá se deparar com algumas dessas questões: Onde investir? A oportunidade é atrativa? Que necessidade atender? De que forma? Quem será o beneficiário? A empresa terá capacidade de atender melhor que a concorrente? Ou no máximo iguala-se a ela? Como os funcionários estão reagindo em relação ao novo caminho escolhido? E a lucratividade, ficou acima da média? É viável permanecermos nesse rumo? É difícil responder a essas perguntas sem as informações adequadas, no momento da tomada de decisão.

\subsubsection{Conceito de informação}

A explicação dos conceitos de dado e de informação é essencial à compreensão do gerenciamento estruturado da informação, o ponto central deste trabalho. Segundo Oliveira (2002b, p.36), dado "é qualquer elemento identificado em sua forma bruta que, por si só, não conduz a uma compreensão de determinado fato ou situação". Os dados precisam ser processados (interpretados) para se transformarem em informação (figura $5)$.

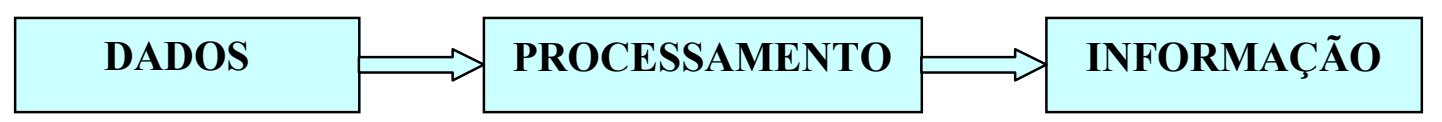

Figura 5 - Conceito de dados e informação

Fonte: elaboração própria

Os dados "são os itens básicos de informação" antes de serem interpretados em um sistema, "enquanto informações são os relatórios, os resultados do processamento de dados" (CASSARO, 2001). O nome do funcionário e o número de peças produzidas em uma semana são dados. O resultado da análise desses dados é a informação. O que vai permitir ao gerente conhecer o desempenho desse funcionário e tomar uma decisão em relação a este resultado.

Desse modo, a informação "é o dado trabalhado que permite ao executivo tomar decisões" (OLIVEIRA, 2002b, p.36), habilitando-o a utilizar os recursos com eficiência para o alcance dos objetivos organizacionais.

Assim, para que a informação habilite os gerentes a tomarem as melhores decisões, a empresa precisa ter capacidade para reunir e processar dados em determinado contexto. É necessário, também, que a informação a ser coletada e registrada possua as seguintes características (figura 6): 


\begin{tabular}{|l|l|}
\hline CARACTERÍSTICAS & DEFINICÕES \\
\hline PRECISA & Sem erros \\
\hline COMPLETA & Contém todos os fatos importantes \\
\hline ECONÔMICA & De produção relativamente econômica \\
\hline FLEXÍVEL & Pode ser usada para diversas finalidades \\
\hline CONFIÁVEL & Depende da fonte de informação \\
\hline RELEVANTE & Importante para o tomador de decisões \\
\hline SIMPLES & Não deve ser exageradamente complexa \\
\hline EM TEMPO & Enviada quando necessário \\
\hline VERIFICÁVEL & Pode-se checá-la para saber se está correta \\
\hline
\end{tabular}

Figura 6 - Características da boa informação

Fonte: Stair (1998, p.6)

\subsubsection{Sistema de informações}

Um sistema de informação (figura 7) "é uma série de elementos interrelacionados que coletam (entrada), manipulam e armazenam (processo), disseminam (saída) os dados e informações e fornecem um mecanismo de feedback" (STAIR, 1998, p.11). A entrada é a atividade de captar e reunir dados. O processamento envolve a transformação dos dados em saídas úteis. A saída representa as informações úteis, normalmente na forma de documentos, relatórios etc. Feedback é a saída usada para fazer correções nas atividades de processamento ou entrada.

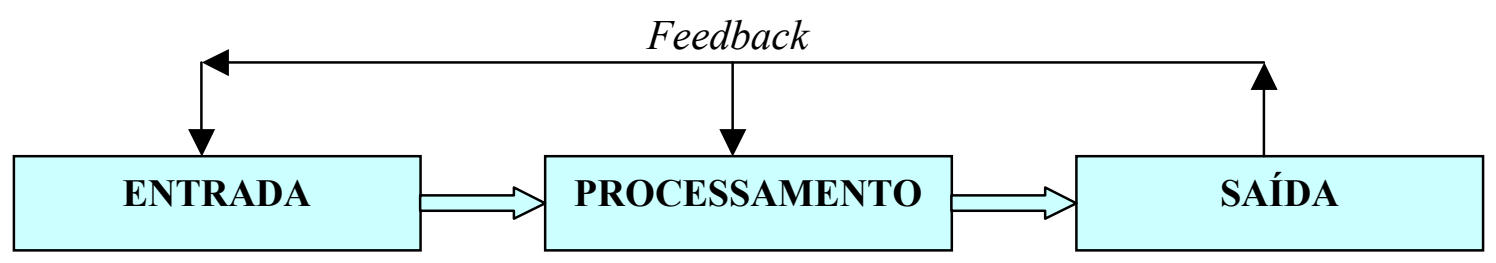

Figura 7 - Os componentes de um sistema de informação

Fonte: Stair (1998, p.11)

Segundo BEUREN e MARTINS (2001, p.8) "um sistema de informação consiste em uma soma estruturada de elementos". São baseados em "quatro componentes correlacionados de modo a permitir o melhor atendimento dos objetivos da organização" (CAMPOS FILHO, 1994): 
- A informação - dados formatados, imagens, sons e textos livres;

- Os recursos humanos - coletam, processam, recuperam e utilizam dados;

- As tecnologias de informação - o hardware e o software usados no processamento dos dados;

- As práticas de trabalho - representam os métodos utilizados pelos recursos humanos para desempenhar as atividades do sistema de informação.

Para Chichinelli e Cazarini (2002, p.2), ao desenvolver sistemas de informação é imprescindível considerar as limitações do produto (desempenho, confiabilidade e segurança) e do desenvolvimento do processo (custos, métodos adotados e componentes do sistema), "visto que, a não consideração dos mesmos, leva a um alto custo de manutenção e conseqüente desenvolvimento de sistemas de baixa qualidade".

Os sistemas de informações são desenvolvidos para dar suporte ao processo decisório nos níveis estratégico, tático e operacional da organização. São estruturados para:

- Suportar as atividades não gerenciais e operacionais - sistema de processamento de transações (SPT);

- Ajudar os administradores a tomarem decisões nas áreas de negócio (marketing, finanças etc) através da análise dos relatórios gerenciais - sistema de informações gerenciais (SIG);

- Produzir informações sobre a empresa e seu ambiente, como também, para acompanhar seu desempenho global - sistema de informações executivas (SIE).

Os sistemas de processamento de transações "representam a aplicação dos conceitos e tecnologia de informação em transações rotineiras, repetitivas e geralmente comuns de negócios" (STAIR, 1998, p.15). Uma transação significa qualquer troca de valor ou movimento de mercadorias que afete o desempenho organizacional. São objetivos do SPT: processar dados gerados por e sobre transações; manter um alto grau de precisão; assegurar a integridade dos dados e da informação e produzir documentos e relatórios em tempo. O SPT também é usado para obter vantagem competitiva, como: serviços superiores aos clientes; melhor agrupamento de informações e aperfeiçoamento de previsões e planejamento (STAIR, 1998).

O sistema de informações gerenciais (SIG) "é um conjunto organizado de pessoas, procedimentos, bancos de dados e dispositivos que fornece aos administradores e tomadores de decisões as informações para ajudá-los a atingir as metas da empresa" (STAIR, 1998, p. 226). 
Furlan, Ivo e Amaral (1994, p.28-29) identificam como características do SIG: "foco na informação direcionada a gerentes de nível médio; fluxo de informações estruturado; integração dos sistemas por área funcional; e geração de relatórios e consultas, normalmente com uso de um banco de dados". Segundo os autores, o SIG produz informações sumarizadas sobre o comportamento passado dos negócios através de totalizações. Consolida as operações (transações) realizadas.

Stair (1998) ressalta ainda que o SIG e o SPT colaboram para a solução de problemas semi-estruturados e estruturados (figura 8) respectivamente. Já, o sistema de informações executivas (SIE) auxilia os gerentes a tomarem decisões, considerando problemas semi-estruturados e não-estruturados. Os problemas estruturados - simples e com fatos e relacionamentos conhecidos - estão relacionados às decisões programadas, tomadas mediante regras ou método quantitativo. Enquanto os problemas semiestruturados ou não- estruturados - mais complexos, sem clareza dos dados e definição dos seus relacionamentos - estão associados a decisões não-programadas, tomadas em situações incomuns ou excepcionais.

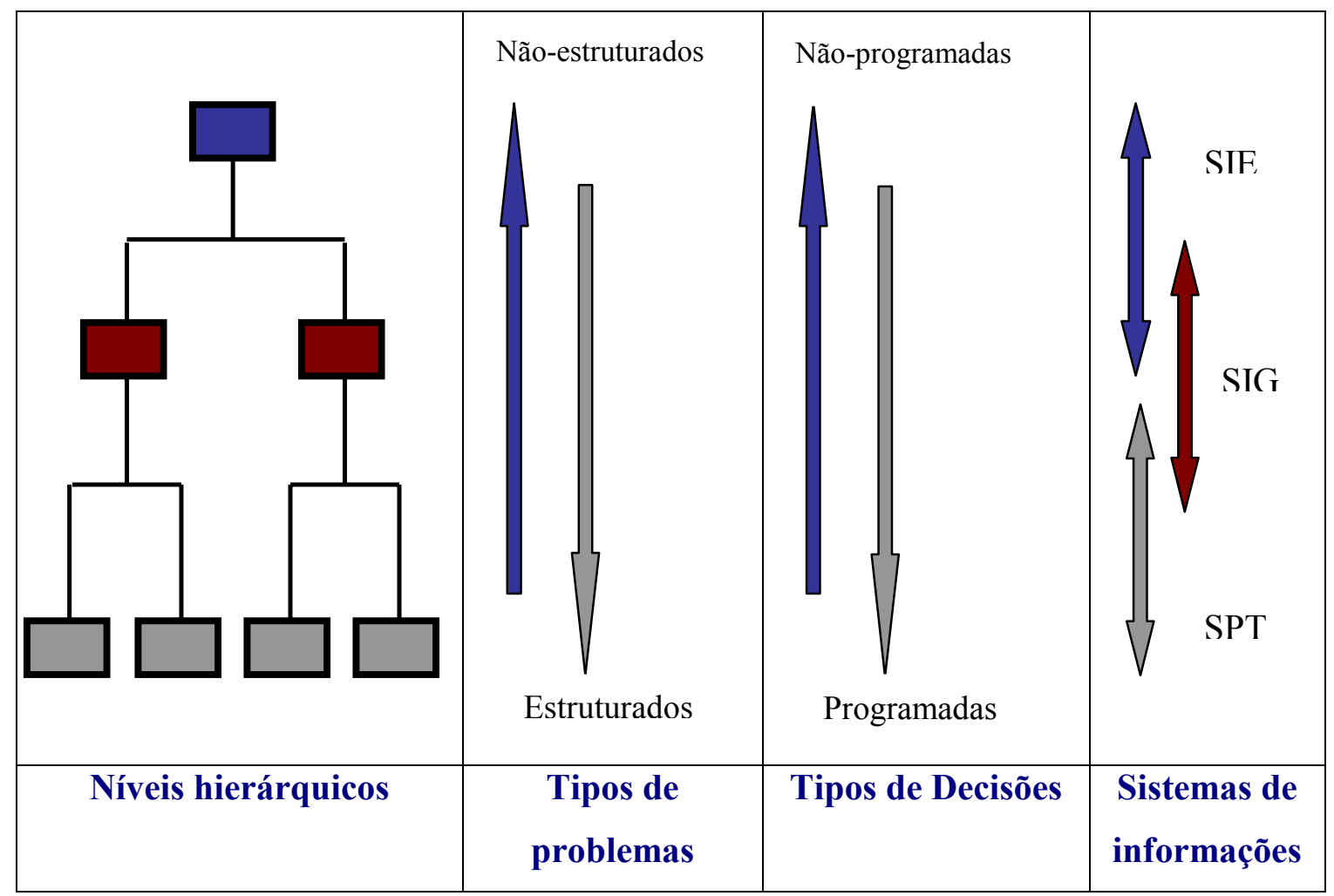

Figura 8 - Relacionamento entre níveis hierárquicos, tipos de problemas, tipos de decisões e tipos de sistemas de informações.

Fonte: elaboração própria 
Para Stair (1998, p.245) o SIE “é um sistema de suporte à decisão especializado que inclui todo o hardware, software, dados, procedimentos e pessoas utilizadas para auxiliar os executivos de nível sênior da organização". Como Pozzebon e Freitas (1996), Stair (1998) afirma que o "SIE é uma ferramenta útil e interativa", que possibilita ao executivo focalizar, filtrar e armazenar dados e informações úteis à tomada de decisão.

O SIE tem como principal finalidade otimizar o desempenho da empresa, mostrando as várias alternativas para resolver os problemas organizacionais, indicando novas direções que a empresa pode seguir e monitorando o seu desempenho, através do acompanhamento dos indicadores relacionados aos fatores críticos de sucesso (POZZEBON e FREITAS, 1996; STAIR, 1998; BEUREN e MARTINS, 2001).

Segundo BEUREN e MARTINS (2001, p.13) "O objetivo de um sistema de informação executiva é ajudar o decisor na assimilação rápida de informações e na identificação de problemas e oportunidades, não é uma ajuda na análise de problemas ou na sua resolução".

Para que o SIE cumpra sua missão, fornecendo as informações corretas, no formato desejado, a pessoa certa e no momento oportuno, são características desejáveis (POZZEBON e FREITAS, 1996; STAIR, 1998; BEUREN e MARTINS, 2001):

- Facilidade de uso - pouco treinamento e aprendizado fácil;

- Variedade de recursos gráficos - explorar ícones, gráficos, cores, símbolos e imagens, um gráfico muitas vezes transmite mais informações que mil palavras ou números;

- Disponibilidade e variedade de informações internas e externas - fornecer dados e informações: de resultados, do ambiente da empresa e das forças e fraquezas organizacionais;

- Flexibilidade - adaptável às mudanças ambientais e necessidades do executivo;

- Filtragem e resumo - geração de informações nos formatos de interesse do executivo;

- Possibilidade de drill down - aprofundamento no nível de detalhe das informações;

- Variedade de recursos computacionais - permitir a rápida recuperação de informações.

Enfim, um sistema de informações executivas deve ser capaz de dar suporte à definição de uma visão geral da organização, ao planejamento estratégico, à 
organização estratégica e de pessoal; ao controle estratégico e ao gerenciamento de crises (STAIR, 1998), de forma rápida e simplificada.

\subsubsection{Gerenciamento estratégico da informação}

Para que seja assegurado o valor estratégico da informação, é necessário um conjunto de tarefas (modelo de gerenciamento) conectadas logicamente sob a responsabilidade de um gestor (BEUREN, 2000).

O modelo concebido para o gerenciamento da informação precisa levar em conta que a natureza do processo decisório é não-estruturada e não-repetitiva e que os cenários que cercam a tomada de decisões estão em constante mudança (POZZEBON e FREITAS, 1996).

Para McGee e Prusak (1994, p.107), esse modelo de descrição do gerenciamento da informação deve ser genérico por duas razões (McGEE e PRUSAK, 1994, p.107):

- “A informação recebe ênfase diferente em cada segmento econômico e em cada organização;

- As diferentes tarefas dentro do modelo assumem diferentes níveis de importância e valor entre as organizações".

A literatura sobre o processo de gerenciamento estratégico da informação apresenta diferentes terminologias, sendo, a mais comum, a terminologia de sistema de informações executivas. Apesar dessa variedade, algumas etapas são comuns nesse processo (McGEE e PRUSAK, 1994; POZZEBON e FREITAS, 1996; MORAIS, 1999; BEUREN, 2000; OLIVEIRA, 2001):

\section{a) $1^{\text {a }}$ etapa - Compreensão do papel do SIE}

A primeira etapa é compreender o papel do SIE na gestão do negócio. Inicialmente, deve-se identificar a razão da estruturação do SIE, isto é, compreender o que o sistema pode ou não fazer pela administração do negócio (POZZEBON e FREITAS, 1996; OLIVEIRA, 2001), para evitar o delineamento de um sistema que colete dados e informações irrelevantes ao processo estratégico.

Nesta etapa, define-se a equipe de trabalho do projeto, treina-se a equipe, ministram-se cursos sobre o SIE, realizam-se estudos sobre a realidade da empresa, fazse o levantamento das informações já recebidas pelo executivo e define-se o software a ser utilizado no desenvolvimento do SIE (POZZEBON e FREITAS, 1996). É uma etapa de conhecimento das possibilidades do SIE e do negócio que o sistema irá apoiar. 


\section{b) $2^{a}$ etapa - Identificação da necessidade de informação}

A segunda etapa consiste na identificação da necessidade de informação dos usuários e análise de onde (fontes) e como buscar (coletar) estas informações. b1) $1^{\circ}$ passo - Identificar fontes de informações

O primeiro passo diz respeito ao número de fontes de informações que irão alimentar o sistema de informações. Será tão variado quanto o ambiente que a empresa procura interpretar (McGEE e PRUSAK, 1994). Nesse sentido, a necessidade de informação terá uma relação direta com a complexidade e rapidez das mudanças de comportamento dos fatores que influenciam a gestão da organização.

Oliveira (2001) ressalta também que existe uma oferta abundante de fontes de dados para a empresa, sendo necessário analisar a relação custo versus benefício para seleção dessas fontes.

b2) $2^{\circ}$ passo - Identificar os tipos de informações

O segundo passo está relacionado à identificação da necessidade de informação dos executivos. Segundo McGee e Prusak, (1994), os executivos normalmente, quando são entrevistados pelo profissional da informação, ficam apáticos para responder-lhes as perguntas. Eles têm dificuldade em saber se as informações existem e estão disponíveis dentro ou fora da empresa, e como fazer para obtê-las em tempo hábil. Sugerem que o profissional de informação precisa conhecer as fontes de informações disponíveis, que poderão ter utilidade aos executivos e sua organização.

As informações necessárias ao usuário devem permitir uma visualização clara do desempenho da empresa em suas diferentes áreas; destaque e projeção de tendências e alerta para o gerenciamento e a análise de problemas reais ou potenciais e oportunidades (POZZEBON e FREITAS, 1996).

Rockart (1979) propõe que o executivo considere as informações relacionadas aos FCS que sustentam os objetivos da empresa, pois a identificação dos fatores críticos permite uma clara definição da quantidade de informações que devem ser analisadas pela organização, livrando-a da armadilha de elaborar relatórios ou construir um sistema de informação cercado de dados que são fáceis de coletar, mas insignificantes para o monitoramento do andamento do negócio. Além disso, o diagnóstico dos FCS força o gerente a desenvolver medidas de desempenho para cada fator identificado.

b3) $3^{\circ}$ passo - Coleta de dados

O último passo desta etapa refere-se à coleta dos dados. Após a definição consensual das informações necessárias aos usuários, deve ser concebido um plano para 
aquisição da informação de sua fonte de origem ou para coletá-la (eletrônica ou manualmente) internamente (McGEE e PRUSAK, 1994).

Segundo Oliveira (2001), para coletar as informações existe a necessidade mínima da empresa possuir um sistema de pesquisa de mercado e um sistema de indicadores de fatores ambientais para alimentar o SIE.

No mesmo sentido, Pozzebon e Freitas (1996) sugerem que seja projetado um sistema com quatro blocos: 1) Informações da empresa; 2) Inteligência - informações externas; 3) Percepções dos clientes - pesquisas de opiniões e 4) Decisão, com ferramentas de simulação e análise de dados.

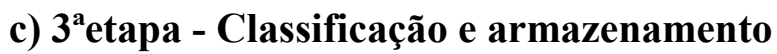

A terceira etapa consiste na classificação e armazenamento da informação. A classificação consiste na definição da maneira como os usuários poderão ter acesso às informações necessárias e o armazenamento na seleção do melhor lugar para arquivá-las (fita cassete, transcrições em papel, gravações em vídeo ou cd-roms) (McGEE e PRUSAK, 1994).

Os autores recomendam observar três pontos:

1) Certificar-se que o sistema está adaptado ao modo como os usuários utilizam a informação - interface sistema-usuário;

2) Encarar a classificação das informações por várias óticas - ordenar de acordo com a natureza do material representado, com "índices on-line ou impressos, permitindo a escolha do material a partir do estilo de apresentação, metodologia, cliente atual ou em potencial, público receptivo, hostil ou indiferente" (McGEE e PRUSAK, 1994, p.118);

3) Não ignorar a dimensão do projeto - oferecer aos usuários apenas as informações estritamente relevantes, para que eles possam obter uma resposta rápida às suas necessidades de decisão.

Pozzebon e Freitas (1996) propõem a criação de um ranking de classificação das informações básicas ${ }^{\frac{1}{2}}$ dos indicadores ${ }^{10}$, atribuindo-se um peso a cada indicador de acordo com a importância e a disponibilidade das informações básicas. Para que isso seja possível, analisa-se a unidade, o nível de apuração, a periodicidade e a localização das informações básicas. Em seguida, analisa-se a unidade, a fórmula de cálculo, as informações envolvidas, a finalidade, o nível de apuração, a periodicidade e o conceito

\footnotetext{
${ }^{9}$ Informações elementares das áreas financeira, de produção, de marketing etc.

${ }^{10}$ Manipulação e combinação das informações básicas ou elementares.
} 
dos indicadores de desempenho. O ranking representa a organização das informações pelo seu grau de importância e facilidade de obtenção.

Mattar (1996) sugere ainda, que é necessário definir, para cada tipo de informação a maneira como ela será arquivada; o nível de agregação das informações; e o tempo de permanência em estoque.

Outra questão importante é a influência que a classificação e o armazenamento terão no tempo de realização das atividades de consulta e recuperação de dados e informações pelos usuários do sistema de informações executivas.

d) $4^{\text {a }}$ etapa - Tratamento e apresentação da informação

A quarta etapa do processo de gerenciamento estratégico da informação é o tratamento e apresentação da informação.

A tarefa de tratamento e apresentação da informação, "normalmente ocorre juntamente com a tarefa de classificação e armazenamento de dados e informações" (McGEE e PRUSAK, 1994; BEUREN, 2000). Após o arquivamento de dados e informações o profissional da informação pode escolher diferentes metodologias e representações para colocar à disposição dos usuários uma variedade de fontes e estilos de informações.

O tratamento dos dados envolve: registro, apreciação do conteúdo, elaboração de sínteses, condensação das informações relevantes e indexação (MORAIS, 1999).

Para Pozzebon e Freitas (1996, p.25), as etapas anteriores definiram o que o sistema deverá exibir. Esta etapa consiste na descrição das características gráficas do sistema, como exibir as informações, ou seja, "define como o sistema implementará graficamente os requisitos gerais e específicos já determinados”. Deve projetar-se uma tecnologia que permita ao usuário analisar automaticamente os indicadores de desempenho e as informações nos níveis de detalhamento desejado. Os autores também ressaltam que outra característica importante no SIE é oferecer ao usuário a opção de visualização gráfica ou numérica de dados. Por exemplo, gráfico de pizza para informações sobre a composição do faturamento; gráfico de barras para evolução do crescimento da receita etc.

\section{e) $5^{\text {a }}$ etapa - Desenvolvimento de produtos de informação}

A quinta etapa consiste no desenvolvimento de produtos e serviços de informação (McGEE e PRUSAK, 1994; MORAIS, 1999; BEUREN, 2000). Nesta etapa a experiência e o conhecimento dos usuários podem trazer boas perspectivas ao processo (McGEE e PRUSAK, 1994; BEUREN, 2000). Os autores ressaltam a 
importância do elemento humano. Para McGee e Prusak (1994), quanto mais estratégico é um sistema de informações, mais esforços humanos são necessários para mantê-lo.

\section{f) $6^{a}$ etapa - Disseminação da informação}

A sexta etapa consiste na disseminação da informação (McGEE e PRUSAK, 1994; MORAIS, 1999; BEUREN, 2000; OLIVEIRA, 2001). A disseminação consiste na distribuição sistemática e estruturada, aos tomadores de decisão, das informações estratégicas provenientes da interpretação dos dados coletados. Lembrando a importância de eliminar tudo o que não é essencial à gestão empresarial (OLIVEIRA, 2001).

Morais (1999, p.25) afirma que é fundamental utilizar técnicas e produtos de comunicação adequados a cada tipo de usuário das informações, "considerando, além dos aspectos de formato e linguagem, o componente tempo, isto é, a periodicidade de elaboração e disseminação da informação". Para a autora os principais tipos de relatórios utilizados para distribuir a informação são: boletins, perfis (informações gerais), planilhas, resumos e análises de situação.

Além de utilizar sua rede normal de comunicação, a empresa pode criar unidades de informação que se encarreguem da identificação e do atendimento das demandas informativas dos tomadores de decisão (McGEE e PRUSAK, 1994; BEUREN, 2000).

\section{g) $7^{\text {a }}$ etapa - Utilização da informação}

Após a disseminação, vem a utilização dos dados e informações na empresa, a sétima etapa do processo de gerenciamento estratégico. Significa a incorporação dos dados e informações no processo decisório da empresa (OLIVEIRA, 2001). Os executivos irão realizar suas análises e utilizar estas informações nas etapas do processo de gestão estratégica: elaboração, execução e avaliação da estratégia empresarial.

\section{h) $8^{\text {a }}$ etapa - Avaliação das informações}

E por fim, a realimentação ou feedback dos dados e informações (MORAIS, 1999; OLIVEIRA, 2001). “Consiste na constante, sistemática e estruturada adaptação do processo decisório estratégico, de acordo com os resultados obtidos pela empresa, para atender cada vez melhor às necessidades de informações dos executivos" (OLIVEIRA, 2001, p.163).

Após a descrição das etapas acima, observa-se a grande semelhança quanto às atividades necessárias ao desenvolvimento do processo de gestão estratégica da informação. A figura 9 mostra as principais etapas citadas pelos autores, algumas vezes com denominação diferente, mas conceito semelhante. 


\begin{tabular}{|c|c|c|c|c|c|}
\hline Etapas & $\begin{array}{c}\text { McGEE e } \\
\text { PRUSAK (1994) }\end{array}$ & $\begin{array}{l}\text { POZZEBON e } \\
\text { FREITAS (1994) }\end{array}$ & $\begin{array}{l}\text { MORAIS } \\
\text { (1999) }\end{array}$ & BEUREN (2000) & $\begin{array}{l}\text { OLIVEIRA } \\
(2001)\end{array}$ \\
\hline $1^{\mathrm{a}}$ & & $\begin{array}{l}\text { Compreensão do } \\
\text { papel do SIE }\end{array}$ & & & $\begin{array}{l}\text { Identificação } \\
\text { da razão da } \\
\text { estruturação } \\
\text { dos SIE }\end{array}$ \\
\hline \multirow[t]{2}{*}{$2^{\mathrm{a}}$} & $\begin{array}{lr}\text { Identificação } & \text { das } \\
\text { necessidades } & \mathrm{e} \\
\text { requisitos } & \text { de } \\
\text { informação } & \end{array}$ & $\begin{array}{ll}\text { Definição } & \text { de } \\
\text { informações } & \\
\text { básicas } & \text { e } \\
\text { indicadores } & \\
\end{array}$ & $\begin{array}{l}\text { Planejamento } \\
\text { necessidade de } \\
\text { informação } \mathrm{e} \\
\text { atores } \\
\text { envolvidos }\end{array}$ & $\begin{array}{lr}\text { Identificação } & \text { das } \\
\text { necessidades } & \mathrm{e} \\
\text { requisitos } & \text { de } \\
\text { informação } & \\
\end{array}$ & $\begin{array}{l}\text { Administração } \\
\text { da informação }\end{array}$ \\
\hline & $\begin{array}{l}\text { Coleta/entrada de } \\
\text { informação }\end{array}$ & 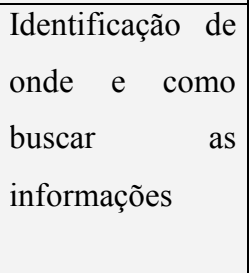 & $\begin{array}{ll}\text { Coleta } & - \\
\text { identificação } & \text { e } \\
\text { seleção de } & \text { fontes, coleta de } \\
\text { dados e triagem }\end{array}$ & $\begin{array}{l}\text { Coleta/entrada de } \\
\text { informação }\end{array}$ & \multirow{3}{*}{$\begin{array}{l}\text { Geração e } \\
\text { arquivamento } \\
\text { da informação } \\
\text { e } \\
\text { Controle e } \\
\text { avaliação }\end{array}$} \\
\hline $3^{a}$ & $\begin{array}{l}\text { Classificação e } \\
\text { armazenamento da } \\
\text { informação }\end{array}$ & $\begin{array}{l}\text { Criação de } \\
\text { ranking } \\
\text { classificação das } \\
\text { informações } \\
\text { básicas e dos } \\
\text { indicadores }\end{array}$ & $\begin{array}{l}\text { Tratamento da } \\
\text { informação - } \\
\text { processamento } \\
\text { de dados e } \\
\text { armazenamento }\end{array}$ & $\begin{array}{l}\text { Classificação } \mathrm{e} \\
\text { armazenamento da } \\
\text { informação }\end{array}$ & \\
\hline $4^{a}$ & $\begin{array}{lr}\text { Tratamento } & \mathrm{e} \\
\text { apresentação } & \mathrm{da} \\
\text { informação } & \end{array}$ & $\begin{array}{ll}\text { Protótipo } & - \\
\text { como exibir as } & \\
\text { informações } & \end{array}$ & \multirow[t]{2}{*}{\begin{tabular}{|lr} 
Análise & $\mathrm{e}$ \\
validação & $\mathrm{da}$ \\
informação & \\
\end{tabular}} & $\begin{array}{lr}\text { Tratamento } & \mathrm{e} \\
\text { apresentação } & \mathrm{da} \\
\text { informação } & \end{array}$ & \\
\hline $5^{\mathrm{a}}$ & $\begin{array}{l}\text { Desenvolvimento } \\
\text { de produtos e } \\
\text { serviços de } \\
\text { informação }\end{array}$ & & & \begin{tabular}{ll}
\multicolumn{3}{|l|}{ Desenvolvimento } \\
de produtos & e \\
serviços & de \\
informação
\end{tabular} & \\
\hline $6^{\mathrm{a}}$ & $\begin{array}{lr}\text { Distribuição } & \mathrm{e} \\
\text { disseminação } & \mathrm{da} \\
\text { informação } & \end{array}$ & & \multirow[t]{3}{*}{$\begin{array}{l}\text { Utilização, } \\
\text { disseminação e } \\
\text { avaliação }\end{array}$} & $\begin{array}{lr}\text { Distribuição } & \text { e } \\
\text { disseminação } & \text { de } \\
\text { informação } & \end{array}$ & $\begin{array}{l}\text { Disseminação } \\
\text { dos dados e } \\
\text { informações }\end{array}$ \\
\hline $7^{\mathrm{a}}$ & $\begin{array}{l}\text { Análise e uso da } \\
\text { informação }\end{array}$ & & & $\begin{array}{l}\text { Análise e uso da } \\
\text { informação }\end{array}$ & $\begin{array}{lr}\text { Utilização } & \text { dos } \\
\text { dados } & \mathrm{e} \\
\text { informação } & \end{array}$ \\
\hline $8^{\mathrm{a}}$ & & & & & Realimentação \\
\hline
\end{tabular}

Figura 9 - Etapas do processo de gerenciamento estratégico da informação Fonte: elaboração própria

Observa-se, também, que as etapas para o desenvolvimento do sistema de informações executivas (SIE) apresentadas, anteriormente, procuram mostrar a natureza do gerenciamento das informações estratégicas a partir do entendimento do negócio 
empresarial, do processo de gestão, das características da decisão estratégica e das peculiaridades do usuário da informação no processo decisório. Espera-se que o SIE elimine a redundância de informações, integrando as informações internas e externas, disponibilizando-as de forma amigável e rápida aos executivos no momento oportuno.

\subsubsection{Informação interna para decisão estratégica}

A seção que caracterizou a estratégia mostra que a informação permeia todas as etapas do processo de gestão estratégica, demonstrando o papel que a informação representa para a sobrevivência e sucesso das empresas.

A informação estratégica é o produto da interpretação dos dados do ambiente e de aspectos internos da organização e permite ao executivo tomar decisões sobre o produto a ser oferecido e o mercado a ser atendido melhor do que outras empresas. A informação possibilita ao executivo escolher o caminho para cumprir a missão organizacional, visando uma melhor interação com o ambiente.

A informação interna, utilizada para identificar os pontos fortes e pontos fracos, pode ser classificada em dois tipos:

- Informações sobre os recursos e capacidades organizacionais atuais - possibilitam identificar os recursos disponíveis e as habilidades da empresa para criar vantagem competitiva por meio da administração desses recursos. Os recursos representam as entradas no processo de operação da empresa (equipamentos, finanças, gerentes) “As capacidades são, freqüentemente, desenvolvidas em áreas funcionais específicas (fabricação, marketing, P\&D) ou em parte (propaganda) de uma área funcional" (HITT, IRELAND e HOSKISSON, 2002, p.111).

- Informações de resultados - acompanham o desempenho atual da estratégia implementada através dos indicadores de desempenho que irão monitorar os fatores críticos para o sucesso da empresa.

As informações mais citadas para análise dos recursos e capacidades organizacionais são (figura 10):

- Informações sobre as atividades de marketing - força de vendas, forma de distribuição, características e preços dos produtos, promoção e propaganda etc;

- Informações sobre as atividades de produção - custos, qualidade, nível de estoque, instalações, tecnologia de produção, equipamentos etc; 
- Informações sobre as atividades financeiras - análise dos índices financeiros, organização do sistema de controle financeiro e contábil, capacidade dos relatórios e demonstrativos da empresa informar seu desempenho etc;

- Informações sobre as atividades relacionadas aos recursos humanos da empresa experiência e sensibilidade dos executivos, habilidades e conhecimentos dos gerentes e funcionários, aspirações, valores e crenças de gerentes e funcionários etc;

- Informações sobre os aspectos organizacionais - Informações sobre aspectos que abrangem toda a empresa: estrutura, cultura e clima organizacional, políticas, sistema de informações etc.

\begin{tabular}{|c|c|c|}
\hline \multirow{2}{*}{$\begin{array}{c}\text { Atividades Empresariais } \\
\text { e Aspectos da } \\
\text { Organização }\end{array}$} & \multicolumn{2}{|c|}{ Informação Estratégica Interna } \\
\hline & $\begin{array}{c}\text { Sobre os Recursos e Capacidades } \\
\text { Organizacionais }\end{array}$ & Resultados das áreas-chave \\
\hline Marketing & $\begin{array}{ll}\text { - } & \text { Produto } \\
\text { - } & \text { Distribuição } \\
\text { - } & \text { Preço } \\
\text { - } & \text { Promoção }\end{array}$ & $\begin{array}{l}\text { - } \quad \text { Vendas por empregado } \\
\text { - } \quad \text { vendas efetivas comparadas às } \\
\text { - Índice de queixas dos clientes } \\
\text { - } \quad \text { Participação de mercado }\end{array}$ \\
\hline Produção & $\begin{array}{ll}\text { - } & \text { Custos } \\
\text { - } & \text { Qualidade } \\
\text { - } & \text { Instalações } \\
\text { - } & \text { Equipamentos }\end{array}$ & $\begin{array}{l}\text { - Número de novos métodos de } \\
\text { produção adotados } \\
\text { - Quantidade de trabalho corretivo }\end{array}$ \\
\hline Finanças & $\begin{array}{l}\text { - } \text { Sistema de planejamento e controle } \\
\text { - } \quad \text { Relatórios e demonstrativos } \\
\text { - } \quad \text { Análise dos índices financeiros }\end{array}$ & $\begin{array}{ll}\text { - } & \text { Índices de dívida } \\
\text { - } & \text { Faturamento } \\
\text { - } & \text { Margem líquida }\end{array}$ \\
\hline Recursos Humanos & $\begin{array}{l}\text { - } \text { Aspirações, valores e crenças do } \\
\text { dirigente e dos funcionários } \\
\text { - } \text { Habilidades de gerentes e empregados } \\
\text { - } \quad \text { Programas de treinamento } \\
\text { - } \quad \text { Plano de benefícios }\end{array}$ & $\begin{array}{l}\text { - Índice de rotatividade } \\
\text { - } \\
\text { - } \\
\text { Bealização de treinamento } \\
\text { trabalhador e incentivos ao }\end{array}$ \\
\hline Aspectos Organizacionais & $\begin{array}{ll}\text { - } & \text { Estrutura organizacional } \\
\text { - } & \text { Sistema de informações } \\
\text { - } & \text { Cultura organizacional } \\
\text { - } & \text { Políticas }\end{array}$ & $\begin{array}{l}\text { - Instrumentos de controle gerencial } \\
\text { - } \quad \text { Indicadores de clima organizacional }\end{array}$ \\
\hline
\end{tabular}

Figura 10 - Informações estratégicas disponíveis internamente na empresa Fonte: baseado em SINK e TUTTLE ${ }^{11}$ (apud BEUREN, 2000, p.89); COSTA (1999); FISCHMANN e ZILBER (1999); KOTLER (1998); OLIVEIRA (2002a); RUAS e PINHEIRO (1996)

${ }^{11}$ SINK, D. Scott; TUTLE, Thomas C. (1993). Planejamento e medição para a performance. Rio de Janeiro: Qualitymark. 
As informações de resultados são relativas ao desempenho ${ }^{12}$ da organização que serão analisados através da utilização dos indicadores de desempenho. "Um indicador tanto pode ser a informação extraída a partir dos próprios registros - registro de vendas, como também pode resultar de uma relação entre registros - faturamento/vendedores" (RUAS e PINHEIRO, 1996, p.11). Os gerentes monitoram os fatores críticos para o sucesso da organização através dos indicadores que irão sinalizar possíveis problemas ou novas oportunidades.

Os indicadores não se limitam apenas aos dados financeiros, pois, indicadores de qualidade, satisfação dos clientes, inovação e participação de mercado permitem uma radiografia melhor da situação econômica da empresa do que o lucro dos relatórios financeiros (ECCLES, 2000). Índices de defeitos, prazos de resposta, compromissos de entrega, índices de retenção dos clientes, percepção de valor dos bens e serviços etc, são indicadores que têm o propósito de mostrar o desempenho atual e perspectivas de crescimentos futuros.

Enfim, para acompanhar e avaliar a execução da estratégia, a empresa precisa ter à sua disposição um conjunto de indicadores (figura 10), sintonizados com os objetivos estratégicos, que sinalize as mudanças ocorridas nas áreas-chave de resultado e auxilie o executivo na análise do desempenho organizacional, a fim de garantir a competitividade da organização.

\footnotetext{
12 "Capacidade da empresa atingir seus objetivos estratégicos através da implementação de estratégias
} adotadas dentro do seu processo de planejamento" (FISCHMAN e ZILBER, 1999, p.2) 


\section{GESTÃO DA PEQUENA EMPRESA}

As pequenas empresas sempre existiram e exerceram um papel relevante na economia de seus países. No Brasil, as pesquisas realizadas por instituições como o SEBRAE e IBGE, têm mostrado a representatividade dessas empresas e sua importância sócio-econômica (tabelas 1 e 2), hoje amplamente divulgada na mídia.

Tabela 1 - Importância sócio-econômica das MPEs

\begin{tabular}{|l|l|}
\hline Representatividade das MPEs & Porcentagem \\
\hline Empregos com carteira assinada & $50 \%$ \\
\hline Empregos informais & $100 \%$ \\
\hline Participação no PIB & $25 \%$ \\
\hline Participação nas exportações & $2 \%$ \\
\hline
\end{tabular}

Fonte: Ramiro e Loturco (2002, p.129).

Em 1979, um estudo realizado pelo Banco do Brasil ${ }^{13}$ (apud GIMENEZ, 1988; PINHEIRO, 1996) ressaltou a importância das MPEs, conforme descrito abaixo:

- Atendimento das necessidades de consumo de grande parcela da população de baixa renda;

- Atuação fomentadora do processo de desenvolvimento das áreas periféricas;

- Fixação de renda em áreas pouco desenvolvidas, contribuindo com distribuição de riqueza e atenuando os desequilíbrios regionais;

- Função complementar a grande empresa;

- Instrumento de políticas de desconcentração espacial das atividades econômicas;

- Maior capacidade de absorção de mão de obra.

\footnotetext{
${ }^{13}$ BANCO DO BRASIL S/A. Diretoria de Planejamento. Coordenadoria de Análise Sócio Econômica (COESE). Micro, pequenas e médias empresas: uma abordagem analítica das suas dificuldades e das possíveis medidas para solucioná-las nas áreas gerenciais, de produção, de mercado, físcal e financeira. Brasília, 1979.
} 
Tabela 2 - Representatividade das MPEs nos setores de atividades (**)

\begin{tabular}{|c|c|c|c|c|}
\hline $\begin{array}{l}\text { Setor de } \\
\text { atividade }\end{array}$ & $\begin{array}{c}\text { Total de } \\
\text { Estabelecimentos } \\
\text { (A) }\end{array}$ & $\begin{array}{l}\text { Empresas de todos } \\
\text { os portes } \\
\text { (B) }\end{array}$ & $\begin{array}{c}\text { MPEs }\left(^{*}\right) \\
\text { (C) }\end{array}$ & (C)/B) \\
\hline INDÚSTRIA & 183.889 & 164.366 & 160.756 & $97,8 \%$ \\
\hline COMÉRCIO & 593.395 & 565.349 & 562.929 & $99,6 \%$ \\
\hline SERVIÇOS & 486.834 & 411.586 & 405.040 & $98,4 \%$ \\
\hline SUBTOTAL & 1.264 .118 & 1.141.301 & 1.128 .725 & $98,9 \%$ \\
\hline AGROPECUÁRIA & 218.016 & - & 184.512 & - \\
\hline TOTAL & 1.482 .134 & $\cdot$ & 1.313 .237 & - \\
\hline$\left({ }^{*}\right)$ Conceito MPE: & \multicolumn{4}{|c|}{ INDÚSTRIA - de 0 até 99 empregados } \\
\hline & \multicolumn{4}{|c|}{ COMÉRCIO - de 0 até 49 empregados } \\
\hline & \multicolumn{4}{|c|}{ SERVIÇOS - de 0 até 49 empregados } \\
\hline & \multicolumn{4}{|c|}{ AGROPECUÁRIA - de 0 até 100 hectares } \\
\hline
\end{tabular}

(**) Dados do CEE/MTE (dez/99), Censo Agropecuário (1995/96) e as MPEs.

Fonte: SEBRAE - SP (2000a, p.9).

A empresa de pequeno porte possibilita uma maior absorção de mão-de-obra, até não qualificada, forma mão-de-obra, complementa as atividades da grande empresa e permite a desconcentração espacial das atividades econômicas, distribuindo melhor a renda e ampliando a classe média (BORTOLI NETO, 1980; MINOZZI, 1987; GIMENEZ, 1988; PINHEIRO, 1996).

Apesar do reconhecimento da importância sócio-econômica da pequena empresa, pouco se faz, aqui, no Brasil, para incluir essa categoria de empresas na política econômica governamental, como poucos são os estudos desenvolvidos pelas instituições de ensino e pesquisa para o entendimento das especificidades dessas empresas que muito contribuem com a sociedade brasileira.

\subsection{Critérios para definição das pequenas empresas}

Para resolver o problema da definição do que seja uma pequena empresa, três categorias de critérios são comumente utilizadas - critérios quantitativos, critérios qualitativos e critérios mistos - por analistas e instituições governamentais na tentativa de conceituar essas unidades empresariais. Para Leone (1991), são os critérios 
quantitativos que predominam. $\mathrm{Na}$ sua opinião, a classificação por tamanho, além de revelar o comportamento econômico e social significativo das PMEs, poderá apontar soluções mais adequadas aos seus problemas, servindo também de parâmetro aos programas e ações governamentais.

Filion ${ }^{14}$ (apud PINHEIRO, 1996) ressalta que, na maioria das vezes em que se procura definir a pequena empresa, os propósitos são fiscais ou tem finalidade de abertura de linhas de crédito governamentais e privilegiadas para essa categoria de empresas.

Para Bortoli Neto (1980) parece que o melhor critério é o de definir a pequena empresa em função do objetivo a que ela se destina, utilizando-se para isso o parâmetro mais compatível com esse objetivo.

A pequeno empreendimento é definido "por uma série de características ou circunstâncias relacionadas às suas próprias peculiaridades e, muito comumente, a uma dada finalidade em relação à sua participação na economia" (PINHEIRO, 1996, p.21).

Os critérios quantitativos são econômicos e, ao conceituarem as pequenas empresas, ajudam a explicar seu comportamento social, como também os critérios qualitativos, de natureza mais social, ajudam na compreensão do seu comportamento econômico (LEONE, 1991, p.54). Na opinião da autora são os critérios econômicos que determinam o porte das empresas. Eles apresentam algumas vantagens: são de fácil coleta, possibilitando análises estatísticas de tendência temporal e análises comparativas entre as empresas, além de serem de uso corrente em todos os setores (governo, universidades e estatísticas).

Esses critérios são de muitos tipos e tocam em diferentes componentes da atividade empresarial. "O critério escolhido, e suas medidas vão depender efetivamente dos fins que se têm em vista" (LEONE, 1991, p.55). As agências de crédito e financiamento, por exemplo, irão se preocupar basicamente com as garantias reais que as empresas podem oferecer. Dessa forma, os critérios utilizados devem refletir a situação patrimonial das empresas.

Os critérios qualitativos também são largamente utilizados para definir o tamanho da empresa. "Eles apresentam uma imagem mais fiel das empresas, uma vez que tocam, essencialmente, na sua estrutura interna, na sua organização e nos estilos de gestão" (LEONE, 1991, p.57). Ou seja, esses critérios passam uma visão mais de

\footnotetext{
${ }^{14}$ FILION, Louis Jaques. Free Trade: The need for a definition of small business. Université du Québec à Trois. Riviéres, Journal of Small Business \& Entrepreneurship, v.7, n.2, p.33-45, jan/mar. 1990.
} 
movimento, de ação gerencial, mostrando a dinâmica da organização no seu dia-a-dia; por exemplo, seu relacionamento com fornecedores e clientes ou pedindo empréstimos etc. A autora ainda faz uma comparação com os critérios quantitativos dizendo que: "os critérios quantitativos dão uma imagem estática à empresa” (LEONE, 1991, p.58).

Bortoli Neto (1980) refere-se a esse critério como sendo o diferencial em relação às organizações de maior porte. Existem características distintas que são pertinentes a sua direção, pois as atribuições do dirigente, mais as relações entre a direção e a propriedade, são pontos capazes de distinguir este tipo de empreendimento. $\mathrm{O}$ número reduzido de postos diretivos, a centralização das decisões e o relacionamento direto entre dirigentes e funcionários são exemplos que ilustram a distinção entre a pequena e a grande empresa.

Estudiosos e instituições de apoio à pequena empresa também podem utilizar critérios mistos (quantitativos e qualitativos) para definir o porte das empresas. Como exemplo de critérios mistos, Leone (1991) cita o Decreto-lei nº486 de 03.03.1969 que define o pequeno comerciante pelas seguintes bases: natureza artesanal da atividade; predominância do trabalho próprio e de familiares; capital empregado e renda bruta anual.

A variedade de critérios demonstra a diversidade dos fins que se pretende alcançar, ou o ponto de vista do qual se quer estudar a pequena empresa. Os critérios quantitativos proporcionam a oportunidade de análises comparativas e estatísticas de tendência temporal e se referem a diferentes partes da atividade empresarial. Já os critérios qualitativos permitem o entendimento da dinâmica organizacional, proporcionando uma imagem fiel das empresas. Os critérios mistos normalmente são uma ligação entre os critérios qualitativos e quantitativos, eles "combinam indicadores econômicos com características sociais e políticas" (LEONE, 1991, p.59).

Independente dos critérios utilizados na definição do tamanho das empresas, o propósito é inferir o comportamento dessa categoria de empresas.

\subsection{Especificidades da pequena empresa}

Como foi visto anteriormente os critérios qualitativos permitem uma imagem mais real do funcionamento da pequena empresa, evidenciando suas especificidades que as distinguem da grande empresa. Na literatura, muitas vezes, elas aparecem como vantagens ou problemas do pequeno empreendimento. 
O entendimento dessas especificidades é o pré-requisito para que se possa contribuir com a sobrevivência e o sucesso dessa categoria de empresas. Seja em termos de política econômica governamental ou na melhoria de sua gestão. Esse entendimento possibilitará a compreensão de como o comportamento do empreendedor, a estrutura, a tecnologia, a estratégia e os fatores externos à organização interagem, moldando as ações da pequena empresa (figura 11).

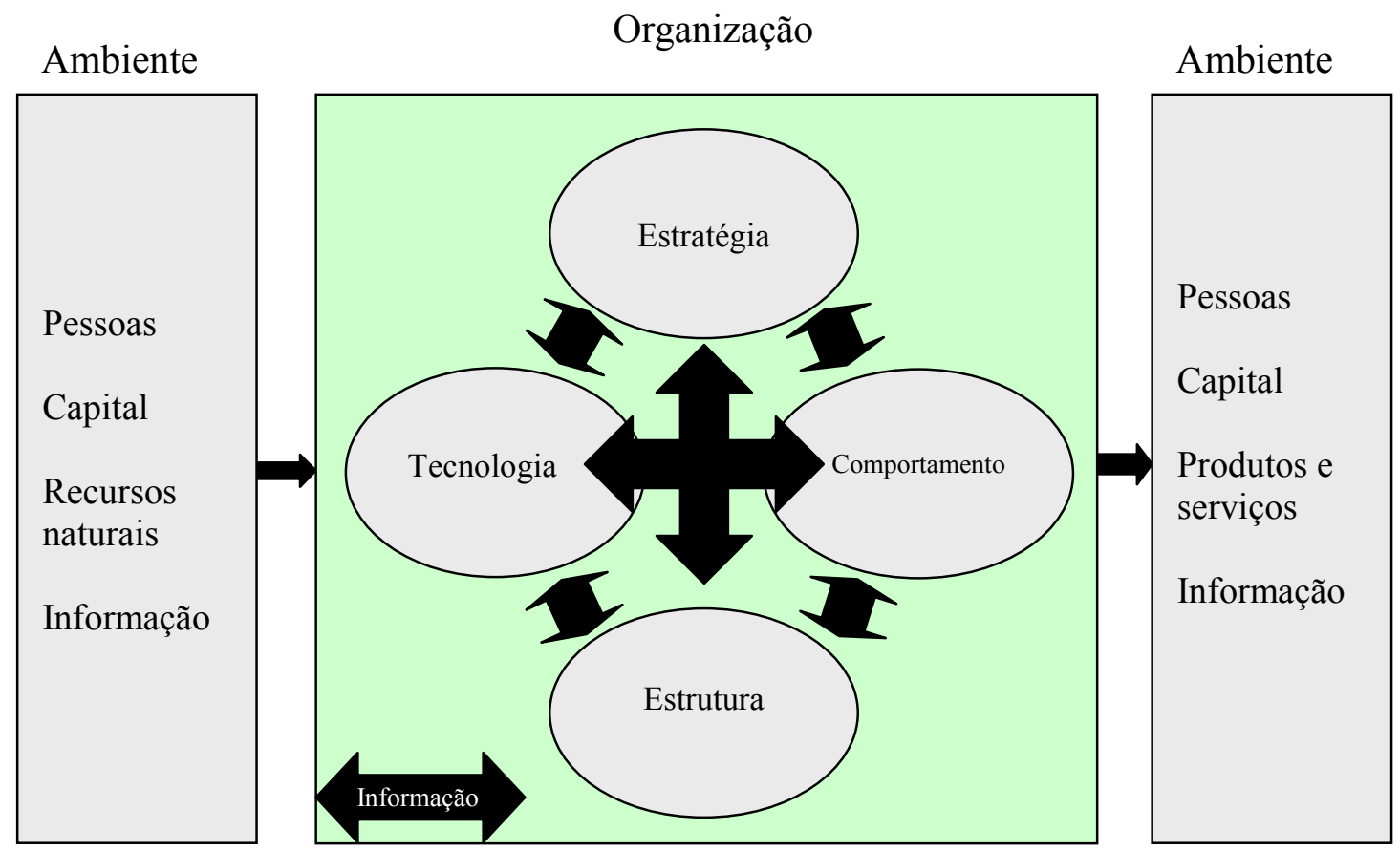

Figura 11 - Modelo de representação organizacional

Fonte: Adaptado de Nadler e Tushman (1994)

O modelo de representação organizacional (ASHKENAS, 1997; ESCRIVÃO FILHO, 1998; LEAVITT, 1978; NADLER e TUSHMAN, 1994) mostra as dimensões ambiental e organizacional, e a inter-relação entre quatro componentes organizacionais e o seu ambiente.

\subsubsection{Dimensão ambiental}

O ambiente impõe limitações à pequena empresa, influenciando suas ações e decisões. As especificidades ambientais (figura 12) são condicionadas pelas forças do ambiente da empresa (ou ambiente externo) e buscam explicar essas limitações.

O ambiente da empresa normalmente é dividido em dois segmentos: o macroambiente e o ambiente operacional (VASCONCELOS FILHO, 1983; CERTO e PETER, 1993; BATEMAN e SNELL, 1998; KOTLER, 1998; MAXIMIANO, 2000a). 
No macroambiente, encontram-se as forças demográficas, econômicas, tecnológicas, políticas, legais, sociais, culturais, entre outras. Essas forças "afetam a maioria das organizações, ou todas as organizações que compartilhem algo, tal como os mesmos clientes, ou a mesma tecnologia” (MAXIMIANO, 2000a, p.382).

Segundo Maximiano (2000a, p.382) "o ambiente operacional compreende outras organizações, pessoas e outros tipos de fatores que afetam ou são afetados diretamente pela organização".

Para Almeida (2001), no ambiente operacional, estão as variáveis decorrentes das operações. As variáveis mais importantes, entre outras, são: clientes, concorrentes, fornecedores, associações de classe.

\begin{tabular}{|c|c|c|}
\hline DIMENSÃO & SEGMENTOS & ESPECIFICIDADES \\
\hline \multirow[t]{2}{*}{ AMBIENTAL } & 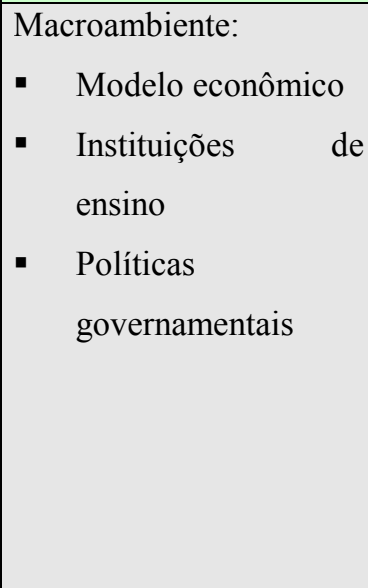 & $\begin{array}{l}\text { - Ocupante dos espaços pré-determinados pela } \\
\text { estrutura produtiva; } \\
\text { - Fornecedora de produtos populares de baixo } \\
\text { preço (baixa rentabilidade) ou dirigidos a uma } \\
\text { pequena parcela da classe A; } \\
\text { - Empregadora de "administradores deslocados"; } \\
\text { - Carente de apoio dos organismos } \\
\text { governamentais; } \\
\text { - Submissa à excessiva carga tributária e } \\
\text { complexidade da legislação fiscal. }\end{array}$ \\
\hline & $\begin{array}{l}\text { Ambiente operacional: } \\
\text { - Concorrentes } \\
\text { - } \quad \text { Fornecedores } \\
\text { - Clientes }\end{array}$ & $\begin{array}{l}\text { - Compete em condições adversas com a grande } \\
\text { empresa; } \\
\text { - Pouca margem de negociação com fornecedores } \\
\text { e clientes. }\end{array}$ \\
\hline
\end{tabular}

Figura 12 - Especificidades ambientais da pequena empresa

Fonte: elaboração própria

\subsubsection{Especificidades ambientais da pequena empresa}

Várias são as limitações impostas pela estrutura produtiva (força do macroambiente) à pequena empresa:

- Atuam nos limites do mercado, fornecendo produtos populares de baixo preço (baixa rentabilidade) ou produtos dirigidos a uma pequena parcela da população (classe A) que não possui economias de escala (MINOZZI, 1987).

- Florescem em mercados restritos ou específicos que não apresentam atratividade econômica para grandes empresas (GIMENEZ, 1988). 
- São incapazes de exercer qualquer controle sobre os acontecimentos futuros do setor de atuação (GOLDE, 1986).

Além das limitações impostas pela estrutura produtiva e da opressão das grandes organizações, as PMEs são influenciadas pela excessiva carga tributária, pela complexidade das obrigações fiscais, pelo difícil acesso às fontes de financiamentos (tabela 3), além dos juros excessivos (CAVALCANTI, FARAH e MELO, 1981; MINOZZI, 1987; GIMENEZ, 1988; PINHEIRO, 1996) e pela inadequação da teoria administrativa ensinada nas instituições de ensino (BORTOLI NETO, 1980).

Para Minozzi (1987) a obtenção de empréstimo pelas PMEs é inviabilizada pelos riscos do crescimento descontínuo associado aos altos custos financeiros. Como as empresas têm baixa rentabilidade, os lucros são insuficientes para o pagamento dos juros dos financiamentos. Ainda segundo o autor a economia invisível ${ }^{15}$ é um fenômeno mundial que funciona como escudo para a pequena empresa se proteger da política econômica e da alta carga tributária imposta pelo governo.

Tabela 3 - Formas de financiamento utilizadas pelas MPEs

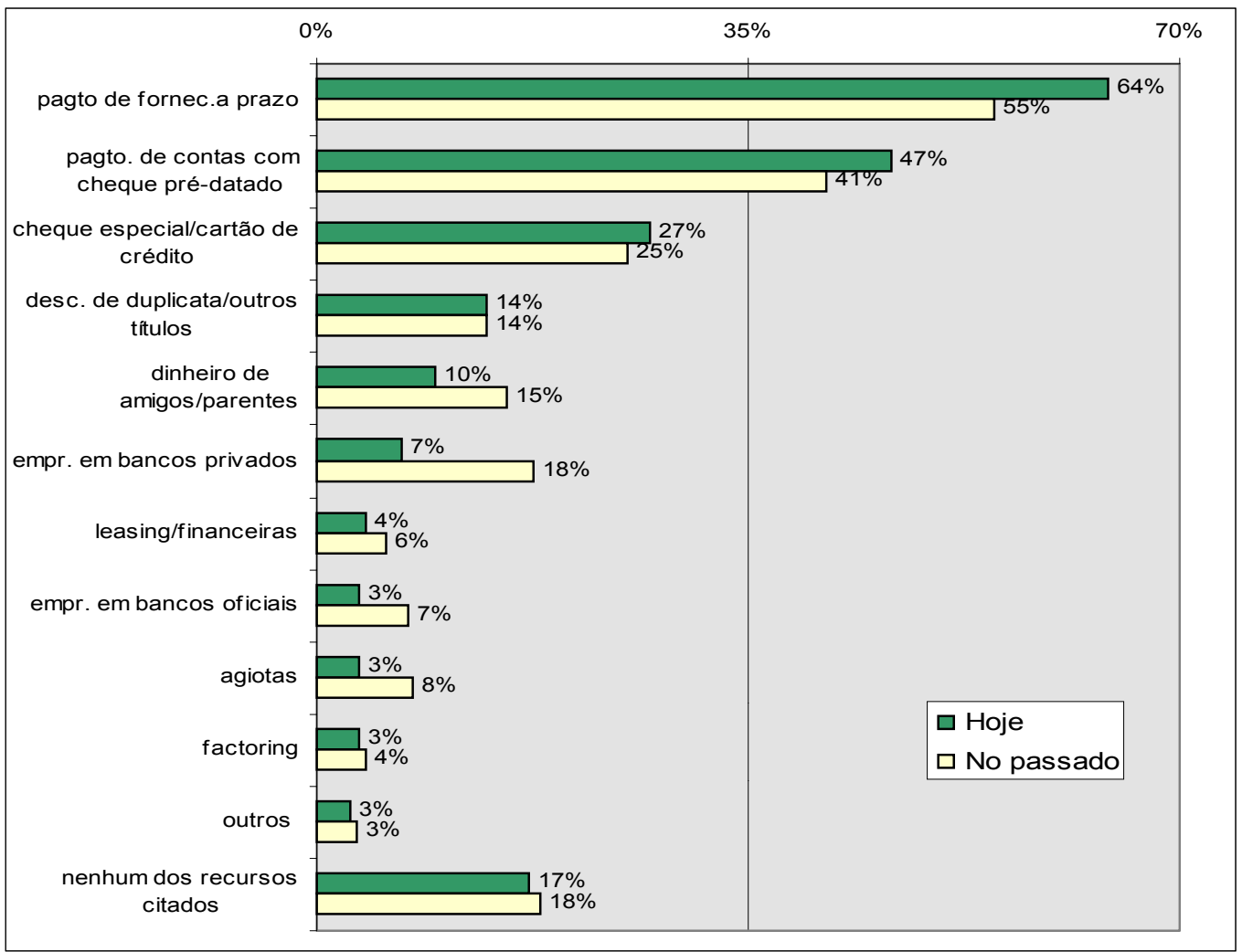

Fonte: Sebrae-SP/Fipe (1999, p.3)

\footnotetext{
${ }^{15}$ Empresas operando na clandestinidade sem pagar impostos.
} 
Os resultados da Pesquisa (tabela 3) realizada pelo SEBRAE sobre formas de financiamento nas MPEs do Estado de São Paulo demonstram o baixo índice de captação de recursos pelos empresários em instituições financeiras. $\mathrm{O}$ autofinanciamento aparece como a alternativa mais viável.

\subsubsection{Dimensão organizacional: componente estrutura}

A estrutura é uma componente organizacional e apresenta características típicas na pequena empresa. As especificidades (figura 13) estão relacionadas com o processo de organização da empresa: a divisão do trabalho, a delegação de autoridade e forma de comunicação entre os seus integrantes.

\begin{tabular}{|c|c|c|}
\hline COMPONENTE & CARACTERÍSTICAS & ESPECIFICIDADES \\
\hline \multirow{3}{*}{ Estrutural } & $\begin{array}{l}\text { - Divisão de trabalho e } \\
\text { de recursos }\end{array}$ & $\begin{array}{l}\text { Poucas unidades de trabalho } \\
\text { (cargos, seções etc); } \\
\text { - Maior escopo de cargo para a } \\
\text { função de direção; } \\
\text { - Mínima preocupação com os } \\
\text { requisitos de um cargo. }\end{array}$ \\
\hline & $\begin{array}{lll}\text { - } & \text { Sistema } & \mathrm{de} \\
\text { Autoridade } & \end{array}$ & $\begin{array}{l}\text { - } \text { Autoridade centralizada; } \\
\text { Maior amplitude e facilidade } \\
\text { de controle; } \\
\text { - Pouco ou nenhum nível de } \\
\text { autoridade (hierarquia). }\end{array}$ \\
\hline & $\begin{array}{l}\text { Forma } \\
\text { comunicação }\end{array}$ & 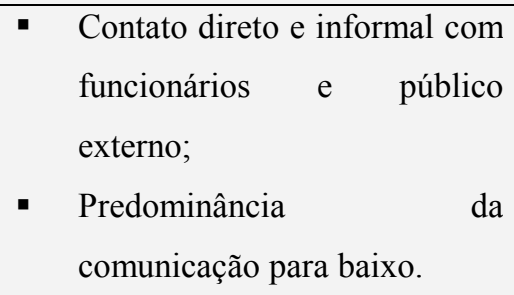 \\
\hline
\end{tabular}

Figura 13 - Especificidades estruturais da pequena empresa Fonte: elaboração própria

A divisão do trabalho corresponde à atribuição da tarefa a uma pessoa ou grupo de pessoas. Há três aspectos principais que são considerados: a definição de 
responsabilidades de tarefas, as unidades de trabalho e a especialização resultante da divisão do trabalho (MAXIMIANO, 2000b).

O resultado da divisão do trabalho forma as unidades de trabalho. Essas unidades (cargos, departamentos, seções etc) integradas irão formar a estrutura organizacional. As tarefas atribuídas a pessoas irão formar os cargos e as atribuídas a um grupo de pessoas formarão os departamentos. Normalmente, um departamento é um agregado de cargos e responsável por uma função ou conjunto de funções (marketing, finanças etc). Para ocupar os cargos são exigidos alguns requisitos (qualificações necessárias ao desempenho) do seu ocupante (MAXIMIANO, 2000b).

A divisão do trabalho também produz especialização (MAXIMIANO, 2000b). Quanto maior for o escopo de um cargo, menos especializado é o seu ocupante.

Autoridade é a formalização (institucionalização) do poder (HAMPTON, 1992, p.276). É o direito legal que os chefes têm de influenciar o comportamento de seus subordinados e comprometer os recursos organizacionais (MAXIMIANO, 2000b). Essa autoridade é distribuída em níveis e representa a hierarquia na empresa. Os níveis hierárquicos irão definir a amplitude de controle ${ }^{16}$ de cada gerente.

O grau de centralização ou descentralização é outra importante decisão no exercício da autoridade. Numa empresa centraliza, a autoridade está concentrada nos níveis superiores. Uma das vantagens da centralização é a uniformidade e a facilidade de controle. Em compensação a centralização tende a inibir a iniciativa e desestimular a criatividade dos funcionários (MAXIMIANO, 2000b).

A forma de comunicação é outro aspecto estudado no delineamento da estrutura organizacional. É através desse processo que o gerente vai integrar todas as partes da estrutura organizacional e acompanhar seu desempenho. "Comunicação é o processo de transferir e receber informações". É o ingrediente que possibilita o funcionamento coordenado da estrutura (MAXIMIANO, 2000b, p.282).

Há três tipos de comunicação em uma estrutura organizacional: para baixo utilizada pela direção para informar as expectativas da administração em relação aos funcionários; para cima - informar a gerência sobre o desempenho organizacional e eventos ocorridos na empresa; e lateral - que não segue os níveis formais de hierarquia, acontecendo em todos os sentidos (MAXIMIANO, 2000b).

\footnotetext{
${ }^{16} \mathrm{O}$ número de funcionários subordinados a um gerente.
} 


\subsubsection{Especificidades estruturais da pequena empresa}

A pequena empresa possui poucas unidades de trabalho, sua estrutura é enxuta se comparada com as grandes empresas (PINHEIRO, 1996). Por isso são mais ágeis e flexíveis para se adaptarem às novas situações impostas pelo ambiente.

Os requisitos para ocupar o cargo, na maioria das vezes, são deixados de lado. Normalmente, a pequena empresa contrata mão-de-obra não qualificada e remunera precariamente, devido aos escassos recursos financeiros, ou forma a própria mão-deobra (BORTOLI NETO, 1980; MINOZZI, 1987; GIMENEZ, 1988; PINHEIRO, 1996).

Também, é típico da pequena empresa a pouca especialização do dirigente, quando ele tem muitas responsabilidades e tem de realizar uma grande quantidade de tarefas. O dirigente precisa se ocupar de quase todas as áreas funcionais (GOLDE, 1986).

Na pequena empresa a autoridade é centralizada, as principais decisões são exclusivas do proprietário-dirigente, existindo um insignificante grau de delegação e descentralização administrativa (BORTOLI NETO, 1980; CAVALCANTI, FARAH e MELO, 1981; LEONE, 1999; PINHEIRO, 1996) que é desejável pelo empresário devido à pouca disponibilidade de recursos e incertezas vindas do ambiente.

Pela simplicidade de sua estrutura ${ }^{17}$ a pequena empresa utiliza prioritariamente a comunicação pessoal através da conversação individual com funcionários e clientes. Esse contato direto é apontado como uma das principais vantagens da pequena empresa (BORTOLI NETO, 1980; CAVALCANTI, FARAH e MELO, 1981; MINOZZI, 1987; LEONE, 1999).

Esse contato direto com funcionários e clientes propicia calor humano, levando a um melhor relacionamento que possibilita atendimento individualizado ou tratamento de forma diferenciada.

\subsubsection{Dimensão organizacional: componente comportamento}

As características comportamentais do dirigente são uma componente organizacional e apresenta características típicas na pequena empresa. As especificidades (figura 14) estão relacionadas às características do pequeno empresário,

\footnotetext{
${ }^{17}$ As organizações podem ser simples, quando apresentam características de um número limitado de níveis hierárquicos, pouca especialização e a possibilidade de contatos imediatos entre todos os membros da entidade (KWASNICKA, 1995).
} 
refletindo seus valores, atitudes, desejos, motivações, competências, experiências, estilo de liderança etc, nas ações e decisões tomadas. Elas buscam explicar o comportamento do dirigente da pequena empresa.

As características individuais ajudam a entender as pessoas e seu comportamento, como indivíduos e membros de grupos nas organizações (MAXIMIANO, 2000a e 2000b).

As atitudes "são declarações de avaliação - tanto favoráveis quanto desfavoráveis - a respeito de objetos, pessoas ou eventos. Elas refletem a forma como um indivíduo se sente em relação a alguma coisa" (ROBBINS e COULTER, 1998, p.291).

Segundo Kotler (1998, p.176), "a crença é um pensamento descritivo que a pessoa sustenta sobre algo". Normalmente, são baseadas no conhecimento, na opinião ou na fé.

As competências "são as qualificações que uma pessoa deve ter para ocupar um cargo e desempenhá-lo eficazmente" (MAXIMIANO, 2000b, p.41). As competências de um gerente irão depender do nível hierárquico, das tarefas, do tipo de organização etc. $\mathrm{O}$ autor classifica-as em três categorias: conhecimentos, habilidades e atitudes.

Os conhecimentos incluem todas as informações e técnicas que o gerente deve dominar e que são necessárias ao desempenho do cargo. "Os conhecimentos funcionam como pontos de referência para compreensão da realidade e como base para o desenvolvimento das habilidades" (MAXIMIANO, 2000b, p.41).

As habilidades são as competências para o desempenho das tarefas. KATZ (1986) classificou as habilidades em três categorias: técnica - relacionada com o conhecimento especializado das técnicas administrativas; humana - capacidade de compreender as pessoas e conceitual - capacidade de compreender e lidar com a complexidade organizacional.

Outra variável importante na análise da influência do comportamento do dirigente nas ações e decisões são os traços de sua personalidade. "O conceito de personalidade abrange todos os traços de comportamento e características fundamentais de uma pessoa que permanece com a passagem do tempo e que explica as reações às situações do dia-a-dia”. Demonstra como e por que as pessoas funcionam (FURNHAM 18 apud MAXIMIANO, 2000a, p.286).

\footnotetext{
${ }^{18}$ FURNHAM, Adrian. Personality at Work. Londres: Routledge, 1992. p.13-14.
} 
Normalmente, a personalidade é descrita como autoconfiança, domínio, autonomia, adaptabilidade, sociabilidade (KOTLER, 1998). Para Robbins e Coulter (1998, p.293), “quando descrevemos as pessoas utilizando termos como calma, passiva, agitada, ambiciosa, leal, extrovertida..., nós as estamos categorizando em termos de traços de personalidade", ou seja, é usada uma combinação de traços psicológicos para descrever o indivíduo.

Kotler (1998) afirma também que o autoconceito (ou auto-imagem) está relacionado à personalidade de uma pessoa. É a maneira como o dirigente quer se ver ou gostaria de ser visto, repassando esta imagem para a empresa.

O estilo de liderança do dirigente também exercerá influência nas decisões da empresa. "A liderança é uma função, papel, tarefa ou responsabilidade que qualquer pessoa precisa desempenhar, quando é responsável pelo desempenho de um grupo" (MAXIMIANO, 2000a, p.331). Para McGREGOR (1980) a liderança não é apenas atributo da pessoa, mas uma relação completa entre quatro variáveis: (1) características do líder, (2) características dos liderados, (3) características da organização (finalidades, estrutura e natureza das atividades) e (4) ambiente social, econômico e político

O líder pode apresentar três tipos de comportamento: autocrático - concentração da autoridade e decisões que independem de participação dos liderados; democrático influência dos liderados na decisão tomada pelo líder; liberal - abdicação do líder de seu poder de tomar decisões (MAXIMIANO, 2000b).

\begin{tabular}{|c|c|c|}
\hline COMPONENTE & CARACTERÍSTICAS & ESPECIFICIDADES \\
\hline \multirow{4}{*}{ Comportamental } & - Estilo de liderança & - Comportamento autocrático. \\
\hline & $\begin{array}{|ll|}- & \text { Traços } \\
& \text { Personalidade }\end{array}$ & $\begin{array}{l}\text { Dirigentes autoconfiantes, autônomos, com } \\
\text { vontade de realizar e que corre risco. }\end{array}$ \\
\hline & - Competências & $\begin{array}{l}\text { - Pouco conhecimento de gestão; } \\
\text { - Pouca Capacidade de entendimento da } \\
\text { complexidade organizacional. }\end{array}$ \\
\hline & - $\quad$ Crenças e Atitudes & $\begin{array}{l}\text { - Confiança apenas na capacidade empreendedora } \\
\text { individual; } \\
\text { - Indiferença às técnicas de gestão. }\end{array}$ \\
\hline
\end{tabular}

Figura 14 - Especificidades comportamentais do dirigente da pequena empresa Fonte: elaboração própria 


\subsubsection{Especificidades comportamentais do dirigente da pequena empresa}

As especificidades relacionadas com as competências administrativas são as mais citadas na literatura. São mencionadas quase sempre, como um problema, a gestão da pequena empresa, devido ao pouco conhecimento das técnicas de gestão por parte do proprietário-dirigente. Algumas dessas menções são citadas abaixo e ilustram como essa característica se manifesta na pequena empresa.

Minozzi (1987) afirma que o dirigente não domina a tecnologia organizativa da PME. E os poucos que buscam cursos escolares são treinados para trabalhar em grandes organizações. O que Covre ${ }^{19}$ (apud MINOZZI, 1987) chamou de "administradores deslocados", pois os conceitos aprendidos na escola são úteis à grande empresa, mas a atuação é na empresa de pequeno porte.

Para Bortoli Neto (1980) o empresário de PME costuma ter dificuldade em identificar o que é problema ou sintoma, assim como idealizar e operacionalizar as soluções. Constantemente, ele depara-se com problemas e não sabe defini-los com precisão, sendo a solução uma tarefa desgastante e de resultados pouco significativos. A deficiência de capital de giro normalmente é considerada um problema pelos empresários, e não um sintoma, fruto da má aplicação dos recursos disponíveis.

Na opinião de Pinheiro (1996) o proprietário-dirigente não dispõe de uma consciência administrativa, faltando-lhe uma postura empreendedora para administrar o negócio. Esses dirigentes precisam ter a noção da realidade administrativa de suas empresas e percepção dos benefícios, conveniência e alcance da utilização de técnicas gerenciais básicas, pairando uma improvisação sobre a gestão desses empreendimentos (PINHEIRO, 1996).

Pela opinião dos três autores observa-se que o pouco conhecimento de gestão do empresário é uma especificidade que afeta a sobrevivência da empresa. Entretanto é necessário entender que dois outros fatores contribuem para este fato: a atitude que os proprietários-dirigentes tem em relação à teoria administrativa e a pouca quantidade de escolas que preparam administradores para gerenciar este tipo de empreendimento.

Outra característica importante na análise da influência do comportamento do dirigente nas ações e decisões na pequena empresa relaciona-se aos traços de sua personalidade.

\footnotetext{
${ }^{19}$ COVRE, Maria de Lourdes Manzini. A formação e a ideologia do administrador de empresas. Rio de Janeiro: Vozes, 1981 - p.102.
} 
Algumas dessas descrições estão relacionadas às características apresentadas por Matias e Lopes Jr. (2002, p.4-5) para descrever o perfil do empreendedor que normalmente é o dirigente do pequeno empreendimento. É independente, seguro e confiante na execução de sua atividade profissional; tem desejo de poder; corre risco; confia em si mesmo; não depende dos outros para agir; é tenaz, firme e resistente ao enfrentar dificuldades etc.

Outras especificidades da pequena empresa citadas na literatura e relacionadas com a personalidade do proprietário-dirigente são: personalização da gestão; predominância do dirigente que corre risco; operação da empresa à imagem e semelhança do empreendedor; nascimento, vida e desenvolvimento da empresa a partir do talento, sensibilidade e vontade de realizar do empreendedor (BORTOLI NETO, 1980; LEONE, 1999). O pequeno empresário pode acreditar também, que sua capacidade empreendedora é suficiente para o negócio crescer e ter sucesso.

Quanto ao estilo de liderança, na pequena empresa, são encontradas situações relacionadas principalmente ao comportamento autocrático: as decisões são tomadas pelos dirigentes, sem a participação de importantes colaboradores que atuam no processo (PINHEIRO, 1996).

Como foi visto, anteriormente, o estilo de liderança depende de outros fatores além das características do líder. Dessa forma, fatores como mão-de-obra com baixa qualificação contribuem para o exercício deste tipo de comportamento. Ao mesmo tempo em que decide tudo sozinho, em decorrência de fatores internos e externos à organização, o proprietário-dirigente é paternalista, otimista e dedicado, motivando os que estão ao seu redor.

\subsubsection{Dimensão organizacional: componente estratégia}

A estratégia é uma componente organizacional e apresenta características típicas na pequena empresa. As especificidades (figura 15) estão relacionadas às seguintes características: utilização da técnica de planejamento estratégico, visão externa à empresa, visão interna da empresa, visão ampla do planejamento, responsabilidade pelo planejamento estratégico, formalidade do processo de formulação de estratégias e a disponibilidade de informações. 
O planejamento estratégico é um conjunto de atividades (processo) para elaborar o plano estratégico (estratégia), conforme descrito no capítulo 2. O planejamento estratégico possui um certo número de características distintivas (HAMPTON, 1992):

- Exige uma visão, externa à empresa, de oportunidades e ameaças. Para que a empresa consiga uma posição vantajosa é preciso examinar o ambiente de forma a conhecer o comportamento de suas forças e as possíveis implicações;

- Exige que se olhe dentro da empresa à procura de forças e fraquezas. A garantia de uma posição vantajosa no ambiente passa pelo diagnóstico dos pontos fortes e fracos em relação aos concorrentes;

- Exige uma visão demorada. "O planejamento estratégico implica ter uma visão ampla e extensa", embora varie de empresa para empresa o tempo adequado dos planos (HAMPTON, 1992, p.202);

- Normalmente é de responsabilidade da alta administração, mas abrange toda a organização. A maioria das vezes apenas o alto escalão possui a visão necessária e a informação para planejar para toda a empresa. Embora o planejamento seja de responsabilidade da alta administração, "a mentalidade estratégica pode disciplinar e guiar o planejamento em todos os níveis da empresa, inclusive naquele dos empregados não-supervisores" (HAMPTON, 1992, p.204).

\begin{tabular}{|c|c|c|}
\hline COMPONENTE & CARACTERÍSTICAS & ESPECIFICIDADES \\
\hline \multirow{4}{*}{ Estratégia } & $\begin{array}{ll} & \text { Horizonte do } \\
\text { planejamento }\end{array}$ & Foco no curto prazo. \\
\hline & $\begin{array}{lll} & \text { Visão } \\
\text { interna } & & \\
& & \\
\end{array}$ & $\begin{array}{l}\text { - Pouca orientação para descoberta de } \\
\text { oportunidades e ameaças e pontos fortes e } \\
\text { pontos fracos; } \\
\text { - Comportamento reativo ao ambiente. }\end{array}$ \\
\hline & $\begin{array}{l}\text { Formalidade } \\
\text { processo }\end{array}$ & $\begin{array}{l}\text { - Informalidade no processo de formulação da } \\
\text { estratégia. }\end{array}$ \\
\hline & $\begin{array}{l}\text { Disponibilidade de } \\
\text { informações }\end{array}$ & - Carência de informações internas e externas. \\
\hline
\end{tabular}

Figura 15 - Especificidades estratégicas da pequena empresa

Fonte: elaboração própria

Outro aspecto importante para caracterizar o planejamento estratégico é a formalidade do processo de formulação das estratégias. Corresponde à documentação 
escrita (metodologias) na empresa para elaboração e divulgação do plano estratégico. Um plano escrito e divulgado em toda a empresa possui alto grau de formalidade.

Para um planejamento estratégico eficaz, outro aspecto a ser considerado é a disponibilidade de informações aos planejadores. "Uma grande parte das causas do fracasso dos planos - e de certo descrédito em relação à função de planejamento - está precisamente no fato de que se planeja sem a devida consideração das informações importantes", resultando em objetivos incorretos ou em insuficiência de recursos (MAXIMIANO, 2000b, p.196).

\subsubsection{Especificidades estratégicas da pequena empresa}

A pequena empresa, devido às suas especificidades de tamanho, estrutura, cultura e limitações de recursos, apresenta obstáculos a elaboração do plano estratégico (HAYASHI, NAKAMURA E ESCRIVAÕ FILHO, 1995).

Para Golde (1996), a tendência das pequenas empresas em esquivar-se do planejamento está relacionada principalmente: ao escasso tempo do empresário, que precisa ocupar-se de quase todas as áreas funcionais, pela limitação de funcionários e recursos para contratação; pelo pouco conhecimento da técnica de planejamento que o dirigente (normalmente o fundador) possui e porque, para a pequena empresa, planejar significa manipular grandes incertezas sobre as quais ela não tem domínio.

Para Leone (1999), a incerteza percebida pela falta de informação do ambiente externo reflete sobre a estrutura organizacional, afetando o comportamento estratégico das PMEs. Esse fato faz com que o dirigente centralize as decisões em virtude do risco de ocorrer grandes perdas pela delegação da autoridade. Dessa forma, ele decide de acordo com a sua experiência e intuição (sensibilidade), onde os dados imprescindíveis à análise da tomada de decisão nem sempre estão disponíveis. A conseqüência da falta de planejamento é a empresa operar reagindo e se adaptando ao ambiente (GIMENEZ, 1988; LEONE, 1999).

Quando a pequena empresa planifica, uma característica básica do processo é a informalidade (GOLDE, 1996; HAYASHI, NAKAMURA E ESCRIVÃO FILHO, 1995, LEONE, 1999). Os detalhes são imprecisos e genéricos, não utilizando a comunicação por escrito, mas preferindo as verbais. Segundo Golde (1996, P.12), “a inclinação para a informalidade é em parte explicada pelo simples fato de que escrever e calcular detalhes toma tempo", que parece um desperdício quando se concentra no curto prazo. $\mathrm{O}$ autor relaciona também a característica da informalidade, a falta de utilização 
de técnicas matemáticas no planejamento das pequenas empresas. Leone (1999) explica também que em decorrência da informalidade, a estratégia é intuitiva, e além do mais, os funcionários estão próximos ao dirigente que pode lhes explicar a mudança de direção.

Golde (1986, p.12-3) cita também a tendência do planejamento focar-se no futuro próximo: "Tanto o medo de planificar como seu caráter informal contribuem, é claro, para isso". E que, “o planejamento é normalmente usado para livrar a pequena empresa de uma dificuldade do momento e não para evitar futuros problemas".

\subsubsection{Dimensão organizacional: componente tecnologia}

A tecnologia é uma componente organizacional e apresenta características típicas na pequena empresa. As especificidades (figura 16) estão relacionadas às carac terísticas da tecnologia de processamento de consumidores, das inovações tecnológicas e da tecnologia da informação. A tecnologia pode ser definida como as ferramentas, técnicas, equipamentos e ações para transformar insumos em bens e serviços (produtos) de forma a alcançar os objetivos organizacionais (DAFT, 2002; ROBBINS \& COULTER, 1998). Correspondem as máquinas e atividades utilizadas para processar os insumos (matéria-prima, informação etc), resultando em bens e serviços.

\begin{tabular}{|c|c|c|}
\hline COMPONENTE & CARACTERÍSTICAS & ESPECIFICIDADES \\
\hline \multirow[t]{2}{*}{ Tecnologia } & $\begin{array}{lll}\text { - } & \text { Tecnologia } & \text { de } \\
\text { processamento e } & \text { da } \\
\text { informação } & & \end{array}$ & $\begin{array}{l}\text { - Tecnologia simples; } \\
\text { - Predominância de equipamentos, técnicas e } \\
\text { processos de produção, em sua maioria, } \\
\text { obsoletos; } \\
\text { - Insuficiência de recursos tecnológicos. }\end{array}$ \\
\hline & $\begin{array}{ll} & \text { Inovações } \\
& \text { tecnológicas }\end{array}$ & $\begin{array}{l}\text { - Menor probabilidade de produzir inovações } \\
\text { radicais; } \\
\text { Maior possibilidade de produzir inovações } \\
\text { incrementais. }\end{array}$ \\
\hline
\end{tabular}

Figura 16 - Especificidades tecnológicas da pequena empresa

Fonte: Elaboração própria

Para Maximiano (2000b), tecnologia é conhecimento transformado em produtos. Kruglianskas (1996, p.13) amplia esta definição dizendo que tecnologia "é o conjunto de conhecimentos necessários para se conceber, produzir e distribuir bens e serviços de forma competitiva”. Esta definição apresenta duas implicações: a tecnologia abrange 
toda a empresa e é utilizada para agregar valor aos produtos, proporcionando vantagem competitiva.

Nas operações de processamento de consumidores são considerados três tipos de interação entre consumidores e tecnologia: 1) onde não existe nenhuma interação entre consumidores e tecnologias; 2) onde existe interação passiva; 3 ) onde existe interação ativa entre consumidores e tecnologias. No primeiro tipo o consumidor não usa, diretamente, a tecnologia, como uma operação de check in no aeroporto. No segundo tipo os consumidores estão em contato com a tecnologia, mas seu papel é passivo, como, no caso de operações de transporte aéreo, são passageiros do avião. No terceiro tipo, os consumidores utilizam ativamente a tecnologia, como no caso de utilizar as facilidades de entretenimento do avião.

As tecnologias que processam informação incluem qualquer dispositivo que colete, manipule, armazene ou distribua informação" (SLACK, 1999, p.188). Essas tecnologias incluem: computadores, periféricos, impressoras, dispositivos transmissores e receptores, antenas parabólicas, telefones, fax, programas e sistemas (SLACK, 1999). A TI pode ser aplicada: em operações (SPT, depósito de dados); como um recurso empresarial (sistemas de informações); e como arma estratégica - interna (rede, intranets, ERP) e externas - (extranets, intercâmbio eletrônico de dados, comércio eletrônico, estrutura de rede) (DAFT, 2002).

As inovações tecnológicas ocorrem quando surge um novo produto ou processo no mercado. "É uma mudança na tecnologia, uma forma nova de fazer algo" (MAXIMIANO, 2000b, p.102). A inovação "é o processo de tornar uma invenção rentável para a empresa” (KRUGLIANSKAS, 1996, p.17). As inovações são classificadas em três categorias: incrementais - pequenas melhorias efetuadas; radicais - mudanças drásticas na situação vigente e complexas - resultantes de processos longos e dispendiosos (KRUGLIANSKAS, 1996).

Quando se verifica o nível de domínio da tecnologia por uma empresa observase a sua capacidade "para utilizar o conhecimento, para adaptá-lo às novas situações que surgem e para aperfeiçoá-lo a fím de manter a competitividade da empresa" (KRUGLIANSKAS, 1996, p.16).

\subsubsection{Especificidades tecnológicas da pequena empresa}

As PMEs desenvolvem produtos, mas aplicam poucos recursos na área de P\&D e poucas pessoas estão envolvidas com o desenvolvimento de novos produtos. 
Entretanto, a pouca atenção ao setor de $\mathrm{P} \& \mathrm{D}$ pode estar relacionado ao problema de escala, "pois não há volume suficiente de vendas para custear o desenvolvimento de novos produtos e processos" (KRUGLIANSKAS, 1996, p.10). Para o autor, a maior parte das PMEs de setores tradicionais não terá condições de produzir inovações radicais, mas a gestão através da inovação incremental poderá criar condições competitivas no seu mercado de atuação.

Segundo Rothwell \& Zegveld ${ }^{20}$ (apud KRUGLIANSKAS, 1996), algumas vantagens e desvantagens podem ser citadas para inovatividade das PMEs quando comparadas às grandes empresas. Possíveis vantagens: em marketing, no dinamismo empresarial e administrativo e nas comunicações internas. As desvantagens são: escassez de mão-de-obra especializada e sistemas de comunicações externas.

As PMEs não dispõe de processos automatizados (MINOZZI, 1987, p.32). Utilizam tecnologia simples, facilitando um ajuste mais rápido ao meio social; "os equipamentos, as técnicas e os processos de produção são, na maioria, obsoletos e acarretam custos operacionais excessivos e baixa qualidade dos produtos" (CAVAlCANTI, FARAH e MELO, 1981, p.20). Para Pinheiro (1996) e Bortoli Neto (1980) as PMEs apresentam insuficiência de recursos tecnológicos. A diferença tecnológica que distancia a pequena da grande empresa é um grande desafio.

\subsection{Gerenciamento estratégico da informação na pequena empresa}

Após o estudo das especificidades que influenciam as ações e decisões na pequena empresa, observa-se que as decisões normalmente são tomadas com base na intuição e experiência do empresário dirigente. Essas características típicas demonstram em parte por que muitas empresas de pequeno porte encerram suas atividades antes de completar um ano de vida. Dessa forma, o dirigente da pequena empresa precisa se conscientizar que o gerenciamento das informações internas e externas na empresa aumenta a possibilidade de sobrevivência e sucesso do negócio.

\subsubsection{Proposta apresentada por MORAIS (1999)}

Para a autora os processos para desenvolver um sistema de informação estratégica, que ela chama de sistema de inteligência competitiva (SIC), devem

${ }^{20}$ ROTHWELL, R.; ZEGVELD, W. (1978). Small and Medium Sized Manufacturing Firms: Their Role and Problems in Innovation-Government Policy in Europe, the U.S.A, Canada, Japan and Israel, Report to the Six Countries Programme on Innovation, TNO, Delft, Netherlands. 
considerar o porte das empresas e o componente custo, pois, os empreendedores de pequeno porte apresentam algumas peculiaridades:

- Não estão conscientes da importância do gerenciamento da informação;

- Não dispõem de recursos financeiros para criar unidades especializadas em informação nas suas empresas;

- Não dispõem de tecnologias e de cultura do uso da informação;

- São consumidores de informação ofertados por empresas de pesquisa.

Dessa forma, ela propõe como forma de viabilizar o SIE, a associação entre empresas em caráter setorial, por segmento ou abrangência regional. O modelo sugerido de SIE deve atender a um grupo significativo de empresas onde serão compartilhados custos, benefícios e procedimentos, sem implicar na divisão dos resultados obtidos. As seguintes características são sugeridas: "ser simples; ser veloz no seu desenvolvimento; estar estruturado para atender grupos de empresas de segmentos similares ou correlatos; permitir subprodutos em cada uma das etapas do processo" (MORAIS, 1999, p.35). Além das características, é proposto, também, que no momento de modelagem do SIE, seja contemplada a seguinte estrutura básica: necessidade de informação harmonizada; SIE como processo coletivo; ganhos de competitividade; subsídio para a tomada de decisão.

Após a implantação do SIE, os principais benefícios que se espera alcançar são: minimização dos riscos nos processos de tomada de decisão; incorporação da postura estratégica e da visão prospectiva; melhor conhecimento da posição competitiva das empresas; identificação de alianças estratégicas e antecipação dos sinais de mudanças do ambiente empresarial. Assim, o SIE deverá produzir para a pequena empresa um mapa de informação sobre o ambiente externo e interno, "a partir de métodos práticos e adequados às especificidades da organização de tal porte, que atendam duas características imprescindíveis: velocidade de resposta e custo" (MORAIS, 1999, p.38).

\subsubsection{Proposta apresentada por DALFOVO e RODRIGUES (1998)}

A proposta dos autores é fruto de pesquisa realizada nas pequenas e médias empresas (PMEs) do setor têxtil de Blumenau, Santa Catarina.

Em visita às empresas foram observados problemas elementares de coleta, processamento e oferta de informações pelos sistemas informatizados. Os sistemas existentes nas empresas produziam relatórios de formatação complicada, eram pobres 
em informações e desestruturados (sem sumarizações e totalizações), demonstrando uma desatenção com a arquitetura dos sistemas e influenciando negativamente a qualidade das decisões. Na opinião dos autores, "a utilização adequada de informações, obtidas através de um sistema de informação bem estruturado, facilita ao executivo a tomada de decisão e o posicionamento estratégico da empresa" (DALFOVO e RODRIGUES, 1998, p.45).

Para solucionar tal problema foi proposto um sistema de informação estratégica para tomada de decisão nas PMEs, a partir do entendimento das empresas do que é um sistema de informação e uma decisão estratégica; quais delas utilizam sistema de informações e como foi estruturado e quais as principais informações necessárias ao desenho do SIE.

Deve ser considerado, também, que a implantação da nova tecnologia nas empresas iria afetar aspectos estruturais, processuais, comportamentais e de desempenho organizacional. Dessa forma, a visão e a tomada de decisão estratégica só será possível a partir da integração desses elementos. Conseqüentemente, "faz-se necessário desenhar um modelo que contenha tais elementos e aponte suas relações de peso" (DALFOVO e RODRIGUES, 1998, p.45).

O primeiro passo na determinação do modelo é a identificação do cenário com as respectivas demandas por informações das empresas. Para isso foram coletados os seguintes dados:

- A existência de sistemas de informação (46\% das empresas não possuíam sistema de informação - formal ou informal);

- Dados do ambiente externo e interno (60\% das empresas não coletavam dados dos concorrentes e $45 \%$ sobre os consumidores; internamente, $50 \%$ das informações coletadas são da área administrativa/financeira);

- Existência de informação dispersa internamente nas empresas (apenas em 23\% das empresas a informação circulava organizadamente);

- Recebimento de informações estratégicas em tempo hábil (apenas 15\% dos executivos recebiam informações no tempo desejado);

- Confiabilidade das informações estratégicas que circulavam internamente nas empresas (41\% dos respondentes indicaram receber informações confiáveis);

- Corporatividade e integração das informações estratégicas (apenas 23\% dos respondentes afirmaram que as informações são corporativas). 
Ficou constatado através dos dados coletados que os sistemas de informação não estavam sendo adequadamente utilizados para tomada de decisão estratégica. Existia uma forte resistência ao uso do computador.

Dessa forma, foi proposto inicialmente pelos autores um programa de sensibilização e treinamento acerca do uso de microcomputadores e sistemas de informações, para acabar com a resistência ao uso da tecnologia. E o Modelo de Sistema de Informação deve ter uma arquitetura corporativa com as seguintes características básicas:

- Manuseio simplificado - apresentar informações em formato de gráficos e figuras;

- Baixa complexidade estrutural - nível de complexidade da estrutura do sistema;

- Alta flexibilidade - deve atender às características de organização estrutural das PMEs;

- Arquitetura conceitual "down-up" - atender as características do negócio têxtil;

- Alta versatilidade e funcionalidade - capacidade de integrar e processar informações internas e externas.

Para o atendimento das características acima, a arquitetura do sistema deve conter dois grandes blocos: dados operacionais internos e informações externas. "Por fim, é preciso um monitoramento constante dos rumos das estratégias, da competitividade e das tecnologias da empresa" (DALFOVO e RODRIGUES, 1998, p.56). 


\section{TRABALHO DE CAMPO}

\subsection{Caracterização do setor pesquisado}

\subsubsection{Operações de serviços}

O setor de serviços está em ascensão em todo mundo. No setor de negócios, a prestação de serviços, abrange pessoas que trabalham em empresas de serviços (hotéis, bancos etc) e que prestam serviços dentro das indústrias (psicólogos, advogados etc).

Diferente da gestão da manufatura, os serviços apresentam natureza e características peculiares (figura 17), fazendo com que a gestão de suas operações seja distinta da tarefa de produzir bens (GIANESI e CORRÊA, 1996).

Serviço é "toda atividade ou benefício, essencialmente intangível, que uma parte pode oferecer à outra e que não resulte na posse de algum bem". Os serviços são, via de regra, intangíveis, inseparáveis, variáveis e perecíveis (KOTLER e ARMSTRONG, 1998, p.455).

\begin{tabular}{|l|l|}
\hline \multicolumn{1}{|c|}{ Características } & \multicolumn{1}{c|}{ Conceito } \\
\hline Intangibilidade & $\begin{array}{l}\text { Os serviços não podem ser vistos, provados, sentidos, ouvidos ou } \\
\text { cheirados antes da compra }\end{array}$ \\
\hline Inseparabilidade & Os serviços são inseparáveis de seus fornecedores \\
\hline Variabilidade & $\begin{array}{l}\text { A qualidade do serviço depende de quem os proporciona e quando, onde e } \\
\text { como são proporcionados }\end{array}$ \\
\hline Perecibilidade & Os serviços não podem ser estocados para venda ou uso futuro \\
\hline
\end{tabular}

\section{Figura 17 - Quatro características que distinguem os serviços dos bens}

Fonte: adaptado de Kotler \& Armstrong(1998, p.456)

- Intangibilidade - "os serviços não têm as características tangíveis que atraem os sentidos de visão, audição, sabor e tato dos consumidores”(BOONE e KURTZ, 1998, p.299). Os hóspedes de um hotel têm apenas a promessa de um bom descanso, por exemplo. Segundo Kotler (1998, p.414), "para reduzir a incerteza, os 
compradores procurarão sinais de evidência da qualidade do serviço", através da observação de lugares, pessoas, equipamentos, materiais de comunicação e preço.

- Inseparabilidade - "os serviços são inseparáveis daqueles que os fornecem, sejam pessoas ou máquinas" (KOTLER e ARMSTRONG, 1998, p.456). “As percepções do cliente relativas ao prestador de serviço tornam-se as percepções do próprio serviço"(BOONE e KURTZ, 1998, p.300).

- Variabilidade - “os serviços são altamente variáveis. Sua qualidade depende de quem os proporciona e de quando, onde e como são proporcionados" (KOTLER e ARMSTRONG, 1998, p.456). Kotler (1998) apresenta três sugestões para o controle da qualidade: investimento em seleção e treinamento de pessoal; padronização do processo de prestação de serviço por toda a organização; monitoramento da satisfação do consumidor, através de sistemas de sugestões e reclamações.

- Perecibilidade - os serviços são perecíveis, não podem ser estocados (KOTLER,1998). No caso da demanda ser instável as empresas enfrentam situações difíceis para o ajuste entre a oferta e a procura. Algumas estratégias podem ser desenvolvidas na busca do equilíbrio entre a demanda e a oferta. A função de produção ou operações ganha importância no setor de serviços pelas próprias características da prestação do serviço. Durante o fornecimento do serviço o produtor está interagindo diretamente com o consumidor, sendo importante para ele, não só o resultado da prestação do serviço, mas a satisfação durante todo o processo.

\subsubsection{Hotelaria}

O mundo da hotelaria é variado e trabalhoso. A hospedaria tem por missão responder carências - aconchego ambiental, trato pessoal, alimentação, conforto físico, higiene etc - com excelência (YÁZIGI, 2000). Envolve o tempo todo o relacionamento entre cliente e fornecedor.

Fora do ambiente familiar de sua casa, a vida do turista depende da funcionalidade, tanto em coisas banais como em serviços especiais: ser chamado na hora certa; deixar e receber recados; contar com serviços impecáveis de higiene, arrumação, alimentação, lavanderia; ter a disposição todos os equipamentos funcionando bem (televisão, ar-condicionado, abajures etc). A excelência está em tudo (YÁZIGI, 2000). Para o autor é um grande equívoco pensar que a pousada do rico tem 
de ser boa e a do caminhoneiro pode ser ruim. O detalhe fará a diferença em ambos os casos, tanto para as boas recordações como para as péssimas.

É preciso decidir em qual mercado se pretende trabalhar, pois tanto a arquitetura e a decoração, quanto o tipo de prestação de serviços têm de ser devidamente adaptados. Trabalhar com gente muito rica, pessoas da terceira idade, casais em lua-de-mel, crianças, adolescentes ou empregados da indústria e do comércio, com certeza o padrão que deve ser oferecido é diferente para cada um desses segmentos.

Os empreendimentos hoteleiros podem ser classificados por: categorias dos meios de hospedagem, produto, mercado, capital social, formas de administração e tamanho do empreendimento.

A classificação que será utilizada na pesquisa será a (figura 18) do número de unidades habitacionais.

\begin{tabular}{|l|l|l|l|}
\hline & $\begin{array}{l}\text { CNTUR } \\
\text { RESOLUÇÃO 1023 } \\
\text { UFIR/MÊS }\end{array}$ & $\begin{array}{l}\text { MINISTÉRIO DA } \\
\text { FAZENDA } \\
\text { UFIR/ANO }\end{array}$ & $\begin{array}{l}\text { NÚMERO } \\
\text { DE } \\
\text { APARTAMENTOS }\end{array}$ \\
\hline PEQUENO & $<10.000$ & $\begin{array}{l}\text { Microempresa } \\
<96.000\end{array}$ & 1 a 40 \\
\hline MÉDIO & 10.000 a 25.000 & $\begin{array}{l}\text { Lucro presumido } \\
\text { De } 96.000 \text { a } 9.600 .000\end{array}$ & 41 a 200 \\
\hline GRANDE & $>25.000$ & $\begin{array}{l}\text { Lucro real } \\
>9.600 .000\end{array}$ & $>200$ \\
\hline
\end{tabular}

Figura 18 - Tamanho do hotel

Fonte: DUARTE, 1996, p.36.

Qualquer que seja a categoria do hotel ou mesmo o número de unidades habitacionais, a estrutura organizacional pode ser reduzida a quatro processos principais (DUARTE, 1996):

- Comercial - atividades de relações públicas, promoções, vendas e reservas de hotel. Os principais indicadores de vendas são: a ocupação do hotel, a diária média e o market share;

- Hospedagem - atividades ligadas à recepção do hotel, telefonia, governança e, muitas vezes, as de lazer ou eventos em hotel;

- Alimentos \& bebidas - é dividida em três processos: produção, serviço e eventos;

- Administrativo - coordenar administrativamente e financeiramente o hotel, incluindo as áreas de recursos humanos, manutenção e segurança. A área de 
administração abrange as atividades de compras, recebimento e estocagem de mercadorias, controle de custos e controle de comidas e bebidas. Na área de finanças as principais tarefas estão ligadas à área contábil.

Além dos processos organizacionais, existe a gerência geral que irá coordenar todos esses processos para melhorar sempre a qualidade e a produtividade e aumentar a rentabilidade do negócio. Duas das principais funções da gerência geral são a definição dos níveis adequados para a ocupação do hotel e do valor da diária média. Nos pequenos hotéis, a função da gerência pode abranger os processos comercial e administrativo e, normalmente, é exercida pelo proprietário (DUARTE, 1996).

Para Yázigi (2000), os processos organizacionais de um hotel de pequeno porte abrangem as seguintes atribuições: a de administração, a de alimentação e a de hospedagem. O autor faz algumas recomendações úteis à gestão do negócio:

- Dedicação total dos proprietários ao empreendimento, em função da quantidade mínima de funcionários contratados, devido à limitação dos recursos financeiros. Um hotel de pequeno porte é uma empresa de poucos empregados e muito trabalho.

- Oferecer atendimento personalizado, apresentando um "estilo diferente de se hospedar, mais familiar, econômico, menos variado em serviços, mas não necessariamente de qualidade inferior", para que seja possível competir com as grandes redes hoteleiras (YÁZIGI, 2000, p.9).

- Não desprezar a vizinhança onde está localizado, reconhecendo a importância do entorno municipal. "Pouco adianta criar pacotes turísticos, se turismo e misériaviolência são incompatíveis; se as tarifas nacionais de avião continuam relativamente altas; se os preços em geral são insustentáveis; se não há base profissional para o turismo" (YÁZIGI, 2000, p.57);

- Ser criterioso na escolha dos recursos humanos. A dificuldade começa com a gerência, a alma da hospedaria. O lucro depende da genialidade da gerência. $\mathrm{O}$ gerente precisa entender de tudo: limpeza, alimentação, manutenção, trato com os clientes etc, precisa ser polivalente para alcançar os objetivos.

\subsubsection{Setor turístico e hoteleiro da região de Brotas - SP}

Brotas/SP e região estão se destacando no Estado de São Paulo pela sua vocação para o turismo. Composta pelas cidades de: Águas de São Pedro, Analândia, Brotas, Ipeúna, Itirapina, São Pedro, Torrinha, entre outras, esta região com inúmeros atrativos 
turísticos naturais, desenvolve o turismo de aventura e o turismo ecológico entre outras modalidades. A classificação dos municípios realizada pelo Ministério do Esporte e Turismo (figura 19) evidencia o potencial da região para o desenvolvimento das atividades ligadas ao setor de turismo.

\begin{tabular}{|l|l|}
\hline \multicolumn{1}{|c|}{ CLASSIFICAÇão } & \multicolumn{1}{c|}{ MUNICÍPIO } \\
\hline $\begin{array}{l}\text { Águas de São Pedro, São Pedro e } \\
\text { Analândia }\end{array}$ & Estâncias turísticas \\
\hline Brotas e Itirapina & Municípios turísticos \\
\hline Ipeúna & Município com potencial turístico \\
\hline Torrinha & Município em fase de desenvolvimento \\
\hline
\end{tabular}

Figura 19 - Classificação dos municípios pelo Ministério do Esporte e Turismo Fonte: http://www.turismopaulista.sp.gov.br/index3.asp

Nos diagnósticos municipais, elaborados pela Unidade de Desenvolvimento Local do Sebrae-SP (2000b e 2001), duas cidades da região são analisadas: Brotas e Águas de São Pedro.

A cidade de Brotas é considerada um pólo turístico que atrai turistas de várias partes do Brasil que buscam aventura e sossego em hotéis e pousadas da cidade. $\mathrm{O}$ município tem recebido mais de 110 mil turistas por ano, o que fez aumentar o número de hotéis e restaurantes em mais de $100 \%$.

Por outro lado, Águas de São Pedro, considerada a cidade-saúde, foi projetada com o propósito específico de ser um local de cura e lazer, com garantias da qualidade de vida desfrutadas por seus habitantes e visitantes. "Tem sua economia voltada exclusivamente para o turismo (não possui atividades agrícolas ou pecuárias expressivas)" (SEBRAE-SP, 2001, p.33).

No diagnóstico municipal, ficou constatado, também, que Águas de São Pedro e outras estâncias turísticas, passaram a sofrer pesada concorrência de entrantes nacionais e internacionais (resorts ou complexos balneário-hoteleiros) na luta pelos clientes regionais e estaduais.

A pesquisa desenvolvida no setor hoteleiro destes municípios e realizada pelo GEOPE-SEP-EESC-USP foi dividida em duas partes: a primeira, compreendendo o mapeamento dos hotéis da região por meio da aplicação de dois questionários (Apêndice A e B) por um aluno de iniciação científica e a segunda, compreendendo a 
investigação sobre o processo de gestão estratégica dessas empresas, realizada por quatro alunos de mestrado.

O aluno de iniciação científica realizou um mapeamento das empresas hoteleiras e chegou a um total de cem empresas na região. Desse total foram desconsiderados quatro hotéis de porte médio e não foi concretizado o contato (após várias tentativas) em dezessete empresas por causa de problemas com os dados disponíveis; sendo que duas empresas haviam encerrado suas atividades. Assim, o convite para participar da pesquisa foi feito a setenta e sete empresas hoteleiras de pequeno porte. Após o convite, quarenta e nove aceitaram participar, oito não aceitaram e vinte não responderam ao convite. O pesquisador destaca a adesão extremamente significativa das empresas, visto que, 64\% das empresas contatadas aceitaram participar da pesquisa (ANDRADE, 2003).

Nas empresas que aceitaram participar da pesquisa, foram aplicados os questionários de Caracterização da Empresa (Questionário 1 - Apêndice A) e o de temas específicos (Questionário 2 - Apêndice B). Das quarenta e nove empresas que receberam o questionário, trinta e nove responderam o questionário 1 e vinte e sete responderam o questionário 2 , obtendo uma fração significativa para análise.

A distribuição, por cidade, das empresas contatadas e das que responderam os questionários é apresentada na tabela 4.

Tabela 4 - Distribuição das empresas por cidade

\begin{tabular}{|l|c|c|c|}
\hline \multicolumn{1}{|c|}{ CIDADE } & $\begin{array}{c}\text { EMPRESAS } \\
\text { CONTATADAS }\end{array}$ & $\begin{array}{c}\text { EMPRESAS } \\
\text { ANALISADAS (Q1) }\end{array}$ & $\begin{array}{c}\text { EMPRESAS } \\
\text { ANALISADAS (Q2) }\end{array}$ \\
\hline Águas de São Pedro & 15 & 07 & 06 \\
\hline Analândia & 05 & 04 & 03 \\
\hline Brotas & 29 & 17 & -- \\
\hline Ipeúna & 02 & 01 & 02 \\
\hline Itirapina & 02 & 02 & 04 \\
\hline São Pedro & 23 & 07 & -- \\
\hline Torrinha & 01 & 01 & $\mathbf{2 7}$ \\
\hline TOTAL & $\mathbf{7 7}$ & $\mathbf{3 9}$ & \\
\hline
\end{tabular}

Fonte: ANDRADE (2003, p.65) 


\subsubsection{Caracterização das pequenas empresas hoteleiras da Região de Brotas}

Nos resultados da pesquisa realizada por Andrade (2003), foram observadas as seguintes características: do empreendimento, do dirigente, da gestão do empreendimento, do ambiente empresarial, do planejamento estratégico e da gestão da informação. Os empreendimentos possuem em média 10 anos de 'vida' e são administrados, predominantemente, por seus proprietários, onde empregam de 1 a 5 pessoas. Normalmente, possuem acomodações que vão de quartos do tipo simples até sofisticados chalés de madeira. Cerca de $80 \%$ dos hotéis e pousadas da região possuem menos de 20 unidades habitacionais e oferecem atrativos adicionais tais como área de lazer, passeios por trilhas ecológicas entre outros.

Os hotéis são administrados em sua grande maioria pelo proprietário. No entanto, observa-se que ao iniciar o negócio mais de $70 \%$ dos dirigentes dos empreendimentos hoteleiros estudados não tinham nenhuma experiência em hotelaria, mas foram motivados principalmente pela identificação de uma oportunidade de negócio. Em 54\% das empresas analisadas o dirigente possui a empresa como sua única fonte de renda, dedicando-se integralmente ao negócio. Verifica-se também um alto nível de escolaridade, mas são poucos os que possuem alguma especialização em hotelaria ou áreas afins.

Quanto à gestão dos hotéis, foram verificadas a predominância da experiência e a ausência de ferramentas administrativas formalizadas. Embora muitos não tenham experiência anterior em hotelaria, a maioria considerou a experiência em outras atividades empresariais como útil à gestão do empreendimento. Os dirigentes estão bastante envolvidos com os aspectos operacionais e administrativos, atendendo a objetivos imediatos ou de curto prazo, restando, portanto, pouco tempo para ações estratégicas (visando atender objetivos de longo prazo) e para construção de uma visão futura do empreendimento.

Outro aspecto importante é que na maioria dos casos a gestão do empreendimento é voltada principalmente para a 'sobrevivência' do negócio e de objetivos associados às realizações pessoais e com pouca orientação para a busca de crescimento da empresa.

Andrade (2003) constatou também que os hotéis estudados terceirizam poucos serviços, mesmo possuindo uma estrutura simples. Os dirigentes também expressaram, 
de maneira unânime, que consideram importante a participação dos funcionários na identificação e na solução dos problemas da empresa.

$\mathrm{O}$ ambiente empresarial em que os hotéis atuam é bastante competitivo devido à grande oferta de serviços disponíveis. Entretanto, segundo os dirigentes destes empreendimentos, o clima de concorrência não é extremamente acirrado, pois atende a 'bolsos e gostos' distintos, além do que, nos períodos de alta temporada a demanda é suficiente para que todos tenham um nível de ocupação satisfatório. De forma geral, os clientes buscam atividades de lazer cultural e de aventura proporcionadas pelas características da região. Especificamente na cidade de Águas de São Pedro, as atividades relacionadas à saúde são bastante procuradas em decorrência dos banhos medicinais.

Os fatores do ambiente empresarial afetam esses empreendimentos assim como os demais setores da economia, entretanto, as ações dos dirigentes não são muito sistemáticas no sentido de acompanhar o desenvolvimento desses fatores e se anteciparem às mudanças.

O poder público local, na medida do possível, apóia o desenvolvimento do turismo, no entanto, medidas mais eficazes poderiam ser tomadas. Em algumas cidades, como Brotas e Analândia, os dirigentes se reúnem, visando unir esforços e discutir os problemas locais, de modo a obterem soluções conjuntas para os problemas que possam atrapalhar o desenvolvimento do turismo e conseqüentemente de seus negócios.

Quando o tema é planejamento estratégico, é possível identificar uma preocupação com a definição dos caminhos a serem seguidos pela empresa e a forma como percorrê-los. No entanto, em apenas $44 \%$ destas empresas são realizadas reuniões para discutir o planejamento estratégico e poucas vezes os planos são escritos em um documento e divulgados na empresa. Percebe-se, também, nas respostas que a maior parte do tempo dos dirigentes é utilizada para solucionar problemas já existentes, na grande maioria simples, rotineiros e repetitivos. Os dirigentes destacam ainda que alguns dos problemas enfrentados atualmente pela empresa, poderiam ter sido evitados com o planejamento. Outro aspecto a destacar é que muito dos problemas possuem origem externa à empresa e não dependem apenas da ação individual do dirigente, como, por exemplo, pensar e agir para toda a região, divulgando seus atrativos naturais e atraindo maior número de clientes durante a semana. Andrade (2003) constatou que nos hotéis a formulação da estratégia ocorre de maneira bastante informal, onde os 
planos não são formalizados e as decisões são baseadas mais na experiência do empresário do que em processos sistematizados de planejamento estratégico.

Quanto à gestão da informação, a maioria dos dirigentes acompanha, com regularidade, as informações consideradas importantes para o negócio. As informações externas consideradas mais importantes são aquelas sobre os clientes, a economia, a ecologia, a cultura e sobre os fornecedores. Já em relação às informações internas, as mais importantes são relacionadas às atividades de hospedagem, de manutenção, de finanças e comercial. O monitoramento destas informações é realizado por meio de contatos com outros empresários da área, leituras (jornais em geral e imprensa especializada), contato com clientes (pesquisas de satisfação e conversas informais), acompanhamento dos acontecimentos da sociedade e internos à empresa, televisão, internet, funcionários, viagens, revistas e livros especializados do setor.

Segundo Andrade (2003), as dificuldades encontradas pelos empresários na busca de informações são: falta de tempo, de pessoal qualificado e de recursos financeiros; não obtenção de informações confiáveis nos veículos de comunicação disponíveis; falta de conhecimentos específicos do setor onde atua; falta de conhecimento sobre o local onde procurá-las e falhas internas de comunicação da informação.

\subsection{Caracterização da metodologia da pesquisa}

\subsubsection{Tipo da pesquisa}

Quanto às suas características, esta pesquisa pode ser classificada (SILVA e MENEZES, 2000; TRIVIÑOS, 1992):

- De acordo com a natureza, como aplicada: busca gerar conhecimentos para aplicação prática na resolução de problemas específicos;

- De acordo com a forma de abordagem do problema, como qualitativa: reconhece que existe uma relação dinâmica entre o mundo real e o sujeito. Não requer a utilização de técnicas estatísticas, sendo o ambiente natural a fonte direta para se coletar os dados;

- De acordo com os objetivos, como exploratória: têm o propósito de aumentar o conhecimento sobre o problema com o objetivo de torná-lo claro ou para construir hipóteses (SILVA e MENEZES, 2000). 
- De acordo com os procedimentos técnicos, como um estudo comparativo de casos: busca-se estudar profundamente mais de uma empresa, fazendo comparações entre as empresas estudadas, pois "o enfoque comparativo enriquece a pesquisa qualitativa" (TRIVIÑOS, 1992, p.136).

$\mathrm{O}$ estudo será realizado na Região de Brotas/SP, em quatro hotéis de pequeno porte e em um hotel de médio porte, este último atendendo sugestão da Assessoria Científica da FAPESP.

A seleção das empresas será realizada também, a partir dos questionários (apêndice A e B) aplicados pelo aluno de iniciação científica José Henrique de Andrade (bolsista FAPESP). Caracteriza-se como uma amostra não-probabilística do tipo intencional, pois a escolha do pesquisador será baseada na disposição do dirigente em participar da pesquisa e de características de gestão da informação e administração estratégica existentes nas empresas e pré-constatadas por Andrade (2003).

\subsubsection{Questões da pesquisa}

Segundo TRIVIÑOS (1992, p.107), "a questão de pesquisa representa o que o investigador deseja esclarecer", sendo formulada a partir do problema e dos objetivos da pesquisa.

Desta forma, as questões da pesquisa são as seguintes:

- Qual o processo de análise estratégica da empresa (interna)?

- Quais os tipos e fontes de informações internas, úteis à gestão estratégia?

- Quais as atividades do gerenciamento estratégico da informação?

- Quais são as especificidades de gestão da pequena empresa e como elas influenciam as atividades de gerenciamento da informação para fins estratégicos?

\subsubsection{Variáveis da pesquisa}

De acordo com o objetivo proposto, são variáveis da pesquisa:

a) Análise estratégica da empresa (interna): é o processo de análise dos recursos, capacidades e resultados atuais da empresa para identificação de suas forças e fraquezas, conforme revisão registrada no capítulo 2, seção 2.1;

b) Informação estratégica (interna): é o produto da interpretação dos dados referentes aos recursos e capacidades organizacionais atuais e do acompanhamento do 
desempenho da estratégia implementada, que permite ao executivo identificar pontos fortes e fracos úteis à elaboração e implementação da estratégia e ao monitoramento dos resultados da execução da estratégia através dos indicadores de desempenho, conforme revisão registrada no capítulo 2, seção 2.2.4;

b1) Fontes: corresponde ao local onde está localizada a informação. O local da sua procedência, conforme descrito nas figuras 23 e 24 do capítulo 4 .

b2) Tipos: corresponde a natureza da informação, de acordo com finalidade a que ela se destina, conforme descrito nas figuras 21, 23 e 24 do capítulo 4 .

b3) Gestão da informação: Compreende as etapas de identificação, coleta, tratamento, armazenamento, distribuição e utilização das informações disponíveis internamente na empresa nas atividades de planejamento, implementação e avaliação da estratégia, visando a obtenção de vantagem competitiva, conforme descrito na figura 21 do capítulo 4.

c) Especificidades da pequena empresa: são as características típicas de gestão que influenciam no gerenciamento das informações para fins estratégicos, conforme figuras $12,13,14,15$ e 16 do capítulo 3.

\subsubsection{Técnica de coleta e análise dos dados}

O processo de coleta de dados será realizado por meio de observação da realidade e entrevista pessoal com o proprietário-gerente dos hotéis selecionados, com base em um roteiro pré-estabelecido. A observação consiste no registro de comportamentos, fatos e ações relacionadas ao objetivo da pesquisa (MATTAR, 1996).

Nesta pesquisa a observação é classificada (MATTAR, 1996):

- Quanto ao grau de estruturação: não estruturada - apenas os assuntos a serem observados estão listados;

- Quanto ao grau de disfarce: não disfarçada - permite total transparência ao pesquisado;

- Quanto aos instrumentos utilizados: observação humana e por instrumentos;

- Quanto ao ambiente: natural - observar o fato onde ele ocorre;

- Quanto ao objeto observado: observação direta - no momento da ocorrência.

A entrevista consiste no contato pessoal entre entrevistador e entrevistado, para obtenção dos dados (MATTAR, 1996). A entrevista será semi-estruturada. Valorizando 
o investigador e oferecendo todas as possibilidades para que o entrevistado alcance a liberdade e espontaneidade necessárias para o fornecimento das informações (TRIVIÑOS, 1992). Será realizada em conjunto com outros três mestrandos, cada um investigando um tema e utilizando um roteiro específico para entrevista, relacionado à gestão estratégica das empresas hoteleiras de pequeno porte.

Ao final desta fase será realizada a tabulação dos dados coletados, seguida da interpretação, que poderá indicar a necessidade de obtenção de mais informações, demandando outras entrevistas.

O roteiro de entrevista foi testado em alguns hotéis da cidade de São Carlos, a fim de verificar sua adequação aos propósitos da pesquisa. Após o pré-teste foram realizadas algumas modificações, constituindo um novo roteiro de entrevistas (Apêndice C).

A análise dos dados significa trabalhar o material obtido durante a pesquisa (LUDKE e ANDRÉ, 1986), isto é, os dados conseguidos por meio da observação pessoal do pesquisador e durante as entrevistas com os dirigentes e funcionários. As autoras afirmam que a análise implica em duas tarefas. Na primeira tarefa o material deve ser organizado e dividido em partes que possibilitem a identificação de tendências e padrões relevantes. Corresponde à construção de um conjunto de categorias descritivas, ou seja, a identificação das variáveis de pesquisa a partir do objetivo e da revisão bibliográfica.

A segunda tarefa corresponde na reavaliação das tendências e padrões na busca de relações e inferências. "É preciso que o pesquisador vá além, ultrapasse a mera descrição, buscando realmente acrescentar algo à discussão já existente sobre o assunto focalizado" (LUDKE e ANDRÉ, 1986, p.49), ou seja, o pesquisador precisa ir além da apresentação organizada dos dados. É necessário estabelecer relações entre as variáveis de pesquisa e inferir resultados dessas relações.

\subsection{Fundamento conceitual}

Esta seção tem o propósito de realizar uma síntese dos conceitos revisados nos capítulos 2 e 3, para a construção de um esquema conceitual geral que será utilizado como guia para o desenvolvimento do trabalho de campo.

O esquema geral está apresentado na figura 20: o bloco A trata do processo de análise interna da empresa e da gestão estratégica da informação; o bloco B trata das 
especificidades da pequena empresa; e o bloco $\mathrm{C}$ do gerenciamento estratégico da informação na pequena empresa, objeto de investigação deste trabalho.

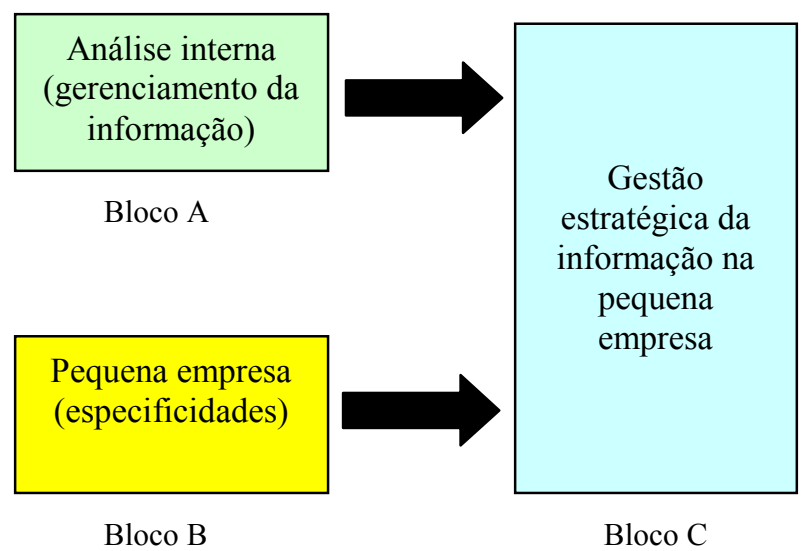

Figura 20 - Esquema geral de orientação do trabalho de campo Fonte: elaboração própria

a) Análise interna (Gerenciamento da Informação) (Bloco A da figura 20)

No capítulo 2, na seção 2.1, foram apresentadas as etapas do processo de administração estratégica (figura 3, p.20), sendo priorizado o processo de análise dos aspectos internos, visando descobrir as informações internas de natureza estratégica que podem ser utilizadas na identificação das vantagens e desvantagens competitivas da empresa. A seção 2.2 do mesmo capítulo descreveu as metodologias para o gerenciamento da informação.

b) Especificidades da pequena empresa (Bloco B da figura 20)

O capítulo 3 descreveu as especificidades da pequena empresa (ambientais, estratégicas, estruturais, tecnológicas e comportamentais do dirigente) que podem influenciar o gerenciamento estratégico da informação.

C) Gerenciamento estratégico da informação na pequena empresa (Bloco $C$ da figura 20)

A síntese teórica do gerenciamento da informação de natureza estratégica, considerando as especificidades da pequena empresa, está registrada no roteiro de campo e será utilizado na orientação da coleta de dados no trabalho de campo. Este roteiro é provisório, pois após a coleta e análise dos dados o pesquisador fará a proposição de um roteiro de gerenciamento da informação. 


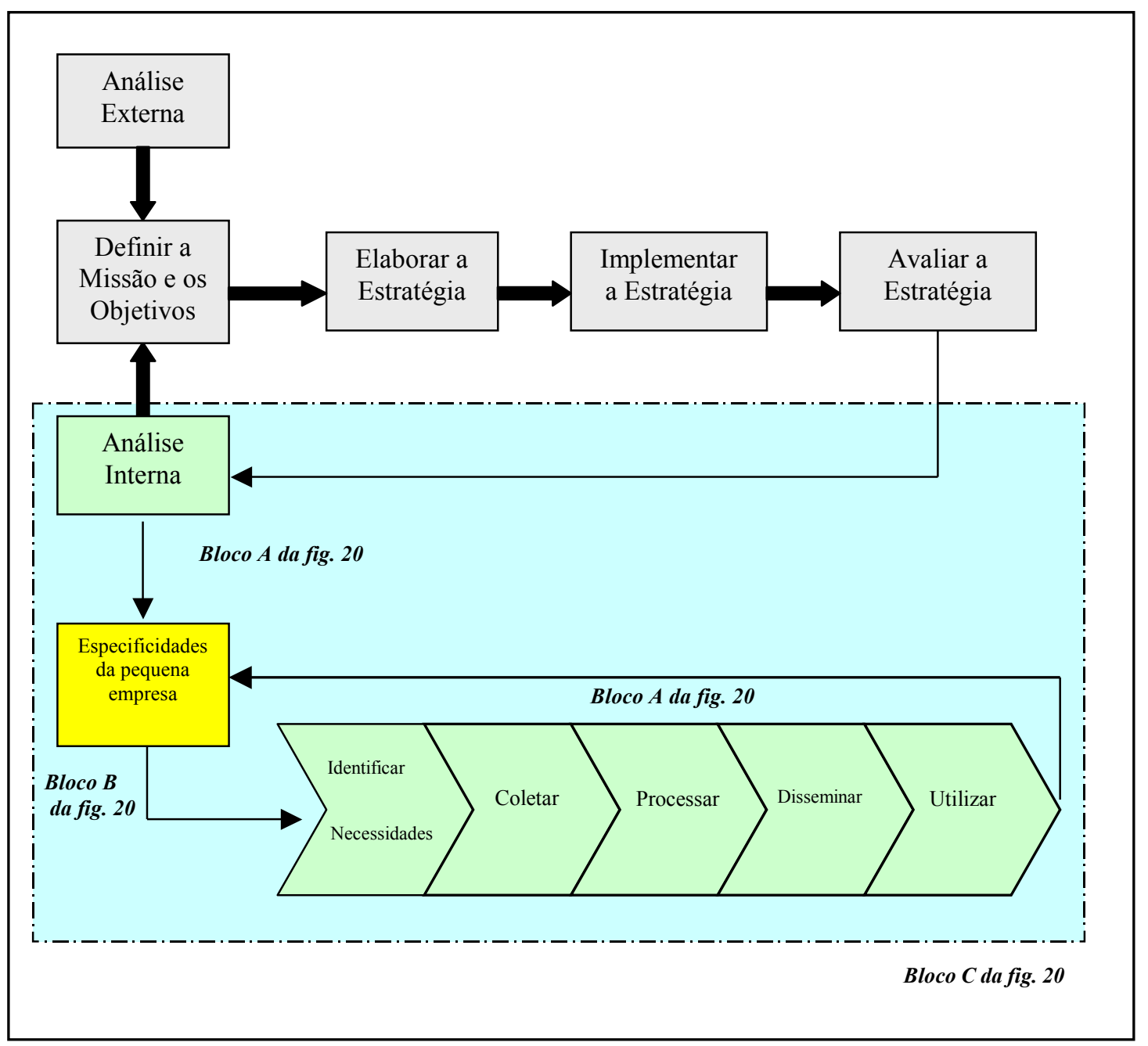

Figura 21 - Detalhamento do Esquema Geral

Fonte: elaboração própria

\section{ROTEIRO DE CAMPO}

$\mathrm{O}$ roteiro aplicado no trabalho de campo consiste de seis etapas para o gerenciamento estratégico da informação (figura 22).

Para obter os benefícios propiciados pelo gerenciamento estratégico da informação, é preciso que o dirigente se conscientize da necessidade de administrar a empresa através da análise sistemática das informações disponíveis internamente na empresa. Assim, a primeira etapa para o gerenciamento da informação na pequena empresa, é o entendimento por parte do dirigente de que a informação estratégica ajudao a refletir sobre as capacidades e dificuldades da sua empresa no momento presente e acompanhar o desempenho das áreas críticas para o sucesso do empreendimento. O que está sendo enfatizado é o gerenciamento da informação para o processo estratégico. 
Outros aspectos do gerenciamento da informação, como, por exemplo, das operações da empresa, não é preocupação deste trabalho.

\begin{tabular}{|c|c|}
\hline ETAPAS & ATIVIDADES \\
\hline $\mathbf{1}^{\mathrm{a}}$ & - $\quad$ Conscientização do dirigente \\
\hline $2^{a}$ & $\begin{array}{l}\text { Identificação das necessidades de informação } \\
\text { - Informações sobre os recursos e capacidades } \\
\text { - Informações de resultados }\end{array}$ \\
\hline $3^{\mathbf{a}}$ & $\begin{array}{l}\text { - } \quad \text { Coleta de dados } \\
\text { - Seleção de fontes e dados } \\
\text { - Aquisição de dados }\end{array}$ \\
\hline $4^{a}$ & $\begin{array}{l}\text { Processamento de dados } \\
\text { - Tratamento dos dados } \\
\text { - Armazenamento dos dados }\end{array}$ \\
\hline $5^{\mathbf{a}}$ & $\begin{array}{l}\text { - Disseminação de informações } \\
\text { - Definição da forma de apresentação das informações } \\
\text { - Escolha do canal de transmissão }\end{array}$ \\
\hline $6^{\mathbf{a}}$ & $\begin{array}{l}\text { - Utilização das informações } \\
\text { - Recuperação e análise das informações } \\
\text { - Incorporação ao processo decisório }\end{array}$ \\
\hline
\end{tabular}

Figura 22 - Etapas do processo de gerenciamento estratégico da informação Fonte: elaboração própria

A segunda etapa do processo de gestão da informação é a identificação das necessidades de informação dos dirigentes, isto é, dos tipos e fontes de informações. Os dirigentes necessitam de informações sobre os recursos e capacidades de marketing (comercial), de alimentos e bebidas, de hospedagem e de administração (figura 23), e informações de resultados (figura 24), monitoradas através dos indicadores de desempenho da empresa.

A terceira etapa consiste na coleta dos dados, isto é, na seleção de fontes e dados, e aquisição de dados. A coleta pode ser feita por meio da observação e análise de relatórios de vendas, financeiros e do acompanhamento dos índices que refletem o desempenho; de entrevistas ou reuniões com funcionários, ou através da recuperação de informações arquivadas manualmente ou eletronicamente.

Ao definir a forma de coletar (manual ou eletrônica), não se pode esquecer que informações têm valor, mas têm custo também. E que a pequena empresa dispõe de poucos recursos para desperdiçar com a coleta de informações irrelevantes. Por isso, o diagnóstico das reais necessidades de informação dos usuários é fundamental. Outras especificidades que podem influenciar nesse diagnóstico são as especificidades relacionadas às percepções e competências dos dirigentes. 


\begin{tabular}{|c|c|}
\hline TIPOS DE INFORMAÇÃO & FONTES \\
\hline $\begin{array}{l}\text { Do processo de Marketing (comercial) - informações relativas ao } \\
\text { produto, preço, forma de distribuição, promoção, política comercial, } \\
\text { força de vendas, organização do setor. } \\
\text { - Do processo de Hospedagem - informações sobre custos, qualidade, } \\
\text { nível de estoque, instalações, tecnologia de operação, equipamentos. } \\
\text { Do processo de Alimentos \& Bebidas - informações sobre custos, } \\
\text { qualidade, nível de estoque, instalações, tecnologia de operação, } \\
\text { equipamentos. } \\
\text { Do processo Administrativo - informações sobre a área financeira - } \\
\text { análise dos índices financeiros, a organização do sistema de controle } \\
\text { financeiro e contábil, a capacidade dos relatórios e demonstrativos de } \\
\text { informar o desempenho da empresa etc; informações sobre os } \\
\text { recursos humanos da empresa - experiência e sensibilidade dos } \\
\text { executivos, habilidades e conhecimentos dos gerentes e funcionários, } \\
\text { aspirações, valores e crenças de gerentes e funcionários etc; } \\
\text { informações sobre os aspectos que abrangem toda a empresa - } \\
\text { estrutura, cultura e clima organizacional, políticas, sistema de } \\
\text { informações etc. }\end{array}$ & $\begin{array}{ll}\text { - } & \text { Banco de } \\
\text { - } & \text { Rados } \\
\text { - } & \text { Observação } \\
\text { informal } \\
\text { - Entrevistas } \\
\text { - } \text { Reuniões }\end{array}$ \\
\hline
\end{tabular}

Figura 23 - Informações sobre os recursos e capacidades organizacionais Fonte: elaboração própria

A quarta etapa corresponde ao processamento de dados e informações. $\mathrm{O}$ processamento é a organização dos dados de modo que seja facilmente recuperado pelo usuário. Esta etapa consiste no tratamento e armazenamento de dados e informações, podendo-se utilizar várias formas, desde os tradicionais registros em papéis até às diferentes mídias (arquivos digitais).

O tratamento deve ser feito de acordo com o objetivo do usuário, para que ele consiga recuperar o dado ou a informação. O tratamento dos dados envolve: registro, apreciação do conteúdo, elaboração de sínteses, condensação das informações relevantes e indexação (MORAIS, 1999). 


\begin{tabular}{|c|c|c|}
\hline ATIVIDADES & INDICADOR DE DESEMPENHO & FONTES \\
\hline - Marketing & $\begin{array}{l}\text { - Ocupação do hotel } \\
\text { - } \text { Diária média } \\
\text { - Índice de reservas } \\
\text { - Índice de queixas dos clientes } \\
\text { - Serviços oferecidos aos clientes } \\
\text { - Vendas por empregado } \\
\text { - } \quad \text { Relacionamento com a clientela }\end{array}$ & \\
\hline $\begin{array}{l}\text { Hospedagem } \\
\text { Alimentos } \\
\text { Bebidas }\end{array}$ & $\begin{array}{l}\text { - } \quad \text { Relatórios de estoques de itens abaixo do ponto } \\
\text { - } \quad \text { melínimo } \\
\text { - } \quad \text { Quantidio de custos } \\
\text { - } \quad \text { Índice de perdas } \\
\text { - } \quad \text { Tempo total de produção } \\
\text { - } \quad \text { Número de novos métodos de produção adotados } \\
\text { - } \quad \text { Economia de tempo e de custos pelo emprego de } \\
\text { novos métodos e tecnologias }\end{array}$ & $\begin{array}{l}\text { - Banco de } \\
\text { dados } \\
\text { - Relatórios }\end{array}$ \\
\hline - Administrativo & $\begin{array}{l}\text { - Índice de utilização da força de trabalho } \\
\text { - } \text { Absenteísmo de empregados e taxa de } \\
\text { - } \text { rotatividade } \\
\text { - Número de reivindicações de empregados } \\
\text { - } \text { Horas trabalhadas pelos empregados além dos } \\
\text { - } \text { níveis estabelecidos } \\
\text { - } \text { Benefícios e incentivos ao trabalhador } \\
\text { - Lucro como porcentagem das vendas } \\
\text { - Vendas efetivas de produtos comparadas às } \\
\text { - } \text { vendas previstas } \\
\text { - Lucro por empregado } \\
\text { - Índices de dívida } \\
\text { - Instrumentos de controle gerencial } \\
\text { - Pesquisa de clima organizacional }\end{array}$ & \\
\hline
\end{tabular}

Figura 24 - Informações de resultados

Fonte: elaboração própria

Os dados arquivados de forma estruturada devem ser de fatos relativos ao negócio, refletindo as ações da empresa e as necessidades individuais do tomador de decisão. $\mathrm{O}$ armazenamento de dados e informações de forma desordenada e sem relação 
com o negócio, proporciona desperdício de recursos e impede que o objetivo do sistema seja alcançado - disponibilizar a informação correta, no formato desejado, à pessoa certa e no momento oportuno.

A quinta etapa do processo de gestão da informação é a disseminação (distribuição). Consiste na definição da forma de apresentar as informações e na escolha do canal que será utilizado para transmissão das informações. Corresponde, também, à criação de produtos e serviços de informações e divulgação. Até a etapa anterior foi definido o que o sistema deveria mostrar. Esta etapa nos diz como exibir e distribuir o que foi definido nas etapas anteriores.

A informação pode ser exibida através de relatórios (gráficos), tabelas, quadro de avisos etc, e distribuída por meio de: conversas, exposições, ofícios, telefonemas ou correio eletrônico. Devendo ser eliminado tudo o que não é essencial à gestão empresarial. A empresa pode utilizar sua própria rede de comunicação, simplificando o processo e economizando recursos.

A última etapa é a utilização pelos usuários das informações distribuídas. Os usuários recuperam e analisam as informações e incorporam-nas ao processo decisório ao realizar as atividades de planejamento, execução e controle da estratégia empresarial. Essas informações permitem uma radiografia da empresa, para que o dirigente possa identificar as forças e fraquezas da sua empresa e escolher o melhor caminho para condução do seu negócio.

Não se deve esquecer que todo processo tem que ser realimentado constantemente.

\subsection{Descrição das empresas estudadas}

Os hotéis participantes desta pesquisa são identificados como hotéis A, B, C, D e E. A descrição dos hotéis foi realizada com base nos dados coletados no questionário de caracterização do empreendimento (Apêndice A), nos sites disponíveis na internet e nas propagandas realizadas pelos hotéis .

\subsubsection{Hotel A}

O hotel A foi fundado em 1995 e está localizado em uma fazenda a $10 \mathrm{~km}$ do centro de Brotas/SP. Seu objetivo é desenvolver as atividades de lazer e ecoturismo em 
meio às belezas da natureza, valorizando o turismo sustentável ${ }^{21}$. Antes do hotel fazenda, até o início da década de noventa, a atividade econômica da fazenda estava ligada apenas à agropecuária, quando surgiu a idéia de trabalhar com o turismo ecológico, para aproveitar os recursos naturais disponíveis na fazenda.

O hotel fazenda oferece bosque, minicampo, salão de jogos, piscina, quadra de tênis, represa para pesca, passeio a cavalo, visita a corredeiras do Rio Tamanduá, tiroleza, monitores para hóspedes, salão para convenções e eventos, restaurante (comida típica) e hospedagem em seus trinta apartamentos (unidades habitacionais) com tv, ar condicionado, frigobar, telefone e varanda com rede.

Os cinco proprietários do hotel têm formação acadêmica nas áreas de Nutrição, Assistência Social, Direito e Zootecnia. Atualmente o hotel é a única fonte de renda para quatro dos proprietários. Uma das proprietárias também trabalha como Assistente Social na cidade.

O hotel possui 16 funcionários que trabalham no nível operacional. No nível administrativo o hotel tem três unidades de trabalho (figura 25) sendo gerenciadas por quatro proprietários, cada um ocupando determinada função.

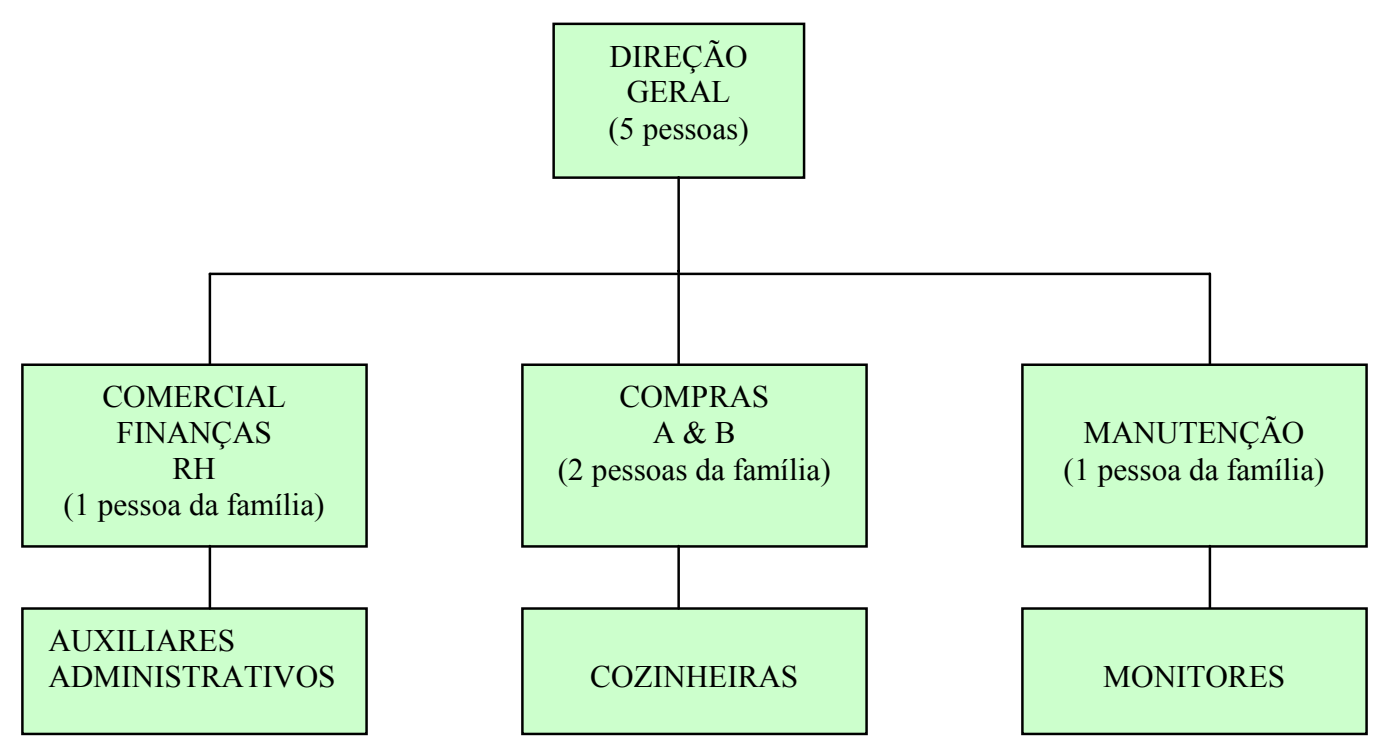

Figura 25 - Organograma do hotel A

Fonte: elaboração própria

21 “Maximização e otimização da distribuição dos benefícios do desenvolvimento econômico baseado no estabelecimento e na consolidação das condições de segurança sob as quais serão oferecidos os serviços turísticos, para que os recursos naturais sejam mantidos, restaurados e melhorados" (PEARCE apud BENI, 1998, p.61). 
$\mathrm{Na}$ direção geral do empreendimento toda a família (os cinco proprietários) é responsável pelas decisões que afetam todo o hotel e estão relacionadas ao seu futuro.

Os principais clientes do hotel possuem idade entre 36 e 60 anos e procuram atividades culturais, de lazer e aventura. Os clientes são da cidade de São Paulo e da Grande São Paulo e ocupam, com mais freqüência, o hotel nos meses de dezembro, janeiro e julho respectivamente. A ocupação média estimada nesse período varia de $25 \%$ ( $2^{\mathrm{a}}$ a $6^{\mathrm{a}}$ feira) a $70 \%$ (finais de semana).

Quanto aos concorrentes, o hotel possui um concorrente direto (com o mesmo padrão de atendimento) que atua na região de Brotas. Em relação aos fornecedores, existem muitos e são locais e estaduais.

\subsubsection{Hotel B}

O hotel B foi fundado em 2002 e está localizado no centro de Brotas. Seu objetivo é fazer com que os hóspedes se sintam numa "ilha" para descansar do estresse urbano, vivendo um clima romântico. A pousada que também se considera um local especial para lua de mel, oferece café colonial, piscina, sauna, área de lazer, salão de eventos e 16 chalés de madeira com estacionamento individual. A pousada terceiriza os serviços de lavanderia e divulga os passeios externos que podem ser feitos na cidade.

Os proprietários da pousada têm formação acadêmica em engenharia e possuem outros negócios na área de engenharia e comércio. Atualmente, a pousada é considerada um investimento e não constitui atividade remunerada para os dois irmãos que são proprietários e possuem cada um $50 \%$ de participação no capital.

A pousada possui 5 funcionários além do gerente geral e da governanta que ocupam os únicos cargos administrativos do empreendimento. $\mathrm{O}$ organograma da empresa pode ser visualizado na figura 26.

Os principais clientes da pousada têm idade entre 15 a 35 anos e buscam atividades de aventura. Os clientes são da cidade de São Paulo (80\%) e da região (20\%) e ocupam com mais freqüência o hotel nos meses dezembro, janeiro e fevereiro respectivamente. A ocupação média estimada nesse período varia de $70 \%$ ( $2^{\mathrm{a}}$ a $6^{\mathrm{a}}$ feira) a $100 \%$ (finais de semana). 
O hotel considera grande o número de concorrentes que são todos locais. Em relação aos fornecedores, existem muitos e são locais e regionais.

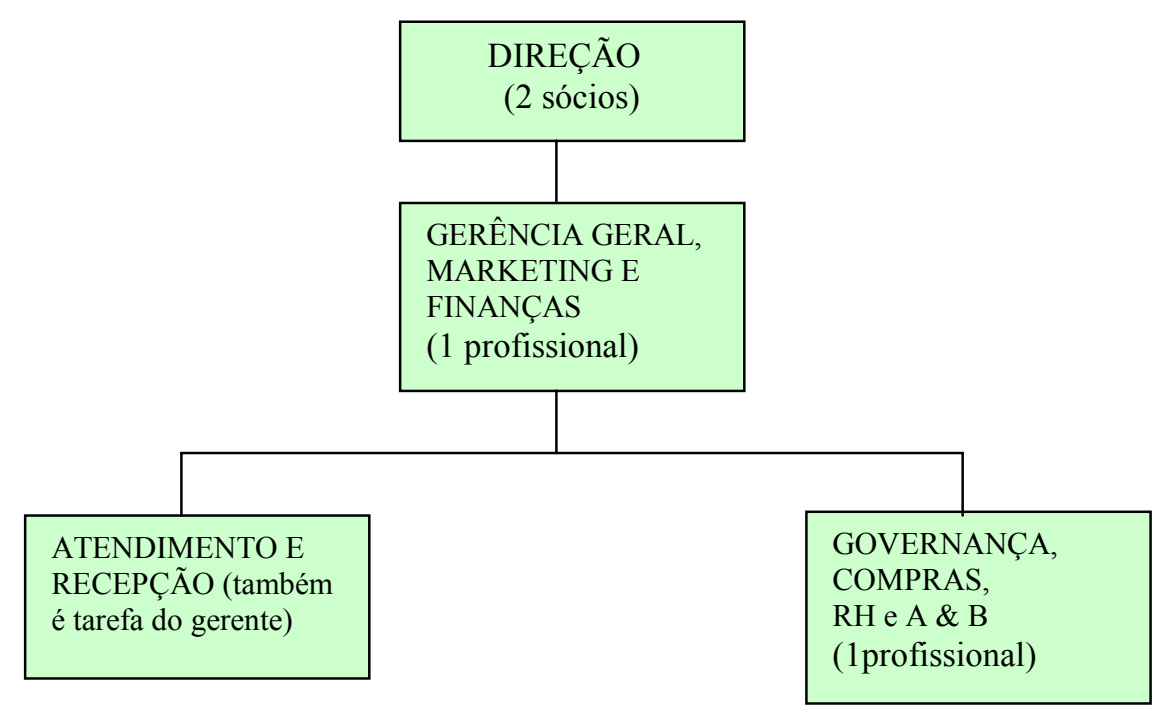

Figura 26 - Organograma do hotel B.

Fonte: elaboração própria

\subsubsection{Hotel C}

O hotel C foi fundado em 1979, e está localizado no centro da cidade de Brotas. Começou suas atividades recebendo os viajantes e hoje está voltado também para o turismo de aventura. Seu objetivo é fazer com que os hóspedes se sintam num ambiente familiar, oferecendo café da manhã, lavanderia, 25 apartamentos e 10 quartos e garagem. Além disso, faz agendamento de todas as atividades ligadas aos esportes radicais e atividades culturais.

O proprietário do hotel não dirige a empresa e desenvolve outras atividades de negócio. Sua participação é de $100 \%$ no capital da empresa. Atualmente a pousada é dirigida pela esposa e três filhos, sendo esta a única atividade remunerada desenvolvida pelos dirigentes.

A pousada possui 6 funcionários (incluindo a esposa e os três filhos). A direção geral é da esposa que coordena as atividades de outros três cargos administrativos desenvolvidos pelos filhos (figura 27). As ocupantes do cargo de Marketing e Finanças têm formação acadêmica em Turismo.

Os principais clientes do hotel possuem idade entre 15 e 35 anos e procuram atividades de aventura. Os clientes são da cidade de São Paulo (70\%) e da região (30\%) e ocupam com mais freqüência o hotel nos meses de dezembro, janeiro e feriados. A 
ocupação média estimada nesse período varia de $20 \%\left(2^{\mathrm{a}}\right.$ a $6^{\mathrm{a}}$ feira) a $70 \%$ (finais de semana).

Quanto aos concorrentes, o hotel possui um concorrente direto (com o mesmo padrão de atendimento) que atua na cidade de Brotas. Em relação aos fornecedores, existem muitos e são locais e regionais.

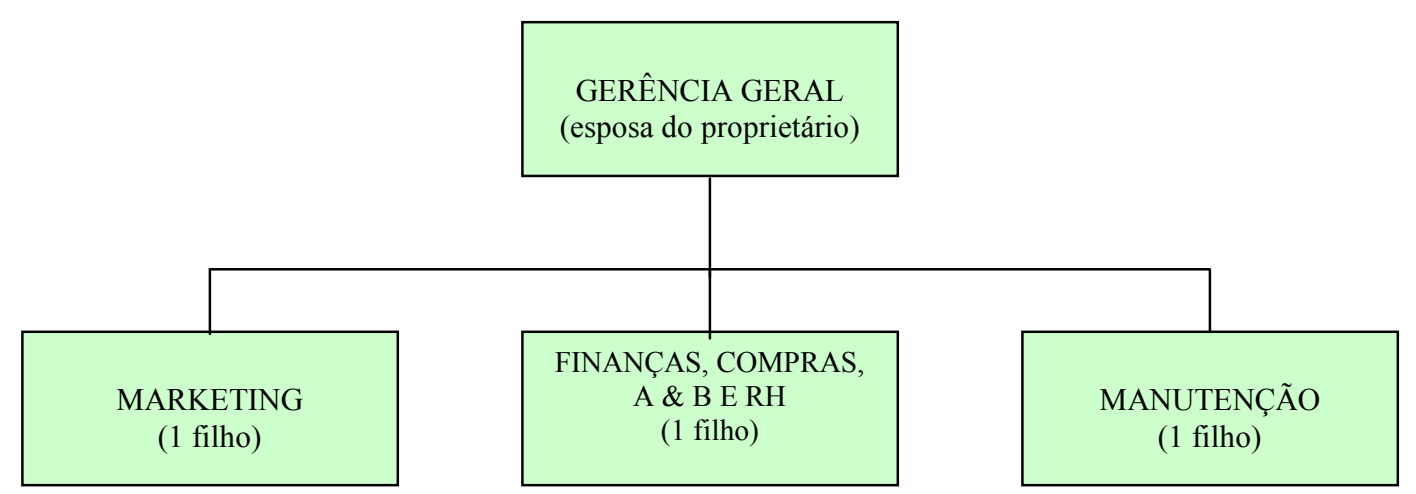

Figura 27 - Organograma do hotel C

Fonte: elaboração própria

\subsubsection{Hotel D}

O hotel D foi fundado em 1999, e está localizado numa área rural a 1,5 Km do centro da cidade de Brotas/SP. Seu objetivo (e da proprietária) é fazer com que os hóspedes se sintam parte da natureza, protegendo e deliciando-se com o que a pousada tem de melhor. A pousada que também, é um local de proteção aos animais, oferece lago para pesca esportiva, pomar, café colonial, área para churrasco, Happy hour ao ar livre, salão de jogos, piscina, monitoramento e serviço de babá, além de 14 chalés de madeira com tv, frigobar e ventilador, com capacidade para 54 pessoas. Além disso, a pousada faz agendamento para passeios externos, incluindo a participação nos esportes de aventura.

A proprietária da pousada tem formação acadêmica em Química Industrial, já possuiu outro negócio (loja de roupas) e também trabalhou em um hotel da família quando mais nova. Atualmente, sua única atividade remunerada está ligada às atividades da pousada e possui participação de $100 \%$ no capital da empresa.

A pousada possui 6 funcionários (incluindo dois filhos), além da dirigente (a proprietária) que ocupa o único cargo administrativo do empreendimento. $\mathrm{O}$ organograma da empresa pode ser visualizado na figura 28. 
A maioria dos clientes da empresa possui idade de 15 a 60 anos e busca atividades ligadas à saúde, ao lazer, culturais e de aventura. Esses clientes são do Estado de São Paulo, de outros estados da federação e até do exterior. Os clientes são mais freqüentes nos meses de: dezembro, janeiro, fevereiro, julho, outubro e novembro, respectivamente, ocupando $90 \%$ da pousada nos fins de semana e $10 \%$ de $2^{\mathrm{a}}$ a $6^{\mathrm{a}}$ feira.

Quanto aos concorrentes, a pousada possui dois concorrentes principais, um local e outro regional. Em relação aos fornecedores, existem muitos e são locais, regionais e estaduais.

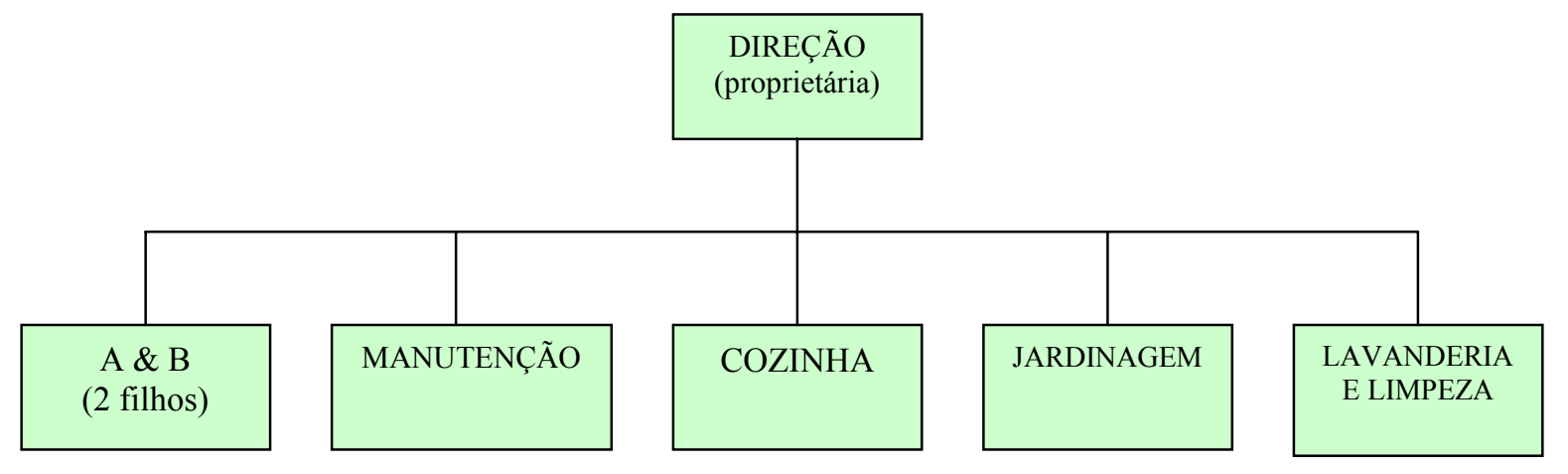

Figura 28 - Organograma do hotel D.

Fonte: elaboração própria

\subsubsection{Hotel $E$}

O hotel E iniciou suas atividades em 1965, e está localizado no centro de Águas de São Pedro/SP. Seu objetivo é desenvolver atividades relacionadas ao turismo de lazer, da saúde e cultural. Até 1994, o foco do hotel era atender o idoso com as águas medicinais. A partir de 1995, passou a explorar as atividades de lazer e culturais durante os fins de semanas.

O hotel tem um espaço de $17.000 \mathrm{~m} 2$ e oferece 33 tipos de serviços aos seus hóspedes. Os serviços principais estão relacionados às atividades de: lazer (minibosque, trilha para caminhada, quadra poliesportiva, piscinas etc.); tratamento da saúde (balneário e fontanário de águas para tratamento de saúde); acomodações (120 apartamentos); convenções para escolas, universidades e empresas (salões climatizados etc); restaurante (chef internacional, cardápio diversificado etc); outros serviços (salão de beleza, massagista, esteticista, copa da mamãe etc). 
O hotel tem dois proprietários, uma com $99 \%$ de participação no capital, não atua na direção do hotel e o outro com $1 \%$ de participação, atua na diretoria da empresa e desempenha outras atividades fora do hotel. O gerente geral é contador, há 36 anos, e sempre trabalhou em hotéis; há 5 anos, ocupa o cargo de gerente, sendo esta uma das duas atividades em que recebe remuneração. A outra atividade é cuidar da fazenda dos proprietários do hotel.

O hotel possui 66 funcionários que trabalham nos níveis de gerência geral, administrativo e operacional. No nível administrativo o hotel tem 11 chefias (figura 29). O hotel também tem em sua estrutura formal a diretoria que aprova os grandes investimentos propostos pela gerência geral.

Os principais clientes do hotel possuem idade de 15 a 60 anos e buscam atividades ligadas à saúde, ao lazer e culturais, 70\% são da cidade de São Paulo, ocupando o hotel com mais freqüencia nos meses de: dezembro, janeiro, e julho, com ocupação média estimada variando de 8 a $13 \%$ de $2^{\text {a }}$ a $6^{\text {a }}$ feira e $90 \%$ nos fins de semana.

Quanto aos concorrentes, o hotel possui três concorrentes principais, todos regionais. Em relação aos fornecedores, existem muitos, e são regionais.

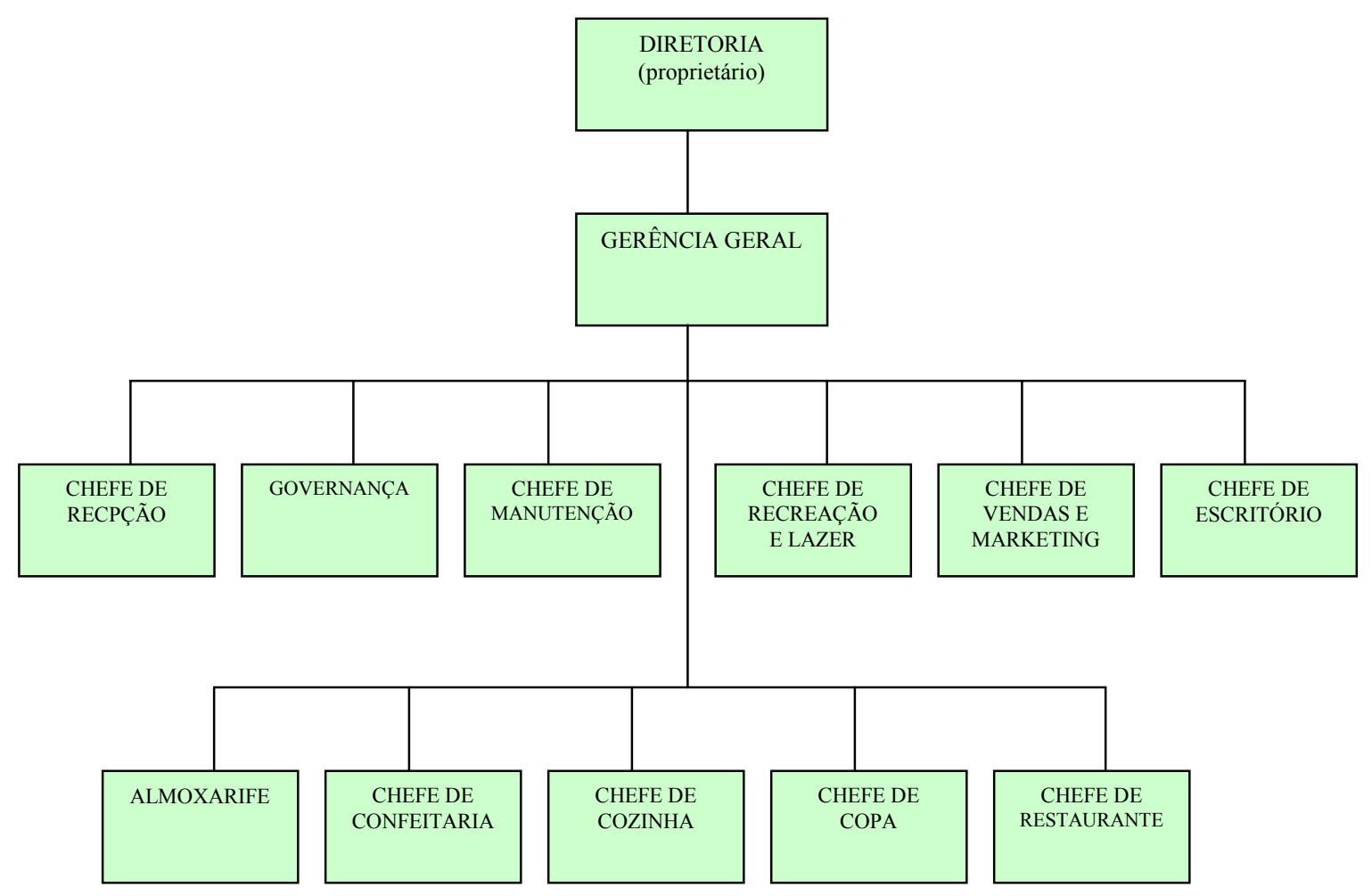

Figura 29 - Organograma do hotel E

Fonte: Gerente Geral do hotel 
A figura 30 apresenta os principais aspectos para caracterização dos empreendimentos hoteleiros.

\begin{tabular}{|c|c|c|c|c|c|}
\hline Aspectos gerais & Hotel A & Hotel B & Hotel C & Hotel D & Hotel E \\
\hline Localização & Brotas & Brotas & Brotas & Brotas & $\begin{array}{l}\text { Águas de } \\
\text { São Pedro }\end{array}$ \\
\hline Ano de fundação & 1995 & 2002 & 1979 & 1999 & 1965 \\
\hline $\mathrm{N}^{\mathrm{o}}$ de Unidades Habitacionais & 30 & 16 & 35 & 14 & 120 \\
\hline $\mathrm{N}^{\mathrm{o}}$ de Proprietários & 05 & 02 & 01 & 01 & 02 \\
\hline $\begin{array}{l}\mathrm{N}^{\mathrm{o}} \text { de Funcionários (níveis } \\
\text { operacional e administrativo) }\end{array}$ & 21 & 07 & 06 & 07 & 66 \\
\hline Idade dos principais clientes & 36 a 60 & 15 a 35 & 15 a 35 & 15 a 60 & 15 a 60 \\
\hline $\begin{array}{l}\text { Atividades procuradas pelos } \\
\text { clientes }\end{array}$ & $\begin{array}{l}\text { Culturais, } \\
\text { de Lazer e } \\
\text { Aventura }\end{array}$ & Aventura & Aventura & $\begin{array}{l}\text { Culturais, de } \\
\text { Lazer, Saúde } \\
\text { e Aventura }\end{array}$ & $\begin{array}{l}\text { Culturais, } \\
\text { de Saúde } \\
\text { e Lazer }\end{array}$ \\
\hline Concorrentes & Regionais & Locais & Locais & $\begin{array}{l}\text { Locais e } \\
\text { regionais }\end{array}$ & Regionais \\
\hline Fornecedores & $\begin{array}{l}\text { Locais e } \\
\text { estaduais }\end{array}$ & $\begin{array}{l}\text { Locais e } \\
\text { regionais }\end{array}$ & $\begin{array}{l}\text { Locais e } \\
\text { regionais }\end{array}$ & $\begin{array}{l}\text { Locais, } \\
\text { regionais e } \\
\text { estaduais }\end{array}$ & Regionais \\
\hline $\begin{array}{l}\text { Classificação ( } \mathrm{n}^{\circ} \text { de unidades } \\
\text { habitacionais) }\end{array}$ & $\begin{array}{l}\text { Pequeno } \\
\text { porte }\end{array}$ & Pequeno porte & Pequeno porte & Pequeno porte & $\begin{array}{l}\text { Médio } \\
\text { porte }\end{array}$ \\
\hline $\begin{array}{lll}\text { Classificação } & \left(\mathrm{n}^{\circ} \quad \mathrm{de}\right. \\
\text { funcionários }) & & \end{array}$ & $\begin{array}{l}\text { Pequena } \\
\text { empresa }\end{array}$ & Microempresa & Microempresa & Microempresa & $\begin{array}{c}\text { Média } \\
\text { empresa }\end{array}$ \\
\hline
\end{tabular}

Figura 30 - Caracterização dos empreendimentos hoteleiros

Fonte: elaboração própria 


\section{APRESENTAÇÃO E ANÁLISE DOS DADOS E PROPOSTAS DE MELHORIA}

O objetivo deste capítulo é apresentar e analisar os dados coletados nos cinco hotéis pesquisados e propor melhorias no processo de gerenciamento estratégico da informação. Foram investigadas as variáveis de pesquisas, conforme seção 4.2.3 do capítulo 4, mediante depoimento oral de dirigentes e funcionários (entrevistas formais semi-estruturadas e conversas informais) e pela observação livre do pesquisador. Essas variáveis, conceituadas a partir da revisão bibliográfica, são: análise estratégica da empresa (interna), informação estratégica (interna) e especificidades da pequena empresa. Uma descrição individual de cada empresa é apresentada nos apêndices D e E.

A partir da análise comparativa dos dados foi possível fazer algumas sugestões para a melhoria do processo de gestão estratégica das informações internas. Estas sugestões estão baseadas na metodologia apresentada na seção 4.3 do capítulo 4 e esquematizada na figura 22.

\subsection{Apresentação dos dados}

a) Análise estratégica

Segundo os dirigentes entrevistados, existe a preocupação com o planejamento estratégico, mas essa reflexão sobre o futuro do hotel é informal.

$\mathrm{Na}$ opinião do dirigente do hotel $\mathrm{A}$, possivelmente, não seja preciso formalizar a atividade de elaboração da estratégia, pois não é muito freqüente; diferentemente dos procedimentos utilizados pelas camareiras para arrumarem os quartos dos hóspedes. Para ele "a visão sobre o futuro da empresa cresce de acordo com o crescimento da conta bancária".

Para o dirigente do Hotel E, até o momento tem sido satisfatório o processo de pensar o futuro da empresa, mas não é o ideal, pois alguns investimentos são perdidos por falta de um plano de ação, como foi o caso do estacionamento subterrâneo (o hotel não possui estacionamento próprio). “Outras vezes, existe o plano, mas não é colocado 
em prática por falta de recursos financeiros", como as ações relacionadas à manutenção do hotel, que comprometem boa parte do faturamento.

A maior parte dos exemplos citados pelos dirigentes para ilustrar o que é uma decisão estratégica está relacionado ao atendimento de novos mercados ou a decisões de investimentos, como a construção de novas unidades habitacionais. Os entrevistados afirmam também que algumas estratégias surgem das conversas informais: entre os membros da família, como é o caso dos hotéis A e C; entre funcionários e direção ou da reflexão individual dos dirigentes.

Existe a visão de longo prazo, mas nada é escrito e todos os dirigentes imaginam como querem o hotel daqui a alguns anos. Os planos de investimentos estão em suas mentes. No caso do hotel A, esporadicamente, os planos são descritos nas atas de reuniões. As reuniões para discutir o futuro da empresa normalmente são informais, e "não existe uma data definida para que ocorra, é de acordo com o tempo dos integrantes da família e das necessidades do hotel", afirma o dirigente. No hotel C também, são realizadas reuniões entre a família, definindo-se as ações futuras da empresa. No entanto, não existe uma data definida para as reuniões e não há registro das ações definidas.

No hotel E, segundo o gerente, todos os meses, são realizadas reuniões na empresa para se discutir o plano estratégico. Junto com as chefias a gerência geral discute algumas idéias e são determinadas as prioridades e sua futura execução. No entanto, os objetivos e metas não são registrados em um documento e não são divulgados na empresa. A razão principal é a mudança constante dos objetivos que variam de acordo com as necessidades do hotel. Há também uma preocupação em todos os hotéis em ter um plano para toda a organização, para que todos corram atrás do mesmo objetivo.

A visão externa das empresas é operacionalizada principalmente pelo monitoramento da opinião dos clientes. Os hotéis estão preocupados também em identificar o que fazem de melhor em relação aos seus concorrentes e o que está ficando a desejar para melhor atender seus hóspedes, o que representa a visão interna do empreendimento. A dirigente do hotel $\mathrm{C}$ afirma que "atualmente a concorrência é com outras cidades e os hotéis não lotam mais como antigamente". A maioria das informações disponíveis é sobre o funcionamento dos hotéis. $\mathrm{Na}$ opinião dos entrevistados, estas são suficientes, para que se pense o futuro do empreendimento, 
existindo uma preocupação por parte dos dirigentes em analisar a situação financeira da empresa, antes da realização de qualquer investimento.

\section{b) Especificidades da pequena empresa}

Os dados coletados se referem às especificidades ambientais, estruturais, comportamentais do dirigente, tecnológicas e estratégicas, que foram mencionadas na seção anterior que fez a análise estratégica.

Quanto aos agentes do ambiente que podem influenciar as ações do hotel, os entrevistados citam os concorrentes, os clientes, os fornecedores, o poder público municipal e federal, os bancos e as entidades de classe.

Em relação à concorrência, os dirigentes dos hotéis acreditam que o mercado é competitivo. Para a dirigente do hotel $\mathrm{C}$ os grandes hotéis têm melhores condições de atrair os clientes por causa da estrutura. Já os dirigentes dos hotéis A, B e D acreditam ter um diferencial em relação aos grandes hotéis, um atendimento mais pessoal. Os fornecedores são muitos (locais e estaduais) e não oferecem no momento nenhuma ameaça aos hotéis. A proprietária do hotel $\mathrm{D}$ faz uma seleção criteriosa dos fornecedores (qualidade do produto, por exemplo), de acordo com os objetivos que a pousada procura atender, para não ter que ficar mudando de fornecedor. Quando a variável são os clientes, os dirigentes dos hotéis $\mathrm{C}$ e E, afirmam que estes, estão cada vez mais negociando os preços da hospedagem. Para o dirigente do hotel $\mathrm{B}$, a negociação ocorre apenas na baixa temporada, pois na alta temporada faltam chalés, e o que vale é a lei da oferta e da procura. Nos hotéis A e D, os clientes não costumam reclamar dos preços pagos pelos serviços, afirmam os dirigentes. Segundo o dirigente do hotel $\mathrm{E}$, os clientes têm valorizado mais o preço do que a qualidade e isto tem atrapalhado o negócio. Para ele o hotel de maior porte tem mais desvantagem quando o assunto é preço, pois o custo fixo é muito alto; só os funcionários são responsáveis por $85 \%$ desse custo.

Quanto às forças do macroambiente, inicialmente, foi falado sobre a situação econômica atual do país. Para os dirigentes, a recessão econômica tem diminuído a demanda, principalmente na baixa temporada. Com a incerteza da economia, viajar passou para o segundo plano dos turistas", afirma a dirigente do hotel C. Apenas no hotel A, "o cliente não deixou de freqüentar o hotel, como ocorreu com a maioria dos empreendimentos hoteleiros da cidade", afirma o dirigente. Os hotéis A e D, têm uma capacidade maior de passar por uma recessão, pois não buscam dinheiro em banco e 
continuam reinvestindo o capital. Nos hotéis B e E também existe a política de investir apenas com capital próprio, no entanto o hotel $\mathrm{E}$ apresenta limitações financeiras devido aos altos custos operacionais.

Quanto aos impostos municipais, todos os dirigentes afirmam que a alíquota de 5\% do ISS é muito alta. Os dirigentes se queixam, também, que os encargos trabalhistas pesam durante a baixa temporada, pois os custos com os funcionários permanecem os mesmos e a demanda diminui de forma significativa. Quanto às ações do poder público municipal, relacionadas à política de turismo, todos os dirigentes acreditam que a política é ineficaz, pois não consegue atrair o turista na baixa temporada. Os dirigentes também concordam que há uma grande dificuldade para unir os empresários do setor e apenas, os dirigentes dos hotéis A e C participam das reuniões do Conselho Municipal de Turismo. Na cidade de Águas de São Pedro ainda não existe COMTUR. O hotel A participa da Associação Brotas Capital da Aventura, apenas para divulgação da cidade em eventos. Enquanto o hotel E é sócio da Associação Brasileira da Indústria de Hotéis.

Os hotéis não possuem nenhuma relação com instituições de ensino, mas os dirigentes acreditam que elas poderiam contribuir com as empresas. "O problema é que elas estão fora da realidade, mas mesmo assim, às vezes oferecem alguns bons treinamentos e nos ajudam", afirma o gerente do hotel B. A dirigente do hotel C acredita que as instituições até capacitam os funcionários dos hotéis, no entanto ela afirma que o interesse maior não está direcionado aos empreendimentos de pequeno porte. Já a dirigente do hotel $\mathrm{D}$, afirma que as instituições de ensino são sonhadoras e formam pessoas para atuar numa realidade longe da brasileira. $\mathrm{O}$ curso de hotelaria de uma instituição renomada é ideal para quem quer trabalhar em grandes hotéis internacionais. Ela menciona também o caso dos estudantes de hotelaria da cidade de Piracicaba que fizeram estágio na sua pousada. “Os conhecimentos não eram aplicáveis no meu empreendimento, pois os estudantes foram preparados para atuarem em hotéis de grandes cidades".

Quanto aos bancos estes são apenas depositários dos recursos financeiros dos hotéis, pois "as taxas bancárias são altas, o atendimento é precário, os juros são altos $(2,9 \%$ a.m) e o limite de crédito disponível para investimento é de apenas R\$15.000,00", afirma a dirigente do hotel C. "Temos muitos projetos de ampliação da pousada na nossa cabeça, mas a restrição financeira nos impede de colocá-los em prática, ou seja, a realização dos investimentos necessários para o melhor atendimento do nosso cliente". 
Quanto às características estruturais típicas, os hotéis de pequeno porte possuem poucas unidades de trabalho no nível administrativo e são dirigidas pelos proprietários (hotéis A e D), pelos proprietários e gerentes (hotel B) ou pela família do proprietário (hotel C). O hotel E é dirigido pelo proprietário e pelo gerente geral.

Nos hotéis A, B e E, a autoridade é distribuída em níveis hierárquicos, conforme é demonstrado no organograma das empresas (figuras 25, 26 e 29), mas as principais decisões, como utilização de recursos financeiros, são tomadas apenas pela família (hotel A) e pela gerência geral e diretoria (hotel $\mathrm{B}$ e $\mathrm{E}$ ). No hotel $\mathrm{C}$, as decisões administrativas são da família e no hotel D da proprietária.

A comunicação é predominantemente oral em todos os hotéis, com exceção dos procedimentos para realização das tarefas operacionais existentes nos hotéis A e E. No hotel E, são realizadas reuniões com as chefias para elaborar o plano estratégico, analisar o trabalho realizado e discutir as pesquisas dos clientes entre outros assuntos. Nos demais hotéis, o conteúdo da comunicação oral é basicamente sobre os acontecimentos do dia-a-dia.

As atribuições dos funcionários são formalizadas (os procedimentos para realização das tarefas são estabelecidos e escritos) nos hotéis A e E. Para o dirigente do hotel A, esta formalização "facilita a cobrança" por parte dos dirigentes. Nos hotéis B, C e D as atribuições dos funcionários não são formalizadas, ou seja, os procedimentos para realização das tarefas não estão escritos, mas segundo os dirigentes todos sabem a sua responsabilidade. No entanto, segundo o gerente do hotel B, "quando o serviço aperta um ajuda o outro, pois a nossa estrutura é pequena, mas atende à necessidade de uma empresa que está começando". Cabe ressaltar que, nos hotéis A, C, D e E, existe por parte da empresa, uma preocupação com a qualificação do seu nível operacional e conseqüentemente uma observância dos requisitos para ocupar os cargos. Nos hotéis B e C, os ocupantes dos cargos administrativos realizam concomitantemente atividades operacionais e administrativas.

Quanto às especificidades comportamentais do dirigente, todos os dirigentes entrevistados demonstram vontade de realizar seus sonhos através da empresa. Características como honestidade e perseverança são consideradas importantes para quem dirige a empresa.

$\mathrm{Na}$ opinião dos dirigentes, quem dirige a empresa precisa adquirir conhecimentos e habilidades relacionados à hotelaria, gestão, turismo, finanças entre outros, para que seja possível compreender e administrar o hotel. O dirigente do hotel B, 
afirma que "às vezes ele tem iniciativa, mas não sabe como agir, ou seja, tenho uma idéia, mas não sei colocar em prática, falta-me conhecimento", afirma o gerente. Nós precisamos (a cidade de Brotas) de um curso sobre legislação, para que saibamos os direitos e deveres dos clientes. "Não precisa ser um curso universitário com 15 anos de duração", ironiza. Precisamos também de cursos (vendas, por exemplo) direcionados ao público do turismo, ou seja, específico para o nosso setor e suas peculiaridades. "Ser vendedor em uma loja de departamento é diferente de ser vendedor em um hotel". Para o gerente do hotel $\mathrm{B}$, em Brotas não há muita gente especializada em Turismo e isso faz com que apenas o atendimento diferenciado proporcione bom retorno financeiro.

Todos os dirigentes afirmam ser favoráveis à utilização de novas técnicas administrativas. No entanto, os dirigentes dos hotéis B, C e D (microempresas) afirmam que é necessário adequar essas técnicas à realidade da pequena empresa. $\mathrm{O}$ dirigente do hotel A, afirma que "é necessário conhecer os benefícios das técnicas, antes de sua aplicação". Mencionou inclusive que já contratou um consultor para implantar o programa de qualidade $5 \mathrm{~S}$ e que espera aprender algo de relevante para o negócio com a participação na pesquisa que está sendo desenvolvida. Os dirigentes também são favoráveis à utilização da T.I. nas atividades do hotel. $\mathrm{O}$ gerente do hotel $\mathrm{B}$, mencionou até a carência dessa tecnologia no check out dos hóspedes. A dirigente do hotel D, afirma que através da internet a pousada está sendo divulgada em Portugal, na França e em outros países da Europa. Já o gerente geral do hotel E afirma que a T.I. possibilita decisões mais rápidas. Para exemplificar, mencionou o tempo que se gasta hoje para fazer o fechamento do balanço patrimonial.

Quanto às especificidades tecnológicas, todos os hotéis utilizam telefone, fax, site na internet, software e computador. O hotel $\mathrm{D}$ utiliza também o programa hábil ${ }^{22}$ para registrar as operações financeiras. Já o hotel E utiliza um canal fechado de televisão, um banco de dados e um sistema de gerenciamento de transações. O hotel A utiliza nas operações do hotel rádio HT, para comunicação entre funcionários e Corta energia, que desliga a energia e informa a saída do hóspede do quarto para que se possa realizar a limpeza.

Nos hotéis A, B e D, o computador é utilizado para controle de gastos dos hóspedes, armazenamento de dados dos clientes, ou seja, na maior parte das vezes com a finalidade de contribuir para a realização e controle das operações da empresa. Já os

\footnotetext{
${ }^{22}$ Programa de computador disponível gratuitamente na internet que é utilizado para registrar as operações financeiras da empresa.
} 
sites das empresas, disponíveis na internet, são utilizados pelo cliente para cadastrar seus dados, obter informações sobre os eventos do hotel e fazer críticas.

Com exceção do hotel $\mathrm{B}$, todos os funcionários são treinados para utilização dos equipamentos e realização das tarefas. Nos hotéis A e E, reuniões são realizadas com os encarregados e com os funcionários da linha de frente para transmitir a melhor maneira de realização das tarefas, proporcionando o melhor atendimento ao turista. No hotel A, por exemplo, as camareiras são treinadas para entenderem, também, o trabalho dos monitores da área de lazer (atividades de campo), compreendendo o funcionamento total do hotel e prestando informações aos hóspedes. No hotel D, segundo a dirigente, os funcionários não iniciam as atividades antes de participarem do treinamento e, esporadicamente, participam de oficinas de turismo realizadas na cidade. Os funcionários, também, aprendem a interagir com outras pessoas, indo além de sua atividade técnica. Eles são capazes de prestar qualquer informação (interna) relativa ao hotel. As informações externas são de responsabilidade da proprietária.

Com exceção do hotel $\mathrm{C}$, as empresas estão sempre procurando conhecer novas tecnologias e buscar inovações; até mesmo na utilização de novas técnicas administrativas. "A inovação é o que move o hotel" diz o gerente do hotel E. Nós temos oito festas juninas e julinas e eventos exclusivos para a terceira idade (serestas). Para a dirigente do hotel $\mathrm{D}$, ela está inovando ao trabalhar com todas as agências de esportes radicais da cidade de Brotas. O turista não precisa se preocupar em agendar os passeios, tudo fica por conta do setor comercial do hotel. Para os dirigentes do hotel A e B, o empreendimento já nasceu diferenciado pelas suas instalações. Hoje, em todos os hotéis, a busca pela inovação está concentrada na diferenciação pelo atendimento.

\section{c) Informação estratégica (interna)}

Inicialmente foram identificados os tipos e fontes de informações (figura 31) que os hotéis utilizam para diagnosticar seus pontos fortes e seus pontos fracos.

Os dirigentes dos hotéis reconhecem a importância da informação para a administração do negócio. "Sem a informação ficamos, no escuro, sem saber que direção seguir. Que decisão tomar se não sabemos o que está acontecendo dentro e fora do hotel", afirma o dirigente do hotel A. A título de exemplo, o dirigente do hotel B mencionou o caso em que o hotel, sem base em informações, aumentou em $20 \%$ o preço da sua diária e a demanda começou a diminuir. Após a constatação do fato, fez uma 
pesquisa de preços e verificou que o valor da diária estava superestimado em relação à concorrência.

\begin{tabular}{|c|c|c|c|c|}
\hline $\begin{array}{c}\text { Atividades } \\
\text { do hotel }\end{array}$ & $\begin{array}{l}\text { Tipos de informação para } \\
\text { analisar recursose } \\
\text { capacidades do hotel no } \\
\text { momento atual }\end{array}$ & $\begin{array}{l}\text { Tipos de informação } \\
\text { para analisar o } \\
\text { desempenho atual do } \\
\text { hotel }\end{array}$ & $\begin{array}{c}\text { Grau de } \\
\text { importância } \\
\text { do tipo de } \\
\text { informação }\end{array}$ & $\begin{array}{l}\text { Fontes de } \\
\text { informação }\end{array}$ \\
\hline $\begin{array}{l}\text { Marketing } \\
\text { (comercial) }\end{array}$ & $\begin{array}{l}\text { - } \quad \text { Forma de pagamento (1) } \\
\text { (internet) } \\
\text { - } \quad \text { Tipo de produto } \\
\text { - } \quad \text { Peço } \\
\text { Vendas (7) }\end{array}$ & $\begin{array}{l}\text { - } \quad \text { Opinião dos clientes } \\
\text { - } \\
\text { Indice de retorno do } \\
\text { cliente (6) } \\
\text { Taxa de ocupação } \\
\text { (3) }\end{array}$ & Importante & $\begin{array}{ll}\text { - } & \begin{array}{l}\text { Clientes } \\
\text { (questionário) }\end{array} \\
\text { - } \quad \text { Folder (2) } \\
\text { - } \quad \text { Equipe de vendas } \\
\text { - } 3 \text { ) }\end{array}$ \\
\hline $\begin{array}{l}\text { Alimentos \& } \\
\text { Bebidas }\end{array}$ & $\begin{array}{ll}\text { - } & \text { Processo de produção } \\
\text { (procedimentos) } \\
\text { - } & \text { Higiene } \\
\text { - } & \text { Custo das mercadorias } \\
\text { - } & \text { Equipamentos } \\
\text { - } & \text { Arranjo físico (1) } \\
& \text { Diversificação de pratos } \\
& (2)\end{array}$ & $\begin{array}{ll}\text { - } & \text { Qualidade } \\
\text { - } & \text { Nível de estoque (8) } \\
\text { - } & \text { Refeições vendidas } \\
& \text { Opinião dos clientes }\end{array}$ & Importante & $\begin{array}{ll}\text { - } & \text { Funcionários } \\
\text { - } & \text { Observação } \\
\text { pessoal } \\
\text { - } & \begin{array}{l}\text { Clientes } \\
\text { (questionário) }\end{array} \\
\text { - } & \text { Mídia (3) }\end{array}$ \\
\hline Hospedagem & $\begin{array}{ll} & \text { Higiene e limpeza } \\
\text { - } & \text { Tecnologia de operação } \\
\text { (procedimentos) }\end{array}$ & $\begin{array}{ll}\text { - } & \text { Quantidade de } \\
& \text { Equipamentos } \\
& \text { funcionando (1) } \\
\text { - } & \text { Opinião dos clientes } \\
\text { - } & \text { Desperdício (3) }\end{array}$ & Importante & $\begin{array}{ll}\text { - } & \text { Funcionários } \\
\text { - } & \text { Observação } \\
\text { - } & \text { Cliensoal } \\
& \text { (questionário) }\end{array}$ \\
\hline $\begin{array}{l}\text { Administrativo } \\
\text { (finanças, } R H \\
\text { e outros) }\end{array}$ & 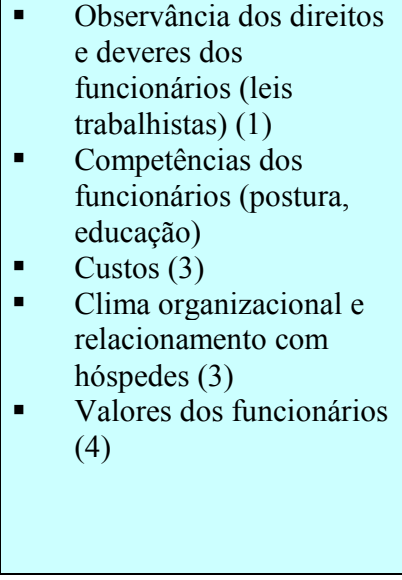 & $\begin{array}{l}\text { - } \begin{array}{l}\text { Opinião dos clientes } \\
\text { - }\end{array} \text { hontrole dos } \\
\text { hóspedes } \\
\text { Acompanhamento } \\
\text { do fluxo de caixa } \\
\text { diário } \\
\text { Gastos com } \\
\text { aquisição de } \\
\text { matéria-prima } \\
\text { (compras) } \\
\text { - } \quad \text { Produtividade (3) } \\
\text { - Lucro líquido (3) } \\
\text { Informações } \\
\text { financeiras do } \\
\text { software hábil (5) }\end{array}$ & Importante & $\begin{array}{ll}\text { - } & \text { Encarregados } \\
\text { Observação } \\
\text { - } & \text { Cliessoal } \\
& \text { (questionário) } \\
\text { - } & \text { Extrato Bancário } \\
& (1) \\
\text { - } & \text { Relatório de } \\
\text { gastos } & \text { Balanço } \\
\text { - } & \text { financeiro (3) } \\
\text { - } \quad \text { Sistemador }(9) \\
\text { - } & \text { Notaset } \\
\text { - } \quad \text { Livro caixa (5) } \\
\end{array}$ \\
\hline \multicolumn{5}{|c|}{$\begin{aligned} \text { Legenda: (1) apenas o hotel A } & \text { (2) apenas o hotel B } \\
\text { (4) apenas o hotel C } & \text { (5) apenas o hotel D } \\
\text { (7) hotel C e E } & \text { (8) hotel A e E }\end{aligned}$} \\
\hline
\end{tabular}

Figura 31 - Dados coletados nas entrevistas Fonte: elaboração própria 
Para a dirigente do hotel $\mathrm{C}$, a informação é a base que possibilita organizar o hotel e dividir as funções. "Sem a informação não é possível conduzir o negócio", fica muito difícil continuar na direção do objetivo. Eu busco informação por causa do negócio, se não fosse isso, eu queria viver só a natureza", afirma a dirigente do hotel D. Os benefícios da informação são inúmeros, desde a gestão de preços, vendas, determinação dos veículos de publicidade, até a análise dos retornos e determinação de prioridades para investimentos, afirma o gerente do hotel E. Para ele, "a velocidade das informações dão o ritmo para a administração e seu dinamismo".

Os responsáveis pelo acompanhamento das informações são a gerente de administração e o gerente de manutenção no hotel A, por estarem mais próximos dos funcionários e, também, por serem os representantes da empresa nas atividades externas, como participação em feiras e nas reuniões do COMTUR, concessão de entrevistas e atendimento a pesquisadores. Nos hotéis B, C e D, são, respectivamente, o gerente e os dirigentes, a gerente de finanças e a proprietária. No hotel E, são a gerência geral e os setores de marketing e de hospedagem (reservas e recepção). Segundo o gerente, a recepção coleta as informações sobre os concorrentes de forma estruturada.

Normalmente, os dados relativos ao negócio - que ajudam a melhorar o andamento do hotel e o atendimento aos hóspedes - são coletados em reuniões com funcionários e fora do hotel, pela observação pessoal e por meio do questionário preenchido pelos clientes. Não existe uma metodologia para coletar e organizar os dados de forma estruturada, afirma o gerente do hotel B. As informações são armazenadas principalmente na mente dos dirigentes, e às vezes em fichas, no caderno e no computador. No entanto, existe dificuldade para recuperar as informações quando são necessárias. No hotel $\mathrm{D}$, a recuperação das informações é realizada por meio de consulta às fichas dos clientes e ao programa hábil que registra as informações financeiras. Os dados mais organizados e considerados mais relevantes para os empreendimentos são os relativos à opinião dos clientes. Percebe-se, também, a preocupação em utilizar informações para avaliação da situação financeira das empresas, que é bastante relevante, quando se pensa em tomar decisões relativas a investimentos. Entretanto, a disponibilidade dessas informações é mínima nos hotéis de pequeno porte.

No hotel E, "os setores selecionam as informações, classificam-na por assuntos, discutem sua importância com a gerência e arquivam as informações relevantes (em papel - relatórios impressos, disquetes e no computador)", afirma o gerente. Por fim, são 
tomadas decisões com base nas informações pela gerência geral ou pela diretoria e depois, são apresentadas as implicações dessas decisões aos setores através de reuniões com os funcionários e de conversas informais entre gerente e chefes. No hotel A, as informações são apresentadas aos colaboradores através do fluxo diário de atividades, de reuniões com os funcionários, dos procedimentos formais para realização das tarefas e de conversas informais entre dirigentes e encarregados. No hotel B, as informações são apresentadas pelo gerente ao proprietário através do relatório de receitas e despesas e de conversas informais. No hotel $\mathrm{C}$, as informações são discutidas durante conversas informais entre os familiares e ajudam na definição do valor da diária, na escolha dos fornecedores, na melhora da infra-estrutura da pousada, na contratação de pessoal e na escolha das agências para estabelecer parcerias.

Quando foi perguntado aos dirigentes como as especificidades da pequena empresa podem influenciar a gestão da informação, os entrevistados citaram as seguintes características:

- A informalidade na comunicação e nas relações entre as pessoas dentro do hotel (hotel A);

- Falta de conhecimento por parte dos funcionários (hotel A e E)

- Falta de tempo por parte dos dirigentes (todos os hotéis);

- Carência de informações financeiras (hotel D);

- Falta de pessoas qualificadas para implantar o processo de gestão da informação (hotel A e B).

\subsection{Análise comparativa dos dados}

Antes da comparação dos hotéis de acordo com as variáveis de pesquisa, é importante relembrar a classificação do tamanho do hotel pelo número de unidades habitacionais e pelo número de funcionários. Pelo critério de unidades habitacionais, os hotéis $\mathrm{A}, \mathrm{B}, \mathrm{C}$ e D são de pequeno porte e o hotel E de médio porte. Pelo critério do número de funcionários os hotéis $\mathrm{B}, \mathrm{C}$ e $\mathrm{D}$ são microempresas, o hotel $\mathrm{A}$ uma pequena empresa e o hotel E uma média empresa.

a) Análise estratégica

Ao analisar o processo estratégico dos hotéis pesquisados, observa-se que em todos os empreendimentos a estratégia formulada para direcionar o negócio não é 
produto do planejamento formal, contrariando uma das premissas básicas em que se apóia a escola do planejamento (descritas na seção 2.1 do capítulo 2).

A estratégia pode ser concebida da reflexão individual de cada dirigente (hotéis A, B, C, D e E), das conversas informais entre dirigentes (A, B e C), das conversas informais entre dirigentes, funcionários e hóspedes (A, B, C, D e E), ou ainda das reuniões realizadas para a discutir o futuro do hotel (A e C). Não existe uma metodologia para ordenar as idéias e ações das pessoas participantes do processo e as alternativas surgem aleatoriamente a partir da análise dos fatos (dados e informações). Comprovando que a informalidade do processo de formulação da estratégia é uma especificidade do pequeno e, também, do médio empreendimento (figura 15, p.53).

A informalidade pode ser produto, principalmente, da própria crença do dirigente entrevistado e da falta de necessidade de formalizar a atividade de elaboração da estratégia (hotéis $\mathrm{A}, \mathrm{D}$ e E), embora tenha uma atitude favorável à aplicação de novas técnicas administrativas; ou do desconhecimento da técnica de planejamento estratégico (hotéis B e C).

Não há dúvida de que todos os dirigentes de hotéis pensam no futuro e que dispõem de um plano para trilhar o caminho desejado. Mesmo que esteja apenas na mente dos dirigentes, o plano possui um horizonte de longo prazo e é uma referência a ser seguida na empresa. O foco não é apenas no curto prazo, como foi descrito na figura 15 (p.53), mas também, na preparação do hotel para o futuro.

Para elaboração do plano, os dirigentes se preocupam com o que acontece dentro e fora do hotel. A visão externa é operacionalizada, principalmente, pela constante preocupação dos dirigentes em saber a opinião dos clientes, através de questionários preenchidos na saída do hotel após a prestação do serviço, ou pela página da empresa na internet para receber sugestões. Outras formas utilizadas pelos dirigentes para monitorar o comportamento das forças ambientais são: por meio do acompanhamento das ações dos concorrentes e pela participação em atividades relacionadas à atividade hoteleira, como as reuniões do COMTUR (hotéis A e C). A visão interna se materializa, quando os dirigentes compararam o que o hotel sob sua direção tem de melhor ou pior em relação aos concorrentes. Quanto as atividades de Marketing, são analisadas os preços praticados, os componentes do produto, a forma de promoção e de pagamento (hotel A), e a opinião dos clientes. Em relação a atividade de Alimentos \& Bebidas são examinados os procedimentos da operação, os equipamentos, os custo da mercadoria, a higiene, o arranjo físico (hotel A), a diversificação de pratos (hotel B), a qualidade, o 
nível de estoque (hotel A e E) e a quantidade de refeições vendidas (hotel A e E). Na atividade de Hospedagem, são observados os custos de manutenção, a tecnologia de operação, as instalações, os equipamentos, o desperdício (hotel E) e a quantidade de equipamentos funcionando (hotel A). Na atividade Administrativa, são analisados os aspectos financeiros e humanos. Nos aspectos financeiros, são observados o fluxo de caixa, o lucro líquido (hotel E) e os custos da matéria-prima. Nos aspectos humanos, são analisados a competência dos funcionários, os valores dos funcionários (hotel $\mathrm{C}$ ), o clima organizacional e o relacionamento com os hóspedes. Isto significa que os dirigentes identificam oportunidades e ameaças, pontos fortes e pontos fracos, que possam colaborar ou comprometer o sucesso do empreendimento, diferentemente das características citadas na figura 15 (p.53). Percebe-se, também, que muitas ações colocadas em prática pelos dirigentes dos hotéis, são reações às reclamações feitas pelos clientes, o que comprova, em parte, um comportamento reativo em relação ao ambiente. Que é um fato observado principalmente no hotel C.

Quanto à disponibilidade de informações para refletir sobre as forças do ambiente e sobre a situação atual da empresa, os hotéis possuem dados e informações coletados de forma parcialmente estruturada. Nos hotéis B, C e D a estruturação é menor do que nos hotéis A e E. O problema é muito mais de organização, do que de carência de dados e informações. O fato comprova que, em alguns momentos, há dificuldade dos dirigentes em recuperar as informações no momento oportuno, isto é, na hora da tomada de decisão.

\section{b) Especificidades da pequena empresa}

Percebe-se pelas entrevistas que o ambiente impõe restrições à atuação das empresas no mercado da hospitalidade, mas essa influência varia de um hotel para outro.

No macroambiente os hotéis são influenciados, principalmente, pela economia, pelos tributos e pelas ações da prefeitura. Sem sombra de dúvida, a inércia da economia é o que tem afetado mais os empreendimentos, por causa da diminuição da demanda, em especial, na baixa temporada. Mas os hotéis (A, B e D) que têm uma capacidade financeira para enfrentar a queda da demanda, não tiveram seus objetivos comprometidos na totalidade. Dois deles ainda realizaram investimentos com capital próprio em infra-estrutura (A e D). 
Quanto aos tributos, todos os dirigentes reconhecem que são excessivos e que pesam no orçamento, principalmente, na baixa temporada, devido à diminuição da demanda e permanência dos custos fixos de mão-de-obra. Em dois dos hotéis (C e E) a reclamação foi mais enfática. São hotéis mais sensíveis à queda da demanda e que não têm capacidade de investimento, por causa das restrições financeiras.

Para a maioria dos dirigentes (exceto o hotel C), a prefeitura não cumpre o seu papel de agente fomentador do turismo. A queixa é que as políticas municipais não divulgam a cidade e são ineficazes na atração do turista. Até nas reuniões do COMTUR (Brotas) que é dominado pela prefeitura os hoteleiros não se entendem e muito menos compreendem o poder público municipal, afirmam os empresários. Apenas os dirigentes dos hotéis A e C participam das reuniões do Conselho Municipal de Turismo.

Os bancos são apenas depositários dos recursos financeiros das empresas. Quatro dos hotéis (A, B, D e E) pesquisados possuem a política de investimento apenas com capital próprio e não recorrem à pouca disponibilidade de crédito e aos juros excessivos oferecidos pelos bancos. Apenas o hotel $\mathrm{C}$ recorreu ao banco e captou recursos para ser utilizado como capital de giro na empresa.

Em relação aos conhecimentos sobre gestão de hotéis, turismo e outros ensinados pelas instituições de ensino, três dos hotéis pesquisados (B, C e D) afirmam que esses conhecimentos estão fora da realidade da pequena empresa. A mão-de-obra preparada por estes estabelecimentos não conhece as características típicas da pequena empresa que irão influenciar a sua gestão. Cabe destacar que se for considerada a classificação pelo número de funcionários, os três hotéis citados são considerados microempresas.

No ambiente operacional os hotéis interagem, predominantemente, com os clientes, fornecedores, concorrentes e entidades de classe. Quanto aos clientes, de forma geral, houve diminuição da freqüência de hospedagem, mas a demanda ainda continuou satisfatória para as pretensões dos hotéis A, B e D. O mesmo não aconteceu em relação aos hotéis $\mathrm{C}$ e $\mathrm{E}$ que são mais sensíveis à diminuição da demanda, por causa das restrições financeiras. No caso do hotel E, a situação é ainda mais complicada, pois 85\% dos seus custos fixos são relativos à mão-de-obra. Como na baixa temporada a redução da demanda é significativa, a ociosidade dos seus recursos é muito grande, pois não é possível estocar hospedagem.

Os fornecedores não impõem restrições aos hotéis pesquisados, pois são muitos e o mercado é concorrido. Possuem um poder relativamente baixo durante as 
negociações. Quanto à concorrência, percebe-se que na cidade de Brotas o mercado é bastante competitivo durante a baixa temporada. $\mathrm{Na}$ alta temporada e feriados, os preços são majorados e, mesmo assim, faltam leitos para os hóspedes que procuram a cidade. Nenhum dos quatro hoteleiros entrevistados, na cidade de Brotas, culpam a concorrência pela queda na demanda, como também, não enxergam os outros hotéis como uma ameaça ao sucesso de seus empreendimentos. No caso do hotel E, que fica na cidade de Águas de São Pedro, o dirigente acredita que o mercado é pouco competitivo e há espaço para instalação de um hotel de rede, pois só assim atrairia mais turistas para a cidade. $\mathrm{O}$ dirigente ressalta também a desvantagem que os hotéis maiores têm em termos de custos nos períodos de baixa demanda.

Em relação às entidades de classe, apenas o hotel A participa de uma entidade cuja finalidade é apenas arrecadar fundos para divulgar a cidade de Brotas em feiras relacionadas ao turismo.

Quanto às especificidades estruturais, todas as características citadas na revisão bibliográfica foram encontradas no hotel $\mathrm{B}$ e sete das oito características nos hotéis $\mathrm{A}, \mathrm{C}$ e $\mathrm{D}$, com exceção do item que relata a mínima preocupação da pequena empresa em contratar pessoas que preencham os requisitos básicos para ocupar um cargo. No hotel E, manifestam-se quatro especificidades: poucos níveis hierárquicos, facilidade de controle, escopo de cargo abrangente da gerência e a existência do contato direto e informal entre gerente, funcionários e hóspedes.

Os hotéis (A, B, C e D) possuem poucas unidades de trabalho e os dirigentes desses hotéis têm muitas atribuições (A, B, C, D e E). Por isso, na maior parte dos momentos, o tempo disponível é escasso para o aprendizado e aplicação de novas técnicas administrativas (metodologia de planejamento estratégico e gestão da informação).

A autoridade é distribuída em níveis hierárquicos e centralizada na família (hotel A e C), na proprietária (D), e nos proprietários e no gerente (B e E). Com base nessa autoridade, os dirigentes são responsáveis pelas decisões estratégicas da empresa, por sua implementação e pelo controle dos resultados. Esses dirigentes, também, tomam decisões no nível operacional (estabelecer procedimentos escritos ou não), mas com a participação dos funcionários que irão executar as tarefas. Outra característica que não foi citada na revisão teórica é a formalização dos procedimentos (nível operacional) no hotel A. Esta especificidade facilita o controle de funcionários e dos resultados pelos 
dirigentes. Cabe ressaltar que apenas as microempresas não possuem procedimentos formalizados para o nível operacional.

A comunicação é predominantemente oral (hotéis A,B, C, D e E), com exceção dos procedimentos (A e E) e seu conteúdo refere-se basicamente à distribuição de tarefas.

Quanto às especificidades comportamentais do dirigente, é explícita a atitude favorável dos dirigentes de quatro hotéis $(\mathrm{A}, \mathrm{B}, \mathrm{C}$ e E) à utilização de novas técnicas administrativas no negócio, diferente do que foi constatado na revisão bibliográfica (figura 14). Algumas razões explicam esta atitude: o nível de escolaridade dos dirigentes; o reconhecimento da necessidade que todo dirigente tem de aprender conhecimentos e habilidades relacionados à gestão de hotéis, finanças e turismo entre outros; além da receptividade dos dirigentes aos pesquisadores do GEOPE. Apenas a dirigente do hotel $\mathrm{D}$ não demonstrou, durante as entrevistas uma atitude favorável à utilização de novos conhecimentos, apesar de ela afirmar que tem. Há um certo ceticismo de sua parte, quanto à aplicabilidade dessas técnicas aos pequenos empreendimentos. Essa atitude é decorrente de suas próprias experiências como dirigente de pousada.

Outro ponto positivo, no comportamento de todos os dirigentes, é a aceitação da utilização da tecnologia da informação para desenvolver as atividades do hotel. O que contribui para o desenvolvimento de um processo de gestão das informações disponíveis dentro da própria empresa.

Quanto às características pessoais dos dirigentes, destaca-se o desejo de realização dos dirigentes dos hotéis A, B, C, D e E. Em relação aos hotéis A, B, C e E, essa característica se materializa com o objetivo de crescimento dos hotéis. Quanto à dirigente do hotel $\mathrm{D}$, ela não deseja que o hotel cresça além da sua meta de atender sessenta hóspedes simultaneamente. Se isto acontecer, o seu sonho de ver a pousada como extensão da família não será mais possível, pois o seu contato com o turista deixará de ser direto e mais informal. A dirigente quer se alegrar com o turista, mas chorar se for preciso também. É esse ambiente familiar que ela deseja e luta para que permaneça dentro da sua pousada.

Quanto às especificidades tecnológicas, os dirigentes dos hotéis (A, B, D e E) estão sempre procurando incrementar alguma mudança no atendimento, seja relacionada às técnicas de operação ou aos equipamentos utilizados para prestar o serviço ao cliente. Em todos esses hotéis a busca pela inovação é no atendimento, este deve ser o 
diferencial em relação à concorrência. Para isso, os dirigentes utilizam como instrumento o treinamento dos funcionários (entre outros) para interagir com os hóspedes. Isto permite também uma aproximação maior dos clientes, e pode se transformar numa boa fonte de informações. O objetivo dos hotéis é sempre se aproximar, ao máximo, do serviço personalizado.

No caso do hotel $\mathrm{C}$, embora a dirigente procure também a diferenciação no atendimento, ela não está preocupada em desenvolver algo novo, mas apenas em "atender as necessidades primárias dos hóspedes". A empresa se torna muito mais dependente das condições favoráveis do ambiente e muito menos do esforço do hotel em criar algo de diferente para atrair os hóspedes. Isto não significa que a empresa não possa ter uma posição diferenciada no mercado, mas é um sinal do seu comportamento reagente em relação às forças ambientais. Esta é a estratégia escolhida pela família para dirigir o negócio.

Quanto às instalações, equipamentos e processos utilizados nos hotéis, estes não apresentam sofisticação como nos grandes hotéis, mas também não são obsoletos como foi citado na revisão bibliográfica, embora, no hotel $\mathrm{E}$, as suas instalações representem um ponto fraco. A diversidade da estrutura desses hotéis é muito grande, mas todos têm uma tecnologia mais simples e isto não é sinônimo de prestação de serviço de má qualidade.

Com relação à tecnologia da informação, todas as ferramentas utilizadas visam, predominantemente, contribuir para a realização e controle das operações do hotel. A internet também é utilizada, como um instrumento de coleta de informações, onde os hóspedes podem entrar em contato com os hotéis e fazer críticas ou propor sugestões. No entanto, os dirigentes dos hotéis (A, B, C e D) não têm plena consciência de que essa tecnologia possa ser usada para gerenciar informações ou ser um instrumento que proporcione vantagem competitiva ao empreendimento. Quanto ao hotel E, a T. I. já fornece algumas informações úteis ao plano estratégico, mas a tecnologia não é utilizada com a finalidade de gerenciar informações estratégicas. Esta constatação pode evidenciar duas coisas: a limitação do conhecimento de gestão da informação dos dirigentes de hotéis e a existência de um instrumento facilitador da implantação de uma metodologia de gerenciamento estratégico da informação. 


\section{c) Informação estratégica (interna)}

Todos os dirigentes de hotel têm consciência da importância da informação para o sucesso do negócio. As afirmações desses dirigentes, durante as entrevistas, não deixam nenhuma dúvida da relevância da informação para as suas decisões relacionadas ao gerenciamento dos empreendimentos. As empresas carecem mais da organização dos dados, em especial dos financeiros (hotéis A, B, C e D), como foi relatado pelos dirigentes.

Os hotéis B, C e D (microempresas) realizam as etapas do processo de gestão da informação de maneira informal e com pouca estruturação; com um maior grau de estruturação os hotéis A e E, também, fazem o gerenciamento da informação. Com relação ao diagnóstico da real necessidade dos tipos e fontes de informação úteis ao tomador de decisão, todos os hotéis possuem uma base de dados incompleta principalmente, quando se trata das informações que irão avaliar o desempenho das áreas principais (chave) do negócio. Esta carência é mais evidente nas microempresas.

Esta etapa de identificação das informações é fundamental para o sucesso do processo de gestão da informação. Com exceção do dirigente do hotel E, os demais dirigentes de hotel não têm plena consciência de que as informações coletadas devem proporcionar uma radiografia da situação atual da empresa, de forma a avaliar a quantidade e qualidade de seus recursos, bem como as habilidades para administrar esses recursos e o desempenho passado e atual do hotel.

Em relação à etapa de coleta dos dados e informações, todos os hotéis utilizam mecanismos manuais e eletrônicos para realizar esta tarefa. Quando a informação é sobre os clientes ou sobre a concorrência essa tarefa é realizada de forma sistemática, estruturada ou não.

$\mathrm{Na}$ etapa de processamento, é que os hotéis apresentam as maiores dificuldades. Nos hotéis A, B, C e D, as informações estão dispersas e não circulam de forma organizada na empresa, dificultando a sua recuperação pelos tomadores de decisão. Esses hotéis precisam tratar a informação, isto é, registrar, apreciar seu conteúdo e elaborar sínteses úteis a quem toma as decisões. No hotel E, já existe um processo informal para tratar os dados, mas algumas informações importantes ainda não foram identificadas pelos dirigentes.

Os dados e informações relevantes são armazenados, preferencialmente, na mente dos dirigentes (hotéis A, B, C e D), mas também em papel (fichas), disquetes e 
no disco rígido do computador. No hotel E, a predominância é pela utilização da memória organizacional (relatórios impressos, microcomputador etc).

Com relação à etapa de disseminação de dados e informações, as conversas informais entre os dirigentes e funcionários dos hotéis $\mathrm{A}, \mathrm{B}, \mathrm{C}$ e $\mathrm{D}$, são, predominantemente, utilizadas para realizar esta etapa. No hotel E além das conversas entre gerente e chefias, acontece reuniões mensais onde são transmitidas as informações úteis para a tomada de decisão do gerente. No entanto, nada impede que os dirigentes dos hotéis recebam as informações apresentadas de outras formas (gráficos, tabelas etc), mesmo que seja durante reuniões mensais ou conversas informais.

Mesmo de forma desestruturada ou parcialmente estruturada, os dirigentes produzem informações e incorporam-nas ao processo decisório ao refletir sobre o futuro do hotel. Quando esses dirigentes pensam sobre os concorrentes, ou ouvem e lêem a opinião dos clientes, ou quando conversam com seus funcionários, eles estão coletando e interpretando dados e produzindo informações que possam ajudar na identificação de pontos fortes e pontos fracos de suas empresas. Mesmo sem a utilização de uma metodologia pré-estabelecida, há a produção de informação e esta é utilizada pelos dirigentes na tomada de decisão.

Após a análise dos dados, é possível identificar algumas características dos hotéis que podem facilitar ou dificultar a melhoria do processo de gestão da informação nestes empreendimentos. Para facilitar o processo ou minimizar as dificuldades, pode-se citar:

- A utilização da T.I. nas atividades operacionais do hotel (todos os hotéis);

- A realização de forma mais estruturada da coleta de informações (hotéis A e E);

- A facilidade de obter informações (hotel E);

- A utilização de um sistema de gerenciamento das operações do hotel (hotel E);

- A visão de futuro da empresa (todos os hotéis);

- O desejo de melhorar sempre o atendimento (todos os hotéis);

- A formalização de alguns procedimentos (hotéis A e E);

- A centralização das decisões estratégicas (a própria adoção do processo de melhoria no gerenciamento da informação é uma decisão estratégica para o hotel) (todos os hotéis);

- A atitude favorável dos dirigentes para utilizar novas técnicas de administração (exceto o hotel D);

- O desejo do dirigente em adquirir novos conhecimentos (todos os hotéis). 
Algumas características que podem dificultar são:

- Falta de tempo por parte dos dirigentes (todos os hotéis);

- Falta de conhecimento da gerência (hotéis A, B, C e D);

- A carência de informações (hotéis B, C e D);

- Falta de recursos financeiros para contratar alguém para ajudar o gerente geral (hotel E).

\subsection{Propostas de melhoria no gerenciamento da informação interna}

A análise comparativa de dados demonstra que os hotéis pesquisados apresentam mais facilidades do que dificuldades para implantação de um processo de melhoria do gerenciamento estratégico das informações. Isto aumenta a probabilidade de auxiliar os dirigentes dos hotéis na organização das atividades de identificação, coleta, processamento, disseminação e utilização de dados e informações (figura 32), visando a análise interna da empresa e diagnóstico de seus pontos fortes e fracos.

\begin{tabular}{|c|l|}
\hline $\begin{array}{c}\text { Etapas do processo } \\
\text { de gerenciamento } \\
\text { da informação } \\
\text { (figura 22) }\end{array}$ & \multicolumn{1}{|c|}{$\begin{array}{l}\text { PROPOSTAS DE MELHORIA } \\
\text { nas etapas do processo de gerenciamento da informação }\end{array}$} \\
\hline $1^{\text {a Etapa }}$ & $\begin{array}{l}\text { Conscientizar os dirigentes da relevância do processo de gerenciamento da } \\
\text { informação }\end{array}$ \\
\hline $2^{\text {a Etapa }}$ & $\begin{array}{l}\text { Identificar as informações estratégicas a partir da compreensão do funcionamento } \\
\text { do hotel }\end{array}$ \\
\hline $3^{\text {a Etapa }}$ & $\begin{array}{l}\text { Aperfeiçoar os instrumentos de coleta; priorizando a captação dos dados relativos } \\
\text { às áreas essenciais para realização dos objetivos }\end{array}$ \\
\hline $4^{\text {a }}$ Etapa & $\begin{array}{l}\text { Registrar, apreciar e consolidar os dados que estão dispersos e circulando, de } \\
\text { forma desorganizada, na empresa e ampliar a memória organizacional do hotel }\end{array}$ \\
\hline $5^{\text {a }}$ Etapa & $\begin{array}{l}\text { Exibir as informações no formato de relatórios, formulários ou gráficos na tela do } \\
\text { computador ou impressos em papel }\end{array}$ \\
\hline
\end{tabular}

Figura 32 - Propostas de melhoria para o gerenciamento estratégico da informação

Fonte: elaboração própria 
A primeira proposta é conscientizar os dirigentes da relevância do processo de gerenciamento da informação, ou seja, da necessidade de sistematizar as atividades de coleta, processamento e distribuição de dados e informações. A proposta se justifica pela produção desordenada de informações, isto é, as etapas do processo de gerenciamento da informação não são conscientemente delimitadas. Outra justificativa está relacionada ao real conhecimento dos benefícios do gerenciamento da informação. Mesmo reconhecendo a importância da informação para o sucesso do negócio, os benefícios do seu gerenciamento ainda não estão visíveis aos dirigentes das pequenas empresas.

Uma das formas de alcançar este objetivo é mostrar a aplicabilidade deste instrumento na pequena empresa e os benefícios resultantes de sua utilização. No caso do hotel de médio porte, conscientizar também os colaboradores do gerente geral. Como os dirigentes já têm o desejo de adquirir novos conhecimentos, uma parceria entre os hotéis e universidades e instituições como Sebrae e Senac, com ou sem mediação da prefeitura, possibilitariam criar cursos direcionados à conscientização dos dirigentes sobre os benefícios do processo de gerenciamento estratégico da informação.

A segunda proposta está relacionada à etapa de identificação das necessidades de informação do tomador de decisão. Os dirigentes precisam entender o funcionamento do seu negócio, para que consigam diagnosticar: os tipos de informações que realmente são úteis a análise dos aspectos internos do hotel; as informações necessárias para avaliar a quantidade e qualidade dos recursos disponíveis; a capacidade de gestão desses recursos; e o desempenho passado e atual das atividades mais importantes para a realização dos objetivos do hotel.

A justificativa desta proposta está baseada no fato de que existem informações disponíveis nos hotéis, mas ainda não foram identificadas como relevantes pelos dirigentes, prevalecendo uma carência maior de indicadores financeiros, ou não, para avaliar o desempenho atual das áreas chave do negócio. Alguns dados estão disponíveis na empresa, mas não são combinados para obtenção do indicador de desempenho e outros não estão à disposição do tomador de decisão. Como na proposição de número um e nas demais propostas, podem ser estabelecidas parcerias com instituições de ensino, que ajudem os dirigentes no diagnóstico das informações que são úteis à análise estratégica (interna) do hotel. Outra possibilidade é a contratação de um consultor pelas empresas para realização dessa etapa e das demais. 
O atendimento, por exemplo, é uma das atividades que carece de maior atenção ao seu desempenho. Propõe-se a utilização de três indicadores não econômicos que podem demonstrar se os hotéis realmente estão procurando melhorar o atendimento aos clientes: realização e formas de treinamento, serviços oferecidos aos clientes e relacionamento com a clientela, entre outros. Nenhum desses indicadores citados apresentam uma fórmula ou expressão geral para representá-lo, mas são de fácil entendimento pelo dirigente da pequena empresa e permitem acompanhar a evolução do próprio indicador na empresa e compará-lo com hotéis concorrentes.

Outro aspecto crítico no hotel e que foi citado pelos dirigentes é a área financeira. Apenas, o hotel $\mathrm{E}$ dispõe de informações que permitem analisar com mais precisão este aspecto. Três indicadores que podem ajudar o dirigente a entender a capacidade financeira do hotel são: o faturamento, o índice de cobertura de juros e a margem bruta da empresa, entre outras opções. No caso da área financeira, uma segunda opção, para ajudar os dirigentes na interpretação dos dados, é o diálogo com os contadores do hotel. Atualmente, os cursos de contabilidade, também, procuram dar ênfase à contabilidade gerencial, o que pode contribuir na análise dos dados financeiros. É importante ressaltar, que antes da utilização do indicador de desempenho é preciso entender o que ele significa e quais as informações que são necessárias para a sua composição, quando for o caso (figura 33).

\begin{tabular}{|c|c|c|}
\hline $\begin{array}{l}\text { INDICADOR DE } \\
\text { DESEMPENHO }\end{array}$ & INFORMAÇÕES BÁSICAS & SIGNIFICADO \\
\hline $\begin{array}{l}\text { Índice de ocupação } \\
\text { do hotel }\end{array}$ & $\begin{array}{ll}\text { - } & \text { Apartamentos vendidos } \\
\text { - } & \text { Apartamentos disponíveis }\end{array}$ & $\begin{array}{l}\text { Mostra a quantidade de apartamentos } \\
\text { ocupados em relação ao total } \\
\text { disponível e é uma medida de } \\
\text { produtividade da área comercial }\end{array}$ \\
\hline $\begin{array}{l}\text { Realização e } \\
\text { formas de } \\
\text { treinamento }\end{array}$ & - Quantidade de treinamento realizada & $\begin{array}{l}\text { Demonstra a preocupação em melhorar } \\
\text { o atendimento ao cliente através da } \\
\text { qualificação contínua da mão-de-obra }\end{array}$ \\
\hline $\begin{array}{c}\text { Serviços } \\
\text { oferecidos aos } \\
\text { clientes }\end{array}$ & $\begin{array}{l}\text { - Quantidade de serviços agregados ao } \\
\text { benefício principal do produto oferecido } \\
\text { pelo hotel }\end{array}$ & $\begin{array}{l}\text { Indica os serviços agregados ao } \\
\text { produto vendido reconhecido como } \\
\text { valor pelo cliente }\end{array}$ \\
\hline $\begin{array}{l}\text { Relacionamento } \\
\text { com a clientela }\end{array}$ & $\begin{array}{l}\text { - Quantidade de canais de comunicação à } \\
\text { disposição do cliente para se comunicar } \\
\text { com o hotel }\end{array}$ & $\begin{array}{l}\text { Representa os canais de comunicação } \\
\text { entre o hotel e os hóspedes }\end{array}$ \\
\hline Faturamento & - Valor total das vendas & $\begin{array}{l}\text { Indica o valor total arrecadado pelo } \\
\text { hotel }\end{array}$ \\
\hline $\begin{array}{c}\text { Índice de cobertura } \\
\text { de juros } \\
\end{array}$ & $\begin{array}{ll}\text { - } & \text { Lucro antes dos juros e I.R. } \\
\text { - } & \text { Despesa anual de juros } \\
\end{array}$ & $\begin{array}{l}\text { Mede a capacidade da empresa de } \\
\text { pagar juros contratuais }\end{array}$ \\
\hline Margem bruta & $\begin{array}{ll} & \text { Custos } \\
\text { - } & \text { Vendas }\end{array}$ & $\begin{array}{l}\text { Determina a porcentagem de cada real } \\
\text { de venda restante após a dedução de } \\
\text { todos os custos }\end{array}$ \\
\hline
\end{tabular}

Figura 33 - Características dos indicadores de desempenho

Fonte: elaboração própria 
A terceira proposta está relacionada à etapa de coleta de dados. Os dirigentes podem aperfeiçoar os mecanismos manuais e eletrônicos atuais para coletar os dados, priorizando a aquisição dos dados relacionados apenas às áreas essenciais para o bom andamento do hotel, ou seja, os dados identificados na etapa anterior. Esta proposta é justificada pela possibilidade de aumentar a quantidade dos instrumentos de coleta e dos tipos de dados coletados, como é o caso do exemplo da variável cliente citada no parágrafo abaixo.

No caso dos clientes, as microempresas podem realizar a coleta de dados mediante um formulário que permita ao hóspede fazer observações sobre as áreas essenciais para a realização dos objetivos do empreendimento. Esse questionário pode ser deixado no quarto do hotel.

Quanto à concorrência, os dirigentes podem fazer uma lista de checagem dos aspectos essenciais para funcionamento do hotel e comparar e coletar apenas os dados relacionados a esses fatores. Pela formação escolar e conhecimentos demonstrados durante as entrevistas, os próprios dirigentes dos hotéis podem elaborar, por meio da leitura de livros sobre gestão de hotéis, a lista de checagem para monitorar a concorrência e identificar os pontos fortes e fracos do empreendimento.

Outra maneira de aperfeiçoar os mecanismos de coleta é preparar os funcionários para captarem dados relativos ao negócio. Essa preparação pode ser oferecida pelos próprios dirigentes por meio de palestras e reuniões regulares ou através de cursos externos à empresa.

A quarta proposta refere-se ao processamento dos dados, de modo que eles sejam facilmente recuperados pelo usuário que irá tomar a decisão. Inicialmente, o dirigente deve tratar os dados, isto é, registrar, apreciar e consolidar os dados (elaborar sínteses, relatórios etc). Esta proposta é justificada pela existência de dados dispersos que circulam de forma desorganizada nas empresas. Nos dois hotéis que ainda não possuem nenhum tipo de tabela, o registro dos dados podem ser realizados em tabelas criadas no MSAccess ou MSExcel. Pela sua simplicidade, a elaboração das tabelas pode ser na própria empresa ou com a ajuda de algum especialista da área. Outra possibilidade útil e viável a todos os hotéis, incluindo os que já registram alguns dados e querem se aperfeiçoar na utilização da tecnologia é a participação dos dirigentes em cursos ministrados nas escolas de informática ou pela internet, como o curso de gerenciamento de dados realizado pelo Departamento de Engenharia de Produção da Universidade Federal do Rio Grande do Sul, ou ainda a contratação conjunta de um 
profissional que ministre um curso específico para o setor hoteleiro ou crie um programa adequado às necessidades dessas empresas.

Se o dirigente deseja saber a taxa de ocupação do hotel, por exemplo, é necessário criar uma base de dados, contendo registros dos dias da semana, dos tipos de unidades habitacionais (apartamento simples, duplo etc), e dos dias da semana em que essas unidades são ocupadas. Após o registro, apreciam-se os dados e elaboram-se relatórios mensais que demonstrem a quantidade de unidades habitacionais ocupadas e disponíveis durante a semana e mostrem o percentual de ocupação do hotel, ou seja, consolidem os dados interpretados. Este é apenas um exemplo de possíveis combinações de dados que produzem informações úteis ao dirigente do hotel.

As etapas anteriores identificaram os dados e informações que devem ser arquivados e qual a melhor forma de armazená-los para facilitar a sua recuperação pelo usuário da informação. Como nos hotéis de pequeno porte pesquisados a forma predominante escolhida é a própria memória do dirigente, é preciso criar outros mecanismos para ajudar sua memória no arquivo de informações relevantes para a análise estratégica. Os dirigentes podem arquivar as informações na T.I. que está disponível nos próprios hotéis e complementar com as tabelas, relatórios ou formulários - que podem ser manuseados na tela do computador - desenvolvidos na etapa de tratamento dos dados.

A quinta proposta está relacionada à forma de apresentação e escolha do canal de transmissão das informações, isto é, a disseminação das informações. Esta proposta consiste na exibição das informações no formato de relatórios, formulários ou gráficos disponíveis na tela do computador ou impressos em papel. A proposta é uma ação preventiva para evitar a emissão de relatórios com formatação complicada, carente em informações úteis à análise estratégica e sem totalizações (consolidações), como foi diagnosticado na revisão bibliográfica. Como nos hotéis de pequeno porte são os próprios dirigentes que coletam (predominantemente), apreciam e tomam as decisões com base nas informações, existe uma despreocupação com a sua forma de apresentação.

A escolha do canal de transmissão das informações tem mais relevância para o hotel E (médio porte), pois além da gerência geral existe pelo menos mais duas chefias (marketing e recepção) que coletam de forma parcialmente estruturada os dados para subsidiar as decisões do gerente e da diretoria. Essas chefias podem continuar utilizando as conversas informais e as reuniões com a gerência para distribuir as informações que 
devem estar de acordo com as necessidades de informação do tomador de decisão, valendo-se do modo de exibição definido no passo anterior.

Nos hotéis B, C e D (microempresas), os funcionários podem participar da etapa de coleta de dados e transmitir os dados relevantes oralmente, ou por escrito, através das conversas informais ou de reuniões realizadas entre dirigentes e funcionários.

No caso do hotel A (pequeno porte), todos os integrantes da família podem receber os dados dos funcionários sob sua responsabilidade através das conversas informais e reuniões, interpretar esses dados e transmiti-los no modo de exibição definido na etapa de apresentação dos dados, aos demais membros da família que irão tomar a decisão conjuntamente. 


\section{CONSIDERAÇÕES FINAIS}

Este estudo é parte de um conjunto de pesquisas desenvolvidas simultaneamente pelos membros do GEOPE, do Departamento de Engenharia de Produção da EESC/USP, que tem como objetivo realizar estudos, na pequena empresa, relacionados aos temas organizacionais, de forma a entender as suas especificidades e adequar a aplicação de ferramentas gerenciais a essas características típicas. Dentro dessa perspectiva, este trabalho foi desenvolvido com o objetivo de apresentar propostas de melhoria no gerenciamento da informação interna visando à administração estratégica das pequenas empresas.

Esta pesquisa teve início com o levantamento bibliográfico sobre os assuntos relacionados às variáveis de pesquisa: análise interna; informação interna para fins estratégicos, que inclui os tipos e fontes de informação e as metodologias para o gerenciamento estratégico da informação e as especificidades da pequena empresa. Com a revisão da teoria, foi possível elaborar uma síntese da gestão estratégica da informação que guiasse o levantamento do processo utilizado pelos hotéis para gerenciar a informação e que servisse de referência para as possíveis sugestões de melhoria do processo. Esta síntese foi denominada de roteiro de campo e teve um caráter provisório, pois antecedeu as propostas de melhoria.

Os dados coletados e analisados permitem tecer alguns comentários finais sobre as características do processo de gestão estratégica da informação e das especificidades dos hotéis.

Em todos os hotéis pesquisados, existe uma visão de longo prazo, seja por parte do dirigente proprietário ou do gerente e dos meios que irão possibilitar a sua realização. Em dois hotéis, a materialização da visão é mais limitada, principalmente, pela carência de recursos financeiros e nos demais empreendimentos ela é colocada em prática aos poucos e com a utilização de recursos próprios. Como afirmou um dos empresários: "a visão de futuro cresce de acordo com o crescimento da conta bancária". 
Este foco de longo prazo contrariou a tendência do planejamento realizado nessas empresas para focar-se no futuro próximo, ou seja, apenas no curto prazo. Até o hotel que possui um comportamento predominantemente reativo não possui, apenas, foco nas ações de curto prazo.

O processo de formulação da estratégia nos hotéis é informal, até mesmo no de médio porte, conforme diagnosticado na revisão bibliográfica e na pesquisa realizada por Andrade (2003), contrariando uma das premissas básicas da escola do planejamento estratégico de que a estratégia é produto do planejamento formal, constituído de etapas distintas. Esta informalidade é fruto do desconhecimento da ferramenta gerencial ou da própria crença do dirigente que não vê a necessidade de formalização do planejamento devido a sua estrutura simples. Como as decisões estratégicas são tomadas por poucas pessoas (e as vezes até por um único dirigente) que estão próximas umas das outras, facilitando a comunicação verbal, a comunicação por escrito, detalhando as etapas do processo de formulação da estratégia, torna-se desnecessária aos olhos dos dirigentes que irão decidir o rumo do hotel. Além disso, os dirigentes dispõem de pouco tempo e conhecimento para a realização de estudos mais detalhados.

A estratégia normalmente é produto da reflexão individual dos dirigentes, das reuniões familiares ou de conversas informais sobre: a situação financeira e a infraestrutura do hotel; a opinião dos clientes e o movimento da concorrência e os desejos e valores pessoais dos dirigentes. Depois de concebida, a estratégia fica restrita à direção dos empreendimentos, o que não significa dizer que será realizada em sua totalidade. $\mathrm{Na}$ pequena empresa, a não realização do plano concebido pode ocorrer em uma maior freqüência por algumas razões: a carência de informações necessárias ao conhecimento da situação atual da empresa e do comportamento futuro das forças ambientais; o desconhecimento dos dirigentes de uma metodologia para elaborar a estratégia (o plano) e seus benefícios; as limitações de recursos financeiros que inibem a realização dos objetivos e a própria sensibilidade dos hotéis ao comportamento das variáveis ambientais. A própria fala dos dirigentes comprovam as razões apresentadas, por exemplo a do gerente do hotel $\mathrm{E}$, ao afirmar que existe a preocupação com o planejamento estratégico, "mas não existe um plano formal definitivo, que se segue à risca; os objetivos mudam e a formalidade engessa o processo. Outras vezes existe o plano, mas não são colocados em prática por falta de recursos financeiros”, como as ações relacionadas à manutenção do hotel, que comprometem boa parte do faturamento. 
O processo de elaboração torna-se tangível a partir das visões interna e externa ao hotel, embora não se utilize nenhuma metodologia específica. A visão externa é operacionalizada basicamente pelo acompanhamento da opinião dos clientes, das ações da concorrência e da política da prefeitura de forma a identificar aquilo que pode contribuir ou atrapalhar o bom andamento do negócio.

A visão interna se operacionaliza, quando os dirigentes descrevem de forma detalhada os serviços oferecidos pelo hotel ou as deficiências da sua estrutura, identificando as suas forças e fraquezas, quando comparados aos outros empreendimentos hoteleiros. Para realizar a identificação dos pontos fortes e fracos do hotel, os dirigentes analisam os recursos, as habilidades para administrar os recursos e o desempenho da aplicação dos recursos relacionados às atividades de Marketing, Alimentos \& Bebidas, Hospedagem e Administrativa.

As informações sobre preço, custos, competência dos funcionários, opinião dos clientes e financeiras são as mais observadas pelos tomadores de decisão. Com relação às finanças do hotel, os dirigentes afirmam que carecem de mais informações que retratem a capacidade de investimentos da empresa. O diagnóstico dos pontos fortes e fracos se dá por meio das conversas informais entre os dirigentes dos hotéis, das visitas dos dirigentes a outros empreendimentos fora da região, de pesquisas por telefone, na internet e mídias de uma forma geral.

Quanto à disponibilidade de informações para que seja possível realizar a análise interna e externa do hotel, os dirigentes dos hotéis B, C e D dispõem de uma base de dados menos estruturada do que os dirigentes dos hotéis A e E. Quanto menos estruturados estiverem os dados, maior a dificuldade de recuperação das informações na hora da tomada de decisão.

Os hotéis são influenciados pelas forças do macroambiente (economia, tributos, bancos, instituições de ensino e ações do poder público de uma forma geral) e do ambiente operacional (clientes, concorrentes e fornecedores), mas o grau de influência varia de hotel para hotel e está, diretamente, relacionado à capacidade financeira do empreendimento hoteleiro, principalmente na baixa temporada, quando a demanda diminui acentuadamente.

Todos os dirigentes reclamam da inércia da economia, da diminuição da renda e da conseqüente queda da demanda. No entanto, os hotéis que possuem capital próprio para realizar investimentos, realizam os seus objetivos, mesmo que parcialmente. Já os hotéis sem capacidade financeira para colocá-los em prática, permanecem no mesmo 
estado de inércia da economia à espera de momentos melhores. Em relação aos encargos sociais, a opinião é unânime, pesam muito no período da baixa temporada. Quanto aos bancos, são apenas depositários dos recursos financeiros das empresas. Dos cinco hotéis estudados, um não tem uma política de investir apenas com capital próprio. Mesmo este, que já contraiu empréstimo junto a bancos, reclama do limite de crédito e dos juros excessivos cobrados pela instituição. Com relação às instituições de ensino, $o$ dirigente dos hotéis $\mathrm{B}, \mathrm{C}$ e $\mathrm{D}$ questionam a validade da aplicação dos conhecimentos aprendidos pelos estudantes em seus hotéis. As técnicas ensinadas aos estudantes são mais adequadas para hotéis de grande porte.

Quanto às ações do poder público municipal, apenas uma dirigente acredita que a prefeitura cumpre o seu papel de agente fomentador do turismo. A principal queixa é relacionada à falta de uma política municipal de turismo que atraia o turista à cidade. $\mathrm{O}$ ceticismo dos dirigentes em relação às ações da prefeitura é evidente. O Conselho Municipal de Turismo que deveria ser o fórum ideal para discussão do poder público e dos empresários não alcança o seu objetivo de estabelecer políticas que fomentem o setor turístico da cidade de Brotas/SP. Duas razões, entre outras, contribuem para isso: a insatisfação por parte dos empresários em relação à composição do conselho, onde a prefeitura é majoritária e defende os seus interesses e a existência de grupos de empresários dentro do COMTUR, priorizando também as suas reivindicações.

Outro local apropriado para discussão dos interesses do setor turístico seria a Associação Brotas Capital da Aventura. No entanto, a associação tem a finalidade apenas de arrecadar recursos para divulgação da cidade em feiras relacionadas ao turismo. Além disso, nem todos os hoteleiros participam da associação, pois o critério de seleção dos associados é de ordem pessoal, ou seja, ter bom relacionamento com todos os participantes. Cabe ainda ressaltar, que a associação não é uma representação dos hoteleiros que luta pelo desenvolvimento do turismo em Brotas, mas a junção de alguns empresários para ratear custos de propaganda.

Com relação à concorrência, o mercado é competitivo durante a baixa temporada devido à grande oferta de unidades habitacionais e à diminuição acentuada da procura por hospedagem. Mesmo assim o clima de competição entre os hoteleiros não é de rivalidade. Durante a alta temporada e feriados prolongados, a demanda é satisfatória a todos os empreendimentos de pequeno porte. A pesquisa realizada por Andrade (2003) chegou aos mesmos resultados em relação aos hotéis pesquisados em sete cidades da região. 
Os clientes, durante a baixa temporada, negociam os preços da hospedagem, impulsionados pela grande oferta de serviços à sua disposição. É nesse período, também, que ocorre uma grande ociosidade nos hotéis, ocasionando a perecibilidade dos serviços disponíveis e a manutenção da maior parte dos custos fixos (mão-de-obra), principalmente no hotel de médio porte que possui mais funcionários. Surge aqui uma oportunidade para união de hoteleiros e poder público municipal, com o objetivo de estabelecerem, conjuntamente, políticas de apoio ao setor turístico, que consiga atrair os turistas à cidade durante a baixa temporada e diminua a ociosidade nos hotéis. Os fornecedores não limitam e nem são ameaças às ações dos empreendimentos hoteleiros. São em grande número e o mercado é extremamente concorrido entre eles.

As características estruturais mencionadas na revisão bibliográfica manifestaram-se em quase $100 \%$ dos hotéis de pequeno porte. Uma especificidade importante que foi diagnosticada é a preocupação dos dirigentes de quatro hotéis em preencher os cargos com pessoas que possuam os requisitos para ocupá-los. Apenas o hotel B, não demonstrou essa preocupação. As principais características observadas nos hotéis foram: poucas unidades de trabalho (cargos, seções etc), autoridade centralizada, facilidade de controle, entre outras. No hotel de médio porte, algumas especificidades da pequena empresa, também, foram encontradas: poucos níveis hierárquicos, escopo de cargo abrangente da gerência e a existência do contato direto e informal entre gerente, funcionários e hóspedes.

A autoridade é centralizada e as decisões estratégicas são de responsabilidade apenas dos dirigentes. A função diretiva possui muitas atribuições, administrativas e operacionais, limitando o tempo dos dirigentes para aprenderem novas técnicas de administração ou dedicar mais atenção ao pensamento futuro da empresa. A comunicação é, predominantemente, oral nos hotéis de pequeno porte e seu conteúdo é referente à distribuição de tarefas. No hotel A e E, existe também a comunicação por escrito dos procedimentos para realização das tarefas.

A atitude dos dirigentes em relação à aplicação de novas técnicas de administração e a utilização da T.I., nas operações do hotel, é extremamente favorável. Esta atitude está relacionada a duas razões principais: o nível de escolaridade dos dirigentes e o reconhecimento por parte deles da necessidade de aprender conhecimentos e habilidades que os ajudem na administração do hotel. A vontade de aprender, demonstrada por três dirigentes dos hotéis de pequeno porte, durante as 
entrevistas, era evidente. Apenas a proprietária-dirigente de um dos hotéis oferece resistência à aplicação de novas técnicas, embora ela reconheça a necessidade de aprender novos conhecimentos e habilidades.

Quanto aos aspectos tecnológicos, as instalações, equipamentos e processos utilizados nos hotéis, não apresentam a sofisticação dos grandes hotéis, mas também não são obsoletos como foi citado na revisão bibliográfica. Apenas, em um dos hotéis não existe a preocupação em realizar mudanças incrementais na prestação do serviço baseada na tecnologia.

Em relação à T.I., as tecnologias utilizadas visam, predominantemente, realizar e controlar as operações do hotel. Todos os hotéis hospedam a sua página na internet e alguns deles oferecem ao hóspede um canal de comunicação para que faça críticas e sugestões sobre o funcionamento do hotel. Embora a T.I. faça parte do dia-a-dia dos hotéis, os dirigentes dos empreendimentos de pequeno porte ainda não têm consciência da sua utilidade no processo de gestão da informação. No hotel de médio porte a TI já fornece algumas informações úteis ao plano estratégico do hotel, embora ela não tenha sido criada para esta finalidade, mas para efetuar transações dentro do hotel.

Quanto à informação estratégica, os dirigentes reconhecem a importância da informação na gestão do negócio, mas não sabem distinguir, claramente, a diferença entre as informações que são úteis para a realização das operações do dia-a-dia e as informações de natureza estratégica.

De forma desestruturada ou parcialmente estruturada, os hotéis realizam a etapa de coleta de dados para subsidiar as decisões operacionais ou estratégicas dos dirigentes. Entretanto, não existe uma separação clara entre uma e outra na sua mente, com exceção do dirigente do hotel de médio porte que apresentou bastante compreensão do que é uma decisão estratégica.

Além da dificuldade em identificar a real necessidade de informação para pensar o futuro do negócio, os dirigentes dão pouca atenção ao tratamento e armazenamento dos dados. Predominantemente, o registro, a interpretação e o arquivamento de dados ocorrem na mente dos que dirigem o hotel, sendo que no hotel de médio porte acontecem, também, reuniões mensais para discussão desses dados entre chefias e gerência geral. No entanto, nem todos os dados úteis à elaboração do plano estratégico são registrados e armazenados na memória organizacional.

$\mathrm{Na}$ etapa de disseminação, a fase de apresentação das informações é quase inexistente nos hotéis de pequeno porte. Como o tratamento dos dados é realizado pelos 
próprios dirigentes, não há preocupação em consolidar e apresentar esses dados de forma clara, pois eles são os tomadores de decisão. No hotel de médio porte, as informações são transmitidas através das conversas informais e das reuniões entre direção, gerente e chefias.

Mesmo sem a utilização de uma metodologia pré-estabelecida para gerenciar dados e informações, os dirigentes dos hotéis realizam a gestão da informação à sua maneira, produzem informações e incorporam-nas ao processo decisório, quando refletem sobre o futuro do negócio. Por fim cabe destacar, que os hotéis pesquisados apresentam muito mais facilidades do que dificuldades, para realização de um processo estruturado de gestão da informação estratégica.

Dessa forma, a falta de tempo e de conhecimento dos dirigentes, que são dificuldades para melhoria do processo de gerenciamento das informações, podem ser minimizadas pelo desejo de melhorar constantemente o atendimento ao hóspede, pela atitude favorável em utilizar novas técnicas administrativas na gestão do negócio, pela vontade de adquirir novos conhecimentos e habilidades, entre outras facilidades encontradas nos hotéis.

As etapas de coleta, processamento e disseminação de dados e informações poderão ser facilitadas por algumas razões: a primeira razão está relacionada ao uso da T.I. nas atividades operacionais dos hotéis, podendo ser disponibilizada, também, para gerenciar informações de natureza estratégica. A segunda razão refere-se à formalização de alguns procedimentos e à coleta parcialmente estruturada de algumas informações na pequena (hotel A) e na média empresa (hotel E). A terceira razão é inerente apenas à média empresa, que apresenta facilidade para obter informações e possui um sistema de gerenciamento das operações do hotel que fornece relatórios gerenciais.

O processo de gerenciamento estratégico das informações internas nos pequenos hotéis precisa estar vinculado à aplicação de uma metodologia, para que cumpra o seu papel de apoiar as escolhas estratégicas e ajude na consolidação desses hotéis na indústria da hotelaria.

Os dirigentes dos empreendimentos precisam internalizar o conceito de administrar o negócio com base na gestão das informações. As escolhas gerenciais deverão ser subsidiadas pelas informações provenientes do sistema de informações e não em pressentimentos ou intuição.

Os hotéis não precisam selecionar, registrar, apreciar e consolidar todos os dados que estão disponíveis, mas também não podem desperdiçar aqueles dados que podem 
ajudar o dirigente a escolher o melhor caminho para aplicar os recursos escassos da empresa e a monitorar os resultados dessa escolha. Algumas dessas informações estão dentro da própria empresa e não exigirá muitos recursos para a sua gestão.

O dirigente deve voltar sua atenção, principalmente, para as informações que irão possibilitar a avaliação da quantidade e a qualidade dos recursos e suas habilidades para administrá-los, antes da definição da estratégia e durante a sua execução. Especial atenção deve ser dada à definição dos indicadores de desempenho dos aspectos relevantes para o sucesso do negócio, entre eles o atendimento aos hóspedes. Não são medidas de desempenho apenas econômicas, mas principalmente as não econômicas, que são informações simples de serem coletadas, registradas e consolidadas e sinalizam em conjunto com as medidas financeiras, as vantagens e desvantagens competitivas do empreendimento.

No hotel de médio porte (hotel E), as facilidades para o aperfeiçoamento do processo de gestão da informação estratégica são maiores, por isso, é possível a adoção de uma metodologia pré-estabelecida, para realizar as atividades de gerenciamento das informações estratégicas. É uma decisão que depende mais da vontade do gerente do que dos recursos financeiros que limitam parte das ações da empresa. Embora o gerente apresente limitação de tempo para gerenciar o processo e reconheça a necessidade de mais pessoas especializadas na gestão do hotel, a sua experiência de mais de trinta anos em hotelaria, sendo cinco como gerente geral, o conhecimento adquirido durante esses anos e a sua consciência da necessidade de administrar a empresa com base nas informações, possibilita-lhe aperfeiçoar o processo de gerenciamento estratégico da informação.

No hotel de pequeno porte (hotel A), as condições também são favoráveis, mas irá demandar mais recursos financeiros e tempo disponível dos dirigentes para melhorar o processo de gestão das informações. Como os dirigentes têm o desejo de aplicar novas técnicas que lhes ajudem a administrar melhor o hotel e apresentam boa compreensão do negócio e de suas necessidades de informação para tomar decisões, há uma sinalização de que os entraves ao aperfeiçoamento do processo de gerenciamento estratégico da informação poderão ser superados sem muitas dificuldades.

No momento, é mais interessante aos administradores do hotel e aos funcionários, que irão participar do processo, a compreensão do significado da gestão da informação e os benefícios que isto pode trazer para a tomada de decisões estratégicas. 
Quanto às microempresas (hotéis $\mathrm{B}, \mathrm{C}$ e D), classificadas segundo o número de funcionários, elas também apresentam mais facilidades e menos dificuldades para o aperfeiçoamento do processo de gestão da informação, mas numa quantidade menor do que os hotéis A e E. Como no hotel de pequeno porte, os dirigentes das microempresas precisam, inicialmente, conscientizar-se dos benefícios para a administração do hotel resultante do gerenciamento estratégico da informação.

A proposta detalhada do processo de gerenciamento estratégico das informações internas que os hotéis podem utilizar foi descrita na seção 5.3 do capítulo cinco. De uma maneira geral todos os hotéis precisam aperfeiçoar as etapas propostas para o gerenciamento estratégico da informação de acordo com as suas especificidades e necessidades mais prementes. Para melhoria do processo de gestão da informação nos hotéis, foram apresentadas cinco propostas: a primeira proposta é a conscientização dos dirigentes da relevância do processo de gerenciamento da informação; a segunda proposta é a identificação das informações estratégicas a partir da compreensão do funcionamento do hotel; a terceira proposta é o aperfeiçoamento dos instrumentos de coleta de dados, através da captação de dados relativos às áreas essenciais para realização dos objetivos do hotel; a quarta proposta está relacionada ao registro, apreciação e consolidação dos dados que estão dispersos e circulando, de forma desorganizada, na empresa e relacionada à ampliação da memória organizacional do hotel; a quinta proposta diz respeito a exibição das informações no formato de relatórios, formulários ou gráficos na tela do computador ou impressos em geral.

A pesquisa desenvolvida apresenta algumas limitações. Como primeira limitação, tem-se a amplitude restrita das informações estratégicas, limitando-se apenas às informações úteis à análise dos aspectos internos da empresa. Cabe ressaltar que outra integrante do GEOPE está estudando o mesmo tema com ênfase nas informações úteis à análise do ambiente dos pequenos hotéis. A segunda limitação está na seleção das empresas pelo número de unidades habitacionais que maquiou a heterogeneidade dos hotéis.

Para trabalhos futuros, no tema de gestão da informação, poderão ser realizadas pesquisas visando identificar quais os tipos e fontes de informações que realmente são imprescindíveis à gestão dos pequenos hotéis, como também, procurar compreender a relação entre as informações operacionais e estratégicas. Outra proposta de pesquisa é o estudo dos temas organizacionais (estratégia, comportamento, estrutura, decisão e 
tecnologia), com o objetivo de compreender as especificidades do funcionamento da pequena empresa e elaborar técnicas adequadas a sua gestão. 


\section{REFERÊNCIA BIBLIOGRÁFICA}

ALMEIDA, M. I. R. de (2001). Manual de planejamento estratégico: desenvolvimento de um plano estratégico com a utilização de planilhas excel. São Paulo: Atlas.

ANDRADE, J. H. de (2003). Gestão da informação do ambiente externo na pequena empresa. Relatório Técnico Parcial de Iniciação Científica - EESC-USP, São Carlos.

ANFOFF, H. I.; McDONELL, E. J. (1993). Implantando a administração estratégica. $2^{a}$ ed. - São Paulo: Atlas.

ASHKENAS, Ron (1997). A roupa nova da organização. In: HESSELBEIN, Frances; GOLDSMITH, Marshall; BECKHARD, Richard (ed.). A organização do futuro: como preparar hoje as empresas de amanhã. The Peter F. Drucker Foundation (org.). São Paulo: Futura, 1997.

BATEMAN, T. S.; SNELL, S. A. (1998). Administração: construindo vantagem competitiva. São Paulo: Atlas.

BENI, M. C. (1998). Mesa-redonda: Gestão de turismo no Brasil. In: Revista de Administração da USP (RAUSP), São Paulo: FEA/USP, Departamento de Administração, v.33, n.4, p.5-25, outubro/dezembro.

BENI, M. C. (1998). Análise estrutural do turismo. - 2.ed. - São Paulo: Editora Senac.

BETHLEM, A. de S. (2002). Estratégia empresarial: conceitos, processo e administração estratégica. - 4.ed. - São Paulo: Atlas.

BEUREN, I. M.(2000). Gerenciamento da informação: um recurso estratégico no processo de gestão empresarial. - 2 ed. - São Paulo: Atlas.

BEUREN, I. M.; MARTINS, Luciano W. (2001). Sistema de informações executivas: suas características e reflexões sobre sua aplicação no processo de gestão. Revista Contabilidade \& finanças, São Paulo: FIPECAFI, FEA-USP, v.15, n.26, p.6-24, maio/agosto.

BOONE, L. E.; KURTZ, D. L. (1998). Marketing contemporâneo. - 8.ed - Rio de Janeiro: LTC.

BORTOLI NETO, A. de (1980). Tipologia de problemas das pequenas e médias empresas. Dissertação de mestrado, FEA/USP, São Paulo.

CAMPOS FILHO, M. P. (1994). Os sistemas de informação e as modernas tendências da tecnologia e dos negócios. Revista de Administração de Empresas (RAE/FGV), São Paulo, v.34, n.6, p.33-45, novembro/dezembro. 
CARVAlHO, C. L. (1998). Desenvolvimento do turismo no Brasil. Revista de Administração da USP (RAUSP), São Paulo: FEA/USP, Departamento de Administração, v.33, n.4, p.26-29, outubro/dezembro.

CASSARO, A. C. (2001). Sistemas de informações para tomada de decisões. - 3ed. São Paulo: Pioneira/Thomson Learning.

CAVAlCANTI, M.; FARAH, O. E.; MELlO, A. A. A. (1981). Diagnóstico organizacional: uma metodologia para pequenas e médias empresas. São Paulo: Ed. Loyola.

CERTO, S. S.; PETER, J. P. (1993). Administração estratégica: planejamento e implantação de estratégia. São Paulo: Makron Books.

CHICHINELLI, M.; CAZARINI, E. (1998). Integrando os requisitos não funcionais ao processo de desenvolvimento de sistemas de informação. In: XXII Encontro Nacional de Engenharia de Produção. Anais, Curitiba/PR.

COSTA, B. K. (1999). Análise estratégica na gestão de empresas hoteleiras: proposição de um modelo. Tese (doutorado) - Faculdade de Economia, Administração e Contabilidade, Universidade de São Paulo, São Paulo, 1999.

DALFOVO, O. ; RODRIGUES, L. C. (1998). Delineamento de um sistema de informação estratégico para tomada de decisão nas pequenas e médias empresas do setor têxtil de Blumenau. Revista de Negócios, Blumenau: Centro de Ciências Sociais Aplicadas da FURB, v.3, n.3, p.43-56, julho/setembro.

DUARTE, V. V. (1996). Administração de sistemas hoteleiros: conceitos básicos. São Paulo: Editora SENAC.

ECCLES, R. G. (2000). Manifesto da mensuração do desempenho. In: Medindo o desempenho empresarial. Harvard Business Review. Rio de Janeiro: Campus.

ESCRIVÃO FILHO, Edmundo (1998). Fundamentos de Administração. In: ESCRIVÃO FILHO, Edmundo (ed.). Gerenciamento na construção civil. São Carlos: EESC/USP.

FISCHMANN, A. A.; ALMEIDA, M. I. R. (1991). Planejamento estratégico na prática. - 2.ed. - São Paulo: Atlas.

FISCHMANN, A. A.; ZILBER, M. A. (1999). Utilização de indicadores de desempenho como instrumento de suporte à gestão estratégica. In: ENANPAD, 23, 1998, Foz do Iguaçu. Resumos. Rio de Janeiro: ANPAD, 1999, cd-rom, p.173.

FREIRE, A. (1997). Estratégia: Sucesso em Portugal. Lisboa: Verbo.

FURLAN, J. D.; IVO, I. da M.; AMARAL, F. P. (1994). Sistema de informação executiva $=$ EIS-Executive Information System: como integrar os executivos ao sistema informacional das empresas, fornecendo informações úteis e objetivas para suas necessidades estratégicas e operacionais. São Paulo: Makron Books. 
GIANESI, I. G. N.; CORRÊA, H. L. (1996). Administração estratégica de serviços: operações para a satisfação do cliente. São Paulo: Atlas.

GIMENEZ, F. A. P. (1988). Comportamento estratégico dos dirigentes de pequenas empresas moveleiras de Londrina - Paraná. Dissertação de mestrado, FEA/USP, São Paulo.

GOLDE, R. A. (1986). Planejamento prático para pequenas empresas. In: Coleção Harvard de Administração. São Paulo: Nova Cultural, v.9, p.7-34.

HAMPTON, D. R. (1992). Administração contemporânea: teoria, prática e casos. 3.ed. - São Paulo: McGraw-Hill.

HAYASHI, C. H.; NAKAMURA, M. M.; ESCRIVÃO FILHO, E. (1995). Estratégia empresarial e a pequena empresa. In: VIII Congresso Latino-Americano de Estratégia. Anais, São Leopoldo, Rio Grande do Sul/RS.

HITT, M. A.; IRELAND R. D.; HOSKISSON, R. E. (2002). Administração estratégica. São Paulo: Pioneira Thomson Learning.

KATZ, R. L. (1986). As habilitações de um administrador eficiente. In: Coleção Harvard de Administração. São Paulo: Nova Cultural, p.57-93.

KOTLER, P. (1998). Administração de Marketing: análise, planejamento, implementação e controle. - 5ed. - São Paulo: Atlas.

KOTLER, P. ; ARMSTRONG, G. (1998). Princípios de marketing. - $7^{\mathrm{a}}$ ed. - Rio de Janeiro: Prentice-Hall do Brasil.

KWASNICKA, E. L. (1995). Introdução à Administração. $5^{\mathrm{a} e d . ~ S a ̃ o ~ P a u l o: ~ A t l a s . ~}$

LEAVITT (1978). Mudança organizacional. In: LOBES, Júlio A. Comportamento organizacional: leituras selecionadas. São Paulo: Atlas.

LEONE, N. M. de C. P. G. (1991). A dimensão física das pequenas e médias empresas (P.M.E'S): à procura de um critério homogeneizador. Revista de Administração de Empresas (RAE/FGV), São Paulo: EAESP/FGV, v.31, n², p.53-59, Abril/Junho.

LEONE, N. M. de C. P. G. (1999). As especificidades das pequenas e médias empresas. Revista de Administração (RAUSP), São Paulo: FEA/USP, Departamento de Administração, v.34, n², p.91-94, Abril/Junho.

LESCA, H.; ALMEIDA, F. C. (1994). Administração estratégica da informação. Revista de Administração da USP(RAUSP), São Paulo: FEA/USP, Departamento de Administração, v.29, n.3, p.66-75, julho/setembro.

LUDKE, M.; ANDRÉ, M. D. A. (1986). Pesquisa em educação: abordagens qualitativas. São Paulo: EPU. 
MATIAS, ${ }^{a}$ B.; LOPES Jr., F. (2002). Administração financeira nas empresas de pequeno porte. São Paulo: Manole.

MATTAR, F. N. (1996). Pesquisa de Marketing. Edição compacta. São Paulo: Atlas. McGEE , J. V., PRUSAK, L. (1994). Gerenciamento estratégico da informação. Rio de Janeiro: Campus.

McGREGOR, D. (1980). Os aspectos humanos da empresa. São Paulo: Martins Fontes.

MAXIMIANO, A. C. A. (2000a). Teoria geral da administração: da escola científica à Competitividade na economia globalizada. - $2^{\mathrm{a} e d .}$ - São Paulo: Atlas.

MAXIMIANO, A. C. A. (2000b). Introdução à administração. - 5aed. - São Paulo: Atlas.

MINOZZI, W. S. (1987). A pequena e média empresa e o seu empresário. Dissertação de mestrado, PUC/SP, São Paulo.

MINTZBERG, H.; AHLSTRAND, B.; LAMPEL, J. (2000). Safári de estratégia. Porto Alegre: Bookman.

MORAIS, E. F. C. (Coord.) (1999). Inteligência competitiva: estratégias para pequenas empresas. Brasília: GH comunicação Gráfica Ltda.

NADLER, David A.; TUSHMAN, Michael L. (1994). Projetos de organização com boa adequação: uma moldura para compreender as novas organizações. In: NADLER, D. A.; GERSTEIN, M.S.; SHAW, R.B. \& ASSOCIADOS. Arquitetura organizacional. Rio de Janeiro: Campus.

OLIVEIRA, D. de P. R. de (2001). Estratégia empresarial \& vantagem competitiva: como estabelecer, implementar e avaliar. - 3ed. - São Paulo: Atlas.

OLIVEIRA, D. de P. R. de (2002a). Planejamento estratégico: conceitos, metodologia e práticas. - 18ed. - São Paulo: Atlas.

OLIVEIRA, D. de P. R. de (2002b). Sistemas de informações gerenciais: estratégicas, táticas e operacionais. - 8ed. - São Paulo: Atlas.

PINHEIRO, M. (1996). Gestão e desempenho das empresas de pequeno porte. Tese de doutorado, FEA/USP, São Paulo.

PORTAL TURÍSTICO: MUNICÍPIOS PAULISTAS (2003). Disponível em: http:// www.turismopaulista.sp.gov.br (julho de 2003)

POZZEBON, M.; FREITAS, H. M. R. de (1996). Construindo um EIS (enterprise information system) da (e para a) empresa. Revista de Administração da USP (RAUSP), São Paulo: FEA/USP, Departamento de Administração, v.31, n.4, p.19-30, outubro/dezembro. 
RAMIRO, D., LOTURCO, R. (2002). O poder das pequenas. Revista Veja, n.45, p.1289, novembro.

ROBBINS, S.; COULTER, M. (1998). Administração. 5.ed. - Rio de Janeiro: PrenticeHall do Brasil.

ROCKART, J. F. (1979). Chief executives define their own needs. Harvard Business Review, v., n., p.81-93, march/april.

RUAS, R. L.; PINHEIRO, I. A. (1996). Sua empresa é competitiva? Diagnóstico de competitividade para as micro e pequenas empresas comerciais. Brasília: Ed: SEBRAE.

SEBRAE - SP/FIPE (1999). A questão do financiamento nas MPEs do Estado de São Paulo. http:/ www.sebraesp.org.br (julho/2003).

SEBRAE - SP (2000a). Onde estão as MPEs paulistas. http:/www.sebraesp.org.br (julho/2003).

SEBRAE - SP (2000b). Diagnóstico municipal: Município de Brotas. http:/ www.sebraesp.org.br.julho/2003).

SEBRAE - SP (2001). Diagnóstico municipal: Município de Águas de São Pedro. http:/ www.sebraesp.org.br.julho/2003).

SILVA, E. L. da; MENEZES, E. M. (2000). Metodologia da pesquisa e elaboração de dissertação. Florianópolis, Laboratório de Ensino à Distância da UFSC. http://www.eps.ufsc.br/ppgep.html (agosto/2003).

SOUZA, M. C. A. F. (1995). Pequenas e médias empresas na reestruturação industrial. Brasília: Ed. SEBRAE.

STAIR, R. M. (1998). Princípios de sistemas de informação: uma abordagem gerencial. - 2.ed. - Rio de Janeiro: LTC.

TERENCE, A. C. F.; (2002). Planejamento estratégico como ferramenta de competitividade na pequena empresa: desenvolvimento e avaliação de um roteiro prático para o processo de elaboração do planejamento. Dissertação de mestrado, EESC/USP, São Carlos.

THOMPSON Jr., A. A.; STRICKLAND III, A. J. (2000). Planejamento estratégico: elaboração, implementação e execução. São Paulo: Pioneira.

TRIVIÑOS, A. N. S. (1992). Introdução à pesquisa em Ciências Sociais: a pesquisa qualitativa em educação. São Paulo: Atlas.

VASCONCELLOS FILHO, P. de (1982). Afinal, o que é planejamento estratégico? In: VASCONCELLOS FILHO, P. de; MACHADO, A. de M. V. (1982). Planejamento estratégico: formulação, implementação e controle. Rio de Janeiro: LTC; Belo Horizonte: Fundação João Pinheiro. 
VASCONCELLOS FILHO, P. (1983) Planejamento e controle: uma proposição brasileira. Rio de Janeiro. LTC.

YÁZIGI, E. (2000). A pequena hotelaria e o entorno municipal: guia de montagem e administração. São Paulo: Contexto. 


\title{
APÊNDICES
}

\section{APÊNDICE A - Caracterização das empresas}

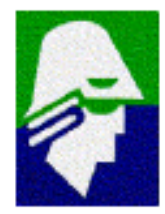

\author{
UNIVERSIDADE DE SÃO PAULO \\ ESCOLA DE ENGENHARIA DE SÃO CARLOS \\ ENGENHARIA DE PRODUÇÃO
}

\section{Etapa 1 - Identificação da Empresa}

1.1 Razão Social:

1.2 Nome Fantasia:

1.3 Ano de Fundação da Empresa:

1.4 Número de Funcionários:

1.5 Número de quartos ou apartamentos:

1.6 Classificação quanto ao número de estrelas (de 1 a 5):

1.7 A Empresa possui quantos Proprietários?

Caso tenha mais de um, qual a porcentagem de participação de cada?

\section{Etapa 2 - Identificação do Dirigente da Empresa}

2.1 Nome:

2.2 É o proprietário da Empresa? $\square$ Sim $\square$ Não.

Função na empresa:

2.3 Possui outro tipo de atividade remunerada, além da Empresa? $\square$ Sim $\square$ Não

2.4 Qual foi a motivação para abertura da Empresa?

$\square$ Oportunidade de Negócio $\square$ Já era da família $\square$ Saída do Emprego 
$\square$ Outra (especificar):

2.5 Qual seu nível de escolaridade?
$1^{\circ} \mathrm{Grau}$
$\square 2^{\circ} \mathrm{Grau}$
$\square$ Formação Técnica
Curso Superior

$\square$ Outro(especificar):

2.6 Possuía algum tipo experiência anterior em hotelaria? $\square$ Não $\square$ Sim.

Se Sim. Em qual função?:

Quanto tempo de experiência total? anos

\section{Etapa 3 - Estrutura da Empresa}

[Nas perguntas 3.1 e 3.3 marque mais de uma alternativa, caso seja necessário]

3.1 Quais tipos de quarto ou apartamento sua empresa oferece?

$\square$ Simples $\square$ Duplo $\square$ Luxo $\square$ Outro:

3.2 Quais são os valores das diárias praticadas em seu Hotel ou Pousada?

Menor Valor: R\$

Maior Valor: R\$

3.3 Marque as opções de acordo com o que a Empresa oferece para os clientes:

$\square$ Restaurante $\square$ Piscina $\square$ Lavanderia $\square$ Garagem/Estacionamento

$\square$ Área de Lazer $\quad \square$ Salão de Eventos

Outros:

3.4 Alguns serviços fornecidos pela empresa são terceirizados?

$\square$ Não $\square$ Sim: Quais?

3.5 Além do(s) proprietário(s), existem pessoas no comando de outros funcionários na Empresa? Por exemplo, supervisores ou gerentes? $\square$ Sim $\square$ Não

Se Sim. Especificar: 


\section{Etapa 4 - Sobre os Concorrentes da Empresa}

4.1 Quantos são os principais concorrentes?

4.2 De onde são? [Marque mais de uma alternativa, caso seja necessário]
Locais $\square$ Regionais

4.3 Os concorrentes oferecem:

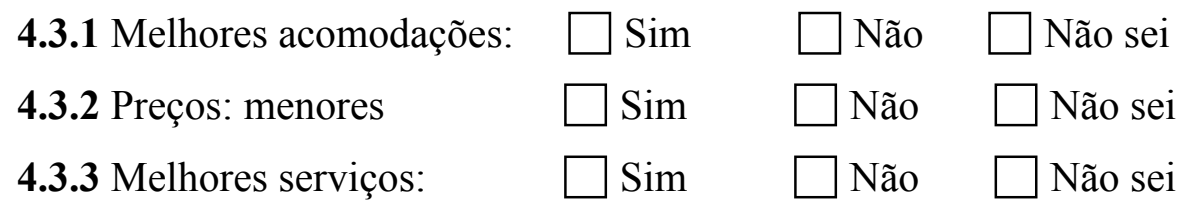

4.3.4 Outro (especificar):

Etapa 5 - Sobre os Clientes da Empresa

[Nas perguntas a seguir marque mais de uma alternativa, caso seja necessário]

5.1 Qual a idade dos principais clientes?

$\square 15$ a $35 \quad \square 36$ a $60 \quad \square 60$ ou mais

5.2 Os principais clientes da Empresa buscam atividades de:
Lazer/Culturais
Negócios
Aventura
Saúde

5.3 De onde são os principais clientes da Empresa?

$\square$ Da Região

$\square$ Capital - Grande São Paulo

$\square$ De todo o Estado

De outros Estados

$\square$ Outras Localidades:

5.4 Em qual período do ano a Empresa tem mais movimento de clientes?

$\square$ Dezembro/Janeiro $\square$ Fevereiro $\square$ Julho $\square$ Outros meses:

5.5 Qual a taxa de ocupação média de $2^{\mathrm{a}}$ a $6^{\mathrm{a}}$ feira?

5.6 Qual a taxa de ocupação média nos finais de semana? 
Etapa 6 - Quanto aos Fornecedores da Empresa

Utilize os número de 1 a 5 abaixo para responder a questão 6.1.

1-Diariamente 2-Semanalmente 3-Mensalmente 4-Anualmente 5-Nunca

6.1 Com que freqüência você negocia com os seguintes tipos de fornecedores?

Fornecedores de Alimentos

Fornecedores de Bebidas

Fornecedores de Móveis

Fornecedores de "Cama, Mesa e Banho"

6.2 De onde são os principais fornecedores? [Marque mais de uma alternativa, caso seja necessário]

$\square$ Locais $\square$ Regionais $\square$ Do Estado $\square$ De outros Estados $\square$ Do Exterior

\section{Etapa 7 - Cooperação entre Empresas}

7.1 Você considera importante a cooperação entre empresas hoteleiras da cidade e região?

$\square \operatorname{Sim} \square$ Não

7.2 Você estaria disposto a conversar com outros empresários hoteleiros da cidade e região para empreendimentos conjuntos?

$\square \operatorname{Sim} \quad \square$ Não

7.3 A Prefeitura tem ajudado o desenvolvimento do turismo na Cidade?

$\square \operatorname{Sim} \square$ Não

Espaço reservado para comentários / sugestões 


\title{
APÊNDICE B - Temas específicos de pesquisa
}

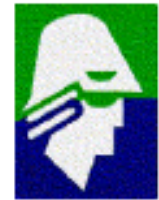

\author{
UNIVERSIDADE DE SÃO PAULO \\ ESCOLA DE ENGENHARIA DE SÃO CARLOS \\ ENGENHARIA DE PRODUÇÃO
}

\section{QUESTIONÁRIO DE PESQUISA}

Em primeiro lugar, agradecemos sua participação e interesse pela pesquisa e apreciamos o tempo que dedicou ao preenchimento do primeiro questionário. Salientamos que sua colaboração é imprescindível para o sucesso desta pesquisa.

Lembramos que os resultados agregados da pesquisa (somente os agregados e jamais as informações individuais) serão divulgados entre os participantes, na expectativa de que poderão contribuir com o gerenciamento de suas empresas.

Estamos enviando, agora, o segundo e último questionário relacionado a esta pesquisa. Este questionário tem como objetivo obter informações sobre pontos específicos relacionados ao processo de gestão de sua empresa.

Solicitamos que este questionário seja respondido pelo dirigente, ou seja, aquela pessoa responsável pelas decisões sobre os rumos a serem seguidos pela empresa.

Nossos agradecimentos e em breve entraremos em contato para fornecer os resultados.

Cordialmente,

Prof. Dr. Edmundo Escrivão Filho Coordenador do GE-PEPE 
FMPRFSA:

SECÃ̃ 1 - Planejamento Estratégico

"Planejamento estratégico é uma técnica administrativa que procura ordenar as idéias das pessoas, de forma que se possa criar uma visão do caminho que se deve seguir (estratégia). Em seguida são ordenadas as ações, que é a implementação do plano estratégico, para que, sem desperdício de esforços, caminhe na direção pretendida.” (Almeida, 2001,p.13)

1 Existe na empresa uma preocupação em se desenvolver o planejamento estratégico?

$\square \operatorname{Sim} \quad \square$ Não

Caso tenha respondido SIM, prossiga respondendo a questão 1.1. Se respondeu NÃO, avance para a questão 2 .

1.1 São realizadas reuniões na empresa para se discutir o planejamento estratégico?

$\square \operatorname{Sim} \quad \square$ Não

1.2 Os planos e decisões do planejamento são descritos em um documento?

$\square \operatorname{Sim} \quad \square$ Não

1.3 Os planos e decisões do planejamento são divulgados na empresa?

$\square \operatorname{Sim} \quad \square$ Não

2 Você considera o mercado em que sua empresa atua:

$\square$ Muito competitivo $\square$ Competitivo $\square$ Pouco competitivo

3 Você sente que a maior parte de seu tempo na empresa é utilizado para:

$\square$ Prevenir a empresa de futuros problemas

$\square$ Solucionar problemas já existentes

4 Você sente que utiliza muito do seu tempo solucionando problemas simples, rotineiros e repetitivos?

$\square \operatorname{Sim} \quad \square$ Não

5 Você acha que alguns dos problemas maiores que a empresa enfrenta hoje poderiam ter sido evitados?

$\square \operatorname{Sim} \quad \square$ Não

6 Você considera importante a participação dos funcionários na identificação e solução dos problemas da empresa?

$\square \operatorname{Sim} \quad \square$ Não 


\section{SEÇ̃̃O 2 - Gestão Estratégica da Informação}

1 Qual a importância dos tipos de informações externas para a gestão de sua empresa?

\begin{tabular}{|c|c|c|c|c|c|}
\hline Tipos de Informação & \begin{tabular}{|l|} 
Muito \\
Importante
\end{tabular} & Importante & $\begin{array}{l}\text { Média } \\
\text { Importância }\end{array}$ & $\begin{array}{l}\text { Pouco } \\
\text { Importante }\end{array}$ & $\begin{array}{l}\text { Sem } \\
\text { Importância }\end{array}$ \\
\hline Econômicas & $\square$ & $\square$ & $\square$ & $\square$ & $\square$ \\
\hline Sociais e Demográficas & $\square$ & $\square$ & $\square$ & $\square$ & $\square$ \\
\hline Legais & $\square$ & $\square$ & $\square$ & $\square$ & $\square$ \\
\hline Políticas & $\square$ & $\square$ & $\square$ & $\square$ & $\square$ \\
\hline Culturais & $\square$ & $\square$ & $\square$ & $\square$ & $\square$ \\
\hline Tecnológicas & $\square$ & $\square$ & $\square$ & $\square$ & $\square$ \\
\hline Internacionais & $\square$ & $\square$ & $\square$ & $\square$ & $\square$ \\
\hline Ecológicas & $\square$ & $\square$ & $\square$ & $\square$ & $\square$ \\
\hline Concorrência & $\square$ & $\square$ & $\square$ & $\square$ & $\square$ \\
\hline Clientes & $\square$ & $\square$ & $\square$ & $\square$ & $\square$ \\
\hline Fornecedores & $\square$ & $\square$ & $\square$ & $\square$ & $\square$ \\
\hline
\end{tabular}

2 Qual a importância dos tipos de informações internas para a gestão de sua empresa?

\begin{tabular}{|l|c|c|c|l|l|}
\hline \multicolumn{1}{|c|}{ Tipos de Informação } & $\begin{array}{l}\text { Muito } \\
\text { Importante }\end{array}$ & Importante & $\begin{array}{l}\text { Média } \\
\text { Importância }\end{array}$ & $\begin{array}{l}\text { Pouco } \\
\text { Importante }\end{array}$ & $\begin{array}{l}\text { Sem } \\
\text { Importância }\end{array}$ \\
\hline Comercial & $\square$ & $\square$ & $\square$ & $\square$ & $\square$ \\
\hline Hospedagem & $\square$ & $\square$ & $\square$ & $\square$ & $\square$ \\
\hline Alimentos e Bebidas & $\square$ & $\square$ & $\square$ & $\square$ & $\square$ \\
\hline Finanças & $\square$ & $\square$ & $\square$ & $\square$ & $\square$ \\
\hline Recursos Humanos & $\square$ & $\square$ & $\square$ & $\square$ & $\square$ \\
\hline Manutenção & $\square$ & $\square$ & $\square$ & $\square$ & $\square$ \\
\hline
\end{tabular}

3 Existe na empresa um acompanhamento regular sobre as informações externas e internas consideradas Importantes e Muito Importantes?

Se sim, como é realizada?

Se não, comente por quê? 
4 Quais são as maiores dificuldades encontradas para se obter estas informações?

5 Com que freqüência os fatores abaixo relacionados são utilizados por você para direcionar suas ações na administração de sua empresa?

\begin{tabular}{|c|c|c|c|}
\hline Fatores & Muito utilizado & Utilizado & Pouco utilizado \\
\hline Informação & $\square$ & $\square$ & $\square$ \\
\hline Intuição & $\square$ & $\square$ & $\square$ \\
\hline Experiência & $\square$ & $\square$ & $\square$ \\
\hline
\end{tabular}

6 Qual a importância das fontes de informação para a gestão de sua empresa?

\begin{tabular}{|l|c|c|c|c|c|}
\hline \multicolumn{1}{|c|}{ Fontes de Informação } & $\begin{array}{l}\text { Muito } \\
\text { Importante }\end{array}$ & Importante & $\begin{array}{l}\text { Média } \\
\text { Importância }\end{array}$ & $\begin{array}{l}\text { Pouco } \\
\text { Importante }\end{array}$ & $\begin{array}{l}\text { Sem } \\
\text { Importância }\end{array}$ \\
\hline $\begin{array}{l}\text { Jornais e Revistas em } \\
\text { geral }\end{array}$ & $\square$ & $\square$ & $\square$ & $\square$ & $\square$ \\
\hline $\begin{array}{l}\text { Revistas ou Livros } \\
\text { Especializados }\end{array}$ & $\square$ & $\square$ & $\square$ & $\square$ & $\square$ \\
\hline Fornecedores & $\square$ & $\square$ & $\square$ & $\square$ & $\square$ \\
\hline $\begin{array}{l}\text { Visita a Empresas } \\
\text { Concorrentes }\end{array}$ & $\square$ & $\square$ & $\square$ & $\square$ & $\square$ \\
\hline $\begin{array}{l}\text { Ex-Empregados de } \\
\text { Concorrentes }\end{array}$ & $\square$ & $\square$ & $\square$ & $\square$ & $\square$ \\
\hline $\begin{array}{l}\text { Colegas mais } \\
\text { experientes }\end{array}$ & $\square$ & $\square$ & $\square$ & $\square$ & $\square$ \\
\hline $\begin{array}{l}\text { Funcionários da } \\
\text { Empresa }\end{array}$ & $\square$ & $\square$ & $\square$ & $\square$ & $\square$ \\
\hline $\begin{array}{l}\text { Consultores de } \\
\text { Empresas }\end{array}$ & $\square$ & $\square$ & $\square$ & $\square$ & $\square$ \\
\hline $\begin{array}{l}\text { Professores } \\
\text { Universitários }\end{array}$ & $\square$ & $\square$ & $\square$ & $\square$ & $\square$ \\
\hline
\end{tabular}




\begin{tabular}{|l|c|c|c|c|c|}
\hline Clientes da Empresa & $\square$ & $\square$ & $\square$ & $\square$ & $\square$ \\
\hline Agências de Viagem & $\square$ & $\square$ & $\square$ & $\square$ & $\square$ \\
\hline $\begin{array}{l}\text { Seminários, Cursos e } \\
\text { Congressos }\end{array}$ & $\square$ & $\square$ & $\square$ & $\square$ & $\square$ \\
\hline Gerentes de Bancos & $\square$ & $\square$ & $\square$ & $\square$ & $\square$ \\
\hline Publicações Cientificas & $\square$ & $\square$ & $\square$ & $\square$ & $\square$ \\
\hline SEBRAE & $\square$ & $\square$ & $\square$ & $\square$ & $\square$ \\
\hline Viagens & $\square$ & $\square$ & $\square$ & $\square$ & $\square$ \\
\hline Associações Comerciais & $\square$ & $\square$ & $\square$ & $\square$ & $\square$ \\
\hline Televisão e Internet & $\square$ & $\square$ & $\square$ & $\square$ & $\square$ \\
\hline Contador da Empresa & $\square$ & $\square$ & $\square$ & $\square$ & $\square$ \\
\hline $\begin{array}{l}\text { Balanço Financeiro da } \\
\text { Empresa }\end{array}$ & $\square$ & $\square$ & $\square$ & $\square$ & $\square$ \\
\hline Equipe de Vendas & $\square$ & $\square$ & $\square$ & $\square$ & $\square$ \\
\hline Outras, especificar: & $\square$ & & $\square$ & $\square$ \\
\hline
\end{tabular}

\section{SEÇÃO 3 - Aspectos de Organização da Empresa}

1 Classifique em ordem de importância os seguintes fatores que podem ser utilizados como critérios para a contratação:

\begin{tabular}{|l|c|c|c|c|c|}
\hline Critérios & $\begin{array}{l}\text { Muito } \\
\text { Importante }\end{array}$ & Importante & $\begin{array}{l}\text { Média } \\
\text { Importância }\end{array}$ & $\begin{array}{l}\text { Pouco } \\
\text { Importante }\end{array}$ & $\begin{array}{l}\text { Sem } \\
\text { Importância }\end{array}$ \\
\hline $\begin{array}{l}\text { Grau de } \\
\text { escolaridade }\end{array}$ & $\square$ & $\square$ & $\square$ & $\square$ & $\square$ \\
\hline $\begin{array}{l}\text { Cursos } \\
\text { específicos de } \\
\text { hotelaria }\end{array}$ & $\square$ & $\square$ & $\square$ & $\square$ & $\square$ \\
\hline $\begin{array}{l}\text { Experiência } \\
\text { anterior em } \\
\text { empresas }\end{array}$ & $\square$ & $\square$ & $\square$ & $\square$ & $\square$ \\
\hline
\end{tabular}




\begin{tabular}{|l|c|c|c|c|c|}
\hline diversas & & & & & \\
\hline $\begin{array}{l}\text { Experiência } \\
\text { anterior em } \\
\text { hotéis }\end{array}$ & $\square$ & $\square$ & $\square$ & $\square$ & $\square$ \\
\hline $\begin{array}{l}\text { Indicação de } \\
\text { parentes, } \\
\text { amigos ou } \\
\text { funcionários }\end{array}$ & $\square$ & $\square$ & $\square$ & $\square$ & $\square$ \\
\hline
\end{tabular}

2 Identifique dois cargos considerados importantes para o hotel.

1 -

$2-$

3 Assinale a alternativa que melhor representa seu estilo de administrar:

$\square$ Faço questão de me manter informado sobre tudo o que acontece na empresa. Nenhuma decisão é tomada sem o meu consentimento.

$\square$ Faço questão de me manter informado sobre tudo o que acontece na empresa, mas sempre conto com a opinião de alguns funcionários antes de tomar uma decisão.

Tomo as principais decisões do hotel, mas as decisões referentes a assuntos do diaa-dia e a problemas mais corriqueiros podem ser tomadas por funcionários sem minha intervenção.

4 Analisando suas responsabilidades atuais como dirigente, caso fosse preciso afastar-se devido a alguma emergência, o você acredita que o conhecimento dos funcionários sobre o funcionamento do hotel seria suficiente para administrá-lo em sua ausência?

$\square \operatorname{Sim} \quad \square$ Não

Por quê? 
5 Como um funcionário que acaba de ser contratado toma conhecimento do trabalho que ficará sob sua responsabilidade? 


\title{
APÊNDICE C - Roteiro de entrevista
}

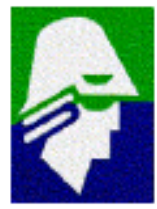

\author{
UNIVERSIDADE DE SÃO PAULO \\ ESCOLA DE ENGENHARIA DE SÃO CARLOS \\ ENGENHARIA DE PRODUÇÃO
}

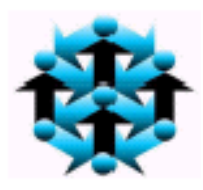

PESQUISA DE CAMPO

A. Especificidades Ambientais - Caracterização do ambiente que envolve a empresa 01 Quais as forças do ambiente (variáveis) mais importantes que limitaram as ações da empresa nos últimos dois anos?

$\square$ Instituições governamentais

$\square$ Os grandes hotéis

$\square$ Instituições de ensino

$\square$ Fornecedores

$\square$ Clientes

$\square$ Política econômica

Instituições de crédito

$\square$ Política tributária

$\square$ Política fiscal Outras:

02 De acordo com os itens marcados na questão anterior quais foram as principais restrições impostas à empresa?

\section{B. Especificidades estruturais - Caracterização da estrutura da empresa}

03 A empresa é dotada de setores específicos para os processos organizacionais abaixo:

Sim Não

Comercial

Hospedagem

Alimentos \& bebidas

Administrativo

Direção Geral

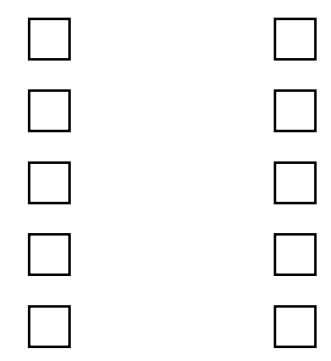

04 Quais as principais atividades desenvolvidas no setor comercial? Qual o número de funcionários utilizados nesta atividade? Eles possuem os requisitos necessários para essas atividades? 
05 Quais as principais atividades desenvolvidas no setor de hospedagem? Qual o número de funcionários utilizados nesta atividade? Eles possuem os requisitos necessários para essas atividades?

06 Quais as principais atividades desenvolvidas no setor de alimentos \& bebidas? Qual o número de funcionários utilizados nesta atividade? Eles possuem os requisitos necessários para essas atividades?

07 Quais as principais atividades desenvolvidas no setor administrativo (finanças, recursos humanos, manutenção)? Qual o número de funcionários utilizados nesta atividade? Eles possuem os requisitos necessários para essas atividades?

08 Quais as principais atividades desenvolvidas pela Direção Geral? Qual o número de funcionários utilizados nesta atividade? Eles possuem os requisitos necessários para essas atividades?

09 Quantas pessoas decidem como utilizar os recursos (financeiros, humanos etc) na empresa? Quais as funções ocupadas por essas pessoas?

10 A autoridade é distribuída em níveis hierárquicos?

11 Qual (is) a (s) forma (s) de transmissão (oral ou escrita) e recebimento de informações dentro da empresa?

12 Qual o conteúdo desta comunicação?

\section{Especificidades Comportamentais - Caracterização do dirigente da empresa}

13 Na sua opinião quais características são importantes para ser dirigente de uma empresa:

Autoconfiança

Domínio

Autonomia

Adaptabilidade

Sociabilidade

Firmeza 


\begin{tabular}{|c|c|c|}
\hline Segurança & Sensibilidade & Otimismo \\
\hline Automotivação & Criatividade & Vontade de realizar \\
\hline Necessidade de realização & mansidão & passividade \\
\hline lealdade & ambição & gressividade \\
\hline
\end{tabular}

Confiança em controlar o próprio destino

Corre riscos moderados

\section{(não falar sobre as opções)}

14 Como você gostaria de ser visto pela sociedade, pelos seus concorrentes, pelos seus familiares e pelos seus funcionários:

\begin{tabular}{|c|c|c|}
\hline Confiante & Dominador & Persuasivo \\
\hline Personalista & Sociável & Constante \\
\hline Seguro & Perspicaz & Otimista \\
\hline Motivado & Criativo & Voluntarioso \\
\hline
\end{tabular}

\section{(não falar sobre as opções)}

15 Quais os tipos de conhecimentos e habilidades (e aptidões), que você julga necessário para a boa gestão do negócio:

$\square$ Hotelaria

$\square$ Finanças

$\square$ Estratégia

$\square$ Outros $\square$ Turismo

$\square$ Marketing

Gestão da informação $\square$ Gestão de pessoas

$\square$ Operações de serviços

$\square$ Gestão da pequena empresa

Capacidade de compreender e lidar com a complexidade organizacional

Capacidade de lidar com as pessoas

Conhecimento das atividades específicas do gerente de uma empresa

\section{(não falar sobre as opções)}

16 Qual a sua opinião sobre as técnicas administrativas? Elas realmente ajudam a administrar os pequenos empreendimentos? 
17 Qual a sua opinião sobre as tecnologias da informação?

18 O que você acredita ser mais relevante para a gestão do negócio?

Capacidade empreendedora do empresário

A Influência das forças ambientais

A estrutura da empresa

\section{(não falar sobre as opções)}

19 Na sua opinião o dirigente deve:

$\square \quad$ Consultar os funcionários antes de tomar decisões

$\square \quad$ Decidir sem consultar os funcionários

$\square \quad$ Deixar por conta dos subordinados as decisões na empresa

\section{Especificidades Tecnológicas - Caracterização da tecnologia utilizada na empresa}

20 Os funcionários conhecem os equipamentos (ferramentas, aparelhos) que são utilizados no hotel? Os procedimentos para a realização da tarefa (do trabalho) e ainda possuem habilidades múltiplas (por exemplo, informar sobre o turismo na cidade, interagindo com os turistas).

21 Quais as tecnologias da informação utilizadas pela empresa? Essas tecnologias são utilizadas em operações, como um recurso para a tomada de decisão (sistema de informação) ou como uma arma estratégica?

22 A empresa já desenvolveu ou se preocupa em desenvolver um produto ou processo que the proporcione uma vantagem sobre os concorrentes?

23 A empresa tem condições (ou capacidade) de aplicar novos conhecimentos na prestação de serviços? 


\section{E. Especificidades Estratégicas}

24 A empresa utiliza a técnica de planejamento estratégico? Quem o coordena o planejamento estratégico?

25 Existem informações disponíveis para a realização do planejamento?

26 Os planos e decisões do planejamento são descritos em um documento e divulgados na empresa?

27 Existe uma visão externa a empresa?

28 Existe uma visão interna da empresa?

29 Existe uma visão de longo prazo? Qual a abrangência do plano?

\section{F. Gerenciamento Estratégico da Informação Interna na Pequena Empresa F1 - Administração estratégica}

30 Como é elaborada a estratégia na empresa (qual o processo - visão externa, interna e de longo prazo - de escolha do caminho de longo prazo que a empresa deve seguir)?

31 Após a escolha da estratégia empresarial, quais são as principais ações realizadas na empresa para colocar em prática a estratégia?

32 Durante a execução da estratégia escolhida, o desempenho da empresa é acompanhado? Como? 
F2 - Tipos e fontes de Informação estratégica disponível internamente no hotel

\begin{tabular}{|c|c|c|c|c|}
\hline $\begin{array}{c}\text { Atividades } \\
\text { do hotel }\end{array}$ & $\begin{array}{l}\text { Tipos de informação para } \\
\text { identificar pontos fortes e } \\
\text { fracos do hotel }\end{array}$ & $\begin{array}{c}\text { Tipos de informação para } \\
\text { acompanhar o } \\
\text { desempenho do hotel }\end{array}$ & $\begin{array}{c}\text { Grau de } \\
\text { importância } \\
\text { do tipo de } \\
\text { informação } \\
(*)\end{array}$ & $\begin{array}{c}\text { Fontes de } \\
\text { informação }\end{array}$ \\
\hline $\begin{array}{l}\text { Marketing } \\
\text { (comercial) }\end{array}$ & & & & \\
\hline $\begin{array}{l}\text { Alimentos \& } \\
\text { Bebidas }\end{array}$ & & & & \\
\hline Hospedagem & & & & \\
\hline $\begin{array}{l}\text { Administrativo } \\
\text { (finanças, } \quad R H \\
\text { e outros) }\end{array}$ & & & & \\
\hline
\end{tabular}

(*) Classifique em:

(1) Importante

(2) Média importância

(3) Pouca importância 


\section{F3 - Gestão da informação}

33 Sua empresa reconhece a importância da informação para a administração do negócio? Quais os benefícios (ou produtos) provenientes do gerenciamento das informações na empresa?

34 Existe alguém na empresa responsável pelo gerenciamento da informação, de forma a diagnosticar o que está acontecendo dentro e fora da empresa no momento atual (presente) e o que pode acontecer no futuro?

35 Como são identificadas as necessidades de informação dos decisores? Como são selecionados os tipos de informação necessários? Como é feita a escolha das fontes onde serão coletadas as informações? Quais os critérios desta escolha?

36 Como é realizada a coleta dos dados?

37 Depois de coletados os dados, como eles são classificados (codificados antes do arquivamento), ou seja, como são transformados em informação (processados)?

38 Qual (is) o (s) local (is) de armazenamento dos dados e informações (papel, disquete etc)?

39 Como são apresentados (relatórios, tabelas, gráficos, quadro de avisos) e distribuídos os dados e informações para as pessoas dentro da empresa?

40 Como as informações são utilizadas? Que tipos de decisão são tomados com base nas informações?

41 Como as especificidades da pequena empresa podem influenciar a gestão da informação? 


\section{APÊNDICE D - Apresentação dos dados}

\section{Hotel A}

O principal dirigente entrevistado é um dos proprietários do hotel e é responsável pela gerência de manutenção, hospedagem e eventos, além de participar da direção geral do hotel.

\section{a) Análise estratégica}

Segundo o dirigente entrevistado, existe a preocupação com o planejamento estratégico, mas essa reflexão sobre o futuro do hotel é informal. $\mathrm{Na}$ sua opinião, possivelmente, não é preciso formalizar esta atividade, pois não é muito usual; diferentemente dos procedimentos utilizados pelas camareiras para arrumarem os quartos dos hóspedes. Para ele "a visão sobre o futuro da empresa cresce de acordo com o crescimento da conta bancária".

A título de ilustração citou dois exemplos de decisão estratégica: a entrada no mercado de eventos no ano de 2002 e a construção de dez novos quartos seis meses atrás, para atender a uma maior quantidade de clientes. Outra estratégia importante que está sendo preparada para ser colocada em prática, visando o atendimento de mais hóspedes, é a ampliação do restaurante. O entrevistado disse também que "algumas estratégias surgem das conversas com os outros membros da família".

Existe a visão de longo prazo, mas nada é escrito, todos (a família) imaginam como querem o hotel daqui a alguns anos. "Os planos estão na cabeça da família e esporadicamente são descritos nas atas de reuniões, que estão em baixa na empresa". Atualmente, as reuniões para discutir o futuro da empresa normalmente são informais, e "não existe uma data definida para que ocorra, é de acordo com o tempo dos integrantes da família e das necessidades do hotel". Há também uma preocupação em ter um plano para toda a organização, "para que todos corram atrás do mesmo objetivo".

A visão externa da empresa é operacionalizada, principalmente, pelo monitoramento da opinião dos clientes. A liderança do hotel está preocupada também em identificar o que faz de melhor em relação aos seus concorrentes, como a flexibilidade para resolver problemas operacionais, e o que está ficando a desejar para melhor atender seus hóspedes, 
como é o caso do restaurante, que representa a visão interna do empreendimento. A maioria das informações disponíveis é sobre o funcionamento do hotel. Na opinião do entrevistado, estas são suficientes, para que a família pense o futuro do empreendimento. "Existindo uma preocupação em analisar a situação financeira da empresa, antes da realização de qualquer investimento".

\section{b) Especificidades da pequena empresa}

Os dados coletados se referem às especificidades ambientais, estruturais, comportamentais do dirigente, tecnológicas e estratégicas.

Quanto aos agentes do ambiente que podem influenciar o hotel, o entrevistado citou os concorrentes, os clientes, os fornecedores, o poder público municipal e federal, os bancos e as entidades de classe.

No ambiente operacional, o hotel possui um concorrente direto que possui padrão semelhante de atendimento. As desvantagens da empresa estão na estrutura física e no preço (o concorrente não paga ISS). Sua vantagem está na qualidade e flexibilidade do atendimento. Os fornecedores são muitos (locais e estaduais) e não oferecem no momento nenhuma ameaça ao hotel. Os clientes têm cada vez mais procurado o hotel fazenda e não costumam reclamar dos preços pagos pelos serviços.

Quanto às forças do macroambiente, inicialmente foi falado sobre a situação econômica atual do país. Segundo o dirigente, "a recessão tem influenciado a demanda, mas o cliente não deixou de freqüentar o hotel, como ocorreu com a maioria dos empreendimentos hoteleiros da cidade". A empresa tem uma capacidade maior de passar por uma recessão, pois não busca dinheiro em banco. Os investimentos são realizados apenas com capital próprio. Quanto à política fiscal, a empresa possui o simples, e acredita que os impostos não têm onerado em demasia os negócios. De forma geral, quando se refere às ações do poder público, o entrevistado afirma que "não atrapalhando, está bom".

A empresa não possui nenhuma relação com instituições de ensino e participa da Associação Brotas Capital da Aventura, apenas para divulgação da cidade em eventos. Para o entrevistado, há uma grande dificuldade em unir os empresários, inclusive nas reuniões do COMTUR que é dominado pela prefeitura. No entanto, ele tem consciência que sozinho não consegue influenciar as forças do macroambiente, como diminuir o ISS cobrado pela prefeitura, por exemplo. 
Quanto às características estruturais típicas, o hotel possui três unidades de trabalho no nível administrativo, gerenciadas pelos proprietários que ocupam cumulativamente a direção geral do empreendimento, e mais 16 funcionários para as operações do dia-a-dia. As atribuições dos funcionários são formalizadas, isto é, os procedimentos para realização das tarefas são estabelecidos e escritos, "facilitando a cobrança" por parte dos dirigentes e existe por parte da empresa, uma preocupação com a qualificação do seu nível operacional, onde alguns desses funcionários são incentivados a participarem de cursos de hotelaria e turismo.

A autoridade é distribuída em níveis hierárquicos, conforme é demonstrado no organograma da empresa (figura 25, p.79). As principais decisões, como utilização de recursos humanos e financeiros, são tomadas por toda a família e a comunicação é predominantemente oral, com exceção dos procedimentos para realização das tarefas, que são escritos. Para o entrevistado, para tomar decisões estratégicas, a família decide sem consultar os funcionários; para decisões operacionais os colaboradores poderão ser consultados antes da tomada de decisão.

Quanto às especificidades comportamentais do dirigente, o entrevistado citou como importante para quem dirige a empresa, as seguintes características: autoconfiança, honestidade, justiça, perseverança, praticidade e vontade de realizar os sonhos. Ele gostaria de ser visto pela sociedade e funcionários como uma pessoa que cumpre os compromissos assumidos e não realiza propaganda enganosa.

$\mathrm{Na}$ sua opinião o dirigente precisa adquirir conhecimentos e habilidades relacionados à hotelaria, à gestão, ao turismo, às finanças entre outros, para que consiga compreender e lidar com a complexidade da empresa. Possui uma opinião favorável sobre as técnicas administrativas, mas faz uma ressalva: “é necessário conhecer os benefícios das técnicas, antes de sua aplicação". Mencionou inclusive que já contratou um consultor para implantar o programa de qualidade 5S e que espera aprender algo de relevante para o negócio com a pesquisa. É favorável também à utilização da T.I. nas atividades do hotel.

Quanto às especificidades tecnológicas, o hotel utiliza as seguintes tecnologias: telefone, fax, página do hotel na internet, computador, rádio HT (para comunicação entre funcionários), corta energia (desliga a energia e informa a saída do hóspede do apartamento para que se possa realizar a limpeza). 
O computador é utilizado para agenda telefônica (controle dos gastos com telefone dos hóspedes), ponto dos funcionários, armazenamento de dados dos clientes, ou seja, na maior parte das vezes, com a finalidade de contribuir para a realização e controle das operações da empresa. Já o site da empresa disponível na internet, é utilizado pelo cliente para cadastrar seus dados e receber informações sobre os eventos do hotel.

No hotel os funcionários são treinados para utilização dos equipamentos e realização das tarefas (monitores, faxineiros, cozinheira). Reuniões são realizadas com os encarregados e com os funcionários da linha de frente para transmitir a melhor maneira de realização das tarefas, proporcionando o melhor atendimento ao turista. As camareiras, por exemplo, são treinadas para entenderem, também, o trabalho dos monitores da área de lazer (atividades de campo), compreendendo o funcionamento total do hotel e prestando informações aos hóspedes. "Existe a preocupação em profissionalizar os funcionários" por parte da empresa.

A empresa está sempre procurando participar de eventos e feiras, para conhecer novas tecnologias e buscar inovações; inclusive na utilização de novas técnicas administrativas. Por isso, o entrevistado acredita que é possível o hotel aplicar novos conhecimentos para se diferenciar do concorrente. Na sua opinião, "o produto oferecido é uma inovação por ser uma fazenda". Existindo uma constante busca pela inovação, principalmente na prestação do serviço.

\section{c) Informação estratégica (interna)}

Inicialmente foram identificados os tipos e fontes de informações (figura 34), que o hotel utiliza para diagnosticar seus pontos fortes e seus pontos fracos.

Percebe-se, claramente, a preocupação em utilizar informações para avaliação da situação financeira da empresa, que é muito relevante quando se pensa em tomar decisões relativas a investimentos (ampliação do restaurante, construção de apartamentos, construção do centro de convenções etc). No entanto, para o dirigente, a disponibilidade dessas informações é mínima, e "é preciso gerenciar melhor este tipo de informação".

O dirigente da empresa reconhece a importância da informação para a administração do negócio e afirma: sem a informação ficamos no escuro sem saber que direção seguir. “Ou que decisão tomar, se não sabemos o que está acontecendo dentro e fora do hotel". 
Segundo o entrevistado, os responsáveis pelo acompanhamento informal das informações são a gerente de administração e o gerente de manutenção do hotel fazenda, por estarem mais próximos dos funcionários e também por serem os representantes da empresa nas atividades externas (feiras, reunião no COMTUR, dar entrevistas, atender pesquisadores, etc).

\begin{tabular}{|c|c|c|c|c|}
\hline $\begin{array}{c}\text { Atividades } \\
\text { do hotel }\end{array}$ & $\begin{array}{l}\text { Tipos de informação para } \\
\text { analisar recursos } e \\
\text { capacidades do hotel no } \\
\text { momento atual }\end{array}$ & $\begin{array}{l}\text { Tipos de informação } \\
\text { para analisar o } \\
\text { desempenho atual do } \\
\text { hotel }\end{array}$ & $\begin{array}{l}\text { Grau de } \\
\text { importância } \\
\text { do tipo de } \\
\text { informação }\end{array}$ & $\begin{array}{l}\text { Fontes de } \\
\text { informação }\end{array}$ \\
\hline $\begin{array}{l}\text { Marketing } \\
\text { (comercial) }\end{array}$ & $\begin{array}{l}\text { - } \quad \begin{array}{l}\text { Forma de pagamento } \\
\text { - }\end{array} \\
\text { - (internet) } \\
\text { - } \quad \text { Tipo de produto } \\
\text { - } \quad \text { Preço }\end{array}$ & - Opinião dos clientes & Importante & $\begin{array}{ll}\text { - } & \text { Clientes } \\
\text { (questionário) }\end{array}$ \\
\hline $\begin{array}{l}\text { Alimentos \& } \\
\text { Bebidas }\end{array}$ & $\begin{array}{ll}\text { - } & \begin{array}{l}\text { Processo de produção } \\
\text { (procedimentos) }\end{array} \\
\text { - } & \text { Higiene } \\
\text { - } & \text { Insumos } \\
\text { - } & \text { Equipamentos } \\
\text { - } & \text { Arranjo físico }\end{array}$ & $\begin{array}{ll}\text { - } & \text { Qualidade } \\
\text { - } & \text { Nível de estoque } \\
\text { - } & \text { Refeições vendidas } \\
\text { - } & \text { Opinião dos clientes }\end{array}$ & Importante & $\begin{array}{ll}\text { - } & \text { Funcionários } \\
\text { - } & \text { Observação } \\
\text { - } & \text { Cliensoal } \\
& \text { (questionário) }\end{array}$ \\
\hline Hospedagem & $\begin{array}{ll}\text { - } & \text { Higiene e limpeza } \\
\text { - } & \text { Tecnologia de operação } \\
\text { (procedimentos) } \\
\text { - } & \text { Custos de manutenção } \\
\text { - } & \text { Equipamentos } \\
\text { Jardinagem } \\
\text { (manutenção) } \\
\text { - } & \text { Instalações } \\
\end{array}$ & $\begin{array}{ll}\text { - } & \text { Quantidade de } \\
\text { Equipamentos } \\
\text { funcionando } \\
\text { - } & \text { Opinião dos clientes }\end{array}$ & Importante & $\begin{array}{ll}\text { - } & \text { Funcionários } \\
\text { - } & \text { Observação } \\
\text { - } & \text { Cliensoal } \\
& \text { (questionário) }\end{array}$ \\
\hline $\begin{array}{l}\text { Administrativo } \\
\text { (finanças, } R H \\
\text { e outros) }\end{array}$ & $\begin{array}{l}\text { - Observância dos direitos } \\
\text { e deveres dos } \\
\text { funcionários (leis } \\
\text { trabalhistas) } \\
\text { Competências dos } \\
\text { funcionários (postura, } \\
\text { educação) }\end{array}$ & $\begin{array}{l}\text { - } \text { Opinião dos clientes } \\
\text { Controle dos } \\
\text { hóspedes } \\
\text { Acompanhamento } \\
\text { do fluxo de caixa } \\
\text { diário } \\
\text { Gastos com } \\
\text { aquisição de } \\
\text { matéria-prima } \\
\text { (compras) }\end{array}$ & Importante & $\begin{array}{ll}\text { - } & \text { Encarregados } \\
\text { - } & \text { Observação } \\
\text { - } & \text { pessoal } \\
& \text { Clientes } \\
\text { - } & \text { (questionário) } \\
\text { - } & \text { Extrato Bancário } \\
& \text { Relatório de } \\
\text { gastos }\end{array}$ \\
\hline
\end{tabular}

Figura 34 - Dados coletados nas entrevistas (hotel A)

Fonte: elaboração própria

Normalmente, as informações relativas ao negócio são coletadas em reuniões com funcionários e fora do hotel, pela observação pessoal e por meio do questionário preenchido pelos clientes. São armazenadas na mente dos dirigentes, em fichas, no caderno e no computador. No entanto, "existe dificuldade para recuperar esses dados, quando são 
necessários", afirma o dirigente. Os dados mais organizados e considerados mais relevantes para o empreendimento são os relativos à opinião dos clientes.

Os dados e as informações são apresentados aos colaboradores através do fluxo diário de atividades, de reuniões com os funcionários, dos procedimentos formais para realização de tarefas e de conversas informais entre dirigentes e encarregados.

Quando perguntado como as especificidades da pequena empresa podem influenciar a gestão da informação, o entrevistado citou quatro características:

- A informalidade na comunicação e nas relações entre as pessoas dentro do hotel;

- Falta de conhecimento por parte dos funcionários;

- Falta de tempo por parte da família;

- Falta de pessoas qualificadas para implantar o processo de gestão da informação.

\section{Hotel B}

O dirigente entrevistado é o gerente da pousada e é responsável também pelas atividades de marketing e finanças.

\section{a) Análise estratégica}

Segundo o gerente, existe a preocupação em refletir sobre o futuro do hotel, mas de maneira informal. A título de ilustração citou o exemplo da última decisão estratégica: a parceria realizada com as agências de viagens da cidade de São Paulo e do interior de Minas Gerais para captar novos clientes. Ele diz que, com base nas informações dos clientes, a direção pensa em construir outros tipos de chalés, novo salão de convenções etc, e afirma: "espero vivenciar o crescimento da pousada".

Existe a visão de longo prazo, mas nada é escrito, o proprietário imagina como quer o hotel e faz, afirma o gerente. Os planos de investimento estão na cabeça dele e nós funcionários só ficamos sabendo do que se trata quando ele for implementar. Desde o início das atividades da pousada os funcionários sabem da idéia do proprietário de aumentar a quantidade e diversificar os chalés, mas não sabem quando e como, diz o gerente.

A visão externa da empresa é operacionalizada principalmente pelo monitoramento: da opinião dos clientes e das ações dos concorrentes e pelas viagens realizadas pelo proprietário, para observar outros empreendimentos hoteleiros. "Precisamos sempre ficar 
de orelha em pé com o que está acontecendo fora da pousada", afirma o gerente. O hotel está preocupado também em identificar o que faz ou tem de melhor em relação aos seus concorrentes (localização, mais liberdade dentro do hotel) e o que está ficando a desejar para o melhor atendimento aos hóspedes (falta de alguns equipamentos - ar condicionado, interfone). Na opinião do gerente, "sempre existe um ponto positivo que não é possível copiar". Ele afirma também que sempre é perguntado aos clientes sobre os problemas do hotel. Após isso, pensa-se até que ponto os problemas apontados podem acarretar na perda do cliente. A partir dessa constatação são estabelecidas prioridades.

\section{b) Especificidades da pequena empresa}

Os dados coletados se referem às especificidades ambientais, estruturais, comportamentais do dirigente, tecnológicas e estratégicas.

Quanto aos agentes do ambiente que podem influenciar o hotel, o entrevistado citou os concorrentes, os clientes, os fornecedores, o poder público e as instituições de ensino.

O gerente não especificou nenhum concorrente direto, ele acredita numa concorrência saudável entre os empreendimentos hoteleiros de Brotas e disse: "ninguém prejudica ninguém”, cada um tem sua parcela no mercado, cada um tem os seus diferenciais e "nossa vantagem está nos chalés, fugindo ao padrão de Brotas". A pousada é um lugar amplo, tem sauna, piscina, mais liberdade para caminhar dentro do próprio hotel e flexibilidade no atendimento, diz o gerente. A desvantagem é a limitação de alguns equipamentos.

Para o dirigente, os fornecedores são muitos (locais e estaduais) "e o mercado é concorrido", não oferecendo no momento nenhuma ameaça ao hotel. "Os clientes procuram no mínimo um colchão e um chuveiro legal”. A negociação por preço tem ocorrido apenas na baixa temporada, na alta temporada faltam chalés para atender a demanda. "Aí o que vale é a lei da oferta e da procura", afirma o gerente.

Quanto às forças do macroambiente, inicialmente foi falado sobre a situação econômica atual do país. Segundo o gerente, "a recessão contribui para que aumente a negociação com os clientes por um preço mais baixo". Quanto à política fiscal do município, o entrevistado afirmou que os impostos possuem uma alíquota muito alta e que 
"a prefeitura só cai em cima de quem está regularizado", querendo aumentar ainda mais a carga tributária.

A empresa não possui nenhuma relação com instituições de ensino, mas o gerente afirma que elas poderiam ajudar os empresários. "O problema é que elas estão fora da realidade, mas mesmo assim, às vezes oferecem alguns bons treinamentos" e nos ajudam.

O gerente não participa das reuniões do COMTUR e diz, sem muita empolgação, do conselho: "existem pequenos grupos de interesse dentro do conselho" e isso não ajuda em nada no desenvolvimento do setor turístico de Brotas. Mostrou inclusive uma reportagem no jornal local para comprovar a sua opinião. No entanto, ele tem consciência de que sozinho não consegue influenciar as forças do macroambiente.

Quanto às características estruturais típicas, o hotel possui cinco funcionárias para as tarefas diárias e dois funcionários no nível administrativo: o gerente, que também desempenha as atividades de marketing e finanças; e a governanta que é responsável pelas atividades de hospedagem, $\mathrm{A} \& \mathrm{~B}$, compras e contratação das funcionárias relacionadas ao seu setor. $\mathrm{O}$ gerente realiza concomitantemente atividades operacionais (cadastra hóspedes, responde e-mails etc) e administrativas (analisa o cadastro de clientes, apresenta ao proprietário, semanalmente, o relatório financeiro etc).

As atribuições dos funcionários não são formalizadas (os procedimentos para realização das tarefas), mas segundo o gerente, todos sabem a sua responsabilidade. No entanto, "quando o serviço aperta, um ajuda o outro, pois a nossa estrutura é pequena, mas atende as necessidades de uma empresa que está começando". Outro aspecto importante citado pelo entrevistado é que nenhum funcionário tinha trabalhado no setor hoteleiro anteriormente.

A autoridade é distribuída em níveis hierárquicos, conforme é demonstrado no organograma da empresa (figura 26, p.81). As decisões relacionadas a investimentos ou contratação de funcionários são tomadas pelos proprietários. O gerente apenas fornece as informações solicitadas pelos dirigentes. As demais decisões (política de preços, por exemplo) são tomadas pelo gerente sem interferência dos proprietários. A comunicação é predominantemente oral.

Quanto às especificidades comportamentais do dirigente, o gerente entrevistado citou como importante para quem dirige a empresa as seguintes características: 
versatilidade, honestidade, iniciativa e flexibilidade. Ele gostaria de ser visto pela sociedade e funcionários como um dirigente motivado e afetivo, que trabalha e faz e cumpre o que promete.

$\mathrm{Na}$ opinião do gerente, é necessário adquirir conhecimentos e habilidades relacionados a hotelaria, gestão e turismo entre outros, para que seja possível compreender e lidar com complexidade da empresa. Diz: "às vezes você tem até iniciativa, mas não sabe como agir, ou seja, tem uma idéia, mas não sabe colocar em prática, falta conhecimento". O gerente também tem uma opinião favorável sobre as técnicas administrativas, mas faz uma ressalva: "nem tudo é possível ou necessário ao tipo de negócio. Nós precisamos (a cidade de Brotas) de um curso sobre legislação, para que saibamos os direitos e deveres dos clientes. "Não precisa ser um curso universitário com 15 anos de duração", ironiza o dirigente.

E continua: precisamos também de cursos (vendas, por exemplo) direcionados ao público do turismo, ou seja, específico para o nosso setor e suas peculiaridades. "Ser vendedor em uma loja de departamento é diferente de ser vendedor em um hotel". Para o gerente, Brotas não têm muita gente especializada em turismo e isso faz com que apenas o atendimento diferenciado proporcione bom retorno financeiro.

O gerente é favorável e utiliza a tecnologia da informação para realizar as suas tarefas no hotel. Mencionou inclusive a carência dessa tecnologia no check out dos hóspedes. E por fim afirmou que é sempre positivo o dirigente consultar os funcionários antes de tomar decisões importantes.

Quanto às especificidades tecnológicas, o hotel utiliza as seguintes tecnologias: telefone, fax, página do hotel na internet, software aplicativo, computador e rádio HT (para comunicação entre os funcionários). O site da empresa disponível na internet, é utilizado pelo cliente para obter informações sobre a pousada. Já o computador é utilizado basicamente para armazenar dados dos clientes, fazer planilhas de controle etc.

Os funcionários do hotel não foram treinados para utilização dos equipamentos e realização das tarefas (monitores, faxineiros, cozinheira), "começamos do zero" diz o gerente. $\mathrm{O}$ que sabemos hoje, foi com base na experiência nesses quase dois anos de atividade do hotel. O gerente está sempre procurando conhecer novas tecnologias e técnicas administrativas para aplicar na pousada. Para o entrevistado “o empreendimento já nasceu 
diferenciado" pelas suas instalações. Hoje sua preocupação está concentrada na diferenciação pelo atendimento. "Somos muito flexíveis no check in e no check out e também no prazo de pagamento", afirma o gerente.

c) Informação estratégica (interna)

Inicialmente foram identificados os tipos e fontes de informações (figura 35) que o hotel utiliza para diagnosticar seus pontos fortes e seus pontos fracos.

\begin{tabular}{|c|c|c|c|c|}
\hline $\begin{array}{l}\text { Atividades } \\
\text { do hotel }\end{array}$ & $\begin{array}{c}\text { Tipos de informação } \\
\text { para identificar } \\
\text { pontos fortes e fracos } \\
\text { do hotel }\end{array}$ & $\begin{array}{l}\text { Tipos de informação } \\
\text { para acompanhar o } \\
\text { desempenho do hotel }\end{array}$ & $\begin{array}{c}\text { Grau de } \\
\text { importância } \\
\text { do tipo de } \\
\text { informação }\end{array}$ & $\begin{array}{l}\text { Fontes de } \\
\text { informação }\end{array}$ \\
\hline $\begin{array}{l}\text { Marketing } \\
\text { (comercial) }\end{array}$ & $\begin{array}{ll}\text { - } & \text { Preço } \\
\text { - } & \text { Propaganda } \\
\text { - } & \text { Produto } \\
& \text { (comodidade, } \\
\text { conforto, } & \text { localização, } \\
& \text { atendimento) }\end{array}$ & $\begin{array}{l}\text { - } \begin{array}{l}\text { Índice de retorno do } \\
\text { cliente }\end{array} \\
\text { (informalmente) } \\
\text { - Opinião do cliente }\end{array}$ & Importante & $\begin{array}{ll}\text { - } & \text { Folder } \\
\text { - } & \text { Cliente } \\
\text { - } & \text { Concorrente } \\
& (\text { preço })\end{array}$ \\
\hline $\begin{array}{l}\text { Alimentos \& } \\
\text { Bebidas }\end{array}$ & $\begin{array}{ll}\text { - } & \text { Custos } \\
\text { - } & \text { Diversificação de } \\
& \text { pratos }\end{array}$ & $\begin{array}{ll}\text { - } & \text { Qualidade } \\
\text { - } & \text { Opinião do cliente }\end{array}$ & Importante & $\begin{array}{l}\text { Observação } \\
\text { pessoal } \\
\text { - } \quad \text { Cliente }\end{array}$ \\
\hline Hospedagem & $\begin{array}{ll}\text { - } & \text { Custos } \\
\text { - } & \text { Higiene e limpeza } \\
\text { - } & \text { Equipamentos } \\
\text { - } & \text { Instalações }\end{array}$ & - Opinião do cliente & Importante & $\begin{array}{l}\text { Observação } \\
\text { pessoal } \\
\text { - Cliente }\end{array}$ \\
\hline $\begin{array}{l}\text { Administrativo } \\
\text { (finanças, } R H \\
\text { e outros) }\end{array}$ & $\begin{array}{l}\text { - Habilidades das } \\
\text { funcionárias }\end{array}$ & $\begin{array}{l}\text { - Entradas e saídas de } \\
\text { caixa }\end{array}$ & Importante & 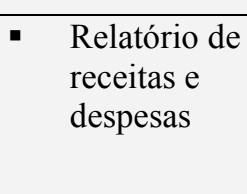 \\
\hline
\end{tabular}

Figura 35 - Dados coletados nas entrevistas (hotel B)

Fonte: elaboração própria

O gerente reconhece a importância da informação para a administração do negócio. A título de exemplo mencionou o caso em que o hotel sem base em informações aumentou em $20 \%$ o preço da sua diária e a demanda começou a diminuir. Após a constatação do fato fez uma pesquisa de preços e verificou que o valor da diária estava superestimado em relação à concorrência. 
O responsável principal pelo acompanhamento informal das informações é o gerente, que depois transmite as suas impressões a um dos proprietários. Sua preferência é ouvir a opinião dos clientes, que servirá de orientação para as futuras decisões.

Normalmente, as informações relativas ao negócio são coletadas em conversas com funcionários e fora do hotel, pela observação pessoal e por meio do questionário preenchido pelos clientes. São armazenadas na mente dos dirigentes, em fichas, e no computador. Mas não existe uma metodologia para coletar e organizar esses dados de forma estruturada, afirma o gerente.

Os dados e as informações são apresentados pelo gerente ao proprietário através do relatório de receitas e despesas e de conversas informais. Quando perguntado como as especificidades da pequena empresa podem influenciar a gestão da informação, o entrevistado citou duas características: falta de conhecimento e de tempo do gerente.

\section{Hotel C}

A dirigente entrevistada é filha do proprietário do hotel e é responsável pelas atividades de finanças, compras, $\mathrm{A} \& \mathrm{~B}$ e recursos humanos.

\section{a) Análise estratégica}

Segundo a dirigente, existe a preocupação em refletir sobre o futuro do hotel, mas de maneira informal. A título de ilustração citou o exemplo da última decisão estratégica: a venda de passeios turísticos pela pousada. "O aumento no faturamento foi considerável", afirma a dirigente. Ela afirma que com base nas informações dos clientes, pensa-se em melhorar a infra-estrutura da pousada, definir preços etc.

Existe a visão de longo prazo, mas nada é escrito, e todos imaginam a pousada daqui a alguns anos. "Os familiares têm consciência do que querem para o futuro do hotel", afirma a dirigente. Por meio de reuniões, sem uma data definida para que ocorra e de acordo com a disponibilidade de tempo dos membros da família e das necessidades do hotel, os familiares definem as ações futuras para toda a empresa.

A visão externa da empresa é operacionalizada principalmente pelo monitoramento: da opinião dos clientes, das ações dos concorrentes e do movimento do turismo em outras cidades (Bonito/MS). "A dirigente afirma que atualmente a concorrência é com outras 
cidades e os hotéis não lotam mais como antigamente". O hotel está preocupado também em identificar o que faz melhor em relação aos seus concorrentes (atendimento e preço acessível, por exemplo) e o que está ficando a desejar para melhor atender aos hóspedes (falta de alguns equipamentos). Para a entrevistada, as informações coletadas são suficientes para que a família reflita sobre o futuro da pousada.

\section{b) Especificidades da pequena empresa}

Os dados coletados se referem às especificidades ambientais, estruturais, comportamentais do dirigente, tecnológicas e estratégicas.

Quanto aos agentes do ambiente que podem influenciar o hotel, a dirigente citou os concorrentes, os clientes, os fornecedores, o poder público, os bancos e as entidades de classe.

$\mathrm{Na}$ opinião da dirigente o hotel possui um concorrente direto que atende aos mesmos segmentos de clientes (viajantes e praticantes de esportes radicais) e possui uma estrutura física semelhante. Sua principal desvantagem é a falta de equipamentos (ar condicionado, por exemplo). Suas vantagens estão no preço acessível e no atendimento. A dirigente afirma também, que os grandes hotéis têm melhores condições de atrair os clientes por causa da estrutura. Os fornecedores são em grande número (locais e estaduais) e não desfavorecem a pousada nas negociações. Com os clientes as negociações são com "igualdade de força", afirma a entrevistada. Ela afirma que o hotel atende dois segmentos: “40\% dos nossos hóspedes são viajantes e $60 \%$ procuram o turismo de aventura".

Quanto às forças do macroambiente, a dirigente iniciou a entrevista falando da economia do país. "A recessão atrapalhou o negócio. Com a incerteza da economia, viajar passou para o segundo plano dos turistas", diminuindo a demanda, afirma a entrevistada.

$\mathrm{Na}$ cidade "faltam bancos $24 \mathrm{H}$ e agência do banco Itaú" (conta da maioria dos clientes). "As taxas bancárias são altas, o atendimento é precário, os juros são altos (2,9\% a.m) e o limite de crédito disponível para investimento é de apenas R $\$ 15.000,00 ”$, afirma a dirigente. "Temos muitos projetos de ampliação da pousada na nossa cabeça, mas a restrição financeira nos impede de colocá-los em prática", ou seja, a realização dos investimentos necessários para o melhor atendimento do nosso cliente".

Em relação aos tributos federais, a pousada é integrante do SIMPLES, mas mesmo assim, a dirigente reclama do peso dos encargos trabalhistas. Quanto à política fiscal do 
município, ela afirma que a alíquota do ISS subiu para 5\% e "isto é injusto por causa das casas de aluguel que não pagam o imposto". De forma geral, quando se refere às ações do poder público municipal, a entrevistada acredita que a prefeitura tem tentado melhorar as condições do turismo na cidade. Para exemplificar cita as reuniões do COMTUR que ela participa a quatro anos, acreditando ser este um bom caminho para discutir políticas municipais de atração ao turista.

Embora a empresa não possua nenhuma relação com instituições de ensino, a nossa entrevistada acredita que estas capacitam os funcionários dos hotéis, no entanto afirma que o interesse maior não está direcionado aos empreendimentos de pequeno porte.

Quanto às características estruturais típicas, a família ocupa os cargos de nível administrativo no hotel. A mãe é a diretora geral e os três filhos cuidam das atividades de marketing, finanças, manutenção etc. Além das atividades administrativas a família trabalha na recepção em escala de horários e fiscaliza o trabalho das outras duas funcionárias que realizam as demais atividades operacionais do hotel. Mesmo informalmente as atribuições das pessoas estão bem divididas e todos têm consciência dos seus deveres. Segundo a dirigente existe também uma preocupação com a qualificação de todos funcionários.

A autoridade é distribuída em níveis hierárquicos, conforme é demonstrado no organograma da empresa (figura 27, p.82). As principais decisões (utilização de recursos humanos e financeiros, por exemplo) são tomadas pela gerente geral e pela gerente de finanças, a dirigente entrevistada. No entanto, todos os membros da família têm autonomia para conceder descontos aos hóspedes. A comunicação é predominantemente oral, e na maior parte sobre os acontecimentos diários. Para a entrevistada, a estrutura atual atende ("está de acordo") as necessidades do hotel.

$\mathrm{Na}$ opinião da entrevistada, o dirigente precisa adquirir conhecimentos e habilidades relacionados: a hotelaria, gestão, turismo, finanças entre outros, para que consiga lidar com complexidade da empresa e seja capaz de se relacionar com outras pessoas. Possui uma opinião favorável sobre as técnicas administrativas, mas afirma que as técnicas são muito complexa para a pequena empresa e "os livros não ajudam muito, é preciso adequar". A dirigente espera também a partir das entrevistas aprender algo de relevante para a gestão do negócio. É favorável também à utilização da T.I. nas atividades do hotel, mas não gosta 
muito de navegar pela internet, deixa esta tarefa para a responsável pelas atividades de marketing.

Quanto às especificidades tecnológicas, o hotel utiliza as seguintes tecnologias da informação: telefone, fax, página do hotel na internet, computador e planilha excel. "Não possuímos tecnologia sofisticada, pois o estilo do hotel é caseiro, temos lavanderia própria e não temos ar condicionado por falta de recursos financeiros", afirma a dirigente.

O computador é utilizado basicamente para elaborar planilhas que possam armazenar dados dos clientes e fazer o controle de reservas. Já o site da empresa, disponível na internet, é utilizado pelo cliente para receber informações sobre os serviços do hotel.

No hotel os funcionários conhecem os equipamentos e estão habilitados para a realização das tarefas. Estão capacitados também, para interagir com os clientes e informar inclusive sobre as cachoeiras de Brotas. Existe a preocupação em capacitar os funcionários por parte da empresa.

Por fim a dirigente afirma que a empresa procura atender as necessidades básicas dos seus hóspedes e não tem muita preocupação em criar produtos novos e sofisticados.

\section{c) Informação estratégica (interna)}

Inicialmente foram identificados os tipos e fontes de informações (figura 36) que o hotel utiliza para diagnosticar seus pontos fortes e seus pontos fracos.

A empresa reconhece a importância da informação para a administração do negócio. "É a base que possibilita organizar o hotel e dividir as funções", afirma a dirigente. A responsável pelo acompanhamento informal das informações é a gerente de finanças, segundo ela por ser a representante da empresa nas atividades externas (feiras, reunião no COMTUR, dar entrevistas, atender pesquisadores etc) e por gostar de realizar esta tarefa, que lhe permite ficar sabendo dos fatos que podem atrapalhar o andamento do negócio.

Normalmente as informações relativas ao negócio - que ajudam a melhorar o andamento do hotel e o atendimento aos hóspedes - são coletadas em reuniões com a família e fora do hotel, em conversas com os funcionários, pela observação pessoal e por meio do questionário preenchido pelos clientes. São armazenadas na mente dos dirigentes, no caderno, em disquete e no banco de dados. No entanto, existe dificuldade para recuperar 
esses dados, quando são necessários. Os dados mais relevantes para o empreendimento são os relativos a opinião dos clientes.

Os dados e as informações são apresentados em conversas informais entre os familiares e ajudam na definição do valor da diária, na escolha dos fornecedores, na melhora da infra-estrutura da pousada, na contratação de pessoal e na escolha das agências para estabelecer parcerias.

\begin{tabular}{|c|c|c|c|c|}
\hline $\begin{array}{l}\text { Atividades } \\
\text { do hotel }\end{array}$ & $\begin{array}{l}\text { Tipos de informação para } \\
\text { analisar recursose } \\
\text { capacidades do hotel no } \\
\text { momento atual }\end{array}$ & $\begin{array}{c}\text { Tipos de informação } \\
\text { para analisar o } \\
\text { desempenho atual do } \\
\text { hotel }\end{array}$ & $\begin{array}{c}\text { Grau de } \\
\text { importância } \\
\text { do tipo de } \\
\text { informação }\end{array}$ & $\begin{array}{c}\text { Fontes de } \\
\text { informação }\end{array}$ \\
\hline $\begin{array}{l}\text { Marketing } \\
\text { (comercial) }\end{array}$ & $\begin{array}{ll} & \text { Valor da diária } \\
\text { - } & \text { Atendimento } \\
& \text { Venda de passeios }\end{array}$ & - $\quad$ Opinião dos clientes & Importante & $\begin{array}{ll} & \text { Clientes } \\
\text { - } & \text { Banco de dados } \\
& \text { Telefone e e-mail }\end{array}$ \\
\hline $\begin{array}{l}\text { Alimentos \& } \\
\text { Bebidas }\end{array}$ & $\begin{array}{ll} & \text { Utensílios de cozinha } \\
\text { - } & \text { Custos } \\
& \text { Tipo de Alimento } \\
& \text { (natural) }\end{array}$ & - $\quad$ Opinião dos clientes & Importante & $\begin{array}{ll} & \text { Clientes } \\
\text { - } & \text { Funcionários } \\
& \text { pbservação } \\
\end{array}$ \\
\hline Hospedagem & $\begin{array}{ll} & \text { Higiene e limpeza } \\
\text { : } & \text { Equipamentos } \\
\text { Instalações }\end{array}$ & - Opinião dos clientes & Importante & $\begin{array}{ll}\text { - } & \text { Clientes } \\
\text { - } & \text { Funcionários } \\
& \text { pesservaçãa }\end{array}$ \\
\hline $\begin{array}{l}\text { Administrativo } \\
\text { (finanças, } R H \\
\text { e outros) }\end{array}$ & 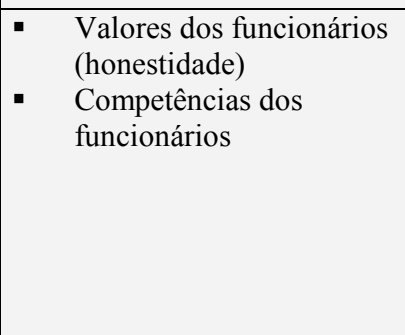 & $\begin{array}{ll} & \text { Opinião dos clientes } \\
\text { - } & \text { Faturamento } \\
\text { Acompanhamento } \\
\text { do fluxo de caixa } \\
\text { diário } \\
\text { Gastos com } \\
\text { aquisição de } \\
\text { matéria-prima } \\
\text { (compras) }\end{array}$ & Importante & $\begin{array}{ll} & \text { Fornecedores } \\
& \text { Clientes } \\
& \text { Notas fiscais }\end{array}$ \\
\hline
\end{tabular}

Figura 36 - Dados coletados nas entrevistas (hotel C)

Fonte: elaboração própria

Quando foi perguntado como as especificidades da pequena empresa podem influenciar a gestão da informação, a entrevistada citou falta de tempo por parte da família;

\section{Hotel D}

A entrevistada é proprietária e dirigente do hotel e é responsável por todas as atividades administrativas. 


\section{a) Análise estratégica}

Segundo a dirigente, existe a preocupação em refletir sobre o futuro da pousada, mas de maneira informal. Para ilustrar, mencionou a última decisão estratégica que ela tomou para alcançar o seu objetivo de atender a sessenta hóspedes simultaneamente: a construção de mais dois chalés com capital próprio.

Existe a visão de longo prazo, mas nada é escrito e a dirigente sabe como quer a pousada daqui a alguns anos e corre atrás dos seus sonhos. "Quando eu construí a pousada eu já tinha a meta de atender sessenta pessoas". O plano está na minha cabeça, "eu sei o que planejo, o que o cliente deseja e que ações devo desenvolver para realizar o plano". Por meio da reflexão individual, a empresária define as ações futuras que abrangem toda a empresa e comunica-as aos demais funcionários, para que todos saibam a meta a ser alcançada. "Tudo que é feito na empresa está dentro da minha visão de futuro", afirma a empresária.

A visão externa da empresa é operacionalizada principalmente pelo monitoramento da opinião dos clientes. A proprietária está preocupada também em identificar o que faz melhor em relação aos seus concorrentes (flexibilidade para resolver problemas operacionais, foco na tradição familiar, única pousada que recebe animal etc) e monitora constantemente os pontos negativos dos hotéis e pousadas da região para não cometer os mesmos erros. Procura também se prevenir em relação aos problemas (os pontos fracos), "mas às vezes as surpresas aparecem e é preciso solucionar os problemas", diz a entrevistada, para quem as informações coletadas são suficientes para que ocorra a reflexão sobre o futuro da pousada.

\section{b) Especificidades da pequena empresa}

Os dados coletados se referem às especificidades ambientais, estruturais, comportamentais do dirigente, tecnológicas e estratégicas.

Quanto aos agentes do ambiente que podem influenciar o hotel, a empresária citou os concorrentes, os clientes, os fornecedores, o poder público municipal e federal, os bancos e as entidades de classe.

Para a dirigente quanto mais concorrência melhor. Ela diz: eu tenho um diferencial em relação aos grandes hotéis. A pousada é a única a fornecer babá, podendo, também, receber animais de estimação para os quais possui espaço apropriado, concorrendo para que 
as pessoas se sintam em casa. Seu foco é na tradição (pratos típicos da vovó) e não quer que a pousada cresça além da sua meta para não perder o diferencial, o contato direto e mais informal com o turista.

O objetivo da pousada é atender famílias (inclusive de estrangeiros), fazendo com que eles se sintam no próprio lar. "A família representa bem o perfil do meu cliente". Como o preço dos grandes concorrentes é maior, os clientes têm um poder de barganha pequeno. Os fornecedores são muitos (locais, estaduais e regionais) e a negociação é facilitada. A proprietária faz uma seleção criteriosa dos fornecedores (qualidade do produto, por exemplo), de acordo com os objetivos que a pousada procura atender, para não ter que ficar mudando de fornecedor.

Quanto às forças do macroambiente, a economia trouxe uma baixa temporada ruim, afirma a dirigente. A demanda diminuiu consideravelmente nesse período, mas o empreendimento teve condições de superar esta adversidade. "A pousada foi triplicada nos últimos dois anos, e com capital próprio. O lucro foi reinvestido na construção de novos chalés. Esta é uma política da empresa. Banco nem pensar, os juros são exorbitantes”, afirma a empresária.

Em relação aos encargos trabalhistas, a dirigente afirma que estes pesam na baixa temporada, pois os custos com os funcionários permanecem os mesmos e a demanda diminui. Quanto às ações do poder público municipal, a empresária afirma que tenta conversar, mas a prefeitura ajuda pouco. Esta deveria divulgar a cidade e a preservação da natureza, isto é, fazer campanhas para o turismo sustentável. Em 1991, foi realizado um plebiscito e a população apoiou o turismo como principal atividade econômica da cidade.

Com relação às instituições de ensino, a empresária comentou o caso do seu filho que se formou em hotelaria numa instituição renomada. "Eles são sonhadores, formam pessoas para atuar numa realidade longe da brasileira. O curso é ideal para quem quer trabalhar em grandes hotéis internacionais. Mencionou também o caso dos estudantes de hotelaria da cidade de Piracicaba que fizeram estágio na pousada. "Os conhecimentos não eram aplicáveis ao meu empreendimento, pois os estudantes foram preparados para atuarem em hotéis de grandes cidades".

Quanto às características estruturais típicas, o hotel possui apenas uma unidade de trabalho no nível administrativo, comandada pela proprietária. Além da dirigente, a 
pousada possui mais seis funcionários (incluindo os dois filhos) para realizar as atividades no nível operacional. Todos os funcionários conhecem as suas atribuições e recebem as normas gerais de funcionamento da pousada quando são admitidos. Está sendo preparada uma ficha que contém os procedimentos para realização das tarefas, onde cada funcionário deverá assinar esta ficha após a realização do serviço. Segundo a empresária irá facilitar a avaliação do desempenho de seus funcionários. Ela afirma que as pessoas são mais qualificadas pelo treinamento do dia-a-dia (convivência) do que pelos cursos que possui.

A autoridade é distribuída em um nível hierárquico, conforme é demonstrado no organograma da empresa (figura 28, p.83). A empresária delega e supervisiona todas as atividades operacionais (hospedagem, A\&B, manutenção etc). As principais decisões (utilização de recursos humanos e financeiros, por exemplo) são tomadas por ela e a comunicação é predominantemente oral. "Para construir chalés eu decido. Se for para contratar uma nova funcionária eu procuro ouvir as outras funcionárias, pois eu quero alguém que seja adequada a nossa maneira de trabalhar, mas mesmo assim, no final a decisão é minha", afirma a dirigente. Na sua opinião, a estrutura atual é suficiente para atender as necessidades do negócio.

Quanto às especificidades comportamentais do dirigente, a empresária considera importante para todo dirigente de empresa as seguintes características: domínio do negócio, confiança para controlar o próprio destino, segurança, motivação e otimismo.

$\mathrm{Na}$ opinião da entrevistada todo dirigente precisa adquirir conhecimentos e habilidades relacionados: a hotelaria, gestão, turismo, finanças, cooperação entre outros. "O dirigente precisa entender o funcionamento total da empresa e saber lidar com as pessoas", afirma a empresária. Tem uma opinião favorável sobre as técnicas administrativas, mas afirma que "é preciso adequar as técnicas à realidade da pequena empresa". É favorável também à utilização da T.I. nas atividades do hotel. Através da internet a pousada está sendo divulgada em Portugal, na França e em outros países da Europa.

Quanto às especificidades tecnológicas, o hotel utiliza as seguintes tecnologias da informação na realização das tarefas operacionais: telefone, fax, internet, computador e o software hábil, que fornece informações sobre finanças, estoque etc.

O computador é utilizado principalmente para armazenar os dados dos clientes e ajudar na realização e controle das operações da empresa. Já o site da empresa disponível 
na internet, é utilizado pelo cliente para conhecer a pousada, solicitar informações, fazer reservas ou realizar críticas e sugestões.

$\mathrm{Na}$ pousada, os funcionários conhecem os utensílios que utilizam e as tarefas a serem realizadas. Não iniciam as atividades antes de participarem do treinamento. E esporadicamente participam de oficinas realizadas na cidade. Os funcionários também aprendem a interagir com outras pessoas, indo além de sua atividade técnica. Eles são capazes de prestar qualquer informação (interna) relativa ao hotel. As informações externas são de responsabilidade da proprietária.

A dirigente da pousada está sempre buscando inovar, principalmente na prestação do serviço. Ela afirma que "a empresa trabalha com todas as agências de esportes radicais da cidade de Brotas e isto é uma inovação. O turista não precisa se preocupar em agendar os passeios, tudo fica por conta do setor comercial do hotel".

\section{c) Informação estratégica (interna)}

Inicialmente foram identificados os tipos e fontes de informações (figura 37) que o hotel utiliza para diagnosticar seus pontos fortes e seus pontos fracos.

A empresária reconhece a importância da informação para a administração do negócio. "Sem a informação não é possível conduzir o negócio", fica muito difícil continuar na direção do objetivo. "Eu busco informação por causa do negócio, se não fosse isso, eu queria viver só a natureza", afirma a dirigente. Os responsáveis pelo acompanhamento informal das informações são a proprietária e um de seus filhos.

Normalmente, as informações relativas ao negócio são coletadas em reuniões com funcionários e pela observação pessoal da proprietária. A recuperação das informações é realizada por meio da consulta às fichas dos clientes e do programa hábil (informações financeiras). Os dados mais relevantes para o empreendimento são os relativos à opinião dos clientes.

As informações são transmitidas oralmente e por meio do quadro de aviso que fica na cozinha (tarefas e cardápio) e no salão do café (para os clientes).

Quando foi perguntado como as especificidades da pequena empresa podem influenciar a gestão da informação, a empresária citou a carência de informações 
financeiras. "as informações fornecidas pelo contador são insuficientes. Temos apenas três contadores na cidade, dificultando a escolha de um bom contador", afirma a dirigente.

\begin{tabular}{|c|c|c|c|c|}
\hline $\begin{array}{l}\text { Atividades } \\
\text { do hotel }\end{array}$ & $\begin{array}{c}\text { Tipos de informação para } \\
\text { analisar recursose } \\
\text { capacidades do hotel no } \\
\text { momento atual }\end{array}$ & $\begin{array}{c}\text { Tipos de informação } \\
\text { para analisar o } \\
\text { desempenho atual do } \\
\text { hotel }\end{array}$ & $\begin{array}{c}\text { Grau de } \\
\text { importância } \\
\text { do tipo de } \\
\text { informação }\end{array}$ & $\begin{array}{l}\text { Fontes de } \\
\text { informação }\end{array}$ \\
\hline $\begin{array}{l}\text { Marketing } \\
\text { (comercial) }\end{array}$ & $\begin{array}{ll} & \text { Preço da diária } \\
\text { - } & \text { Promoção (internet) } \\
\text { - } & \text { Atendimento } \\
\text { Vendas }\end{array}$ & - $\quad$ Opinião dos clientes & Importante & - $\quad$ Clientes \\
\hline $\begin{array}{l}\text { Alimentos \& } \\
\text { Bebidas }\end{array}$ & $\begin{array}{ll}\text { - } & \text { Custos } \\
\text { - } & \text { Higiene } \\
& \text { Qualidade dos Insumos }\end{array}$ & - Qualidade & Importante & $\begin{array}{ll}\text { - } & \text { Livro caixa } \\
\text { - } & \text { Observação } \\
\text { pessoal } \\
\text { - }\end{array}$ \\
\hline Hospedagem & $\begin{array}{ll}\text { - } & \text { Higiene e limpeza } \\
\text { Utensílios domésticos } \\
\text { Instalações }\end{array}$ & - $\quad$ Opinião dos clientes & Importante & $\begin{array}{ll}\text { - } & \text { Observação } \\
\text { pessoal } \\
\text { - Clientes }\end{array}$ \\
\hline $\begin{array}{l}\text { Administrativo } \\
\text { (finanças, } R H \\
\text { e outros) }\end{array}$ & 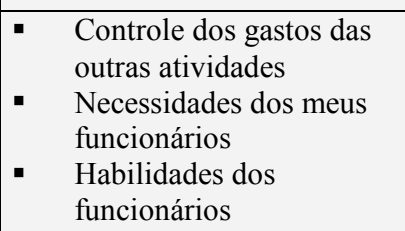 & $\begin{array}{l}\text { Informações } \\
\text { fornecidas pelo } \\
\text { software hábil } \\
\text { (financeiras) }\end{array}$ & Importante & $\begin{array}{ll} & \text { Observação } \\
\text { - } & \text { Lessoal } \\
\text { - } & \text { Contador caixa }\end{array}$ \\
\hline
\end{tabular}

Figura 37 - Dados coletados nas entrevistas (hotel D)

Fonte: elaboração própria

\section{Hotel E}

O dirigente entrevistado é gerente geral no hotel e tem como atribuições: determinar as prioridades operacionais e os investimentos do hotel e encaminhá-los à diretoria; dar suporte e resolver os problemas encaminhados pelas chefias; relacionar-se socialmente com os hóspedes e administrar as operações e as finanças do hotel.

\section{a) Análise estratégica}

Segundo o gerente geral, existe a preocupação com o planejamento estratégico, "mas não existe um plano formal definitivo, que se segue à risca; os objetivos mudam e a formalidade engessa o processo". Até o momento tem sido satisfatório, mas não é o ideal. Pois alguns investimentos são perdidos por falta de um plano de ação, como foi o caso do 
estacionamento subterrâneo (o hotel não possui estacionamento próprio). "Outras vezes existe o plano, mas não são colocados em prática por falta de recursos financeiros", como as ações relacionadas à manutenção do hotel, que comprometem boa parte do faturamento.

Segundo o gerente, todos os meses, são realizadas reuniões na empresa para se discutir o plano estratégico. Junto com as chefias a gerência geral discute algumas idéias e são determinadas as prioridades e sua futura execução. No entanto, os objetivos e metas não são registrados em um documento e não são divulgados na empresa. A razão principal é a mudança constante dos objetivos que variam de acordo com as necessidades do hotel.

A título de ilustração o gerente citou um exemplo de decisão estratégica: "há nove anos mudamos a cara do hotel", saímos da exclusividade do termalismo (banho de águas sulforosas entre outros tipos) e passamos a atender o segmento de lazer, deixando de priorizar o mercado do idoso e explorando o lazer de final de semana. Existe a visão de longo prazo, mas nada é escrito, o plano está na cabeça do dirigente. Para descrever o plano, o gerente citou dois de seus sonhos: "transformar a fazenda dos proprietários em um ponto turístico do hotel” e lançar as águas quentes de São Pedro, para trabalhar durante o inverno e aumentar a taxa de ocupação do hotel.

A visão externa da empresa é operacionalizada principalmente pela opinião dos hóspedes e pela observação das ações dos concorrentes. O gerente afirma que é importante saber o que os concorrentes estão fazendo antes de tomar decisões. Ele citou também o caso do remédio CATAFLAN que diminuiu o interesse dos turistas pelos banhos de águas sulfurosas, levando o hotel a priorizar outro mercado, o de lazer nos finais de semana. O hotel está preocupado também em identificar o que faz melhor em relação aos seus concorrentes (o atendimento, a diversidade de serviços) e o que está ficando a desejar para melhor atender aos hóspedes (instalações precisando de manutenção, a falta de piscina com água aquecida etc). Na opinião do dirigente, não existe nenhuma dificuldade para se obter as informações necessárias à análise interna e externa do hotel.

\section{b) Especificidades da pequena empresa}

Quanto aos agentes do ambiente que podem influenciar o hotel, o entrevistado citou os concorrentes, os clientes, os fornecedores, o poder público municipal, estadual e federal, os bancos e as entidades de classe. 
O hotel possui três concorrentes direto que possui padrão semelhante de atendimento. Sua desvantagem está nas acomodações (“o hotel ficou quinze anos sem fazer manutenção das suas instalações”). Suas vantagens estão nos preços menores e no melhor atendimento. O gerente vê com bons olhos a instalação de uma rede de hotéis na cidade, pois a cidade seria melhor divulgada e atrairia muito mais turistas, beneficiando a todos os empreendimentos hoteleiros.

Os fornecedores são muitos (regionais) e não oferecem no momento nenhuma ameaça ao hotel. "O poder do fornecedor é relativo, pois nossa atividade é serviço". Os clientes estão cada vez mais negociando os preços pagos pelos serviços. O dirigente afirma que os clientes do hotel têm valorizado mais o preço do que a qualidade; e isto tem atrapalhado o negócio. Para ele o hotel de maior porte tem mais desvantagem quando o assunto é preço, o custo fixo é muito alto; só os funcionários são responsáveis por 85\% desse custo. Para exemplificar, ele contou o caso do seu restaurante, que possui cozinha internacional e estava perdendo os clientes para um restaurante de pequeno porte que ficava a poucos metros do hotel e oferecia a refeição 50\% mais barata. Falou também de algumas escolas de São Paulo, que sempre fecharam pacotes com o hotel e que esse ano mudaram de estabelecimento por causa do preço, ignorando a qualidade do seu serviço.

Quanto às forças do macroambiente, inicialmente foi falado sobre a situação econômica atual do país. O gerente acredita que "hotelaria é supérfluo" e, por isso, é um item facilmente "cortado" do orçamento quando a situação econômica do país piora e diminui a renda do cliente. Ele explicou ainda que "o turismo interno é caro" e isso faz com que qualquer variação negativa na economia prejudique ainda mais as empresas hoteleiras.

Quanto à política fiscal, o gerente acredita que os impostos têm onerado em demasia os negócios. O ISS passou de $2 \%$ para $5 \%$. De forma geral, quando se refere às ações do poder público, faz algumas ressalvas: "temos problemas de acesso à cidade, as estradas não estão em boas condições, falta investimento e apoio para solucionar o problema". Falou também da política municipal de turismo que é voltada para a realização de festas. Quando as festas são locais ou regionais, e só atrai pessoas das cidades próximas, não é bom para a hotelaria. É preciso criar festas que atraiam turistas de Jundiaí, São Paulo, Campinas etc, como é a festa de carros antigos. 
A empresa não participa de nenhuma associação de classe. Para o entrevistado, há uma grande dificuldade em unir os empresários. Nem COMTUR a cidade possui. No entanto, ele tem consciência que sozinho não consegue minimizar a influência das forças do macroambiente que dificultam o bom desempenho do hotel.

Quanto às características estruturais típicas, o hotel possui um gerente geral e 11 chefes atuando no nível administrativo, e mais 44 funcionários para as operações do dia-adia. As atribuições dos funcionários são formalizadas (os procedimentos para realização das tarefas são estabelecidos e escritos) e todos recebem o manual de instruções e passam por treinamento antes de ocuparem o cargo. Das pessoas que ocupam cargos administrativos, o gerente geral é contador há mais de 30 anos no setor hoteleiro, dois dos chefes são pósgraduados em hotelaria e outro possui curso superior.

A autoridade é distribuída em níveis hierárquicos, conforme é demonstrado no organograma da empresa (figura 29, p.84). Os investimentos de grande porte são propostos pelo gerente e decididos pela diretoria. As contratações de funcionários são realizadas pelo gerente (com base nos requisitos do cargo) e a diretoria não interfere. A comunicação acontece predominantemente de duas formas: por escrito são transmitidas às ordens de serviços e oralmente são realizadas reuniões com as chefias para elaborar o plano estratégico, analisar o trabalho realizado e discutir as pesquisas dos clientes entre outros assuntos.

Quanto às especificidades comportamentais do dirigente, o gerente entrevistado citou como importante para quem dirige a empresa duas características principais: amizade e companheirismo.

$\mathrm{Na}$ sua opinião o dirigente precisa adquirir conhecimentos e habilidades relacionados: a hotelaria, finanças, gestão de pessoas e de administração empresarial, para que consiga compreender a empresa e adquira capacidade de lidar com as pessoas. Para ele a experiência também faz a diferença na gestão do hotel.

O gerente tem uma atitude favorável em relação à aplicação de novas técnicas administrativas e em relação à utilização da tecnologia da informação nas atividades do hotel. Para ele a T.I. possibilita decisões mais rápidas. Para exemplificar mencionou o tempo que se gasta hoje para fazer o fechamento do balanço patrimonial. 
Quanto às especificidades tecnológicas, o hotel utiliza as seguintes tecnologias: telefone, fax, página na internet, computador, canal fechado de televisão, banco de dados e rede de informações. A TV é um canal fechado que presta informações ao hóspede sobre o hotel. O banco de dados é uma fonte de informações que é utilizada para enviar mala direta pelo correio aos clientes. E a rede interna de gerenciamento de informações dá suporte às operações diárias do hotel. Já o site da empresa disponível na internet, é utilizado pelo cliente para cadastrar seus dados, fazer reservas e receber informações sobre os eventos do hotel.

No hotel os funcionários são treinados para utilização dos equipamentos e realização de tarefas específicas (monitores, garçons, caixas de restaurante). Reuniões são realizadas com as chefias e com os funcionários da linha de frente para transmitir a melhor maneira de realização das tarefas, proporcionando o melhor atendimento ao turista, a marca registrada do hotel.

A empresa está sempre procurando conhecer novas tecnologias e buscar inovações; inclusive na utilização de novas técnicas administrativas. "A inovação é o que move o hotel" diz o gerente. "Nós temos oito festas juninas e julinas e eventos exclusivos para a terceira idade (serestas)".

\section{c) Informação estratégica (interna)}

Inicialmente foram identificados os tipos e fontes de informações (figura 38) que o hotel utiliza para diagnosticar seus pontos fortes e seus pontos fracos.

Percebe-se claramente a preocupação em utilizar informações para avaliação da situação financeira da empresa, que é bastante relevante quando se pensa em tomar decisões relativas a investimentos (manutenção da estrutura física do hotel, construção de estacionamento, equipamentos para aquecer a água da piscina etc).

A empresa reconhece a importância da informação para a administração do negócio. Seus benefícios são inúmeros, desde a gestão de preços, vendas, determinação dos veículos de publicidade, até a análise dos retornos e determinação de prioridades para investimentos. Para o gerente, "a velocidade das informações dão o ritmo para a administração e seu dinamismo". Os responsáveis pelo acompanhamento das informações são a gerência geral, 
e os setores de marketing e de hospedagem (reservas e recepção). Segundo o gerente a recepção coleta de forma estruturada as informações dos concorrentes.

\begin{tabular}{|c|c|c|c|c|}
\hline $\begin{array}{l}\text { Atividades } \\
\text { do hotel }\end{array}$ & $\begin{array}{l}\text { Tipos de informação para } \\
\text { analisar recursose } \\
\text { capacidades do hotel no } \\
\text { momento atual }\end{array}$ & $\begin{array}{c}\text { Tipos de informação } \\
\text { para analisar o } \\
\text { desempenho atual do } \\
\text { hotel }\end{array}$ & $\begin{array}{c}\text { Grau de } \\
\text { importância } \\
\text { do tipo de } \\
\text { informação }\end{array}$ & $\begin{array}{c}\text { Fontes de } \\
\text { informação }\end{array}$ \\
\hline $\begin{array}{l}\text { Marketing } \\
\text { (comercial) }\end{array}$ & $\begin{array}{ll}\text { - } & \text { Forma de promoção } \\
\text { - } & \text { Equipe de venda } \\
\text { Preço de venda }\end{array}$ & 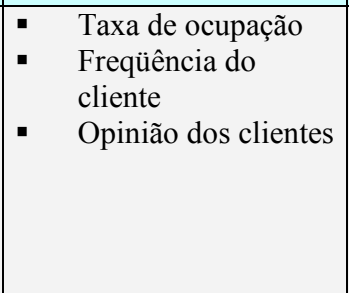 & Importante & $\begin{array}{ll}\text { - } & \text { Ficha do cliente } \\
\text { - } & \text { Equipe de vendas } \\
\text { - } & \text { Rnternet } \\
& \text { Relatório de } \\
\text { - } & \text { Clienterva } \\
& \text { potenciais } \\
\text { - } & \text { Sistema CM }\end{array}$ \\
\hline $\begin{array}{l}\text { Alimentos \& } \\
\text { Bebidas }\end{array}$ & $\begin{array}{l}\text { Custo das mercadorias } \\
\text { - }\end{array}$ & $\begin{array}{ll}\text { - } & \text { Qualidade } \\
\text { - } & \text { Nível de estoque } \\
\text { - } & \text { Opefincõães vendidas dos clientes }\end{array}$ & Importante & $\begin{array}{ll}\text { - } & \text { Funcionários } \\
\text { Observação } & \text { pessoal } \\
\text { - } & \text { Clientes } \\
\text { (questionário) } \\
\text { - } & \text { Mídia }\end{array}$ \\
\hline Hospedagem & $\begin{array}{ll} & \text { Tecnologia de operação } \\
& \text { (procedimentos) } \\
\text { - } & \text { Custos de manutenção } \\
\text { - } & \text { Instalaçãontos }\end{array}$ & $\begin{array}{ll}- & \text { Desperdício } \\
& \text { Opinião dos clientes }\end{array}$ & Importante & $\begin{array}{ll}\text { Funcionários } \\
\text { Observação } \\
\text { pessoal } \\
\text { Clientes } \\
\text { (questionário) }\end{array}$ \\
\hline $\begin{array}{l}\text { Administrativo } \\
\text { (finanças, RH } \\
\text { e outros) }\end{array}$ & $\begin{array}{l}\text { Custos } \\
\text { Competências, } \\
\text { escolaridade, dedicação, } \\
\text { colaboração, integração e } \\
\text { experiência dos } \\
\text { funcionários } \\
\text { Clima organizacional e } \\
\text { relacionamento com os } \\
\text { hóspedes }\end{array}$ & $\begin{array}{|ll|}: & \text { Lucro líquido } \\
\text { - } & \text { Faturamento } \\
\text { - } & \text { Opice de reserva } \\
& \text { produtividadade }\end{array}$ & Importante & $\begin{array}{ll} & \text { Chefias } \\
& \text { Observação } \\
& \text { pessoal } \\
\text { - } & \text { Clientes } \\
& \text { Balanço } \\
& \text { financeiro } \\
\quad & \text { Contador } \\
\text { - } & \text { Sistema CM }\end{array}$ \\
\hline
\end{tabular}

\section{Figura 38 - Dados coletados nas entrevistas (hotel E)}

Fonte: Elaboração própria

Normalmente, as informações relativas ao negócio são coletadas em reuniões com funcionários, pela observação pessoal, por meio do questionário preenchido pelos clientes entre outros. Segundo o dirigente, "os setores selecionam as informações, classificam por assuntos, discutem sua importância com a gerência e arquivam as informações relevantes (em papel - relatórios impressos, disquetes e no computador)". 
Por fim, são tomadas decisões com base nas informações pela gerência geral ou pela diretoria, e depois são apresentadas as implicações dessas decisões aos setores através de reuniões com os funcionários e de conversas informais entre gerente e chefes. 


\section{APÊNDICE E - Análise dos dados}

\section{Hotel A}

O principal dirigente entrevistado é um dos proprietários do hotel e é responsável pela gerência de manutenção, hospedagem e eventos, além de participar da direção geral do hotel.

\section{a) Análise estratégica}

Ao analisar o processo estratégico no hotel pesquisado, observa-se que o caminho escolhido pelos dirigentes para conduzir o negócio não é produto do planejamento formal, contrariando uma das premissas básicas em que se apóia a escola do planejamento (descritas no item 2.1 do capítulo 2).

A estratégia pode ser concebida da reflexão individual de cada dirigente, das conversas informais entre eles, ou ainda das reuniões realizadas para discutir-se o futuro do hotel fazenda. Não existe uma metodologia para ordenar as idéias e ações das pessoas participantes do processo, as alternativas vão surgindo naturalmente a partir da análise dos fatos (dados e informações), e sendo aprovadas pelos membros da sua família. Comprovase, então, que a informalidade do processo de formulação da estratégia é uma especificidade do pequeno empreendimento (figura 15, p.53).

No caso do hotel em questão, esta informalidade é produto da própria crença do dirigente entrevistado da não necessidade de formalizar esta atividade, embora tenha uma atitude favorável à aplicação de novas técnicas administrativas. Na sua opinião, a pouca freqüência com que é realizado o processo estratégico, justifica a sua informalidade. Outros fatores, percebidos durante as entrevistas, que contribuem para que os dirigentes pensem desta maneira, são principalmente: a pequena queda na demanda para hospedagem no hotel, mesmo em período de recessão econômica, e a sua perspectiva de crescimento; a fórmula utilizada até agora tem apresentado bons resultados. Pode-se somar a estes dois fatos, a pouca influência negativa do ambiente nas atividades do empreendimento. O que diminui a exigência de um estudo mais detalhado sobre os fatores que podem ameaçar o crescimento do hotel fazenda. 
Não há dúvidas de que a empresa pensa no futuro e que existe um plano para trilhar o caminho desejado. Mesmo que esteja apenas na mente dos dirigentes, o plano possui um horizonte de longo prazo e é uma referência a ser seguida por todos na empresa. $\mathrm{O}$ foco não é apenas no curto prazo, como foi descrito na figura 15 (p.53), mas também, na preparação do hotel para o futuro. A afirmação do dirigente de que "a visão sobre o futuro da empresa cresce de acordo com o crescimento da conta bancária", comprova o pensamento de longo prazo existente na empresa. Outro sinal de ação futura é a decisão de ampliar o restaurante, para atender não só os hóspedes, mas quem visita o hotel fazenda atraído pelas belezas naturais e pela comida típica.

A elaboração desse plano virtual, muitas vezes acontece durante as reuniões não programadas da diretoria. "Não existe uma data definida para que ocorra, é de acordo com a disponibilidade de tempo dos integrantes da família e das necessidades do hotel", afirma o entrevistado.

Para elaboração do plano, o hotel se preocupa com o que acontece dentro e fora da empresa. A visão externa da empresa se materializa pela constante preocupação dos dirigentes em saber a opinião dos clientes, através de questionários preenchidos na saída do hotel após a prestação do serviço, ou pela página da empresa na internet para receber sugestões. Outras formas utilizadas pelos dirigentes para monitorar o comportamento das forças do ambiente são por meio do acompanhamento do movimento dos concorrentes e pela participação em atividades relacionadas à atividade hoteleira, como as reuniões do COMTUR. Quando o dirigente afirma que a recessão econômica afetou mais os outros hoteleiros, ele comprova a sua preocupação com o ambiente que circunda a empresa. $\mathrm{Ou}$ quando diz que "a prefeitura não atrapalhando, está bom” ele enxerga uma possível ameaça ao seu empreendimento.

A visão interna se materializa quando a diretoria começa a comparar o que o hotel tem de melhor ou pior em relação aos concorrentes. Quando o dirigente afirma que seu preço e a sua estrutura do seu hotel são inferiores ao do principal hotel concorrente, ele está identificando um ponto fraco, que pode comprometer o crescimento tão almejado pelos dirigentes. Isto significa que no hotel pesquisado, existe a preocupação em identificar oportunidades e ameaças e pontos fortes e pontos fracos, que possam colaborar ou comprometer o sucesso do empreendimento, ao contrário das especificidades citadas na 
figura 16. Percebe-se também, que muitas das ações colocadas em prática pelo hotel, são reações às reclamações feitas pelos clientes, o que comprova em parte, um comportamento reativo em relação ao ambiente.

Quanto à disponibilidade de informações para refletir sobre as forças do ambiente e sobre a situação atual da empresa, o hotel possui uma quantidade considerável de informações coletadas de forma desestruturada e que apresenta dificuldade para sua recuperação. Tal fato pode passar uma imagem enganosa de que o hotel é totalmente carente de informações para elaboração do plano estratégico, o que não é verdade. $\mathrm{O}$ problema é muito mais de organização das informações do que de carência de dados e informações. O que comprova a dificuldade da empresa em recuperar as informações no momento oportuno, isto é, na hora da tomada de decisão.

Conclui-se que o hotel fazenda pensa no futuro e possui um plano para alcançar esse estado almejado, embora esteja explícito apenas na memória de seus dirigentes. Este plano é elaborado com base em uma visão interna e externa à empresa e abrange toda a organização, mas não segue nenhuma seqüência de etapas, isto é, as idéias não são orientadas por nenhuma metodologia de planejamento estratégico, as alternativas surgem aleatoriamente durante as conversas entre os dirigentes.

\section{b) Especificidades da pequena empresa}

As especificidades ambientais estão relacionadas ao comportamento das forças que atuam no ambiente operacional e no macroambiente e que podem influenciar positivamente ou negativamente o hotel. Percebe-se pelas entrevistas que o ambiente não tem imposto tantas restrições à atuação da empresa no mercado da hospitalidade. Diferentemente do que se pensava antes da pesquisa de campo.

No ambiente operacional, o hotel interage com os clientes, fornecedores, concorrentes, bancos e entidades de classe. Os clientes mesmo em período de diminuição da renda, como o atual, não deixaram de se hospedar no hotel. Outros, mesmo não se hospedando procuram as atividades ligadas à natureza e a comida típica oferecida pelo hotel fazenda. E ainda têm as empresas que fazem convenções. De forma geral, diminuiu a freqüência da procura, mas a demanda ainda continua satisfatória para as pretensões do hotel. 
Os fornecedores não oferecem nenhuma restrição ao hotel, pois são muitos segundo o dirigente entrevistado. E mesmo assim, "se aumentar o preço do refrigerante, não tem problema, nosso cliente paga sem reclamar", diz o dirigente. Além disso, os gêneros alimentícios consumidos no restaurante (grande parte) são produzidos na própria fazenda.

Quanto aos concorrentes, embora o dirigente afirme que o mercado é competitivo, devido à grande oferta de unidades habitacionais na região, ele acompanha de perto apenas as ações de um dos concorrentes, o que é hotel fazenda e disputa os mesmos segmentos de clientes.

Os bancos servem apenas para guardar os recursos financeiros da empresa. O hotel possui a política de investimento com capital próprio, não recorrendo à pouca disponibilidade de crédito e aos juros excessivos oferecidos pelos bancos. Com outras empresas do setor, o hotel participa de um grupo de 19 empresários que têm como finalidade principal divulgar o turismo de Brotas em feiras realizadas na cidade de São Paulo.

No macroambiente o hotel é influenciado pelas políticas econômicas e fiscais do governo federal e municipal. Sem sombra de dúvida, a inércia da economia tem afetado o empreendimento, mas não compromete, em sua totalidade, os objetivos do hotel. Uma das razões é que o cliente atendido pela empresa não deixou de freqüentar o hotel. Outra razão é a própria capacidade financeira da empresa de resistir a um período de queda na demanda.

Quanto à política fiscal, o dirigente em nenhum momento reclamou da excessiva carga tributária ou da complexidade da legislação por parte do governo federal. A empresa aderiu ao simples, fazendo com que os tributos federais não onerem em demasia os negócios. Sua maior preocupação está na possibilidade da prefeitura inventar alguma novidade e criar algum entrave que possa comprometer o bom andamento do negócio. Seu ceticismo em relação à prefeitura é fruto das reuniões que ele participa no COMTUR, que na sua opinião é uma extensão do paço municipal.

No ambiente operacional, o hotel é mais sensível ao comportamento dos clientes e dos concorrentes. No macroambiente sofre uma influência moderada da economia e das ações da prefeitura municipal, sem comprometer o bom desempenho por duas razões principais: o segmento de mercado que atende e a sua capacidade financeira de suportar a 
diminuição da demanda. Essas influências não diminuem a perspectiva dos dirigentes quanto ao crescimento do empreendimento.

Quanto às especificidades estruturais, basicamente todas as características citadas na revisão bibliográfica foram encontradas no hotel, com exceção do item que relata a mínima preocupação da pequena empresa em contratar pessoas que preencham os requisitos básicos para ocupar um cargo. $\mathrm{Na}$ opinião do dirigente, as pessoas são qualificadas para realizarem as suas tarefas.

O hotel possui poucas unidades de trabalho e os ocupantes dos cargos de nível administrativo possuem muitas atribuições. São responsáveis pelas principais decisões, por sua implementação e pelo controle dos resultados. Por isso, muitas vezes o tempo disponível é escasso para o aprendizado e aplicação de novas técnicas administrativas, como as metodologias de planejamento estratégico e gerenciamento da informação.

A autoridade é centralizada na família e distribuída em dois níveis hierárquicos (figura 25, p.79). As decisões estratégicas são de responsabilidade da família, que também toma decisões no nível operacional (estabelecer procedimentos), mas com a participação dos funcionários que irão executar as tarefas. Outra característica importante da empresa, que foi não citada na revisão teórica é a formalização dos procedimentos para o nível operacional. Esta especificidade facilita o controle de funcionários e dos resultados pelos dirigentes.

A comunicação é, predominantemente oral, com exceção dos procedimentos e seu conteúdo refere-se, basicamente, à distribuição de tarefas.

Quanto às especificidades comportamentais do dirigente, é explicita a atitude favorável do dirigente à utilização de novas técnicas administrativas no seu negócio, diferentemente do que foi constatado na revisão bibliográfica (figura 14, p.50). Uma das razões dessa atitude é o nível de escolaridade dos dirigentes. Outra razão é a experiência positiva que a empresa passou com a implantação de um programa de qualidade que proporcionou uma maior atenção à necessidade de qualificação dos funcionários e um melhor desempenho na realização das tarefas decorrentes da formalização de alguns processos. Outra maneira de ratificar esta atitude é a própria afirmação do entrevistado ao reconhecer a necessidade que todo dirigente tem de aprender conhecimentos e habilidades relacionados à gestão de hotéis, finanças e turismo entre outros, para que seja possível 
entender toda complexidade que envolve a administração de um empreendimento. A receptividade dos dirigentes aos pesquisadores do GEOPE evidencia também a atitude favorável às técnicas administrativas.

Outro ponto positivo no comportamento do dirigente é a aceitação da utilização da tecnologia da informação para desenvolver as atividades do hotel. Essa especificidade contribui para o desenvolvimento de um processo de gestão das informações disponíveis dentro da própria empresa.

Características pessoais como autoconfiança, honestidade, perseverança e vontade de realizar são inerentes ao dirigente entrevistado. Isto se materializa na perspectiva de crescimento da empresa, demonstrando a relação entre as realizações pessoais do dirigente e os objetivos do seu negócio.

Quanto às especificidades tecnológicas, o hotel fazenda está sempre procurando incrementar alguma mudança no atendimento, seja relacionada às técnicas de operação ou aos equipamentos utilizados para prestar o serviço ao cliente. Quando as camareiras participam de treinamento relacionado às atividades dos monitores da área de lazer, para o dirigente esse treinamento produzirá uma inovação no atendimento, pois as camareiras estarão mais bem informadas sobre o funcionamento do hotel e poderão melhor atender às necessidades de informações dos hóspedes sobre as atividades de lazer. Isto permite também uma aproximação maior dos clientes e pode se transformar numa boa fonte de informações. O objetivo da empresa é sempre se aproximar ao máximo do serviço personalizado.

As instalações, equipamentos e processos utilizados pela empresa não apresentam sofisticação como nos grandes hotéis, mas também não são obsoletos como foi citado na revisão bibliográfica. É o caso do centro de convenções do hotel que atende ao mercado empresarial. Seu tamanho é pequeno quando comparado aos grandes hotéis, mas suas instalações são funcionais e aconchegantes e possuem os equipamentos necessários à realização de reuniões, workshops etc. Tecnologia mais simples não significa prestação de serviço de má qualidade.

Com relação à tecnologia da informação, todas as ferramentas utilizadas visam, basicamente, contribuir para a realização e controle das operações do hotel. Essa tecnologia pode ser usada para outras finalidades: como gerenciar informações ou ser um instrumento 
que proporcione vantagem competitiva ao empreendimento. Esta assertiva demonstra mais uma vez as limitações do conhecimento de gestão dos dirigentes do hotel, mas, ao mesmo tempo, percebe-se o esforço deles para suprir essa lacuna: primeiro, ao participar de feiras e eventos do setor turístico com o objetivo de descobrir novas tecnologias e aprender novas técnicas de gestão. Segundo, quando procuram profissionalizar o nível operacional do hotel, principalmente através de treinamento. Por tudo isso, é possível acreditar, na opinião do dirigente, que o hotel tem capacidade de adquirir novos conhecimentos, adequando-os à sua realidade, ou aperfeiçoando esses conhecimentos e habilidades, de forma a manter a competitividade da empresa.

\section{c) Informação estratégica (interna)}

Os dirigentes do hotel têm consciência da importância da informação para o sucesso do negócio. As afirmações do dirigente durante as entrevistas não deixam nenhuma dúvida da relevância da informação. Frases como: vamos ficar no escuro ou sem rumo com a falta de informação evidenciam a sua importância. A empresa carece mais da organização dos dados, principalmente dos financeiros, como foram ditas pelo dirigente.

De maneira informal o hotel realiza as etapas de coleta, processamento e utilização das informações. Com relação ao diagnóstico das reais necessidades dos tipos e fontes de informação úteis ao tomador de decisão, o hotel possui razoável base de dados (figura 31, p.93), sendo necessária uma maior atenção nas informações que irão avaliar o seu desempenho, nas áreas chave do negócio.

Esta etapa de identificação das informações é fundamental para o sucesso do processo de gestão no hotel. Os dirigentes precisam ter em mente que as informações devem proporcionar uma radiografia da situação atual da empresa, de forma a avaliar a quantidade e qualidade de seus recursos, suas habilidades para administrar esses recursos e o seu desempenho passado e atual do hotel. É necessário também, conhecer todas as informações e fontes que estão sendo utilizadas no momento pelos dirigentes do hotel.

Em relação à etapa de coleta dos dados e informações, o hotel apresenta mecanismos manuais e eletrônicos para esta tarefa. A falta de clareza ou a carência de algumas informações não permitem a plena utilização desses instrumentos que são suficientes para a realização desta etapa. 
$\mathrm{Na}$ etapa de processamento, é que o hotel apresenta as maiores dificuldades. As informações estão dispersas e não circulam de forma organizada na empresa, dificultando a sua recuperação pelos tomadores de decisão. $\mathrm{O}$ hotel precisa criar mecanismos que organizem os dados e as informações de acordo com os objetivos do usuário, ou seja, precisa tratar a informação, registrar, apreciar seu conteúdo e elaborar sínteses úteis a quem toma as decisões. Quanto à forma de armazenamento dos dados e informações, não é aconselhável priorizar apenas a memória natural dos dirigentes (as suas mentes), é importante criar uma memória artificial (atas das reuniões, computador etc), que possam arquivar de forma estruturada os dados relativos ao negócio, para que seja possível disponibilizar a informação correta, no formato desejado, à pessoa certa, no momento oportuno.

Com relação à etapa de disseminação, o hotel precisa estudar a melhor forma de apresentar os dados e informações (gráficos, tabelas, quadro de avisos, relatórios simplificados etc) aos tomadores de decisão, que foram definidos nas etapas anteriores do processo de gestão da informação. Percebe-se durante as entrevistas a importância que é dada à transmissão de informações ao nível operacional, após as decisões tomadas pela família. No entanto, não existe preocupação na maneira de apresentar os dados que fundamentam estas decisões de natureza estratégica. Tudo se resume as conversas informais entre os dirigentes. Esta carência fica evidente quando o entrevistado relata a necessidade de organizar as informações do setor financeiro, que para eles são imprescindíveis.

Mesmo de forma desordenada os dirigentes produzem informações e incorporam ao processo decisório ao refletir sobre o futuro do hotel. Quando pensam sobre os concorrentes, ou ouvem e lêem a opinião dos clientes ou quando conversam com seus funcionários eles estão coletando e interpretando dados e produzindo informações que possam ajudar na identificação de suas vantagens e desvantagens competitivas. Quando o dirigente afirma que a capacidade financeira do hotel permite uma maior resistência em períodos de recessão econômica, ele produziu esta informação com base na interpretação de dados e identificou um ponto forte de sua empresa. Mesmo sem uma metodologia, houve a produção de informação e esta é incorporada ao processo decisório do hotel. 
Após a análise dos dados, é possível identificar algumas especificidades do hotel que podem facilitar ou dificultar a melhoria do processo de gestão da informação. $\mathrm{O}$ dirigente do empreendimento tinha apontado algumas características que podem dificultar:

- A informalidade na comunicação e nas relações entre as pessoas dentro do hotel;

- Falta de conhecimento por parte dos funcionários;

- Falta de tempo por parte da diretoria;

- Falta de pessoas qualificadas para implantar o processo de gestão da informação.

Quanto ao primeiro item apontado pelo dirigente, algumas razões minimizam estas dificuldades: a consciência dos dirigentes da importância da informação para a gestão do negócio e a vontade de cumprir os objetivos determinados. O entrevistado está sempre alertando aos dirigentes sobre a importância de alcançar as metas estabelecidas, inclusive sua mãe. Isto não significa que a informalidade das reuniões familiares deva ser abandonada ou colocada em segundo plano. Quanto a segunda dificuldade apontada pelo dirigente, esta será diminuída pela busca constante do hotel em profissionalizar seus funcionários. Para facilitar o processo ou minimizar as dificuldades pode-se acrescentar:

- A atitude favorável dos dirigentes para utilizar novas técnicas de administração;

- A experiência positiva que a empresa passou com a adoção de outra técnica administrativa;

- A sensibilidade do dirigente em reconhecer a necessidade de aprender novos conhecimentos e habilidades para gerenciar o hotel;

- A visão de futuro e a perspectiva de crescimento da empresa;

- A formalização de alguns procedimentos;

- A centralização das decisões estratégicas (a própria adoção do processo de melhoria no gerenciamento da informação é uma decisão estratégica para o hotel);

- O desejo de melhorar sempre o atendimento;

- A utilização da tecnologia da informação nas atividades operacionais do hotel.

\section{Hotel B}

O dirigente entrevistado é o gerente da pousada e é responsável também pelas atividades de marketing e finanças. 


\section{a) Análise estratégica}

Ao analisar o processo estratégico no hotel estudado, é necessário observar a atitude do proprietário e a atitude do gerente em relação ao pensamento futuro do empreendimento. Em ambos os casos o caminho escolhido pelos dirigentes para conduzir o negócio não é produto do planejamento formal, contrariando uma das premissas básicas em que se apóia a escola do planejamento (descritas no item 2.1 do capítulo 2). Cabe ressaltar, mais uma vez, que um dos proprietários toma as decisões relativas a investimentos e contratação de pessoal e o gerente toma as demais decisões que podem afetar o futuro do hotel: estabelecer parcerias, definir a política de preços, desenvolver novos produtos etc.

A estratégia pode ser concebida da reflexão individual de cada dirigente, das conversas informais entre eles, ou ainda como uma reação à opinião dos clientes. Não existe uma metodologia para ordenar as idéias e ações, as alternativas vão surgindo naturalmente a partir da análise dos fatos (dados e informações). Isto comprova que a informalidade do processo de formulação da estratégia é uma especificidade do pequeno empreendimento (figura 15, p.53).

No caso do hotel em questão, esta informalidade é produto principalmente do desconhecimento da técnica administrativa de planejamento estratégico pelos dirigentes. Outros fatores, percebidos durante as entrevistas, que contribuem para que os dirigentes não utilizem uma "metodologia mais sofisticada" são: a crença de que um atendimento diferenciado traz bons resultados; se isto é verdade não tem necessidade do hotel realizar estudo mais detalhado sobre os fatores que podem ameaçar o empreendimento; a despreocupação dos proprietários em obter o retorno do investimento no curto prazo; e a manutenção da sua perspectiva de crescimento, baseada nos resultados apresentados.

Não há dúvidas que o proprietário pensa no futuro e que existe um plano para trilhar o caminho desejado. Os próprios funcionários afirmam que desde o início das atividades o proprietário tem a idéia de expansão do hotel. Mesmo que esteja apenas na sua cabeça. Dessa forma, o foco não é apenas no curto prazo, como foi descrito na figura 16, mas também, na preparação do hotel para o futuro. Até mesmo o gerente que tem um comportamento reativo às ações do ambiente pensa no futuro ao afirmar que "espera vivenciar o crescimento do hotel". 
Mesmo o plano sendo virtual, a direção se preocupa com o que acontece dentro e fora da empresa. A visão externa à empresa materializa-se pela constante preocupação dos dirigentes em saber a opinião dos clientes, através de questionários preenchidos e conversas informais durante e após a prestação do serviço; pela página da empresa na internet para receber sugestões; pelo acompanhamento das ações dos concorrentes etc. Quando o gerente afirma que tem que ficar de orelha em pé com os acontecimentos fora da pousada, ele comprova a sua preocupação com o ambiente que circunda a empresa.

A visão interna se materializa quando a diretoria começa a comparar o que o hotel tem de melhor ou pior em relação aos concorrentes. Quando o dirigente afirma que sua localização é melhor ou que seu hotel oferece mais liberdade ao hóspede em relação aos concorrentes, ele está identificando um ponto forte, que pode contribuir para o crescimento do empreendimento.

Isto significa que, no hotel pesquisado, existe a preocupação em identificar oportunidades e ameaças e pontos fortes e pontos fracos, que possam colaborar ou comprometer o sucesso do empreendimento, ao contrário das especificidades citadas na figura 15 (p.53).

Quanto à disponibilidade de informações para refletir sobre as forças do ambiente e sobre a situação atual da empresa, o hotel possui algumas informações coletadas de forma desestruturada e que apresentam dificuldades para sua recuperação.

Pode-se dizer que o hotel pensa no futuro e possui um plano para alcançar o objetivo almejado, embora esteja explicito apenas na memória dos dirigentes. Este plano é concebido com base em uma visão interna e externa à empresa, mas não segue nenhuma metodologia de planejamento estratégico; as alternativas surgem espontaneamente das reflexões de cada dirigente e das conversas entre eles.

\section{b) Especificidades da pequena empresa}

As especificidades ambientais estão relacionadas ao comportamento das forças que atuam no ambiente operacional e no macroambiente e que podem influenciar, positivamente ou negativamente, o hotel. Percebe-se pelas entrevistas que o ambiente tem imposto moderadas restrições à atuação da empresa no mercado da hospitalidade. Diferentemente do que se pensava antes da pesquisa de campo. 
No ambiente operacional o hotel interage principalmente com os clientes, fornecedores e concorrentes. Os clientes mesmo em período de desaceleração da economia e diminuição da renda, como o atual, não deixaram de se hospedar no hotel. De maneira geral, diminuiu a freqüência da procura, mas a demanda ainda continua satisfatória para as pretensões do hotel. "As finanças da empresa continuam em dia”, diz o gerente.

Os fornecedores não oferecem nenhuma restrição ao hotel, pois são muitos e o mercado é concorrido, afirma o dirigente. Quanto aos concorrentes, o gerente acompanha de perto as suas ações, embora considere a concorrência não prejudicial e acredite que nenhum hoteleiro é capaz de prejudicar o outro. Cada empresa deve apresentar as vantagens do seu produto e atrair os clientes. Na baixa temporada, existe uma grande oferta de unidades habitacionais na região, e o preço da diária diminui e mesmo assim o cliente quer negociar. Na alta temporada, os preços sobem e ainda faltam chalés para atender a demanda. Prevalece a lei da oferta e da procura.

No macroambiente, o hotel é influenciado pelas ações dos governos. A paralisia da economia tem afetado o empreendimento, mas não compromete em sua totalidade os objetivos do hotel. Uma das razões é que o cliente atendido pela empresa diminuiu a freqüência, mas não deixou de se hospedar na pousada. Outra razão é a própria capacidade financeira da empresa de resistir a um período de queda na demanda. Uma terceira razão é a despreocupação dos proprietários na recuperação imediata dos investimentos. O objetivo atual é atender bem e conseguir o retorno financeiro no longo prazo com a fidelidade dos clientes.

Em relação à política tributária do município, o dirigente afirma que só beneficia os empreendimentos ilegais que não pagam os impostos. A alíquota do ISS é alta e não se enxerga os benefícios da aplicação dos recursos. "A cidade não tem nem sinalização turística adequada", diz o gerente.

O hotel não participa das reuniões do COMTUR e de nenhuma entidade de classe, pois acredita que servem apenas para formar "panelinhas" e não contribui para o desenvolvimento do turismo local.

No ambiente operacional o hotel é mais sensível às ações dos clientes e dos concorrentes. No macroambiente sofre uma influência moderada da economia e das ações 
da prefeitura municipal. Mas até o momento essas influências não apresentam nenhum indício que diminua o otimismo dos dirigentes quanto ao sucesso do empreendimento.

Quanto às especificidades estruturais, todas as características típicas mencionadas na revisão bibliográfica foram encontradas no hotel.

A pousada possui poucas unidades de trabalho e os ocupantes dos cargos de nível administrativo possuem muitas atribuições e realizam atividades do dia-a-dia do hotel (o gerente faz o suco, no café da manhã, em determinadas ocasiões). São responsáveis pelas principais decisões, por sua implementação e pelo controle dos resultados. Por isso, muitas vezes o tempo disponível é escasso para o aprendizado e aplicação de novas técnicas administrativas (metodologia de planejamento estratégico e gestão da informação).

A autoridade é distribuída em dois níveis hierárquicos (figura 26, p.81). As decisões estratégicas não relacionadas a investimentos e contratação de pessoal são de responsabilidade do gerente, que também toma decisões no nível operacional (estabelecer procedimentos não formalizados), mas com a participação dos funcionários que irão executar as tarefas. Outra característica importante da empresa, que foi citada na revisão teórica é, a não existência de regulamento de atribuições e nem checklist das tarefas que serão realizadas. Esta especificidade pode dificultar o controle de funcionários e dos resultados pelo gerente, mesmo as pessoas estando muito próximas umas das outras. A comunicação é predominantemente oral e seu conteúdo refere-se basicamente à distribuição de tarefas.

Outro aspecto que merece destaque é a mínima observância com os requisitos dos cargos, caracterizada pela falta de conhecimento e experiência dos funcionários no setor hoteleiro.

Quanto às especificidades comportamentais do dirigente, é evidente a atitude favorável do gerente à utilização de novas técnicas administrativas na gestão da pousada, diferentemente do que foi constatado na revisão bibliográfica (figura 14, p.50). Uma das razões dessa atitude é a sua vontade de aprender e fazer um bom trabalho à frente do hotel. As próprias características pessoais e a maneira como ele gostaria de ser visto pela sociedade evidenciam esta atitude. Outra razão é o seu nível de escolaridade e a falta de experiência em hotelaria. “Às vezes você tem até iniciativa, mas não sabe como agir, ou 
seja, tem uma idéia, mas não sabe colocar em prática, falta conhecimento", afirma o gerente demonstrando a sua dificuldade para gerir o negócio.

Uma terceira razão que produz uma atitude favorável é a própria afirmação do entrevistado ao reconhecer a necessidade de que todo dirigente tem de aprender conhecimentos e habilidades relacionados à gestão, hotelaria, turismo entre outros, para que seja possível entender toda complexidade que envolve a administração de um empreendimento. Para descrever a sua angústia ele se compara a um vendedor (uma de suas atribuições) e diz: "ser vendedor em uma loja de departamento é diferente de ser vendedor em um hotel". A receptividade dos dirigentes com os pesquisadores do GEOPE também ressalta esta atitude.

Outro aspecto importante no comportamento do dirigente é a aceitação da utilização da tecnologia da informação para desenvolver as atividades do hotel. Essa característica contribui para o desenvolvimento de um processo de gestão das informações disponíveis dentro da própria empresa.

Características pessoais como versatilidade, iniciativa, flexibilidade e a vontade de reconhecimento por parte da sociedade se materializa na perspectiva de crescimento da empresa, demonstrando a relação entre as realizações pessoais do dirigente e os objetivos do negócio.

Quanto às especificidades tecnológicas, na pousada, procura-se uma maneira nova de prestar um atendimento diferenciado. Isto permite uma aproximação maior dos clientes, e pode se transformar numa boa fonte de informações. A meta do hotel é sempre se aproximar da personalização do serviço.

As instalações, equipamentos e processos utilizados pela empresa não apresentam sofisticação como nos grandes hotéis, mas também não são obsoletos como foi citado na revisão bibliográfica. É o caso do centro de convenções, do salão de jogos, da sauna e da piscina da pousada que atende aos hóspedes. Seu tamanho é pequeno quando comparado aos grandes hotéis, mas suas instalações são funcionais e aconchegantes e possui os equipamentos necessários à realização de reuniões e workshops, ao divertimento, a comodidade etc. Tecnologia menos sofisticada não significa prestação de serviço de má qualidade. 
Com relação à tecnologia da informação, todas as ferramentas utilizadas, visam basicamente contribuir para a realização e controle das operações do hotel. Essa tecnologia pode ser usada para outras finalidades: como gerenciar informações ou ser um instrumento que proporcione vantagem competitiva ao empreendimento. Isto demonstra as limitações do conhecimento de gestão do gerente da pousada. Mas, ao mesmo tempo, percebe-se o seu esforço para superar essas dificuldades, participando de alguns cursos e aprendendo novas técnicas de gestão e descobrindo novas tecnologias. Um aspecto negativo que merece destaque é a não realização de treinamento dos funcionários por parte dos dirigentes.

\section{c) Informação estratégica (interna)}

O gerente da pousada tem consciência da importância da informação para o sucesso do negócio. As afirmações do dirigente durante as entrevistas não deixam nenhuma dúvida sobre isso. Expressões como: "temos que ficar de orelha em pé com o que está acontecendo" simboliza o reconhecimento da sua importância. No entanto, percebe-se que o gerente ainda não compreende todos os benefícios que a gestão da informação pode lhe proporcionar, conforme citado na revisão bibliográfica.

De maneira informal o hotel realiza as etapas de coleta, processamento e utilização das informações. Com relação ao diagnóstico das reais necessidades dos tipos e fontes de informação úteis ao tomador de decisão, o hotel possui uma base de dados incompleta (figura 31, p.93), sendo necessário uma maior atenção às informações que irão avaliar o desempenho das áreas chave do negócio.

Esta etapa de identificação das informações é fundamental para o sucesso do processo de gestão no hotel, pois o gerente ainda não tem em mente que as informações devem proporcionar uma radiografia da situação atual da empresa, de forma a avaliar a quantidade e qualidade de seus recursos, suas habilidades para administrar esses recursos e o desempenho passado e atual do hotel. É importante, também, à pousada, diagnosticar todas as informações e fontes que estão sendo utilizadas no momento.

Em relação à etapa de coleta dos dados e informações, o hotel apresenta mecanismos manuais e eletrônicos para esta tarefa. A falta de clareza ou a carência de algumas informações não permitem a plena utilização desses instrumentos que são suficientes para a realização desta etapa. 
A etapa de processamento é uma que apresenta as maiores dificuldades no hotel. As informações estão dispersas e não circulam de maneira organizada (opinião dos clientes, por exemplo) dificultando a sua recuperação pelo tomador de decisão. O hotel precisa criar mecanismos que organizem os dados e as informações de acordo com os objetivos do usuário, ou seja, precisa tratar a informação. Registrar, apreciar seu conteúdo e elaborar sínteses úteis a quem toma as decisões. Isto fica claro quando o gerente afirma que as fichas ficam arquivadas, mas não são usadas para nada, "não são exploradas". Quanto à forma de armazenar os dados e as informações é desaconselhado privilegiar apenas as mentes dos dirigentes, é importante criar uma memória organizacional, que possa arquivar de forma estruturada os dados relativos ao negócio, para que seja possível disponibilizar a informação correta, no formato desejado, à pessoa certa, no momento oportuno.

Com relação à etapa de disseminação, o hotel precisa estudar outras formas de apresentar os dados e informações (gráficos, tabelas, quadro de avisos, relatórios simplificados etc) aos tomadores de decisão, que foram definidos nas etapas anteriores do processo de gestão da informação. Tudo se resume às conversas informais entre os dirigentes. Esta carência evidencia-se quando o gerente afirma: o relatório de receitas e despesas “é feito do meu jeito, mas faço". Ele não conhece outros instrumentos que possam ajudá-lo nesta tarefa.

Mesmo de forma desorganizada, os dirigentes produzem informações e utilizam-nas em decisões sobre o futuro do hotel. Quando observam as ações dos concorrentes, ou lêem e ouvem a opinião dos clientes, ou conversam com seus funcionários, eles estão coletando, tratando dados e produzindo informações que possam ajudar na identificação de seus pontos fortes e de seus pontos fracos. Quando o gerente afirma que a pousada apresenta um bom índice de retorno dos clientes, ele produziu esta informação com base em dados e identificou um ponto forte de sua empresa. Mesmo sem uma metodologia, houve a produção de informação e esta é incorporada ao processo decisório do hotel.

Após a análise dos dados é possível identificar algumas especificidades do hotel que podem facilitar ou dificultar a melhoria do processo de gestão da informação. O gerente do empreendimento identificou duas características que podem dificultar: falta de conhecimento e tempo da gerência; 
Quanto às características apontadas pelo gerente, algumas razões minimizam estas dificuldades: a sua consciência da importância da informação para a gestão do negócio, a sua atitude favorável ao aprendizado de novas técnicas administrativas e a sua vontade de participar do crescimento da pousada. Pode-se acrescentar: a falta de formalização dos procedimentos.

Para facilitar o processo, ou minimizar as dificuldades, pode-se acrescentar:

- A sensibilidade do dirigente em reconhecer a necessidade de aprender novos conhecimentos e habilidades para gerenciar o hotel;

- A visão de futuro e a perspectiva de crescimento da empresa;

- A centralização das decisões estratégicas (a própria adoção do processo de melhoria no gerenciamento da informação é uma decisão estratégica para o hotel);

- O desejo de personalizar o atendimento;

- A disposição em utilizar a tecnologia da informação nas atividades operacionais do hotel.

\section{Hotel C}

A dirigente entrevistada é filha do proprietário do hotel e é responsável pelas atividades de finanças, compras, $\mathrm{A} \& \mathrm{~B}$ e recursos humanos.

\section{a) Análise estratégica}

Ao analisar o processo estratégico no hotel pesquisado, observa-se que o rumo escolhido pela família dirigente, para conduzir o empreendimento, não é produto do planejamento formal, contrariando uma das premissas básicas em que se apóia a escola do planejamento (descritas no item 2.1 do capítulo 2).

A estratégia pode ser concebida da reflexão individual de cada dirigente, das conversas informais entre os familiares, ou ainda das reuniões realizadas entre eles para refletir o futuro da pousada. Não existe nenhuma metodologia para ordenar as idéias e ações das pessoas, as alternativas vão surgindo aleatoriamente a partir da análise dos fatos (dados e informações) e sendo aprovadas pelos membros da família. Isto comprova que a informalidade do processo de formulação da estratégia é uma especificidade do pequeno empreendimento (figura 15,53 ). 
No hotel estudado, esta informalidade é fruto principalmente do desconhecimento de uma forma sistematizada de pensar o futuro do negócio. Quando a palavra estratégia foi falada durante a entrevista, percebeu-se uma atitude de desinteresse pelo assunto por parte da dirigente, embora ela tenha uma opinião favorável ao aprendizado de novas técnicas que a ajudem a administrar melhor o negócio.

A empresa pensa no futuro e tem um plano que está armazenado na memória natural dos dirigentes da pousada. No entanto, este plano é, predominantemente, uma resposta à opinião da clientela, isto é, uma reação ao comportamento das forças ambientais. Os dirigentes não têm a intenção de fazer algo de inovador que proporcione uma vantagem sobre os concorrentes, ou antecipar uma ameaça, ou ainda descobrir uma necessidade não atendida no mercado e oferecer um produto. As palavras da dirigente entrevistada comprovam esse raciocínio: "procuramos atender apenas as necessidades básicas dos clientes. Não estamos preocupadas em criar produtos novos". Ao longo das entrevistas esse comportamento reativo da pousada foi ficando claro, comprovando mais uma das especificidades da pequena empresa citadas na figura 15 (p.53). Mesmo assim, não é possível afirmar que o foco está apenas no curto prazo, pois eles têm um plano e não é para execução imediata, principalmente por causa das restrições financeiras da empresa. Cabe ressaltar, também, que as decisões que a dirigente conceituou como estratégicas, são decisões que irão afetar o hotel como um todo e que seus efeitos serão sentidos também no médio e longo prazos, e, mesmo que essas decisões sejam reações às forças ambientais, elas podem ser consideradas como estratégicas para o hotel pesquisado.

Para imaginar o hotel daqui a alguns anos os dirigentes têm duas preocupações: observar o que acontece dentro e fora da empresa. A visão externa à empresa materializa-se predominantemente, pela constante preocupação da empresa em saber a opinião dos clientes. Outras maneiras empreendidas pela entrevistada são: o acompanhamento do movimento dos concorrentes e a participação em atividades relacionadas à atividade hoteleira, como as reuniões do COMTUR. Quando "a dirigente afirma que atualmente a concorrência é também com outras cidades e os hotéis não lotam mais como antigamente" ela considera a influência do ambiente que circunda a empresa.

A visão interna se materializa quando a direção começa a comparar o que o hotel tem de melhor, ou pior, em relação aos concorrentes. Quando a dirigente afirma que seu 
atendimento é melhor e o valor da sua diária é menor ao do principal hotel concorrente, ela está identificando um ponto forte, que pode ajudá-la no alcance dos objetivos da empresa. Isto significa que, no hotel pesquisado, a prioridade que é dada para identificar pontos fortes e pontos fracos não é a mesma para diagnosticar oportunidades e ameaças que possam colaborar ou comprometer o sucesso do empreendimento.

Quanto à disponibilidade de informações, para refletir-se sobre o caminho a seguir pela empresa, o hotel possui algumas informações coletadas de forma desestruturada e que apresentam dificuldades para sua recuperação.

Pode-se dizer que o dirigente hoteleiro pensa no futuro e tem um plano para alcançar o estado almejado, embora esteja explícito, apenas, em sua memória e seja, predominantemente, uma reação às ações das forças do ambiente. Este plano é elaborado com base em uma visão interna e externa a empresa e afeta toda a organização, mas não segue nenhuma seqüência de etapas, as opções vão surgindo casualmente durante as conversas entre os dirigentes.

\section{b) Especificidades da pequena empresa}

As especificidades ambientais estão relacionadas ao comportamento das forças que atuam no ambiente operacional e no macroambiente e que podem influenciar, positivamente ou negativamente, o hotel. Percebe-se pelas entrevistas que o ambiente tem imposto algumas restrições à atuação da empresa.

No ambiente operacional, o hotel relaciona-se, prioritariamente, com os clientes, fornecedores e concorrentes. Pelas entrevistas, verifica-se a preocupação da dirigente com a diminuição da demanda nos dois segmentos de mercado atendidos pela pousada. Como os recursos financeiros da empresa são limitados, a queda da demanda tem afetado diretamente a execução dos planos.

Os fornecedores são em grande número e não têm dificultado as ações do hotel. Quanto aos concorrentes, a dirigente acompanha de perto as ações de um dos concorrentes e a demanda turística de outras cidades (Bonito/MS, por exemplo) que tem potencial turístico para competir com Brotas. A pousada procura se diferenciar do principal concorrente através do atendimento, do preço acessível e da comodidade. Posiciona-se como um hotel de estilo caseiro, aconchegante, mas sem tecnologia sofisticada. 
Os bancos têm utilidade apenas para guardar os recursos financeiros da empresa. A reclamação da dirigente refere-se a dois aspectos: a política de crédito e juros das instituições bancárias e a carência de agências na cidade de Brotas. O primeiro aspecto é um empecilho aos investimentos e conseqüentemente, limita a execução dos planos do hotel que não tem recursos suficientes. $\mathrm{O}$ segundo aspecto retrata a falta de infra-estrutura bancária à disposição dos hóspedes.

No macroambiente, o hotel é influenciado pelas políticas econômica e fiscal. Aos olhos da dirigente, a inércia da economia é o fator ambiental que mais tem afetado o setor hoteleiro de Brotas e segundo ela, houve uma queda generalizada na demanda e "atrapalhou o negócio", comprometendo os projetos de investimentos da maioria dos hotéis, em especial daqueles que não têm capital próprio ou já tinham contraído empréstimos, como é o caso do hotel C.

Quanto à política fiscal, a dirigente acredita que o negócio é prejudicado pela excessiva carga tributária. A empresa aderiu ao simples, mas continua sentindo o peso dos encargos trabalhistas. Em relação aos impostos municipais, a alíquota do ISS é de 5\% e, também, pesa bastante para as finanças do hotel e influencia a sua política de preços acessíveis. Embora reclame dos tributos do município, a dirigente reconhece o empenho da prefeitura para estabelecer políticas eficazes de atração do turista a Brotas, e este é um dos motivos que a faz participar das reuniões do COMTUR há quatro anos.

No ambiente operacional, o hotel está mais sensível ao comportamento dos concorrentes e dos clientes que diminuiu, consideravelmente, a procura por hospedagem. No macroambiente, recebe mais influência da economia e das ações da prefeitura municipal.

Quanto às especificidades estruturais, na pousada, manifestam-se oito das nove características típicas das pequenas empresas citadas na revisão bibliográfica (figura 13, p.46). A exceção é a preocupação da pequena empresa em contratar pessoas que preencham os requisitos básicos para ocupar um cargo no hotel.

O hotel possui poucas unidades de trabalho e os ocupantes dos cargos de nível administrativo, também, desenvolvem atividades na recepção do hotel em escala de horários. Como os dirigentes possuem várias atribuições e são responsáveis pelas principais decisões, por sua implementação e pelo controle dos resultados, muitas vezes, o tempo 
disponível é escasso para o aprendizado e aplicação de novas técnicas administrativas (metodologia de planejamento estratégico e gestão da informação).

A autoridade é centralizada na família e distribuída em dois níveis hierárquicos (figura 27, p.82). As decisões estratégicas são de responsabilidade da diretora geral e da gerente de finanças, as quais também tomam decisões no nível operacional juntamente com os demais familiares e com a participação dos funcionários que irão executar as tarefas. Apesar da não formalização das atividades (outra característica da pequena empresa), existe facilidade de controle das ações dos funcionários e do desempenho da empresa. A comunicação é predominantemente oral e seu conteúdo refere-se basicamente à distribuição de tarefas.

Quanto às especificidades comportamentais do dirigente, ressalta-se a atitude favorável da dirigente à utilização de novas técnicas administrativas no seu negócio, contrariamente ao que foi constatado na revisão bibliográfica (figura 14, p.50). O ceticismo da dirigente demonstrado durante as entrevistas em relação ao processo estratégico está relacionado à falta de entendimento dos benefícios do processo e não invalida a afirmação acima. Três razões justificam esta atitude favorável ao aprendizado e aplicação de novas técnicas de administração: o nível de escolaridade do dirigente; a sua vontade de fazer pósgraduação em hotelaria; o reconhecimento, por parte da entrevistada, da necessidade que todo dirigente tem de aprender conhecimentos e habilidades relacionados à gestão de hotéis, finanças, turismo entre outros, para que seja possível entender toda complexidade que envolve a administração de um empreendimento; e a receptividade dos dirigentes aos pesquisadores do GEOPE.

A dirigente, também, vê, com bons olhos, a utilização da tecnologia da informação, para desenvolver as atividades do hotel, mas não é ela que responde e-mails e faz planilhas na empresa. As entrevistas mostram uma certa resistência de sua parte em utilizar alguns recursos de T.I. e isto pode dificultar o desenvolvimento de um processo de gestão das informações dentro da própria empresa. Essa resistência fica evidenciada quando ela afirma que não gosta muito de internet.

Quanto às especificidades tecnológicas, não existe, na pousada, a visão de desenvolver um produto ou tecnologia de operação que lhe proporcione uma vantagem sobre os concorrentes, ou que diminua os seus custos e aumente a sua rentabilidade. A 
dirigente afirma que a preocupação é apenas atender as necessidades primárias dos hóspedes, sem a preocupação de criar algum produto ou processo novo. Esta afirmação demonstra que, embora a pousada tenha um plano e queira crescer, esse crescimento depende mais das condições favoráveis do ambiente, do que do esforço da empresa em criar algo de diferente para atrair os clientes. Isto não significa que a empresa não possa ter uma posição diferenciada no mercado, mas é um simbolismo do seu comportamento reagente às forças do ambiente. Este é o caminho escolhido pelos dirigentes para conduzir o negócio. Também, não é contraditório, a dirigente querer aprender novos conhecimentos e habilidades e não ter o desejo de produzir, constantemente, inovações tecnológicas, pois é uma opção da dirigente.

As instalações, equipamentos e processos utilizados pela empresa não apresentam sofisticação como nos hotéis de porte maior, mas também não são obsoletos como foi citado na revisão bibliográfica. É o estilo do hotel. Os dirigentes querem preservar um estilo caseiro e menos impessoal. Tecnologia mais simples, não é, significado de prestação de serviço de má qualidade. Além disso, a pousada sofre restrições de recursos financeiros, impedindo a aquisição de outros equipamentos básicos e necessários ao funcionamento do hotel, como foi mencionado pela própria dirigente durante as entrevistas.

È importante ressaltar, também, que todos os funcionários, de acordo com as suas atribuições, estão capacitados para utilizar os equipamentos disponíveis, realizar as suas tarefas e interagir com os hóspedes. Esta característica sinaliza a preparação dos funcionários para o serviço e a possibilidade de aprendizagem de novas habilidades. E pode ser um instrumento facilitador do aperfeiçoamento do processo de gestão da informação.

Com relação à tecnologia da informação, todas as ferramentas utilizadas têm o intuito de contribuir para a realização das operações do hotel, o que possibilita a sua utilização para outras finalidades: como o gerenciamento das informações internas. Esta hipótese demonstra mais uma vez as limitações do conhecimento de gestão dos dirigentes do hotel, mas, ao mesmo tempo, percebe-se o esforço deles para suprir essa necessidade, ao participar de eventos relacionados ao turismo com o objetivo de aprender novas técnicas de administração. 


\section{c) Informação estratégica (interna)}

Os dirigentes da pousada têm consciência da importância da informação para a administração empreendimento. As afirmações da dirigente durante as entrevistas não deixam nenhuma dúvida da relevância da informação. Frases como: "a informação é a base que possibilita organizar o hotel e dividir as funções" evidenciam a sua importância. Entretanto, a entrevistada não demonstra plena compreensão dos benefícios que a organização dessa informação pode trazer na gestão da pousada.

De maneira pouca estruturada, o hotel realiza as etapas de coleta, processamento e utilização das informações. Com relação ao diagnóstico das reais necessidades dos tipos e fontes de informação úteis ao tomador de decisão, o hotel possui uma base de dados incompleta (figura 31, p.93), necessitando-se de uma maior atenção nas informações que representam os indicadores de desempenho das áreas críticas do negócio.

A etapa de identificação das informações é fundamental para o sucesso do processo de gestão da informação estratégica. Os dirigentes precisam compreender que as informações devem proporcionar uma fotografia da situação atual da empresa, de forma a avaliar a quantidade e qualidade dos recursos, suas habilidades para administrar esses recursos e o desempenho passado e atual do hotel. É preciso também, conhecer todas as informações e fontes que estão sendo utilizadas, no momento, pelos dirigentes do hotel.

Em relação à etapa de coleta dos dados e informações, o hotel apresenta mecanismos manuais e eletrônicos para esta tarefa. A falta de clareza ou a carência de algumas informações não permitem a plena utilização desses instrumentos, que são suficientes, para a realização desta etapa.

$\mathrm{Na}$ etapa de processamento, o hotel demonstra as maiores dificuldades. As informações estão dispersas e não circulam de forma organizada na empresa, dificultando a sua recuperação pelos tomadores de decisão. O hotel precisa tratar a informação, isto é, precisa criar instrumentos que organizem os dados e as informações de acordo com os objetivos do usuário. Quanto à forma de armazenamento dos dados e informações é necessário criar uma memória organizacional (ir além da memória natural dos dirigentes) que possa arquivar de forma estruturada os dados relativos ao negócio, e seja possível disponibilizar a informação correta, no formato desejado, à pessoa certa, no momento oportuno. 
Com relação à etapa de disseminação da informação, a dirigente precisa estudar outras formas para apresentar os dados e informações (gráficos, tabelas, quadro de avisos, relatórios simplificados etc) aos tomadores de decisão, pois as conversas informais são insuficiente para refletir de forma clara a situação atual da empresa, em especial a financeira.

Mesmo de forma pouco estruturada os dirigentes produzem informações e incorporam ao processo decisório ao refletir sobre o futuro do hotel (definição do valor da diária, escolha dos fornecedores). Quando observa os concorrentes, ou ouve a opinião dos clientes e conversa com os funcionários, a dirigente está coletando e interpretando dados e produzindo informações que possam ajudar na identificação de suas vantagens e desvantagens competitivas. Quando a dirigente afirma que a inércia da economia tem atrapalhado o negócio, ela produziu esta informação com base no tratamento dos dados e identificou uma ameaça do ambiente. Mesmo sem uma metodologia, houve a produção de informação e esta é incorporada ao processo decisório da dirigente.

Após a análise dos dados, é possível identificar algumas especificidades do hotel que podem facilitar ou dificultar a melhoria do processo de gestão da informação. A dirigente entrevistada apontou como característica que pode dificultar: a falta de tempo dos familiares. Podem-se acrescentar: a falta de conhecimento por parte dos dirigentes dos benefícios da gestão da informação e a não formalização de alguns procedimentos. Para facilitar o processo ou minimizar as dificuldades, podem ser acrescentadas:

- A consciência dos dirigentes da importância da informação para a gestão do negócio;

- A atitude favorável dos dirigentes para utilizar novas técnicas de administração;

- O reconhecimento por parte da dirigente da necessidade de aprender novos conhecimentos e habilidades para gerenciar a pousada;

- A visão de futuro e a perspectiva de crescimento da empresa;

- A centralização das decisões estratégicas (a própria adoção do processo de melhoria no gerenciamento da informação é uma decisão estratégica para o hotel);

- O desejo de melhorar sempre o atendimento;

- A utilização da tecnologia da informação nas atividades operacionais do hotel. 


\section{Hotel D}

A entrevistada é proprietária e dirigente do hotel e é responsável por toda atividade administrativa (marketing, finanças etc).

a) Análise estratégica

Ao analisar o processo estratégico na pousada pesquisada, observa-se que a estratégia escolhida pela empresária ao direcionar o negócio não é produto do planejamento formal, contrariando uma das premissas básicas em que se apóia a escola do planejamento (descritas no item 2.1 do capítulo 2).

A estratégia pode ser concebida da reflexão individual da dirigente ou das conversas informais com clientes e funcionários. Não existe uma metodologia para ordenar as idéias e ações, as alternativas vão surgindo, naturalmente, a partir da análise dos fatos (dados e informações). Comprovando que a informalidade do processo de formulação da estratégia é uma especificidade da pequena empresa (figura 15, 53).

No caso da pousada, esta informalidade é produto da própria crença da empresária da não necessidade de formalizar esta atividade, embora tenha uma atitude favorável à aplicação de novas técnicas administrativas. Outro fato que contribui para este pensamento é o próprio desempenho da pousada em períodos de diminuição da demanda, caracterizando que o processo utilizado, até agora, traz bons resultados apesar de sua informalidade (a duplicação da pousada nos últimos dois anos com capital próprio). O empreendimento, também, recebe pouca influência negativa do ambiente, o que diminui a exigência de um estudo mais detalhado sobre os fatores que podem ameaçar o alcance dos objetivos.

Não há dúvidas de que a empresária pensa no futuro e que existe um plano para trilhar o caminho desejado. Mesmo que esteja apenas em sua memória natural, o plano possui um horizonte de longo prazo e é uma referência a ser seguida por todos na empresa. O foco não é, apenas, no curto prazo, como foi descrito na figura 15 (p.53), mas também, na preparação do hotel para alcançar a meta estabelecida. A afirmação da empresária de que tudo que é realizado na pousada está dentro da sua visão de futuro, comprova o pensamento de longo prazo existente na empresa. A definição da estratégia é produto da reflexão individual da proprietária. Ela decide o que, como e quando fazer e comunica aos demais funcionários. 
Para a elaborar o plano, a dirigente reflete sobre o que acontece dentro e fora da empresa. A visão externa à empresa se materializa pela constante preocupação da empresária em saber a opinião dos clientes, através de conversas informais, ou pelas críticas e sugestões enviadas pela internet. Quando a dirigente afirma que "quanto maior a concorrência, melhor" ela demonstra a sua preocupação com o ambiente que influencia a pousada.

A visão interna é operacionalizada, quando a empresária começa a comparar o que o hotel tem de melhor ou pior em relação aos concorrentes. Quando ela afirma que tem um diferencial em relação aos grandes concorrentes, por ser a única pousada a fornecer babá e a receber animais de estimação, ela está identificando um ponto forte, que pode contribuir para o alcance dos objetivos da empresa.

Isto significa que, no hotel pesquisado, existe a preocupação em identificar oportunidades e ameaças e pontos fortes e pontos fracos que possam colaborar ou comprometer o sucesso do empreendimento, ao contrário das especificidades citadas na figura 15 (p.53).

Quanto à disponibilidade de informações para refletir sobre as forças do ambiente e sobre a situação atual da empresa, existem algumas informações coletadas de forma desestruturada e apresenta dificuldades para sua recuperação.

Pode-se dizer que a dirigente da pousada reflete sobre o futuro e possui um plano para alcançar esse estado almejado, embora esteja claramente definido apenas na memória da empresária. O plano é concebido com base em uma visão interna e externa à empresa e abrange toda a organização, mas não segue nenhuma metodologia de planejamento estratégico, e as alternativas surgem naturalmente das reflexões da empresária.

\section{b) Especificidades da pequena empresa}

As especificidades ambientais estão relacionadas ao comportamento das forças que atuam no ambiente operacional e no macroambiente. Percebe-se pelas entrevistas que o ambiente não tem imposto tantas restrições à atuação da empresa no mercado da hospitalidade, sendo diferente do que se pensava antes da pesquisa de campo.

No ambiente operacional, a pousada se relaciona principalmente com os clientes, fornecedores e concorrentes. De forma geral, diminuiu a freqüência da procura pela 
pousada, mas a demanda ainda continua satisfatória para as pretensões da dirigente, pois ela aumentou a quantidade de chalés mesmo em tempo de desaceleração da economia. Além do período de baixa temporada, o ano de 2003 teve poucos feriados, contribuindo ainda mais para a diminuição da demanda. Outro fator que ajuda a diminuir a demanda é o próprio segmento de clientes que ela procura atender: as famílias, que normalmente gastam mais.

Os fornecedores não causam nenhuma ameaça ao empreendimento. Eles contribuem para que a pousada alcance os seus objetivos através da qualidade dos alimentos e da negociação facilitada com a empresária. Quanto aos concorrentes, a proprietária afirma que quanto mais, melhor. Durante as entrevistas ela tenta demonstrar que não liga muito para o que a concorrência faz, "dizendo que os hotéis é que tentam imitá-la". Fala também de todas as vantagens que a pousada oferece em relação às demais empresas do setor. No entanto, descreve, detalhadamente, os pontos negativos dos hotéis e pousadas da região, demonstrando que está bem atenta ao que o concorrente faz e procura não cometer os mesmos erros dos outros hotéis.

Os bancos servem apenas para guardar os recursos financeiros da empresa. A empresária reinveste todo o lucro na própria pousada e adota a política de investimento apenas com capital próprio, por causa dos juros excessivos cobrados pelas instituições bancárias.

Do macroambiente a pousada recebe principalmente as influências das ações do poder público. Sem sombra de dúvida, a inércia da economia tem afetado o empreendimento, mas não compromete em sua totalidade as metas estabelecidas pela proprietária. Uma das razões é a manutenção da freqüência de clientes na alta temporada. Outra razão é a própria capacidade financeira da empresa de resistir a um período de queda na demanda, que permitiu que a pousada fosse triplicada nos últimos dois anos.

Em relação aos tributos, a empresária queixa-se apenas dos encargos trabalhistas que se tornam muito altos durante os períodos de baixa temporada, por causa da diminuição da demanda. Quanto ao poder executivo municipal, a empresária acredita que a prefeitura não tem cumprido o seu papel de fomentadora do turismo, mesmo após o plebiscito realizado na cidade que aprovou a priorização do turismo como atividade econômica do município. Além disso, não faz nenhuma campanha pelo turismo sustentável. 
Em relação às instituições de ensino, a empresária vê com certo ceticismo o que se ensina nos bancos escolares. Todas as experiências que ela relatou não foram muito animadoras. Primeiro, com o seu filho que fez um curso de hotelaria que prepara mão-deobra para hotéis internacionais. Depois, com as estagiárias de Piracicaba, habilitadas a trabalharem em hotéis de grande porte. O resultado dessa experiência para a empresária é demonstrado na seguinte afirmação: as pessoas são mais qualificadas pelo treinamento do dia-a-dia (convivência) do que pelos cursos que possuem. Isto caracteriza uma das especificidades citadas na revisão bibliográfica a de que a pequena empresa é empregadora de administradores deslocados, isto é, de pessoas preparadas para trabalharem em grandes empresas. Esta experiência pode, também, gerar resistência por parte da dirigente em aceitar a aplicação de novas técnicas administrativas. Mesmo ela afirmando que é favorável à sua utilização, desde que adequada à realidade do seu empreendimento.

No ambiente operacional o hotel é mais sensível ao comportamento dos clientes e dos concorrentes. No macroambiente sofre uma influência moderada da economia e das ações da prefeitura municipal, sem comprometer totalmente o desempenho diante das circunstâncias apresentadas.

Quanto às especificidades estruturais, oito de nove características das pequenas empresas citadas na revisão bibliográfica foram encontradas na pousada. A exceção é a preocupação da pequena empresa em contratar pessoas que preencham os requisitos básicos para ocupar um cargo. Na opinião da proprietária, todos os funcionários da pousada são qualificados para realizarem as suas tarefas.

O hotel possui apenas uma unidade administrativa e mais seis funcionários para realizarem as tarefas do dia-a-dia. A dirigente é responsável pelas atividades administrativas e principais decisões, por sua implementação e controle dos resultados. Seu tempo disponível é escasso e dificulta o aprendizado e aplicação de novas técnicas administrativas (metodologia de planejamento estratégico e gestão da informação). Para facilitar, ainda mais, o controle do hotel, estão sendo criados alguns procedimentos para realização das tarefas pelos funcionários, uma característica que não é comum nas pequenas empresas.

A autoridade é centralizada na empresária e distribuída em apenas um nível hierárquico (figura 28, p.83). As decisões estratégicas são de responsabilidade da dirigente, 
que também toma decisões no nível operacional (estabelecer procedimentos), mas com a participação dos funcionários que irão executar as tarefas. A comunicação com funcionários é predominantemente oral e seu conteúdo refere-se, basicamente, à distribuição de tarefas. Da mesma maneira informal é a comunicação com os hóspedes da pousada.

Quanto às especificidades comportamentais do dirigente, a empresária afirma ter uma atitude favorável à utilização de novas técnicas administrativas no seu negócio e reconhece a necessidade de aprender novos conhecimentos e habilidades sobre gestão hoteleira, embora durante as entrevistas, perceba-se uma certa resistência de sua parte, por algumas razões: a experiência que a pousada passou com o filho da empresária e com estagiários da cidade de Piracicaba; a experiência da dirigente como proprietária de lojas de roupas e calçados; a triplicação da pousada, um sinal de sucesso, mesmo em tempos difíceis e a sua maneira de responder às perguntas dos pesquisadores do GEOPE, apresentando sempre os pontos positivos do seu empreendimento. $\mathrm{O}$ único ponto negativo citado durante as entrevistas foi a carência de informações financeiras e por lapso do contador.

Um ponto positivo para o desenvolvimento de um processo de gestão das informações na empresa é a utilização da tecnologia da informação nas atividades operacionais do hotel.

Características pessoais como: domínio do negócio, confiança para controlar o próprio destino, segurança, motivação e otimismo, demonstram a relação entre as realizações pessoais da empresária e os objetivos do seu negócio. A dirigente é exigente, persistente, determinada e busca a perfeição insistentemente. Em vários momentos, ela afirma que o negócio é uma extensão dos seus sonhos pessoais.

Quanto às especificidades tecnológicas, o hotel está sempre procurando incrementar alguma mudança no atendimento. A proprietária gosta de fazer coisas excêntricas: coloca até uma rosa dentro do vaso sanitário para recepcionar os hóspedes. O objetivo da empresa é, sempre, personalizar o atendimento ao turista.

Os funcionários conhecem os equipamentos e as atividades que irão realizar. Recebem treinamento antes de iniciar as tarefas e aprendem a se relacionar com os hóspedes. Isto demonstra a preocupação da dirigente em preparar os funcionários para utilizarem a tecnologia de operação da pousada. Além da atividade técnica, os funcionários 
estão habilitados a prestarem qualquer informação sobre o funcionamento interno da pousada. Uma condição necessária ao contato direto e mais informal que a empresária deseja ter com os hóspedes da pousada, como se fosse uma família.

As instalações, equipamentos e processos utilizados pela pousada não apresentam a sofisticação dos grandes hotéis, mas também não podem ser considerados obsoletos como foi citado na revisão bibliográfica (figura 16, p.55). Sofisticação é o que empresária não deseja. Ela quer criar um ambiente (instalações e equipamentos) que aproxime, ao máximo, os hóspedes da natureza. Sua cozinha tem foco na tradição e nos pratos típicos da vovó. Não é porque a tecnologia é mais simples, que a prestação de serviço deve ser de má qualidade.

Com relação à tecnologia da informação, todas as ferramentas utilizadas, visam basicamente contribuir para a realização e controle das operações do hotel. Essa tecnologia pode também ser usada para outras finalidades: como o gerenciamento das informações disponíveis internamente. Isto demonstra as limitações do conhecimento de gestão da proprietária da pousada.

\section{c) Informação estratégica (interna)}

A dirigente da pousada tem consciência da importância da informação para o sucesso do seu negócio. As suas afirmações durante as entrevistas não deixam nenhuma dúvida da relevância da informação para a gestão do negócio. Afirmações como: "Sem a informação não é possível conduzir o negócio”, fica muito difícil continuar na direção do objetivo, ou "eu busco informação por causa do negócio, se não fosse isso, eu queria viver só a natureza" evidenciam a sua importância. A empresa carece mais da organização dos dados, principalmente dos financeiros, como foi relatado pela própria empresária.

De maneira informal a dirigente da pousada realiza as etapas de coleta, processamento e utilização das informações. Com relação ao diagnóstico das reais necessidades dos tipos e fontes de informação úteis ao tomador de decisão, a pousada possui uma base de dados incompleta, carecendo de maior atenção às informações que irão avaliar o desempenho das áreas principais do negócio.

Esta etapa de identificação das informações é fundamental para o sucesso do processo de gestão da informação na pousada. A empresária precisa se conscientizar 
também, que a organização dos dados coletados devem proporcionar uma radiografia da situação atual da empresa, de forma a avaliar a quantidade e qualidade de seus recursos, as habilidades dos funcionários para administrar esses recursos e o desempenho no passado e no presente do hotel. É necessário também, conhecer todas as informações e fontes que estão sendo utilizadas, no momento, pela dirigente da pousada.

Em relação à etapa de coleta dos dados e informações, a pousada apresenta mecanismos manuais e eletrônicos para esta tarefa. A falta de clareza ou a carência de algumas informações é que dificultam a plena utilização desses instrumentos que são suficientes para a realização desta etapa.

A etapa de processamento representa a maior dificuldade para a empresária, pois os dados estão dispersos e não circulam de forma organizada na empresa, dificultando a sua recuperação na hora da tomada de decisão. A empresa necessita criar mecanismos que organizem os dados e as informações de acordo com os objetivos da empresária, isto é, precisa tratar esses dados, registrar, apreciar seu conteúdo e elaborar sínteses úteis a quem toma as decisões.

Em relação ao armazenamento dos dados e informações, a empresária afirma que a recuperação das informações é realizada por meio da consulta as fichas dos clientes e ao programa HÁBIL (informações financeiras). No entanto, percebe-se durante as entrevistas, que a forma predominante para armazenar dados é a memória natural da empresária. Muitas vezes, foi perguntado que tipo de informação o programa HÁBIL lhe fornecia, e a resposta era sempre a mesma: "tudo o que eu preciso", e não era citado nenhum exemplo. A própria afirmação da proprietária de que a construção dos últimos dois chalés foi "sem muita análise financeira" reforça esse ponto de vista. Dessa forma, a dirigente precisa criar uma memória organizacional, que possa arquivar de forma estruturada os dados relativos ao negócio e seja possível a sua utilização no processo decisório.

Com relação à etapa de disseminação, a dirigente precisa estudar a melhor forma de visualizar os dados e informações em gráficos, tabelas, relatórios simplificados etc, que serão úteis as suas próprias decisões e que foram definidos nas etapas anteriores do processo de gestão da informação, em especial as informações da área financeira, apontada pela empresária como uma deficiência. 
Mesmo de forma desordenada, a empresária produz informações e incorpora ao processo decisório ao refletir sobre o futuro do hotel. Quando observa os pontos negativos dos concorrentes, ou ouve e lê a opinião dos clientes, ou quando conversa com seus funcionários, ela está coletando e interpretando dados e produzindo informações que possam ajudar na identificação de seus pontos positivos e negativos em relação aos outros empreendimentos hoteleiros. Quando o dirigente afirma que tem um diferencial em relação aos grandes hotéis, ela produziu esta informação com base na interpretação de dados e identificou um ponto forte de sua empresa. Mesmo sem uma metodologia, houve a produção de informação e esta é incorporada ao processo decisório do hotel.

Após a análise dos dados, é possível identificar algumas especificidades do empreendimento que podem facilitar ou dificultar a melhoria do processo de gestão da informação. A proprietária da pousada apontou a carência de informações financeiras uma dificuldade ao processo de organização das informações. Pode-se acrescentar a esta lista:

- A resistência da empresária em admitir que a pousada possui um processo de gestão da informação que pode ser melhorado. Isto faria ela reconhecer que é uma limitação da direção, o que não é fácil. Contribui para esta resistência a visão da empresária sobre as instituições de ensino e o próprio sucesso da pousada que foi triplicada num período de dois anos, sinalizando a correção das decisões tomadas pela empresária;

- Falta de tempo da gerência;

- A carência de informações;

Para facilitar o processo ou minimizar as dificuldades podem-se citar:

- A visão de futuro da empresária;

- A idéia de formalizar alguns procedimentos;

- A centralização das decisões estratégicas (a própria adoção do processo de melhoria no gerenciamento da informação é uma decisão estratégica para o hotel);

- O desejo de melhorar sempre o atendimento;

- A utilização do software HÁBIL para registrar alguns dados;

- A utilização da tecnologia da informação nas atividades operacionais do hotel. 


\section{Hotel E}

O dirigente entrevistado é gerente geral no hotel e tem como atribuições: determinar as prioridades operacionais e os investimentos do hotel e encaminhar à diretoria; dar suporte e resolver os problemas encaminhados pelas chefias; relacionar-se socialmente com os hóspedes e administrar as operações e as finanças do hotel.

\section{a) Análise estratégica}

Ao analisar o processo estratégico no hotel pesquisado, observa-se que o caminho escolhido pelo gerente geral para conduzir o negócio não é produto do planejamento formal, contrariando uma das premissas básicas em que se apóia a escola do planejamento (descritas no item 2.1 do capítulo 2 ).

A estratégia pode ser concebida da reflexão individual do gerente, das conversas informais entre o nível administrativo, ou ainda das reuniões realizadas, mensalmente, com as chefias para discutir o futuro do hotel. Não existe uma metodologia para ordenar as idéias e ações das pessoas participantes do processo, as alternativas vão surgindo naturalmente a partir da análise dos fatos (dados e informações) e sendo aprovadas pela gerência geral. Isto comprova a informalidade do processo de formulação da estratégia, também, em um empreendimento de médio porte.

No caso do hotel em questão, esta informalidade é produto da própria crença do gerente da não necessidade de formalizar esta atividade, embora concorde de que não é o ideal e possua uma atitude favorável à aplicação de novas técnicas administrativas. Na sua opinião, "os objetivos mudam e a formalidade engessa o processo". Outros fatores, percebidos durante as entrevistas que contribuem para que o gerente pense desta maneira, são principalmente: que a forma utilizada até agora tem sido satisfatória e a sobrecarga de trabalho sobre ele que se queixava da necessidade de contratar pelos menos uma secretária para lhe ajudá-lo, mas que o hotel não tinha recursos financeiros suficientes.

Não há dúvidas que a empresa pensa no futuro e que existe um plano para trilhar o caminho desejado, mesmo que esteja apenas na memória dos dirigentes, o plano possui um horizonte de longo prazo e é uma referência a ser seguida por todos na empresa. O foco não é apenas no curto prazo, mas também, na preparação do hotel para o futuro. A descrição de dois dos seus sonhos pelo gerente comprova o pensamento de longo prazo existente na empresa. 
Duas das preocupações consideradas pela empresa para a elaboração do plano são: o monitoramento do que acontece dentro e fora do hotel. A visão externa à empresa se materializa pela constante preocupação dos dirigentes em saber a opinião dos clientes, através de questionários preenchidos na saída do hotel após a prestação do serviço, de conversas informais ou pela página da empresa na internet, para receber sugestões. Outras formas utilizadas pelos dirigentes para monitorar o comportamento das forças do ambiente são por meio do acompanhamento do movimento dos concorrentes e pela leitura de revistas, jornais etc. Quando o dirigente afirma que o remédio CATAFLAN levou o hotel a priorizar outro mercado, ele comprova a sua preocupação com o ambiente que circunda a empresa.

A visão interna se materializa quando a diretoria começa a comparar o que o hotel tem de melhor ou pior em relação aos concorrentes. Quando o gerente afirma que a qualidade do atendimento é a "marca registrada" do seu hotel, ele está identificando um ponto forte, que o diferencia dos principais concorrentes e pode contribuir para o alcance dos objetivos organizacionais. Outro fato que comprova a análise interna no hotel é a preocupação do gerente com a qualidade e quantidade dos recursos da empresa.

Isto significa que, no hotel pesquisado, existe a preocupação em identificar oportunidades e ameaças e pontos fortes e pontos fracos que possam colaborar ou comprometer o sucesso do empreendimento. Percebe-se, também, que algumas das ações colocadas em prática pelo hotel, são para reagir às ações dos concorrentes ou reclamações feitas pelos clientes o que comprova, em parte, um comportamento reativo em relação ao ambiente.

Quanto à disponibilidade de informações para refletir sobre as forças do ambiente e sobre a situação atual da empresa, o hotel possui uma quantidade considerável de informações coletadas de forma parcialmente estruturada.

Conclui-se que o hotel pensa no futuro e possui um plano para alcançar o estado almejado, embora esteja explícito apenas na memória de seus dirigentes. Este plano é elaborado com base em uma visão interna e externa à empresa e abrange toda a organização, mas não segue nenhuma seqüência de etapas, isto é, as idéias não são orientadas por nenhuma metodologia de planejamento estratégico, as alternativas surgem, ao acaso, durante as reuniões entre o gerente geral e os chefes de setores. 
b) Especificidades da pequena empresa

As especificidades ambientais estão relacionadas ao comportamento das forças que atuam no ambiente operacional e no macroambiente e que podem influenciar, positivamente ou negativamente, o hotel. Percebe-se pelas entrevistas que o ambiente tem imposto restrições à atuação da empresa no mercado hoteleiro.

No ambiente operacional, o hotel interage com os clientes, fornecedores e concorrentes. Durante períodos de queda da renda, como o atual, os clientes diminuíram acentuadamente a hospedagem no hotel. "Até nossos clientes tradicionais reduziram a freqüência da hospedagem", disse o gerente. A ocupação durante a semana não chega a $15 \%$ das acomodações disponíveis (alta temporada). O hotel possui restrições financeiras e tem passado por dificuldades nesse período de desaceleração da economia, e segundo o dirigente a luta pela redução de custos é diária. Os custos fixos altos (85\% só da mão-deobra), mais a negociação dos clientes por preço menor, tem restringido a capacidade de investimentos da empresa e comprometido a sua ação futura.

Os fornecedores não têm oferecido nenhuma restrição ao hotel, pois são muitos e o seu poder é relativamente baixo. "Nós somos uma empresa de serviço", diz o dirigente entrevistado para justificar a pouca influência dos fornecedores.

Quanto aos concorrentes, o hotel faz o monitoramento sistemático das ações de três concorrentes diretos. Para o gerente o mercado é pouco competitivo. Na sua opinião, há mercado, o que falta é divulgação. No entanto, o hotel perde clientes para outros concorrentes da região que apresentam preços menores e qualidade inferior ou similar de atendimento.

Os bancos servem apenas para guardar os recursos financeiros da empresa. O hotel possui a política de investimento com capital próprio, não recorrendo a pouca disponibilidade de crédito e aos juros excessivos oferecidos pelos bancos. O hotel já passou por uma experiência negativa ao captar recursos em bancos. Sua margem de lucro que é em média de $15 \%$ era corroída pelos juros bancários.

No macroambiente, o hotel é influenciado pelas ações do poder público. Sem sombra de dúvida, a inércia da economia tem afetado o empreendimento e compromete às ações de longo prazo do hotel. Uma das razões é a migração de alguns clientes atendidos 
pela empresa para o concorrente na busca de preços mais baixos. Outra é a própria capacidade financeira da empresa de resistir a um período de queda na demanda.

A política fiscal promovida pelo município também afeta o hotel. Durante as entrevistas, o dirigente reclamou da excessiva carga tributária, e mencionou o aumento do ISS em mais de $100 \%$. Como o hotel presta serviço, fica evidente o aumento nos custos e conseqüentemente no preço da diária. Como o segmento de mercado que o hotel atende é sensível a preço, a demanda diminui.

Outros fatores que influenciam o negócio e inibem a vinda do turista ao hotel são a falta de infra-estrutura viária para acesso à cidade de Águas de São Pedro e a política de turismo da prefeitura voltada prioritariamente para a realização de festas locais.

Pode-se concluir que, no ambiente operacional, o hotel é mais sensível ao comportamento dos clientes e dos concorrentes. No macroambiente, sofre mais influência da inércia econômica, do aumento de tributos e da política municipal de turismo.

Quanto às especificidades estruturais, algumas das características típicas das pequenas empresas citadas na revisão bibliográfica foram encontradas no hotel: poucos níveis hierárquicos, facilidade de controle, escopo de cargo abrangente da gerência e a existência do contato direto e informal entre: gerente, funcionários e hóspedes. As atividades dos colaboradores são previstas no estatuto do funcionário e todos devem passar por treinamento antes de ocupar o cargo.

A autoridade é distribuída em três níveis hierárquicos (figura 29, p84): diretoria, gerência e chefia. A diretoria aprova as decisões estratégicas que envolvem grandes investimentos e que são propostas pela gerência. $O$ gerente geral é responsável pelas principais decisões, por sua implementação e pelo controle dos resultados. O escopo do seu cargo é amplo e acarreta em algumas dificuldades na gestão do hotel: sobrecarga de trabalho, escassez de tempo para reflexão do futuro do hotel e para o aprendizado e aplicação de novas técnicas administrativas (metodologia de planejamento estratégico e gestão da informação). As restrições financeiras impedem a contratação de um funcionário para auxiliar o gerente. Por outro lado, como o gerente geral também é responsável pela administração das operações e das finanças do hotel, possui um controle excessivo sobre os funcionários. As chefias fornecem informações para as decisões da gerência e ajudam na implementação das decisões e avaliação dos resultados. 
A comunicação no hotel é basicamente em dois sentidos para baixo e para cima. Da gerência para as chefias são transmitidos os objetivos do hotel e o meio para alcançá-los. Já as chefias passam ao nível operacional as ordens de serviços. Para cima são fornecidas informações para avaliação dos resultados e sugestões para melhorar a realização das tarefas. Percebe-se pelo conteúdo da comunicação a centralização nas decisões estratégicas.

Quanto às especificidades comportamentais do dirigente, é evidente a atitude favorável do gerente à utilização de novas técnicas administrativas no negócio. Uma das razões dessa atitude é o seu nível de escolaridade e a experiência dos seus 43 anos de hotel. Uma segunda razão é a atenção dispensada aos pesquisadores e o interesse demonstrado durante as entrevistas. Outra maneira de simbolizar esta atitude é a própria afirmação do entrevistado ao reconhecer a necessidade que todo dirigente tem de aprender conhecimentos e habilidades relacionados à gestão de hotéis, finanças entre outros, para que seja possível entender toda complexidade que envolve a administração de um empreendimento.

Outro ponto positivo no comportamento do dirigente é a aceitação da utilização da tecnologia da informação para desenvolver as atividades do hotel. A empresa utiliza um sistema que gerencia todas as atividades operacionais do hotel. Além disso, fornece algumas informações úteis à gestão administrativa. Essa especificidade contribui para o desenvolvimento de um processo de gestão das informações disponíveis dentro da própria empresa.

Características pessoais como amizade, companheirismo e necessidade de realização são inerentes ao dirigente entrevistado, demonstrando uma relação entre as realizações pessoais do dirigente e as escolhas estratégicas.

Quanto às especificidades tecnológicas, o hotel está sempre procurando incrementar alguma mudança no atendimento, seja relacionada às técnicas de operação ou aos equipamentos utilizados para prestar o serviço ao cliente. Quando o gerente afirma que o atendimento tem que ser uma marca registrada do hotel ele demonstra a preocupação em inovar constantemente diferenciando-se do concorrente. Outro demonstrativo da melhoria incremental é a preocupação com o treinamento dos funcionários para interagir com os hóspedes. Isto possibilita uma aproximação maior dos clientes e pode se transformar numa 
boa fonte de informações. O objetivo do hotel é sempre se aproximar da personalização do serviço.

As instalações, equipamentos e processos utilizados pela empresa não apresentam sofisticação como nos grandes hotéis, mas também não são antiquados. No entanto, suas instalações físicas representam um ponto fraco do empreendimento e é um problema de difícil solução, pois a empresa não tem capacidade financeira suficiente para melhorá-las. O próprio gerente reconheceu que, no aspecto manutenção das instalações, ele só tem condições de reagir e não de prevenir futuros problemas.

Com relação à tecnologia da informação (banco de dados, sistema de gerenciamento das operações etc) todas as ferramentas utilizadas, visam, basicamente, contribuir para a realização e controle das operações do hotel. Embora forneça algumas informações úteis ao plano estratégico, essa tecnologia não tem a finalidade de gerenciar informações estratégicas e ser um instrumento que proporcione vantagem competitiva ao empreendimento. Esta assertiva pode sinalizar duas coisas: limitação do conhecimento de gestão da informação do dirigente do hotel e a existência de um ótimo instrumento facilitador da implantação de uma metodologia de gestão da informação estratégica. Dessa forma, é possível acreditar na capacidade do hotel em adequar novos conhecimentos à sua realidade com o objetivo de tornar a empresa competitiva.

\section{c) Informação estratégica (interna)}

O hotel tem plena consciência da importância da informação para o sucesso do seu negócio. As afirmações do dirigente durante as entrevistas não deixam nenhuma dúvida da relevância da informação. Frases como: a informação é que dá o ritmo e o dinamismo da administração, ou "tudo se baseia em informações, desde a pesquisa de mercado até a tomada de preços dos concorrentes" evidenciam a sua importância. A empresa carece mais da organização dos dados e informações (indicadores não econômicos, por exemplo) para analisar, estrategicamente, as áreas principais do hotel, aspecto que não foi apontado pelo gerente em nenhum momento das entrevistas.

De maneira parcialmente estruturada, o hotel realiza as etapas de coleta, processamento e utilização das informações. Com relação ao diagnóstico das reais necessidades dos tipos e fontes de informação úteis ao tomador de decisão, o hotel possui 
razoável base de dados (figura 31, p.93), sendo necessário enfatizar as informações que irão avaliar o desempenho das áreas chave do negócio.

Esta etapa de identificação das informações é fundamental para o sucesso do processo de gestão da informação. Apesar do dirigente demonstrar que conhece os benefícios da utilização da informação, os outros colaboradores (chefes) também precisam ter em mente que as informações devem proporcionar uma radiografia da situação atual da empresa, de forma a avaliar a quantidade e qualidade de seus recursos, as habilidades para administrar esses recursos e o desempenho passado e atual do hotel. Antes de tudo, é necessário conhecer todas as informações e fontes que estão sendo utilizadas no momento pelos dirigentes do hotel.

O hotel utiliza mecanismos manuais e eletrônicos para coletar dados e informações. Três setores (gerência geral, marketing e recepção) realizam sistematicamente esta tarefa e um deles (recepção) de forma estruturada, quando os dados são relativos à concorrência.

A etapa de processamento é onde o hotel apresenta mais dificuldades. Algumas informações por não terem sido identificadas como estratégicas, continuam dispersas e não circulam de forma organizada na empresa, dificultando a sua recuperação pelos tomadores de decisão. O hotel precisa criar mecanismos que organizem todos os dados e informações consideradas importantes para diagnosticar seus pontos fortes e pontos fracos, isto é, registrar, apreciar o conteúdo e elaborar sínteses sobre essas informações úteis a quem toma as decisões. Os dados e informações relevantes são armazenados em papel (relatórios impressos), disquetes e no disco rígido do computador.

Com relação à etapa de disseminação, os setores do hotel que coletam dados e informações, podem estudar outras formas (gráficos, tabelas etc) de apresentá-los durante as reuniões mensais ou conversas informais entre chefia e gerência.

Mesmo de forma parcialmente estruturada, os dirigentes produzem informações e incorporam-nas ao processo decisório ao refletir sobre o futuro do hotel. Quando acompanham as ações dos concorrentes, ou ouvem e lêem a opinião dos clientes, ou quando conversam com seus funcionários, eles estão coletando e interpretando dados e produzindo informações que possam ajudar na identificação de suas vantagens e desvantagens competitivas. Quando o dirigente afirma que a capacidade financeira do hotel não permite a concretização de alguns objetivos, ele produziu esta informação com base na interpretação 
de dados e identificou um ponto fraco do hotel. Mesmo sem a utilização de uma metodologia previamente estabelecida, houve a produção de informação e esta foi incorporada ao processo decisório do hotel.

Após a análise dos dados é possível identificar algumas especificidades do hotel que podem facilitar ou dificultar a melhoria do processo de gestão da informação. Para facilitar o processo ou minimizar as dificuldades podem-se citar:

- A utilização da T.I. nas atividades operacionais do hotel;

- A realização de forma parcialmente estruturada da coleta de informações;

- A facilidade de obter informações;

- A utilização de um sistema (CM Soluções) de gerenciamento das operações do hotel;

- A visão de futuro da empresa;

- O desejo de melhorar sempre o atendimento;

- A formalização de alguns procedimentos;

- A centralização das decisões estratégicas (a própria adoção do processo de melhoria no gerenciamento da informação é uma decisão estratégica para o hotel);

- O desejo do dirigente em adquirir novos conhecimentos.

Algumas características que podem dificultar são:

- Falta de tempo por parte da gerência geral;

- Falta de recursos financeiros para contratar alguém para ajudar o gerente geral. 